2. To: (Receiving Organization)

Distribution

5. Proj.JProg./Dept./Div.:

PFP

8. Originator Remarks:

This document is being approved for release.
3. From: (Originating Organization) EDNW

6. Design Authority/Design Agent/Cog. Engr.:

A. L. Ramble
4. Related EDT No::

$\mathrm{N} / \mathrm{A}$

7. Purchase Order No.:

$\mathrm{N} / \mathrm{A}$

9. Equip./Component No.:

$\mathrm{N} / \mathrm{A}$

10. System/Bidg./Facility:

PFP

12. Major Assm. Dwg. No.:

$\mathrm{N} / \mathrm{A}$

13. Permit/Permit Application No.:

$\mathrm{N} / \mathrm{A}$

14. Required Response Date: $\mathrm{N} / \mathrm{A}$

15.

DATA TRANSMITTED

\begin{tabular}{|l|l|}
\hline $\begin{array}{l}\text { (A) } \\
\text { lem } \\
\text { No. }\end{array}$ & (B) Documentforawing No. \\
\hline 1 & HNE-4029 \\
\hline & \\
\hline & \\
\hline & \\
\hline & \\
\hline & \\
\hline
\end{tabular}

16.

\begin{tabular}{|c|c|}
\hline Approval Designator (F) & \\
\hline $\begin{array}{c}\text { E, S, Q D OR N/A } \\
\text { (See WHC-CM-3-5, } \\
\text { Sec. 12.7) }\end{array}$ & $\begin{array}{l}\text { 1. Approval } \\
\text { 2. Release } \\
\text { 3. Information }\end{array}$ \\
\hline
\end{tabular}

17.

$\begin{array}{lll}\text { (C) Sheet (D) Rev. } & \text { (E) Title or Description of Data Transmitted }\end{array}$

PFP FSAR Functional, Safety Review Board, and Fluor Daniel Hanford Review Report

(F)

\begin{tabular}{|l|l|}
\hline- & 0 \\
\hline & \\
\hline
\end{tabular}

$+$

\begin{tabular}{|c|c|c|c|}
\hline (F) & (G) & $(\mathrm{H})$ & $(\mathrm{I})$ \\
\hline $\begin{array}{c}\text { Approval } \\
\text { nesig- } \\
\text { nator }\end{array}$ & $\begin{array}{c}\text { Reason } \\
\text { frans- } \\
\text { mittal }\end{array}$ & $\begin{array}{c}\text { Origi- } \\
\text { nator } \\
\text { Dispo- } \\
\text { stion }\end{array}$ & $\begin{array}{c}\text { Receiv- } \\
\text { er } \\
\text { Dispo- } \\
\text { sition }\end{array}$ \\
\hline & 1 & 1 & \\
\hline & & & \\
\hline & & & \\
\hline
\end{tabular}

KEY

Reason for Transmittal (G)
4. Review
5. Post-Review
6. Dist. (Receipt Acknow. Required)

Disposition (H) \& (l)

\begin{tabular}{|ll}
$|c|$ & \multicolumn{2}{|c}{ Disposition $(\mathrm{H})$ \& $(\mathrm{l})$} \\
\hline 1. Approved & 4. Reviewed no/comment \\
2. Approved w/comment & 5. Reviewed w/comment \\
3. Disapproved w/comment & 6. Receipt acknowledged
\end{tabular}
SIGNATUREJDISTRIBUTION

(See Approval Designator tor required signatures)

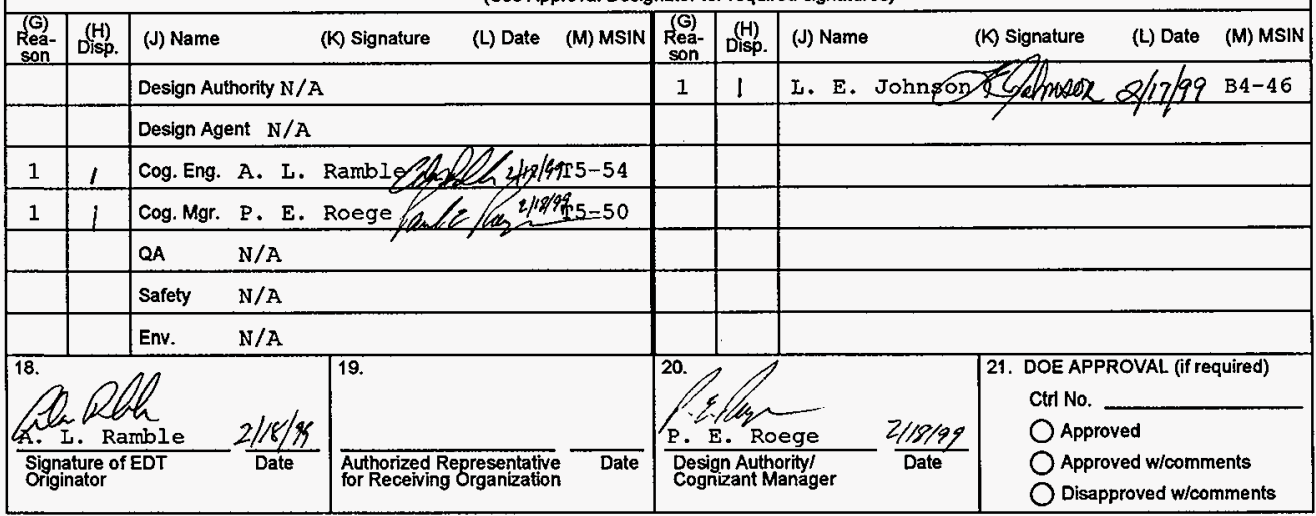




\title{
Plutonium Finishing Plant Final Safety Analysis Report Functional, Safety Review Board, and Fluor Daniel Hanford Review Report
}

I. E. Johnson

Fluor Daniel Northwest, Inc.

Richland, WA 99352

U.S. Department of Energy Contract DE-AC06-96RL13200

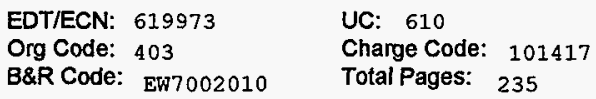

Key Words: PFP Review report, FSAR review, Safety Review Board

\begin{abstract}
This report documents the PFP FSAR, Revision 0, functional, Safety Review Board and Fluor Daniel Hanford review process, including copies of all approved and dispositioned Review Comment Records.
\end{abstract}

TRADEMARK DISCLAIMER. Reference herein to any specific commercial product, process, or service by trade name, trademark, manufacturer, or otherwise, does not necessarily constitute or imply its endorsement, recommendation, or favoring by the United States Government or any agency thereof or its contractors or subcontractors.

Printed in the Unifed States of America. To obtain copies of this document, contact: Document Control Services, P.O. Box 950, Mailstop H6-08, Richland WA 99352, Phone (509) 372-2420; Fax (509) 376-4989.
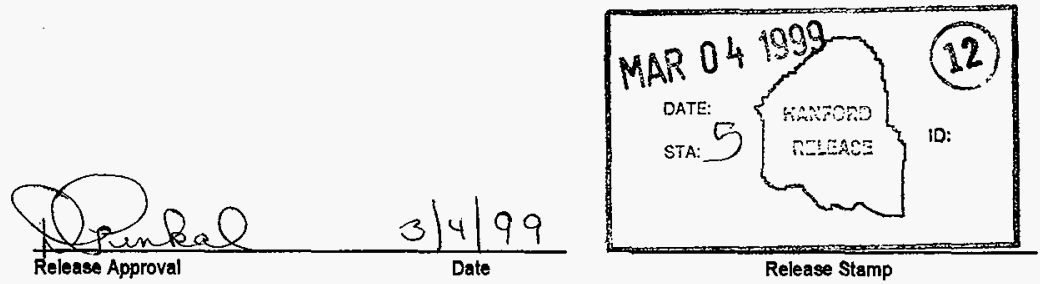

\section{Approved For Public Release}




\section{Plutonium Finishing Plant Final Safety Analysis Report Functional, Safety Review Board, and Fluor Daniel Hanford Review Report}

Prepared by:

Fluor Daniel Northwest

Prepared for:

B\&W Hanford Company

February, 1999 
HNF-4029 Rev. 0

This page intentionally left blank. 


\section{TABLE OF CONTENTS}

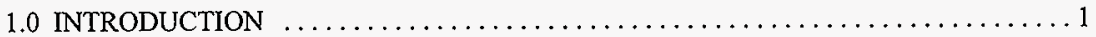

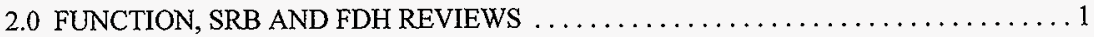

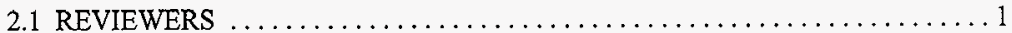

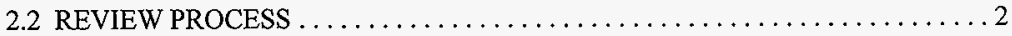

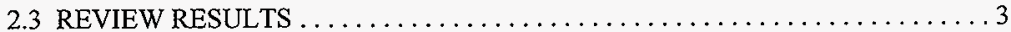

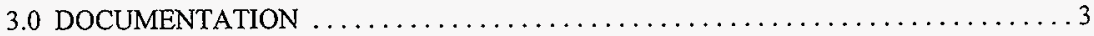

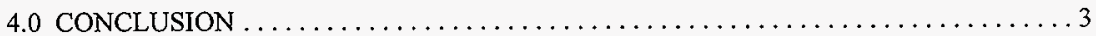

Appendix A PFP FSAR Review Status Report $\ldots \ldots \ldots \ldots \ldots \ldots \ldots \ldots \ldots \ldots \ldots \ldots \ldots \ldots \ldots$

Appendix B Closed Review Comment Records . . . . . . . . . . . . . . . . B-1

Appendix C PFP FSAR Review Schedule $\ldots \ldots \ldots \ldots \ldots \ldots \ldots \ldots \ldots \ldots \ldots \ldots \ldots \ldots \ldots \ldots$ 
HNF-4029 Rev. 0

This page intentionally left blank. 
HNF-4029 Rev. 0

\subsection{INTRODUCTION}

This report documents the completion of the B\&W Hanford Company functional and Safety Review Board reviews and the Fluor Daniel Hanford review for the Plutonium Finishing Plant (PFP) Final Safety Analysis Report (FSAR), HNF-SD-CP-SAR-021, Revision 1. The reviews for the FSAR were conducted during the period from December 9, 1998 to January 14, 1999.

The document was reviewed by cognizant individuals in PFP nuclear safety, quality assurance, plant engineering, operations, the Safety Review Board (SRB) and Fluor Daniel Hanford (FDH). Review comments were recorded on Review Comment Records (RCR) in accordance with current Hanford procedures. Following the review, all comments were dispostioned, approved, and incorporated into the text of the document.

This report details the review process, the reviewers involved, and the final disposition and closure of RCR comments. Appendix A provides the Review Status Report, Appendix B provides copies of the closed RCRs with the RCR signed cover sheet, and Appendix $C$ provides the review schedule.

\subsection{FUNCTION, SRB AND FDH REVIEWS}

\subsection{REVIEWERS}

The following is a list of the reviewers that performed a review of the PFP FSAR. Reviewers were chosen from PFP nuclear safety, quality assurance, plant engineering, plant operations, the Safety Review Board (SRB) and Fluor Daniel Hanford (FDH). This ensured that all organizations required for the document review were adequately represented. All of the reviewers listed below submitted comments during this review:

$\begin{array}{ll}\text { BWHC Reviewers } & \text { Function } \\ \text { AL Ramble } & \text { PFP Facility Engineering } \\ \text { RD Redekopp } & \text { PFP Operations } \\ \text { MD Talbot } & \text { PFP Operations } \\ \text { TA Brown } & \text { PFP Operations } \\ \text { DR Groth } & \text { PFP Quality Assurance } \\ \text { J Bramson } & \text { PFP Environmental } \\ \text { JP King } & \text { PFP Operations } \\ \text { EG Backlund } & \text { PFP Environmental Compliance } \\ \text { RD Keck } & \text { PFP Facility Systems Engineering } \\ \text { HR Risenmay } & \text { PFP Process Engineering } \\ \text { RD Pickett } & \text { PFP Facility Systems Engineering } \\ \text { EW Curfman } & \text { PFP Analytical Labs } \\ \text { WF White } & \text { PFP Facility Systems Engineering } \\ \text { S Zeller } & \text { PFP Quality Assurance }\end{array}$


HNF-4029 Rev. 0

S Zeller

JD Dick

SE Nunn

DA Conners IV
PFP Quality Assurance

PFP Facility Systems Engineering

PFP Nuclear Safety

PFP Nuclear Safety
BWHC SRB Reviewers

CD Wollams

AM Horner

PR Prevo

FDH Reviewers

KK Chitkara

HM Bucci

D Wiatrak

KH Jaten

SC Adams

JA Bates

KA Peterson

DG Ranade

JS Dukelow

FA Ruck

BL Bauman

SM Faulk

BA Williams

JN Nansen
Chairman

Board Member

Board Member

Nuclear Safety

Industrial Safety and Fire Protection

Occupational Health and Safety

Occupational Health and Safety

Environmental Integration

Environmental Integration

Environmental Integration

Environmental Integration

(PNNL)

Environmental Integration

Central Standards Group

Facility Emergency Preparedness

Project Direction/CONOPS

Quality Assurance

\subsection{REVIEW PROCESS}

The functional, SRB and FDH reviews were performed in parallel. Packages were sent out to each designated reviewer and comment submittal was requested per a review schedule (Appendix C). Six packages were delivered to the reviewers in sequence. This process was used as a way to expedite the review process. As individual chapters were completed, they were assembled into a package and transmitted for review. Note that chapter 11, OSRs, was not revised, and therefore, not included in the review. The packages were as follows:

\begin{tabular}{|c|c|c|}
\hline Package & Transmittal date & Chapters \\
\hline$\# 1$ & $12 / 09 / 98$ & $3 \& 12$ \\
\hline \#2 & $12 / 11 / 98$ & $4 \& 10$ \\
\hline \#3 & $12 / 14 / 98$ & $7 \& 8$ \\
\hline$\# 4$ & $12 / 17 / 98$ & 1,5 and $9 *$ \\
\hline$\# 5$ & $12 / 18 / 98$ & $2 \& 9 * *$ \\
\hline$\# 5 \mathrm{a}$ & $12 / 19 / 98$ & 6 \\
\hline
\end{tabular}

* Chapter 9 new analysis sections only

** Complete chapter 9 
The functional, SRB and FDH reviews of the PFP FSAR generated 504 comments. In addition, a significant number of comments were submitted as redline comments on each of the chapter hard copies. All comments submitted under an RCR received individual dispositions and were closed with the reviewer. Once redline text revisions were completed, the chapter lead and reviewer conferred to obtain final RCR approval. Redline markup comment packages were closed by issuing an RCR with a single comment and disposition covering the entire review package, and, if requested, the chapter champion met with the reviewer to ensure satisfactory incorporation of their redline comments. The approved RCRs are included in this report as Appendix B.

\subsection{REVIEW RESULTS}

All comments submitted during the functional, SRB and FDH reviews received acceptable dispositions, appropriate text revisions were prepared and final approval of the changes obtained for each of the reviewers. All RCRs were approved with no outstanding comments with one exception. The RCR by HM Bucci, on chapter 9, comments that "The FSAR is not fully consistent with the PFP FHA as required by HNF-PRO-350." However, it goes on to state that the reviewer recognizes that the time allowed for this update of the FSAR wasn't sufficient to complete a full integration and that some integration steps were satisfactorily completed. It should be noted here that the FSAR did reconcile most of the identified issues between the FSAR and the FHA, and final reconciliation can only be achieved when the FHA is updated.

\subsection{DOCUMENTATION}

All review comments were recorded on RCR forms. When comments were submitted in an electronic file format, they were transferred to an RCR. Comments submitted as a redline mark-up of a hard copy of the FSAR were documented by preparing a RCR with a single comment and disposition noting that a redline markup was submitted and comments were incorporated as appropriate.

\subsection{CONCLUSION}

This report documents the formal functional, SRB and FDH reviews of the PFP FSAR. The 504 review comments were successfully dispositioned and revisions incorporated into the document, as required. The completion of this review report officially documents and closes the PFP FSAR functional, SRB and FDH reviews. 
HNF-4029 Rev. 0

This page intentionally left blank. 
HNF-4029 Rev. 0

Appendix A

PFP FSAR Review Status Report 
HNF-4029 Rev. 0

This page intentionally left blank. 


\section{PFP FSAR Review Status Report}

(January 14, 1998)

\begin{tabular}{|c|c|c|c|c|c|c|}
\hline \multicolumn{7}{|c|}{ Chapter 1} \\
\hline & Name & Comment Package & $\begin{array}{l}\text { Number of } \\
\text { Comments }\end{array}$ & $\begin{array}{c}\text { Date } \\
\text { Received }\end{array}$ & Date Closed & Status \\
\hline 1 & C Wollam & Redline mark-up & - & $12 / 18$ & & 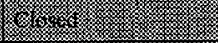 \\
\hline 2 & D Groth & cc:mail comments & 4 & $12 / 18$ & & 3 \\
\hline 3 & R Redekopp & Redline mark-up & - & $12 / 22$ & & 6 \\
\hline 4 & M Talbot & Redline mark-up & - & $12 / 22$ & & \\
\hline 5 & J Bramson & cc:mail ( 1 of 12 comments on chapters $1,5 \& 7$ ) & 1 & $12 / 22$ & & \\
\hline 6 & J King & cc:mail \& RCR & 6 & $12 / 22$ & & \\
\hline 7 & D Wiatrak & cc:mail \& RCR (Ch $1,4,5 \& 10)$ & 2 & $12 / 22$ & & 8 \\
\hline
\end{tabular}

Chapter 2

\begin{tabular}{|c|c|c|c|c|c|c|}
\hline & Name & Comment Package & $\begin{array}{l}\text { Number of } \\
\text { Comments }\end{array}$ & $\begin{array}{c}\text { Date } \\
\text { Received }\end{array}$ & $\begin{array}{c}\text { Date } \\
\text { Closed }\end{array}$ & Status \\
\hline 1 & C Wollam & Redline mark-up & -- & $12 / 18$ & & \\
\hline 2 & K Chitkara & cc:mail \& RCR (Ch 2\&9) & 10 & $12 / 22$ & & (2) \\
\hline
\end{tabular}


Chapter 3

\begin{tabular}{|l|l|l|c|c|c|c|}
\hline & Name & Comment Package & $\begin{array}{c}\text { Number of } \\
\text { Comments }\end{array}$ & $\begin{array}{c}\text { Date } \\
\text { Received }\end{array}$ & $\begin{array}{c}\text { Date } \\
\text { Closed }\end{array}$ \\
\hline 1 & C Wollam & Redline mark-up & - & $12 / 18$ \\
\hline 2 & S Adams & cc:mail \& attached comments & 1 & $12 / 22$ \\
& & & & & \\
\hline 3 & R Redekopp & Redline mark-up (no comments) & 0 & $12 / 21$ & \\
\hline 4 & J King & RCR & & 2 & $12 / 29$ & \\
\hline
\end{tabular}

\section{Chapter 4}

\begin{tabular}{|c|c|c|c|c|c|c|}
\hline & Name & Comment Package & $\begin{array}{l}\text { Number of } \\
\text { Comments }\end{array}$ & $\begin{array}{c}\text { Date } \\
\text { Received }\end{array}$ & $\begin{array}{c}\text { Date } \\
\text { Closed }\end{array}$ & Status \\
\hline 1 & C Wollam & Redline mark-up & - & $12 / 16$ & & \\
\hline 2 & D Groth & cc:mail comments & 7 & $12 / 17$ & & \\
\hline 3 & C Wollam & cc:mail (Ch $4 \&$ 10) & 1 & $12 / 16$ & & \\
\hline 4 & D Groth & cc:mail (general comments) & 1 & $12 / 21$ & & \\
\hline 5 & TA Brown & Redline mark-up & - & $12 / 22$ & ) & \\
\hline 6 & $J$ King & cc:mail \& RCR & 3 & $12 / 22$ & & \\
\hline 7 & D Wiatrak & cc:mail \& RCR & 4 & $12 / 22$ & 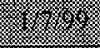 & \\
\hline 8 & R Keck & cc:mail (Ch 4, $7 \&$ \&) & 4 & $12 / ?$ & $\sqrt{2}, 30$ & \\
\hline
\end{tabular}




\section{Chapter 5}

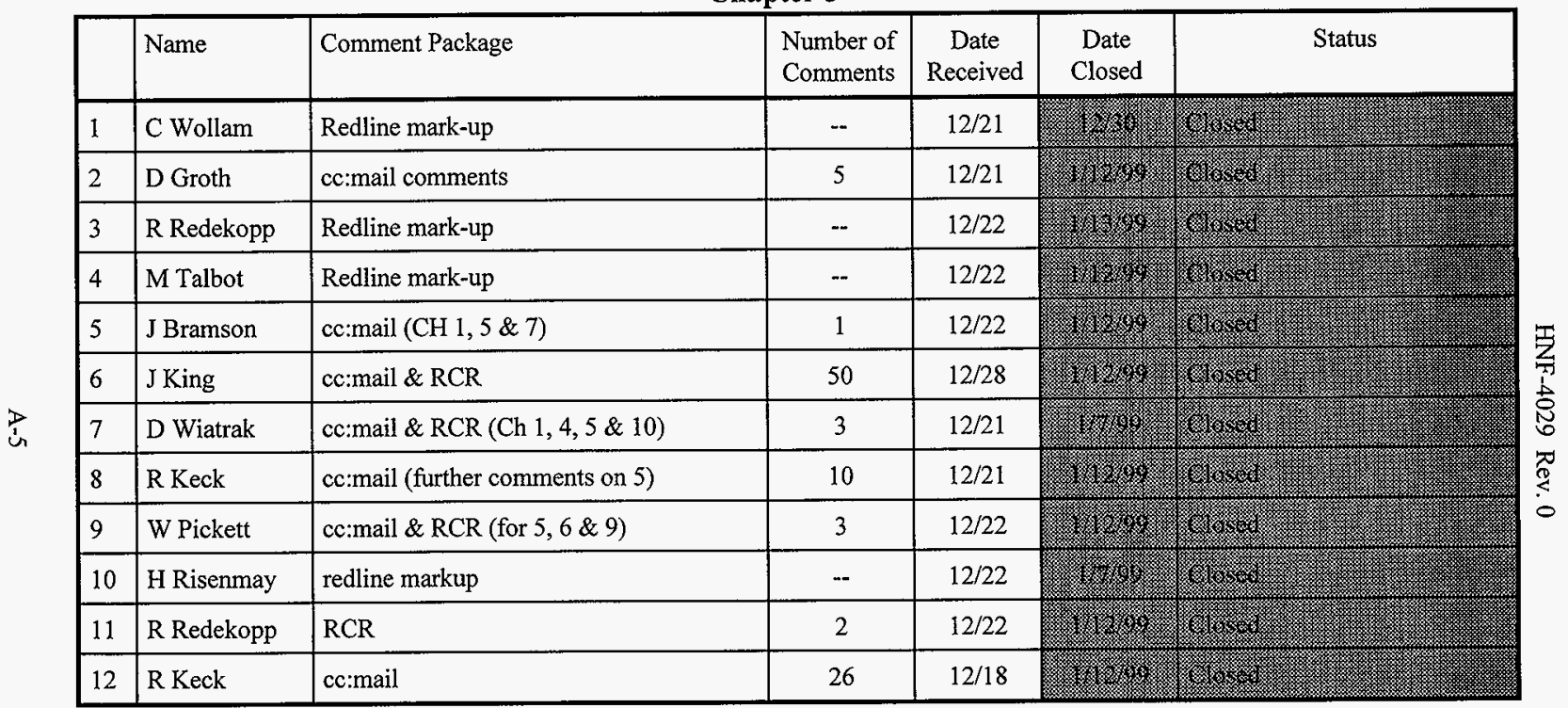


Chapter 6

\begin{tabular}{|c|c|c|c|c|c|c|}
\hline & Name & Comment Package & $\begin{array}{l}\text { Number of } \\
\text { Comments }\end{array}$ & $\begin{array}{c}\text { Date } \\
\text { Received }\end{array}$ & $\begin{array}{c}\text { Date } \\
\text { Closed }\end{array}$ & Status \\
\hline 1 & C Wollam & Redline mark-up & -- & $12 / 22$ & & \\
\hline 2 & D Groth & cc:mail comments & 12 & $12 / 18$ & & \\
\hline 3 & R Redekopp & Redline mark-up & -- & $12 / 22$ & & \\
\hline 4 & TA Brown & Redline mark-up & - & $12 / 22$ & & \\
\hline 5 & H Risenmay & Redline mark-up & -- & $12 / 22$ & & \\
\hline 6 & J King & cc:mail \& RCR & 11 & $12 / 22$ & & \\
\hline 7 & R Pickett & cc:mail \& RCR (Ch 5, 6, \& 9) & 5 & $12 / ?$ & & \\
\hline 8 & C Wollam & cc:mail (additional comments) & 2 & $12 / 22$ & & \\
\hline 9 & EW Curfman & cc:mail & 1 & $1 / 6 / 99$ & & \\
\hline
\end{tabular}

\section{Chapter 7}

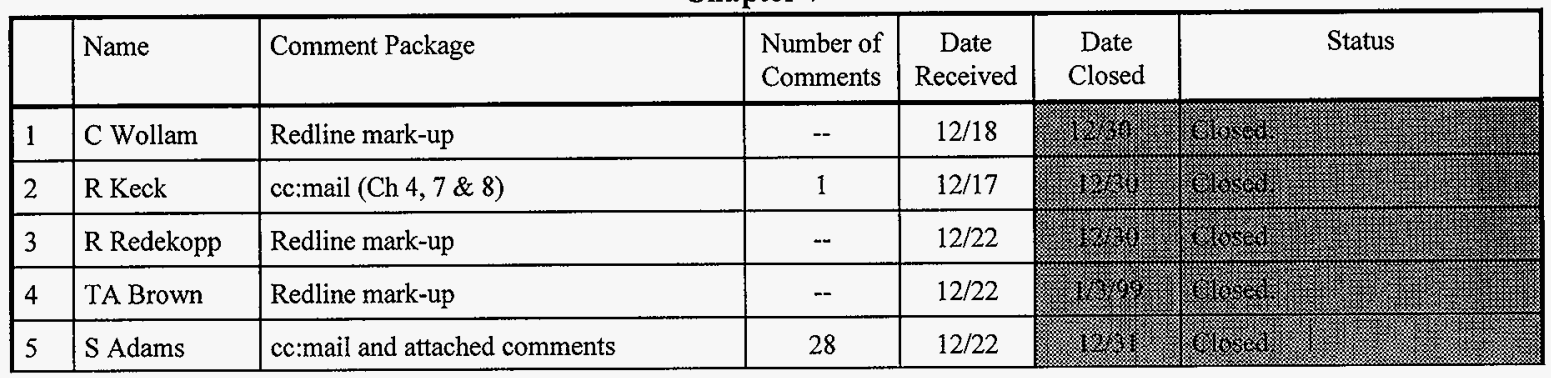




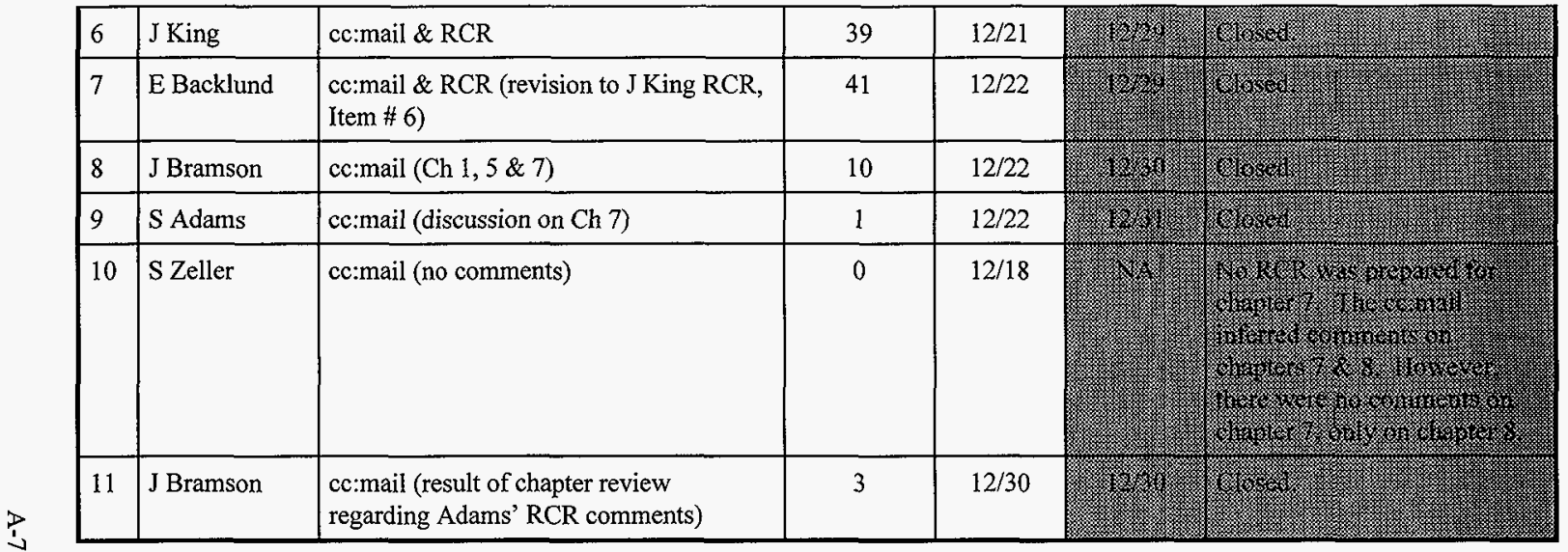

Chapter 8

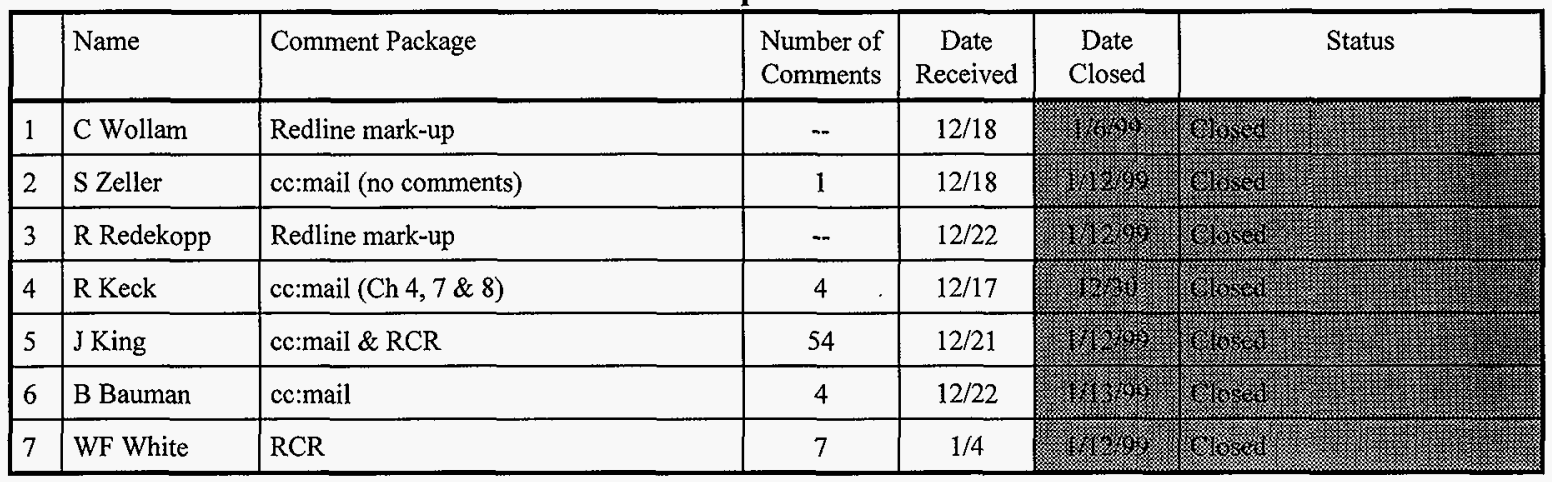




\section{Chapter 9}

\begin{tabular}{|c|c|c|c|c|c|c|}
\hline & Name & Comment Package & $\begin{array}{l}\text { Number of } \\
\text { Comments }\end{array}$ & $\begin{array}{c}\text { Date } \\
\text { Received }\end{array}$ & $\begin{array}{c}\text { Date } \\
\text { Closed }\end{array}$ & Status \\
\hline 1 & C Wollam & Redline mark-up & -- & $12 / 18$ & & \\
\hline 2 & D Groth & cc:mail comments & 4 & $12 / 22$ & & \\
\hline 3 & R Redekopp & Redline mark-up (no comments) & -- & $12 / 22$ & & \\
\hline 4 & M Talbot & Redline mark-up (no comments) & -. & $12 / 22$ & & \\
\hline 5 & H Bucci & $\begin{array}{l}\text { cc:mail \& RCR (and A Ramble Response } \\
\text { on } 12 / 20 \text { ) }\end{array}$ & 7 & $12 / 18$ & & \\
\hline 6 & $\mathrm{~J}$ King & cc:mail \& RCR & 43 & $12 / 22$ & & \\
\hline 7 & P Prevo & cc:mail (Prevo to Wollam to Ramble) & 4 & $12 / 21$ & & 8 \\
\hline 8 & A Horner & cc:mail & 2 & $12 / 22$ & & \\
\hline 9 & J Dukelow & cc:mail \& RCR & 16 & $12 / 22$ & & \\
\hline 10 & H Risenmay & redline mark-up & -- & $12 / 22$ & & \\
\hline 11 & J Dukelow & RCR (second set) & 6 & $12 / 22$ & & \\
\hline 12 & J Dick & cc:mail comments & 1 & $12 / 23$ & & \\
\hline 13 & R Pickett & cc:mail and RCR (Ch 5, 6\& 9) & 5 & $12 / 22$ & & \\
\hline 14 & K Chitkara & cc:mail and RCR (Ch $2 \& 9)$ & 8 & $12 / 22$ & & \\
\hline 15 & H Risenmay & redline mark-up & -- & $1 / 4$ & & $y$ \\
\hline
\end{tabular}


Chapter 10

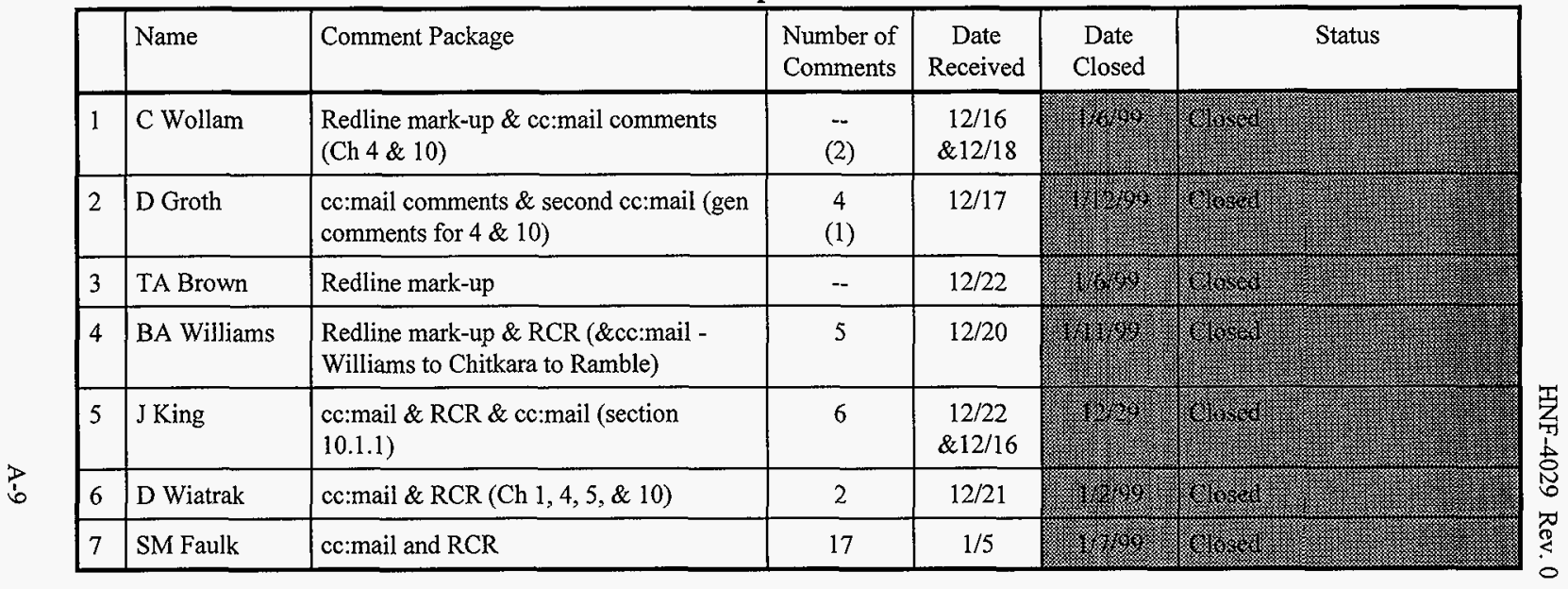

Chapter 12

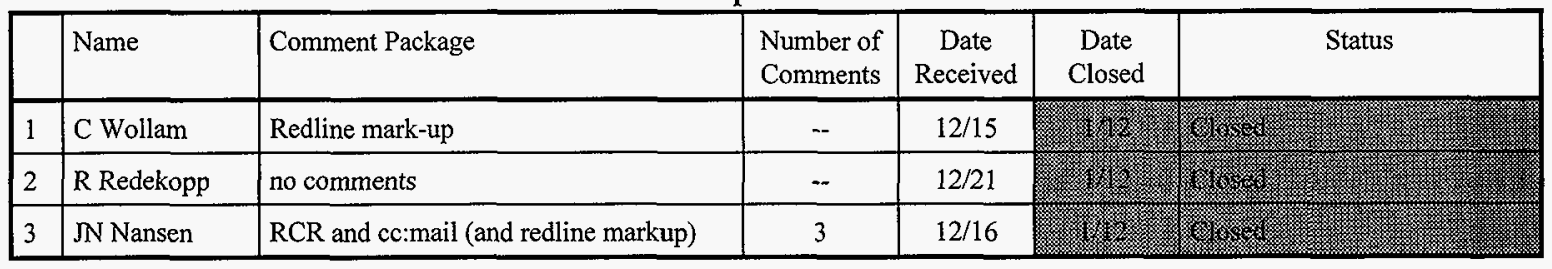

Note: Shaded boxes indicate that the comment package is closed out 
HNF-4029 Rev. 0

This page intentionally left blank. 
HNF-4029 Rev. 0

\section{Appendix B}

\section{Closed Review Comment Records}

B-1 
HNF-4029 Rev. 0

This page intentionally left blank. 


\begin{tabular}{|c|c|c|}
\hline & $\begin{array}{l}\text { 1. Date } \\
1 / 12 / 99 \\
\end{array}$ & $\begin{array}{c}\text { 2. Review No. } \\
1 \\
\end{array}$ \\
\hline REVIEW COMMENT RECORD (RCR) & $\begin{array}{l}\text { 3. Project No. } \\
\text { PFP FSAR }\end{array}$ & 4. Page 1 of 1 \\
\hline
\end{tabular}

\section{Document Number(s)/Title(s) \\ HNF-SD-CP-SAR-021, Revision 1, Chapters 1-10 and 12}

6. Program/Project/ Building Number PFP FSAR

\section{Reviewer \\ D. Busche, S. Nunn, \& D. Conners}

\begin{tabular}{l|l}
\hline 8. Organization/Group & 9. Location/Phone \\
& \\
PFP Safety & $234-5 Z$ \\
& $373-3337$ \\
\hline
\end{tabular}

10. Agreement with indicated comment disposition(s)

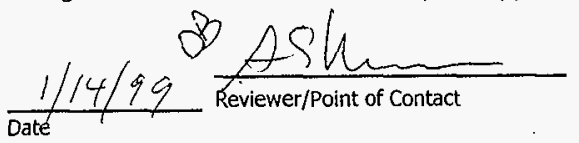

Author/Originator
11. CLOSED

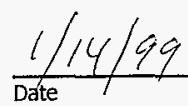

Reviewer/Point of Contact

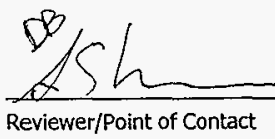

Author/Originator

Author/Originator

\begin{tabular}{|c|c|c|c|c|}
\hline $\begin{array}{l}12 . \\
\text { Ite } \\
\mathrm{m}\end{array}$ & $\begin{array}{l}\text { 13. Comment(s)/Discrepancy(s) (Provide technical justification for the } \\
\text { comment and detailed recommendation of the action required to } \\
\text { correct/ resolve the discrepancy/problem indicated.) }\end{array}$ & $\begin{array}{l}14 . \\
\text { Hold } \\
\text { Point }\end{array}$ & 15. Disposition (Provide justification if NOT accepted.) & $\begin{array}{l}16 . \\
\text { Status }\end{array}$ \\
\hline 1. & $\begin{array}{l}\text { Due to the expedited review on the FSAR update package, } \\
\text { PFP Safety did not formally document their comments on } \\
\text { this form. The document has been reviewed. PFP Safety } \\
\text { comments have been discussed, dispositioned, and } \\
\text { adequately resolved during several working sessions with } \\
\text { Chapter authors. }\end{array}$ & & No further action required. & \\
\hline 2. & & & & \\
\hline
\end{tabular}

A-6400-090.1 (03/92) WEF011 


\section{REVIEW COMMENT RECORD (RCR)}

\begin{tabular}{|c|c|}
\hline $\begin{array}{c}\text { 1. Date } \\
1 / 6 / 99\end{array}$ & 2. $\begin{array}{r}\text { Review No. } \\
\hline \begin{array}{c}\text { 3. Project No. } \\
\text { PFP FSAR }\end{array}\end{array}$ \\
\hline
\end{tabular}

5. Document Number(s)/Title(s)

HNF-SD-CP-SAR-021, Chapter 1
17. Comment Submittal Approval

Organization Manager (Optional)

to

\begin{tabular}{l|l}
\hline $\begin{array}{l}\text { 12. } \\
\text { Ite } \\
\text { m }\end{array}$ & $\begin{array}{l}\text { 13. Comment(s)/Discrepancy(s) (Provide technical justification } \\
\text { for the comment and detailed recommendation of the action required } \\
\text { to correct/ resolve the discrepancy/problem indicated.) }\end{array}$ \\
\hline & \\
\hline 1. & Comments received as redline markups on chapter 1. \\
\hline 2. & \\
\hline 3. & \\
\hline 4. & \\
\hline & \\
\hline
\end{tabular}

\begin{tabular}{|l|l|}
$\begin{array}{l}\text { 6. Program/Project/ } \\
\text { Building Number } \\
\text { PFP FSAR }\end{array}$ & 7. Reviewer \\
& CD Woll lam \\
\hline
\end{tabular}

10. Agreement with indicated comment

\begin{tabular}{l|l|}
\hline 8. Organization/Group & 9. Location/Phone \\
Technical & \\
Integration and SRB & \\
Chairman & \\
\hline
\end{tabular}

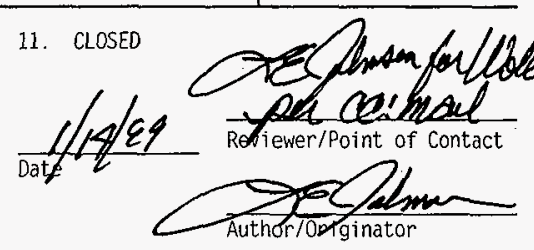

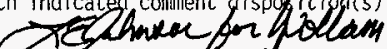
Les ceimail $\frac{1}{104} 4499$ Revewer/Point of Contact

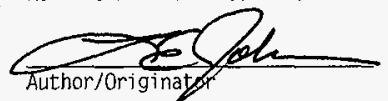

14. 15. Disposition (Provide justification if NOT 16. Hold accepted. ) $s$

\begin{tabular}{l}
\hline \\
\hline \\
\hline \\
\hline
\end{tabular}


HNF-4029 Rev. 0

\section{Johnson, L E (Safety Analysis)}

From:

Sent:

Wollam, C D (Chris)

To: Thursoay, January 14, 1999 1:15 PM

Subject: Johnson, L.E (Safety Analysis) RE: PFP FSAR RCR Closeout

Larry,

I have discussed these with the authors and consider my comments resolved.

CDW

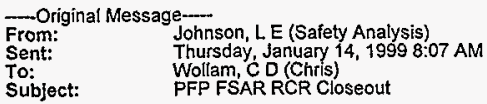

Chris,

I've attached files of the chapter 1, 3 and 7 RCRs. If acceptable, please respond back that you consider the RCRs closed. Thanks for your support and patience during this functional review.

Larry Johnson

« File: CDW1DISP.RCR $\gg<$ File: CDW3DISP.RCR $\gg><$ File: CDW7DISP.RCR $\gg$

Note - these are WP 6.1 files 


\section{REVIEW COMMENT RECORD (RCR)}

\begin{tabular}{|c|c|}
\hline $\begin{array}{l}\text { 1. Date } \\
1 / 6 / 99\end{array}$ & $\begin{array}{r}\text { 2. Review No. } \\
1 \\
\end{array}$ \\
\hline $\begin{array}{l}\text { 3. Project No. } \\
\text { PFP FSAR }\end{array}$ & 4. Page \\
\hline
\end{tabular}

5. Document Number(s)/Title(s)

HNF-SD-CP-SAR-021, Chapter 1

\begin{tabular}{l|l}
$\begin{array}{l}\text { 6. Program/Project/ } \\
\text { Building Number } \\
\text { PFP FSAR }\end{array}$ & R. Reviewer \\
& RO Redekopp
\end{tabular}

\begin{tabular}{l|l} 
8. Organization/Group & 9. Location/Phone \\
PFP Operations &
\end{tabular}

17. Comment Submittal Approval:

Organization Manager (Optional)

Ð

a 13 Comment(s)/Discrepancy(s) (Provide technical justification

Ite for the comment and detailed recommendation of the action required

$m$ to correct/ resolve the discrepancy/problem indicated.)

\section{Chapter 1}

1. Comments on Chapter 1 received as redline markups.

\section{punveleho}

Reviewer/Point of Contact

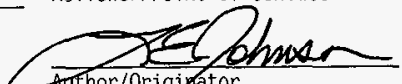

11. CLOSEO

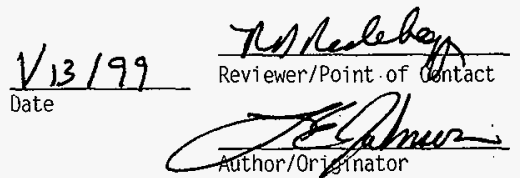

14.

Hold Point
15. Disposition (Provide justification if NOT accepted.)

2.

3.

4.

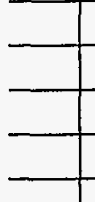

A-6400-090.1 (03/92) WEF011 


\begin{tabular}{|c|c|c|}
\hline DEUTCLI & $\begin{array}{l}\text { 1. Date } \\
\text { December 21, } 1998\end{array}$ & $\begin{array}{r}2 . \text { Review No. } \\
1 \\
\end{array}$ \\
\hline KEV & $\begin{array}{l}\text { 3. Project No. } \\
\text { N/A }\end{array}$ & $\begin{array}{l}\text { 4. Page } 1 \text { of } 3 \\
\end{array}$ \\
\hline
\end{tabular}

5. Document Number(s)/Title(s)

Final Safety Analysis Report (FSAR) HNF-SD-CP-SAR-021. Rev. I

17. Comment Submittal Approval:

Organization Manager (Optional)

$\varpi$

\begin{tabular}{l|l}
$\begin{array}{l}\text { 6. Program/Project/ } \\
\text { Building Number } \\
\text { Plutonium }\end{array}$ & 7. Reviewer \\
$\begin{array}{l}\text { Finishing Plant } \\
\text { (PFP) }\end{array}$ & DJ WIATRAK/FDH \\
\hline
\end{tabular}

10. Agreement with indicated comment-dispogition(s). $01 / 07 / 99$

$\overline{\text { Date }}$ Re/iewer/Point of Contact

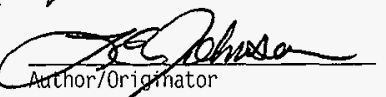

8. Organization/Group
OCCUPATIONAL SAFETY
\& HEALTH

9. Location/Phone

2355 Stevens Dr. 376-8805/3739027

\section{CLOSED $01 / 07 / 99$}

$\overline{\text { Date }}$

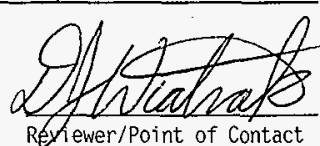

Rer ewer/Point of Contact

12. 13. Comment(s)/Discrepancy(s) (Provide techmical justification

Ite for the comment and detailed recommendation of the action required

$\mathrm{m}$ to correct/ resolve the discrepancy/problem indicated.)

\begin{tabular}{|l|l|l|l}
\hline 14. & 15.0 Disposition (Provide justification if MOT & 16
\end{tabular}

1. Chapter 4 - Section 4.4.8. Item 3, states that compressed gas system installations meet the requirements of WHC-CM-4-40 and WHC-CM-1-10. These two references are no longer applicable. A similar update is also needed in the References Section (Page R4-5).

2. Chapter 4 - The last sentence to Section 4.4.8, Item 10 , is missing an intended document reference.

3. Chapter 4 - Section 4.4.8 fails to acknowledge that requirements are in place for design, operation, and maintenance of overhead cranes and hoists.

It is a typo "tab" which left extra spaces.

Accept, added sentence to item \#12. 


\begin{tabular}{|l|l|l|l|}
\hline \multirow{2}{*}{ REVIEW COMMENT RECORD (RCR) } & $\begin{array}{l}\text { Date Review No. } \\
\text { December } 21,1998\end{array}$ \\
\cline { 2 - 3 } & $\begin{array}{r}3 . \text { Project No. } \\
\text { N/A }\end{array}$ & $\begin{array}{r}4 . \text { Page } \\
2 \text { of } 3\end{array}$ \\
\hline
\end{tabular}

\begin{tabular}{|c|c|c|c|c|}
\hline $\begin{array}{l}12 . \\
\text { Ite } \\
\text { m }\end{array}$ & $\begin{array}{l}\text { 13. Comment(s)/Discrepancy(s) (Provide technical justification } \\
\text { for the comment and detailed recommendation of the action required } \\
\text { to correct/ resolve the discrepancy/problem indicated.) }\end{array}$ & $\begin{array}{l}14 . \\
\text { Hoid } \\
\text { Point }\end{array}$ & $\begin{array}{l}\text { 15. Disposition (Provide justification if NOT } \\
\text { accepted.) }\end{array}$ & $\begin{array}{l}16 . \\
\text { Statu } \\
5 \\
\end{array}$ \\
\hline 4. & $\begin{array}{l}\text { Chapter } 4 \text { - Section } 4.4 .8 \text { (\#10), the reference of } \\
\text { "(29 CFR 1910.1200) imposed if carcinogenic } \\
\text { materials are used" should be changed to read " } \\
\text { imposed if hazardous chemicals are used". }\end{array}$ & & text revision made as recommended. & \\
\hline 5. & $\begin{array}{l}\text { Chapter } 1 \text { - In Section } 1.2 .2 .4 .3 \text {, the numerical } \\
\text { range given for procedures within the } \mathrm{FDH} / \mathrm{OSH} \\
\text { discipline is incorrect. }\end{array}$ & & $\begin{array}{l}\text { Deleted the reference to specific procedures } \\
\text { and referenced the Occupational Safety \& } \\
\text { Health topical series of procedures. }\end{array}$ & \\
\hline 6. & $\begin{array}{l}\text { Chapter } 1 \text { - In section } 1.2 .1 \text {, the description of the } \\
3000 \text { Areas needs to be updated. }\end{array}$ & & $\begin{array}{l}\text { Changed text to read "This area is not } \\
\text { generally used by the Hanford Site } \\
\text { Contractors." }\end{array}$ & \\
\hline $\begin{array}{l}12 . \\
\text { Ite } \\
\mathrm{m}\end{array}$ & $\begin{array}{l}\text { 13. Comment(s)/Discrepancy(s) (Provide technical justification } \\
\text { for the comment and detailed recommendation of the action required } \\
\text { to correct/ resolve the discrepancy/problem indicated.) }\end{array}$ & $\begin{array}{l}14 . \\
\text { Hoid } \\
\text { Point }\end{array}$ & $\begin{array}{l}\text { 15. Disposition (Provide justification if NOT } \\
\text { accepted.) }\end{array}$ & $\begin{array}{l}16 . \\
\text { Statu } \\
\mathrm{s} \\
\end{array}$ \\
\hline 7. & $\begin{array}{l}\text { Chapter } 5 \text { - Section } 5.4 .12 .2 \text { is a suggested location } \\
\text { for incorporation of some ISMS language, in view of } \\
\text { PFP's progress and future plans involving work } \\
\text { planning enhancements. }\end{array}$ & & $\begin{array}{l}\text { This item is not in the scope of the FSAR } \\
\text { revision at this time and is not appropriate } \\
\text { in the context of the section referenced. } \\
\text { ISMS is more appropriate in chapters } 1 \text { and } \\
10 \text {. }\end{array}$ & \\
\hline 8 & $\begin{array}{l}\text { Chapter } 5 \text { - Section } 5.4 .13 .5 \text { should state that } \\
\text { MSDS's are available through the RMIS system and } \\
\text { from WMH. There has been a transfer of work scope } \\
\text { from HEHF to WMH for this service. }\end{array}$ & & Accept, text revised as requested. & \\
\hline
\end{tabular}




\begin{tabular}{|c|c|c|}
\hline & $\begin{array}{l}\text { 1. Date } \\
\text { December } 21,1998\end{array}$ & $\begin{array}{r}\text { 2. Review No. } \\
1 \\
\end{array}$ \\
\hline$W$ & $\begin{array}{r}\text { 3. Project No. } \\
\text { N/A }\end{array}$ & $\begin{array}{l}\text { 4. Page } 3 \text { of } 3\end{array}$ \\
\hline
\end{tabular}

\begin{tabular}{|c|c|c|c|c|}
\hline $\begin{array}{l}12 . \\
\text { Ite } \\
\text { m }\end{array}$ & $\begin{array}{l}\text { 13. Comment(s)/Discrepancy(s) (Provide technical justification } \\
\text { for the comment and detailed recomnendation of the action required } \\
\text { to correct/ resolve the discrepancy/problem indicated.) }\end{array}$ & $\begin{array}{l}14 . \\
\text { Hoid } \\
\text { Point }\end{array}$ & $\begin{array}{l}\text { 15. Disposition (Provide justification if NOT } \\
\text { accepted.) }\end{array}$ & $\begin{array}{l}16 . \\
\text { Statu } \\
\mathrm{s}\end{array}$ \\
\hline 9. & $\begin{array}{l}\text { Chapter } 5 \text { - Section } 5.4 .14 \text { (or within the discussion } \\
\text { of PFP Laboratories) should refer to your facility- } \\
\text { specific Chemical Hygiene Plan. It should also be } \\
\text { included in the reference section for this chapter. }\end{array}$ & & $\begin{array}{l}\text { A sentence has been added referencing the } \\
\text { Chemical Hygiene Plan as governing chemical } \\
\text { safety in the labs. }\end{array}$ & \\
\hline 10. & $\begin{array}{l}\text { Chapter } 10 \text { - Section } 10.1 .1 .7 \text { infers that the } \\
\text { primary BWHC interface is with DOE-RL. This is in } \\
\text { conflict with the contractural role of FDH as the } \\
\text { Site Integrator. }\end{array}$ & & & \\
\hline 11. & $\begin{array}{l}\text { Chapter } 10 \text { - Section } 10.3 \text { fails to define the role } \\
\text { of Project Hanford Management Procedures (HNF-PRO's) } \\
\text { in the requirements management system. }\end{array}$ & & & \\
\hline
\end{tabular}




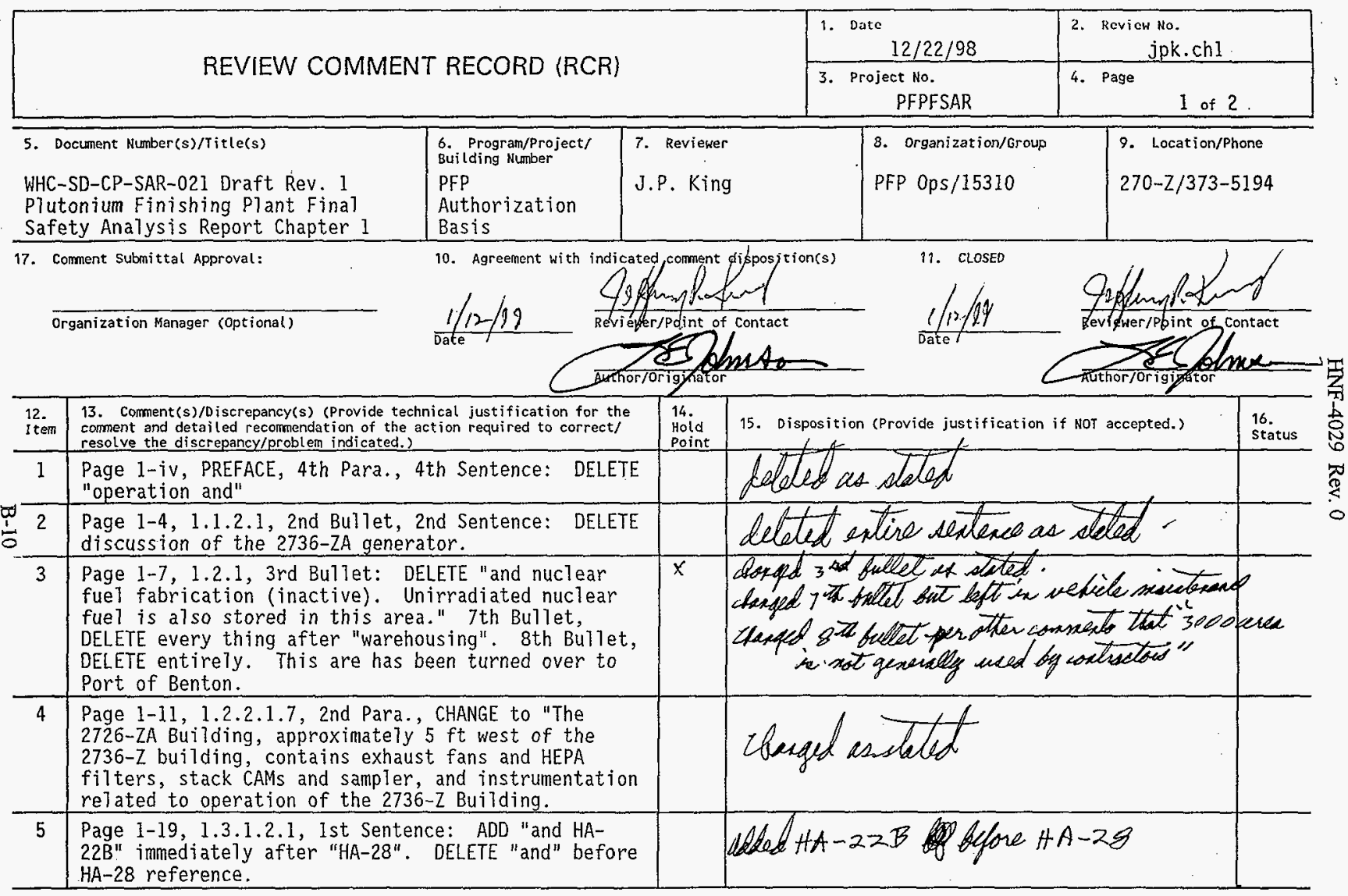




\begin{tabular}{|c|c|c|}
\hline & $\begin{array}{l}\text { 1. Date } \\
12 / 22 / 98 \\
\end{array}$ & $\begin{array}{l}\text { 2. Review No. } \\
\text { jpk.ch1 }\end{array}$ \\
\hline REVIEW COMMENT RECORD (RCR) & $\begin{array}{l}\text { 3. Project No. } \\
\text { PFPFSAR }\end{array}$ & 4. Page \\
\hline
\end{tabular}

\begin{tabular}{|c|c|c|c|c|}
\hline $\begin{array}{l}12 . \\
\text { Item }\end{array}$ & $\begin{array}{l}\text { 13. Comment(s)/Discrepancy(s) (Provide technical justification for the } \\
\text { comment and detailed recomendation of the action required to correct/ } \\
\text { resolve the discrepancy/problem indicated.) }\end{array}$ & $\begin{array}{l}14 . \\
\text { Hoid } \\
\text { Point }\end{array}$ & 15. Disposition (Provide justification if NOT accepted.) & $\begin{array}{l}\text { 16. } \\
\text { status }\end{array}$ \\
\hline 6 & $\begin{array}{l}\text { Page 1-20, 1.3.1.5, lst Sentence: INSERT } \\
\text { "dispersible" between "as" and "radioactive". 4th } \\
\text { Sentence, CHANGE "because" to "once". }\end{array}$ & & charget as. & \\
\hline
\end{tabular}




\begin{tabular}{|c|l|l|}
\hline \multirow{2}{*}{ REVIEW COMMENT RECORD (RCR) } & $\begin{array}{l}\text { 1. Date } \\
1 / 6 / 99\end{array}$ & $\begin{array}{c}2 . \text { Review No. } \\
1\end{array}$ \\
\cline { 2 - 4 } & $\begin{array}{c}\text { 3. Project No. } \\
\text { PFP FSAR }\end{array}$ & $\begin{array}{l}4 . \\
\text { Page } \\
1\end{array}$ \\
\hline
\end{tabular}

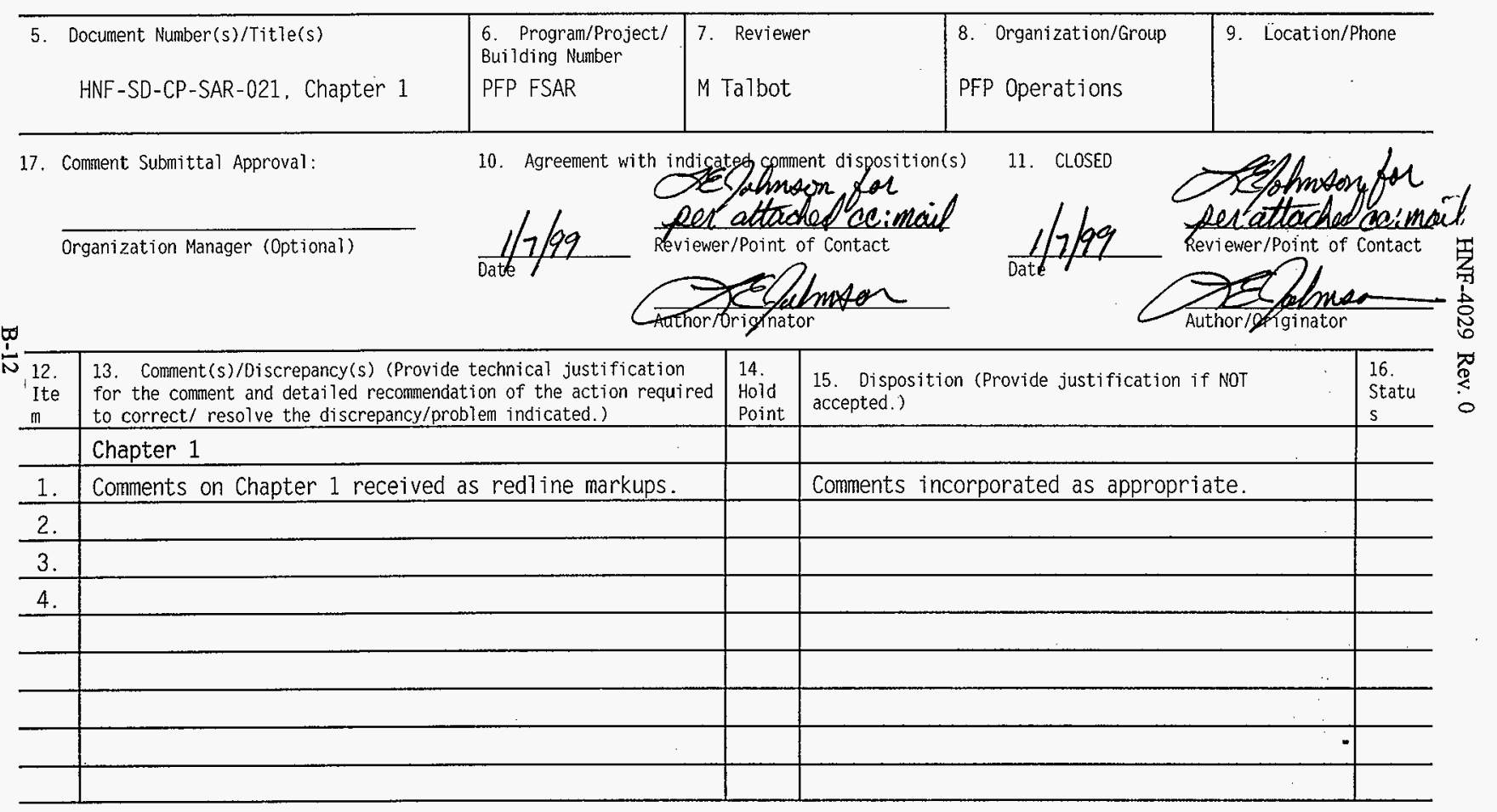


Johnson, LE (Safety Analysis)

From:

Sent:

To:

Subject:
Talbot, Michael D (Mick)

Thursday, January 07, 1999 5:13 PM

Johnson, LE (Safety Analysis)

RE: PFP FSAR Chapter 5 Comments

Larry,

I concur for both chapters.

Mick

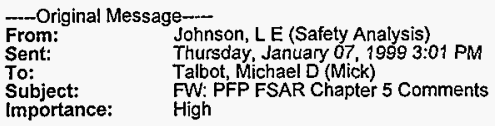

Mick,

Ditto for the Chapter 1 RCR.

Larry Johnson

«File: MDT1DISP.RCR 》

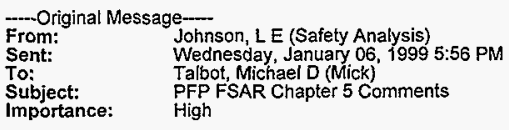

Mick,

You submitted redline comments on Chapter 5 . Jim Shapley has incorporated them as appropriate. I've filled out a RCR form indicating this, please see attached. If this is acceptable, please respond by cc;mail that you accept the disposition and consider the RCR closed.

Thanks,

Larry Johnson

$376-8807$

«File: MDT5DISP.RCR $\gg$ 


\begin{tabular}{|c|c|c|}
\hline & \begin{tabular}{|r|} 
1. Date \\
\\
$1 / 6 / 99$ \\
\end{tabular} & $\begin{array}{r}\text { 2. Review No. } \\
1 \\
\end{array}$ \\
\hline REVIEW CUMVIENI RECURD (RCR) & $\begin{array}{r}\text { 3. Project No. } \\
\text { PFP FSAR }\end{array}$ & \begin{tabular}{|l|l|} 
4. Page & 1 of 1 \\
\end{tabular} \\
\hline
\end{tabular}

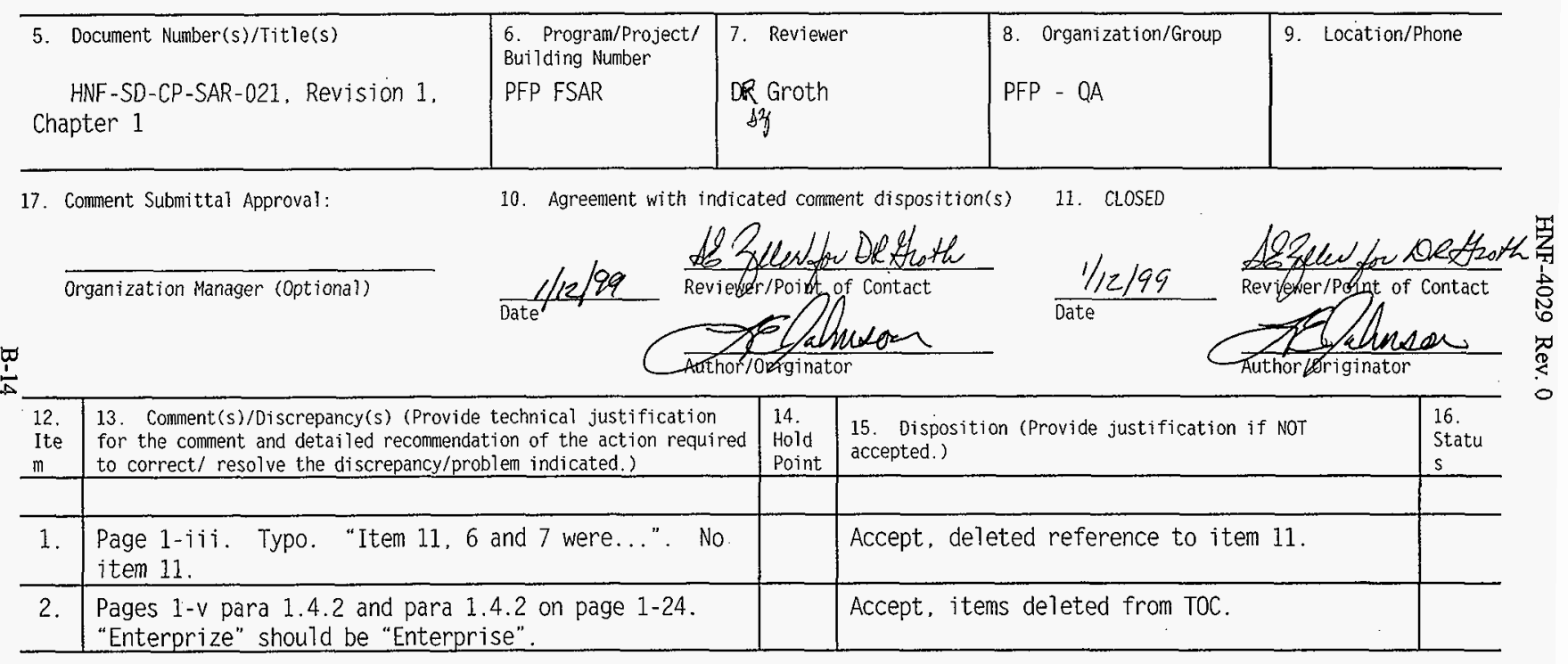




\begin{tabular}{|c|c|c|}
\hline & $\begin{array}{l}\text { 1. Date } \\
1 / 6 / 99\end{array}$ & $\begin{array}{r}\text { 2. Review No. } \\
1 \\
\end{array}$ \\
\hline$=W C$ & $\begin{array}{l}\text { 3. Project No. } \\
\text { PFP FSAR }\end{array}$ & $\begin{array}{l}\text { 4. Page } \\
2 \text { of } 1\end{array}$ \\
\hline
\end{tabular}

\begin{tabular}{|c|c|c|c|c|}
\hline $\begin{array}{l}12 . \\
\text { Ite } \\
\mathrm{m}\end{array}$ & $\begin{array}{l}\text { 13. Comment(s)/Discrepancy(s) (Provide technical justification } \\
\text { for the comment and detailed recommendation of the action required } \\
\text { to correct/ resolve the discrepancy/problem indicated.) }\end{array}$ & $\begin{array}{l}14 . \\
\text { Hold } \\
\text { Point }\end{array}$ & $\begin{array}{l}\text { 15. Disposition (Provide justification if NOT } \\
\text { accepted.) }\end{array}$ & $\begin{array}{l}16 . \\
\text { Statu } \\
\text { s }\end{array}$ \\
\hline 3 & $\begin{array}{l}\text { Para 1.3.1.2.1 and 1.3.1.2A. Just an observation... } \\
\text { here, HA21I nad the VDC are discussed as if } \\
\text { authorized for use. There is mention elsewhere that } \\
\text { they are not. so it seems odd to have them discussed } \\
\text { in that fashion. }\end{array}$ & & $\begin{array}{l}\text { No change made. The preface explains that } \\
\text { they are not authorized and section 1.1.1.1 } \\
\text { and } 1.1 .1 .2 \text { define active and inactive } \\
\text { processes. Solution stabilization (VDC) and } \\
\text { HC21I are listed as inactive. Note - this } \\
\text { is how Mr Ramble wants this handled in the } \\
\text { FSAR. }\end{array}$ & \\
\hline 4. & $\begin{array}{l}\text { Page R1-1. } \\
\text {-- "Babcock \& Wi 1cox Hanford Company" should be "B\&W } \\
\text { Hanford Company". } \\
\text {--IP-0821 may have a HNF prefix by no. }\end{array}$ & & $\begin{array}{l}\text { Accept, change as stated. } \\
\text { Accept, changed to current reference. }\end{array}$ & \\
\hline & & & & \\
\hline & & & & \\
\hline & & & & \\
\hline & & & & \\
\hline & & & & \\
\hline & & & & \\
\hline & & & & \\
\hline & & & & \\
\hline
\end{tabular}




\begin{tabular}{|l|l|l|}
\hline \multirow{2}{*}{ REVIEW COMMENT RECORD (RCR) } & $\begin{array}{l}\text { 1. Date } \\
1 / 6 / 99\end{array}$ & $\begin{array}{c}\text { Review No. } \\
1\end{array}$ \\
\cline { 2 - 4 } & $\begin{array}{c}\text { 3. Project No. } \\
\text { PFP FSAR }\end{array}$ & $\begin{array}{l}4 . \text { Page } \\
1 \text { of } 2\end{array}$ \\
\hline
\end{tabular}

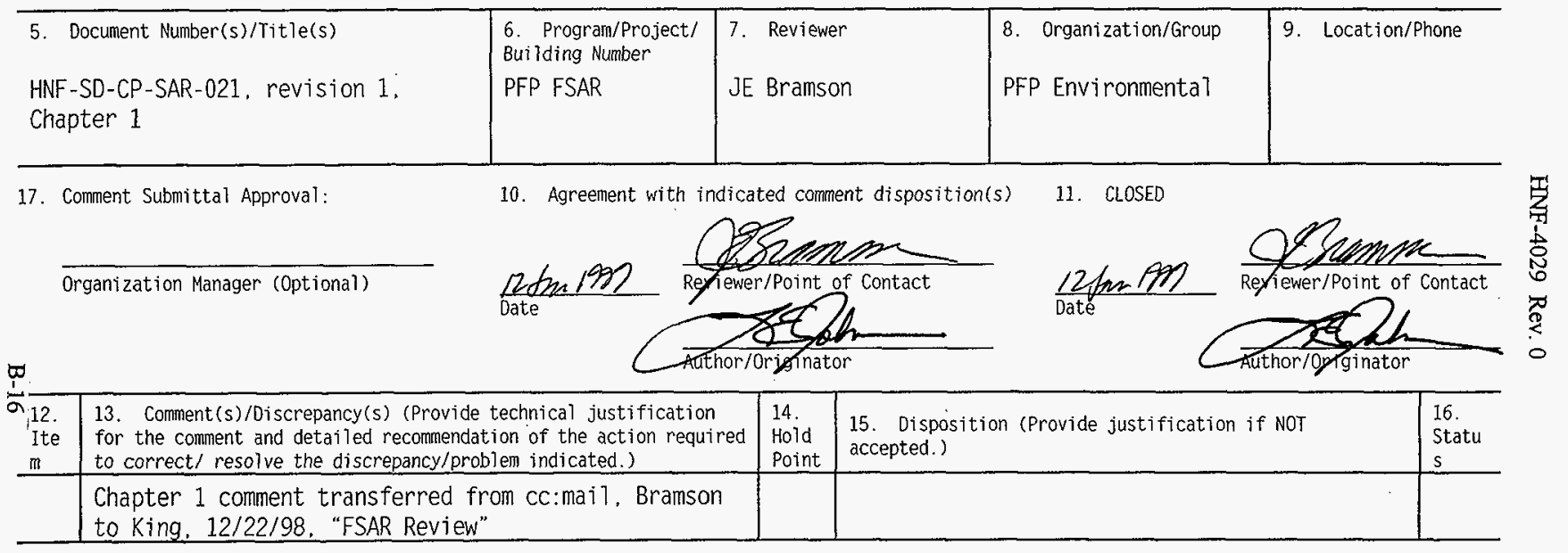


HNF-4029 Rev. 0

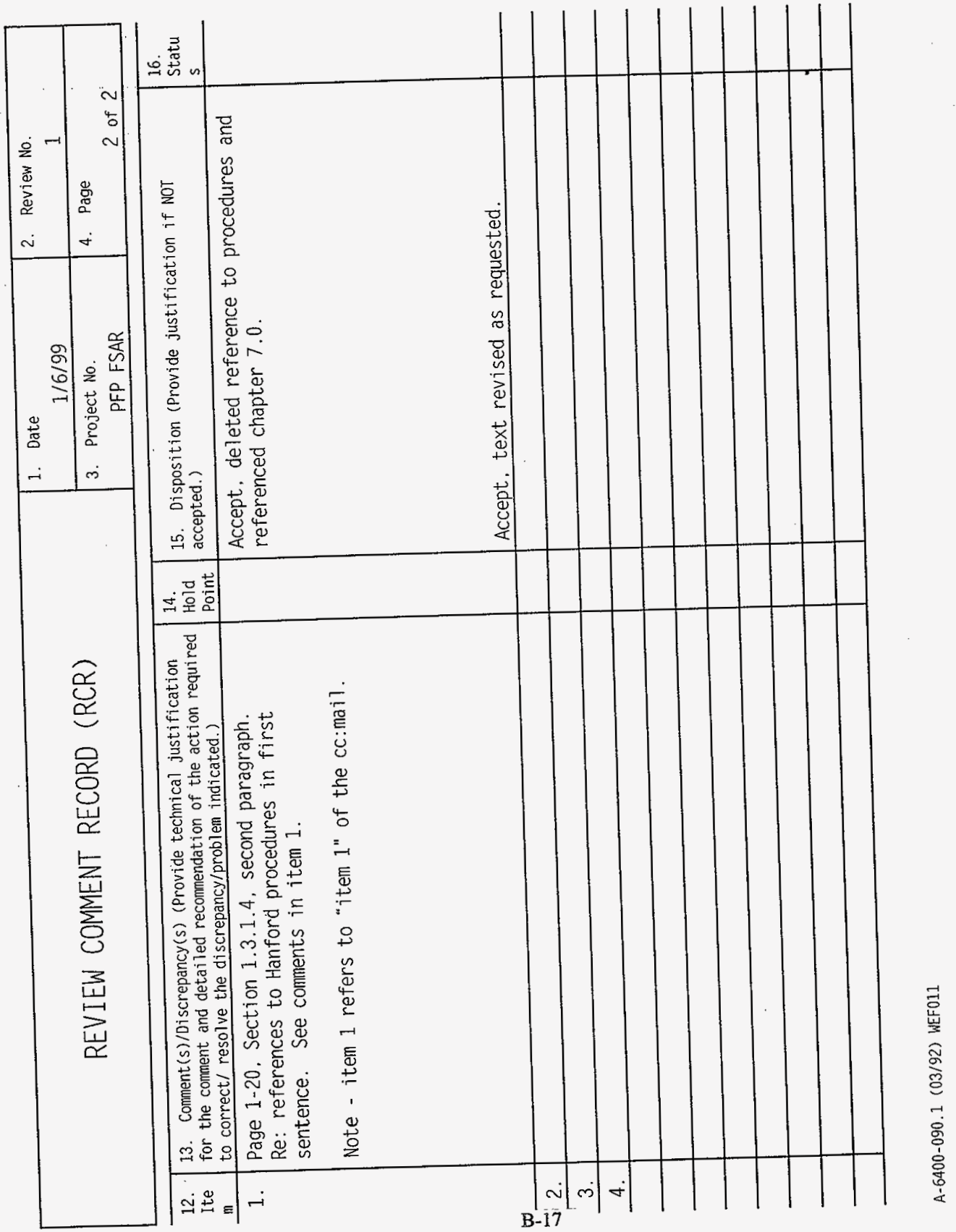




\section{REVIEW COMMENT RECORD (RCR)}

\begin{tabular}{|c|c|}
\hline $\begin{array}{l}\text { 1. Date } \\
1 / 13 / 99\end{array}$ & 2. Review No. \\
\hline $\begin{array}{c}\text { 3. Project No. } \\
\text { PFP FSAR }\end{array}$ & 4. Page \\
\hline
\end{tabular}

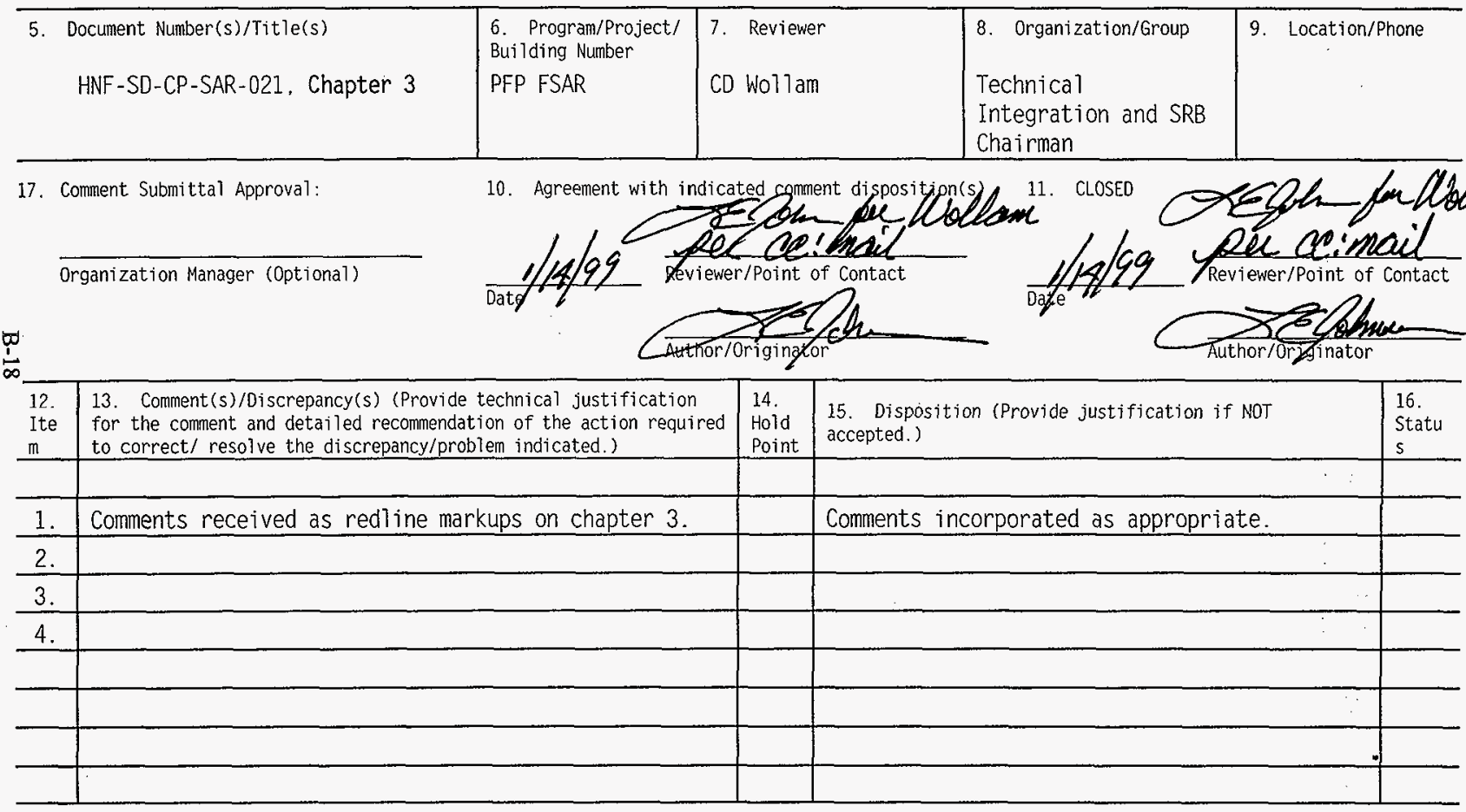


HNF-4029 Rev. 0

Johnson, LE (Safety Analysis)

From:

Sent:

Wollam, C D (Chris)

Thursday, January 14, 1999 1:15 PM

To:

Subject:

Johnson, LE (Safety Analysis)

RE: PFP'FSAR RCR Closeout

Larry,

I have discussed these with the authors and consider my comments resolved.

CDW

From:

Sent: $\quad$ Thursday, January 14, 1999 8:07 AM

To: Wollam, C D (Chris)

Subject: $\quad$ PFP FSAR RCR Closeout

Chris,

I've attached files of the chapter 1, 3 and 7 RCRs. If acceptable, please respond back that you consider the RCRs closed. Thanks for your support and patience during this functional review.

Larry Johnson

« File: CDW1DISP.RCR $\gg<<$ File: CDW3DISP.RCR $\gg<<$ File: CDW7DISP.RCR $\gg$

Note - these are WP 6.1 files 


\section{REVIEW COMMENT RECORD (RCR)}

\begin{tabular}{|c|c|}
\hline $\begin{array}{c}\text { 1. Date } \\
12 / 10 / 98\end{array}$ & $\begin{array}{l}\text { 2. Review No. } \\
\text { jpk.ch3 }\end{array}$ \\
\hline $\begin{array}{c}\text { 3. Project No. } \\
\text { PFPFSAR }\end{array}$ & 4. Page 1 of 2 \\
\hline
\end{tabular}

5. Document Number(s)/Title(s)

WHC-SD-CP-SAR-021 Draft Rev. I Plutonium Finishing Plant Final Safety Analysis Report Chapter 3

17. Comment Subrittal Approval:

\begin{tabular}{l|l}
$\begin{array}{l}\text { 6. Program/Project/ } \\
\text { Building Number }\end{array}$ & 7. Reviewer \\
PFP & J.P. King \\
Authorization & \\
Basis &
\end{tabular}

10. Agreement with indicated/comment disposition(s)

10. Agreement with indicated/coment dispositiongs

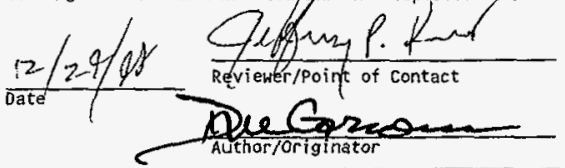

8. Organi zation/Group

PFP Ops $/ 15310$
9. Location/Phone

$270-2 / 373-5194$
11. CLOSED

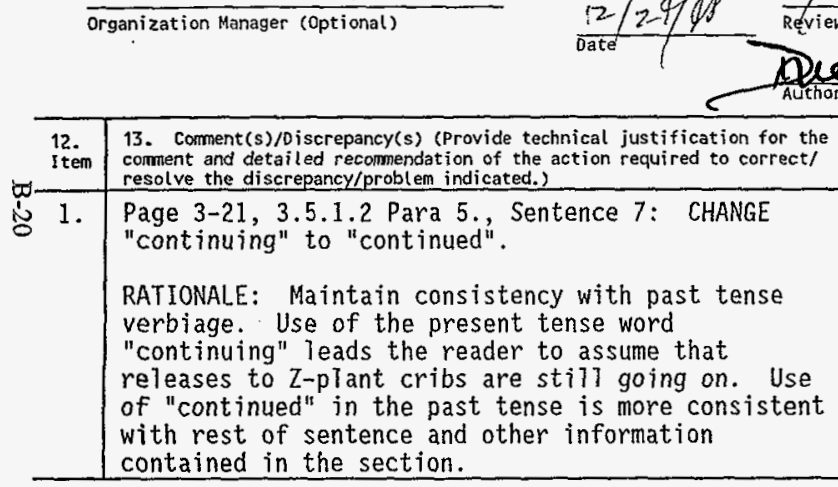

Organization Manager (Optional) Item comment and detailed recommendation of the action required to correct/ resolve the discrepancy/problem indicated.)
"continuing" to "continued".
RATIONALE: Maintain consistency with past tense verbiage. Use of the present tense word
"continuing" leads the reader to assume that releases to Z-plant cribs are still going on. Use of "continued" in the past tense is more consistent with rest of sentence and other information contained in the section.

12. 13. Comment(s)/Discrepancy(s) (Provide technical justification for the

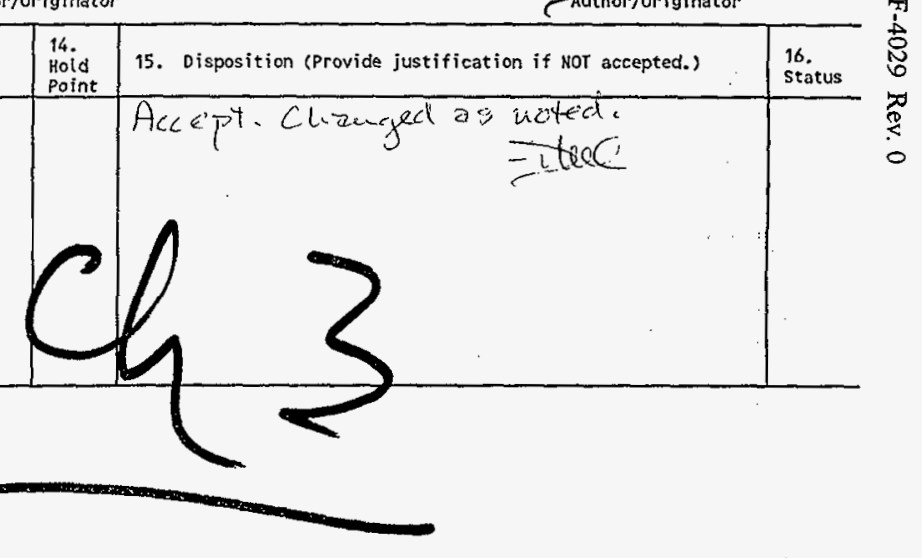




\begin{tabular}{|l|l|l|l|}
\hline \multirow{2}{*}{ REVIEW COMMENT RECORD (RCR) } & $\begin{array}{l}\text { i. Date Review No. } \\
\text { jpk. ch3 }\end{array}$ & \begin{tabular}{l}
$12 / 10 / 98$ \\
\cline { 2 - 3 }
\end{tabular} & $\begin{array}{c}\text { 3. Project No. Page } \\
\text { PFPFSAR }\end{array}$ \\
\hline
\end{tabular}

\begin{tabular}{|c|c|c|c|c|}
\hline $\begin{array}{l}12 . \\
\text { item }\end{array}$ & $\begin{array}{l}\text { 13. Comment }(s) / 0 \text { iscrepancy(s) (Provide technical justification for the } \\
\text { comment and detailed recommendation of the action required to correct/ } \\
\text { resolve the discrepancy/problem indicated.) }\end{array}$ & $\begin{array}{l}14 . \text { iq } \\
\text { Hoid } \\
\text { Point }\end{array}$ & 15. Disposition (Provide justification if NOT accepted.) & $\begin{array}{l}16 . \\
\text { Status }\end{array}$ \\
\hline 2. & $\begin{array}{l}\text { Page 3 23, 3.5.2, Para 6., lst sentence: CHANGE to } \\
\text { "Wells are currently sampled in the vicinity of PFP } \\
\text { according to the Environmental Monitoring Plan } \\
\text { United States Department of Energy Richland } \\
\text { Operations Office, DOE/RL-91-50." } \\
\text { RATIONALE: I called Bruce Williams of PNNL to } \\
\text { identify where the WHC groundwatering monitoring } \\
\text { plan had been dispositioned to. He related it had } \\
\text { been broken up into pieces between Bechtel and PNNL } \\
\text { and recommended referencing the DOE/RL-9l-50 } \\
\text { document, which points to groundwater programs } \\
\text { applicable to PFP. }\end{array}$ & & $\begin{array}{r}\text { Accept. Changed as uarted, } \\
\text { - Dtest }\end{array}$ & \\
\hline
\end{tabular}

四 


\section{REVIEW COMMENT RECORD (RCR)}

\begin{tabular}{|c|l|}
\hline $\begin{array}{l}\text { 1. Date } \\
1 / 8 / 99\end{array}$ & 2. Review No. \\
\hline $\begin{array}{c}\text { 3. Project No. } \\
\text { PFP FSAR }\end{array}$ & 4. Page 1 of 1 \\
\hline
\end{tabular}

5. Document Number(s)/Title(s)

HNF-SD-CP-SAR-021, Chapter 3

17. Comment Submittal Approval:

Organization Manager (Optional)

\begin{tabular}{l|l}
$\begin{array}{l}\text { 6. Program/Project/ } \\
\text { Building Number } \\
\text { PFP FSAR }\end{array}$ & 7. Reviewer \\
& RD Redekopp
\end{tabular}

10. Agreement with indicated comment disposition(s)

8. Organization/Group
PFP Operations.

9. Location/Phone

11. CLOSED

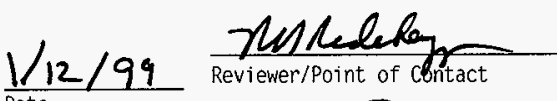

Date

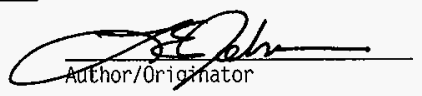

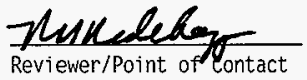

Date

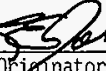

Author/orjginator
12. 13. Comment(s)/Discrepancy(s) (Provide technical justification

N. Ite for the comment and detailed recommendation of the action required

$\mathrm{m}$ to correct/ resolve the discrepancy/problem indicated.)

Chapter 3

1. Chapter 3 received as a redi ine markup.

\begin{tabular}{l|l}
\hline 2. & \\
\hline 3. & \\
\hline 4. & \\
\hline & \\
\hline & \\
\hline & \\
\hline &
\end{tabular}

15. Disposition (Provide justification if NOT Hold accepted.)

No comments identified in chapter markup.

\begin{tabular}{|l|l|l}
\hline $\begin{array}{l}14 . \\
\text { Hold } \\
\text { Point }\end{array}$ & $\begin{array}{l}\text { 15. Disposition (Provide justification if Nor } \\
\text { accepted.) }\end{array}$ & $\begin{array}{l}\text { Statu } \\
\text { sta }\end{array}$ \\
\hline & & \\
\hline & No comments identified in chapter markup. & \\
\hline & & \\
\hline & & \\
\hline & & \\
\hline & & \\
\hline & & \\
\hline
\end{tabular}




\begin{tabular}{|l|l|}
\hline $\begin{array}{c}\text { 1. } \\
\text { Date } \\
1 / 6 / 99\end{array}$ & $\begin{array}{c}\text { 2. Review No. } \\
4-2\end{array}$ \\
\hline \begin{tabular}{c} 
3. $\begin{array}{c}\text { Project No. } \\
\text { PFP FSAR }\end{array}$ \\
\hline
\end{tabular} & 4. Page 1 of 2 \\
\hline
\end{tabular}

\begin{tabular}{c|l|l|l|l|}
\hline 5. Document Number(s)/Title(s) & $\begin{array}{l}6 . \\
\text { Program/Project/ } \\
\text { Building Number } \\
\text { PFP FSAR }\end{array}$ & $\begin{array}{l}\text { 7. Reviewer } \\
\text { RDF Keck }\end{array}$ & $\begin{array}{l}8 . \\
\text { Organization/Group } \\
\text { PFP Facility Systems } \\
\text { Engineering }\end{array}$ & $\begin{array}{l}9 . \\
\text { Location/Phone }\end{array}$ \\
\hline
\end{tabular}

17. Comment Submittal Approval:

$\underset{⿱ 亠 乂}{\omega}$

Organization Manager (Optional)
10. Agreement with indicated comment disposition(s)

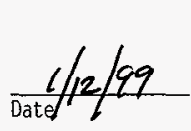

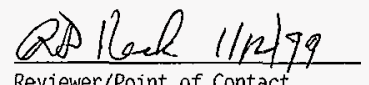

Reviewer/Point of Contact

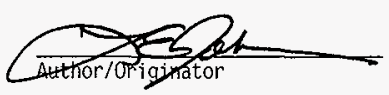

11. CLOSED

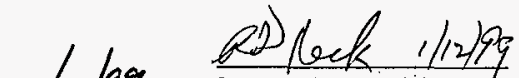
Reviewer/Point of Contact
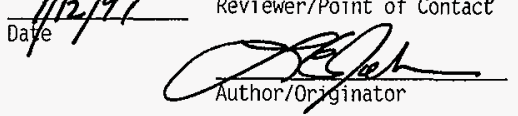

\begin{tabular}{l|l|l|l|l}
\hline 12 & $\begin{array}{l}\text { 13. Comment(s)/Discrepancy(s) (Provide technical } \\
\text { justification for the comment and detailed } \\
\text { It } \\
\text { ecommendation of the action required to correct/ } \\
\text { resolve the discrepancy/problem indicated.) }\end{array}$ & $\begin{array}{l}14 . \\
\text { Hold } \\
\text { Poin } \\
\mathrm{t}\end{array}$ & $\begin{array}{l}\text { 15. Disposition (Provide justification if } \\
\text { NOT accepted.) }\end{array}$ & $\begin{array}{l}\text { 16. } \\
\text { Statu } \\
\mathrm{s}\end{array}$ \\
\hline & & & & Will check and revise text as appropriate. \\
\hline 1. & $\begin{array}{l}\text { FSAR comments relative to backup ventilation for } \\
234-52 \\
\text { The backup ventilation will operate differentiy when }\end{array}$ & & -
\end{tabular}




\begin{tabular}{|c|c|c|}
\hline & $\begin{array}{l}\text { 1. Date } \\
1 / 6 / 99 \\
\end{array}$ & $\begin{array}{r}\text { 2. Review No. } \\
4-2\end{array}$ \\
\hline REVIEW COMMENT RECORD (RCR) & $\begin{array}{r}\text { 3. Project No. } \\
\text { PFP FSAR }\end{array}$ & $\begin{array}{l}\text { 4. Page } \\
2 \text { of } 2\end{array}$ \\
\hline
\end{tabular}

\begin{tabular}{|c|c|c|c|c|}
\hline $\begin{array}{l}12 \\
\text { It } \\
\text { em }\end{array}$ & $\begin{array}{l}\text { 13. Comment(s)/Discrepancy(s) (Provide technical } \\
\text { justification for the comment and detailed } \\
\text { recommendation of the action required to correct/ } \\
\text { resolve the discrepancy/problem indicated.) }\end{array}$ & $\begin{array}{l}14 . \\
\text { Hoid } \\
\text { Poin } \\
\mathrm{t}\end{array}$ & $\begin{array}{l}\text { 15. Disposition (Provide justification if } \\
\text { NOT accepted.) }\end{array}$ & $\begin{array}{l}16 . \\
\text { Statu } \\
s\end{array}$ \\
\hline & $\begin{array}{l}\text { using electrically powered fans instead of steam } \\
\text { turbines. } \\
\text { With steam turbines, the backup ventilation fans do } \\
\text { not start until the exhaust plenum pressure rises } \\
\text { above }-3.5 \text { " wg or on the loss of instrument air. } \\
\text { Then both steam driven fans start. } \\
\text { With electric fans for backup, one of the fans will } \\
\text { be run continuously under all ventilation and power } \\
\text { conditions. If a failure in the operating backup } \\
\text { fan is detected, the alternate backup fan will be } \\
\text { started. } \\
\text { The following pages in the draft FSAR need to be } \\
\text { changed to reflect this difference: } \\
4-i i i \\
4-15 \\
7-i i j \\
8-i i i \\
8-19 \\
8-26\end{array}$ & & & \\
\hline
\end{tabular}




\begin{tabular}{|c|c|}
\hline $\begin{array}{l}\text { 1. Date } \\
1 / 6 / 99 \\
\end{array}$ & $\begin{array}{c}\text { 2. Review No. } \\
4-2 \\
\end{array}$ \\
\hline $\begin{array}{r}\text { 3. Project No. } \\
\text { PFP FSAR }\end{array}$ & $\begin{array}{l}\text { 4. Page } \\
3 \text { of } 2\end{array}$ \\
\hline
\end{tabular}

\begin{tabular}{|c|c|c|c|c|}
\hline $\begin{array}{l}12 \\
\text { It } \\
\text { em }\end{array}$ & $\begin{array}{l}\text { 13. Comment(s)/Discrepancy(s) (Provide technical } \\
\text { justification for the comment and detailed } \\
\text { recommendation of the action required to correct/ } \\
\text { resolve the discrepancy/problem indicated.) }\end{array}$ & $\begin{array}{l}14 \\
\text { Hoid } \\
\text { Poin } \\
t\end{array}$ & $\begin{array}{l}\text { 15. Disposition (Provide justification if } \\
\text { NOT accepted.) }\end{array}$ & $\begin{array}{l}16 . \\
\text { Statu } \\
s\end{array}$ \\
\hline & $8-28$ & & & \\
\hline 2. & $\begin{array}{l}\text { Chapter } 4 \text {, page T4-10 item } 3 \text { - this should be the } \\
\text { public address system not the PAX system }\end{array}$ & & $\begin{array}{l}\text { Wil1 revise as appropriate. Changed to } \\
\text { "Pub7ic Address function of the PAX system" }\end{array}$ & \\
\hline & $\begin{array}{l}\text { Page T4-11 item } 10 \text { - the functional requirement for } \\
\text { the backup power system should include providing } \\
\text { backup power to the public address system. }\end{array}$ & & Will add. & \\
\hline \multicolumn{5}{|l|}{3.} \\
\hline \multicolumn{5}{|l|}{4.} \\
\hline & & & & \\
\hline & & & & \\
\hline & & & & \\
\hline & & & & \\
\hline & & & & \\
\hline & & & & \\
\hline & & & & \\
\hline
\end{tabular}




\section{REVIEW COMMENT RECORD (RCR)}

\begin{tabular}{|c|l|l|}
\hline $\begin{array}{c}\text { 1. } \text { Date } \\
1 / 13 / 99\end{array}$ & 2. Review No. \\
\hline \begin{tabular}{c} 
3. $\begin{array}{c}\text { Project No. } \\
\text { PFP FSAR }\end{array}$ \\
\hline
\end{tabular} & 4. Page \\
\end{tabular}

5. Document Number(s)/Title(s)

HNF-SD-CP-SAR-021, Chapter 4
6. Program/Project/ Building Number

PFP FSAR

7. Reviewer
DR Groth

10. Agreement with indicated comment disposition(s)

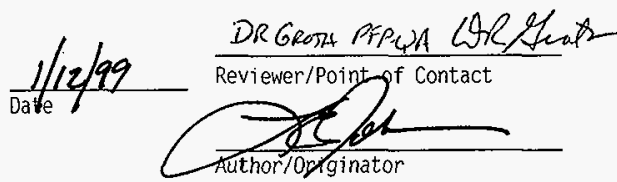

8. Organization/Group
PFP - QA

9. Location/Phone

17. Comment Submittal Approval:

Organization Manager (Optional)
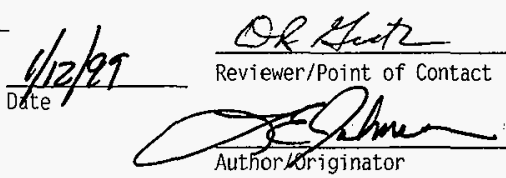

Author Wriginator

\begin{tabular}{|c|c|c|c|c|}
\hline $\begin{array}{l}\text { Ñ: } \\
\text { Ite } \\
\text { m }\end{array}$ & $\begin{array}{l}\text { 13. Comment(s)/Discrepancy(s) (Provide technical justification } \\
\text { for the comment and detailed recommendation of the action required } \\
\text { to correct/ resolve the discrepancy/problem indicated.) }\end{array}$ & $\begin{array}{l}14 . \\
\text { Hold } \\
\text { Point }\end{array}$ & $\begin{array}{l}\text { 15. Disposition (Provide justification if NOT } \\
\text { accepted.) }\end{array}$ & $\begin{array}{l}16 . \\
\text { Statu } \\
\mathrm{s}\end{array}$ \\
\hline & $\begin{array}{l}\text { Comment taken from cc:mai1, D Groth to Ramble and } \\
\text { Johnson, General Comment, 12/21/98. }\end{array}$ & & & \\
\hline 1. & $\begin{array}{l}\text { The Temperature for processing oxide, and performing } \\
\text { the LOI, has been changed from } 950 \text { to } 1000^{\circ} \mathrm{C} \text {. I } \\
\text { believe that I have seen the number } 950^{\circ} \mathrm{C} \text { in some } \\
\text { part of the text I have reviewed, but cannot now } \\
\text { find it. Suggest that a word search for " } 950^{\text {" be }} \\
\text { made in chapters } 4 \text { and } 10 \text {. }\end{array}$ & & $\begin{array}{l}\text { Accept. Al1 references to } 950 \text { have been } \\
\text { changed to } 1000^{\circ} \mathrm{C} \text { for the processing of } \\
\text { oxide. }\end{array}$ & \\
\hline \multicolumn{5}{|l|}{2.} \\
\hline 3. & & & & \\
\hline 4. & L & & & \\
\hline & & & & \\
\hline
\end{tabular}

A-6400-090.1 (03/92) WEF011 
Johnson, LE (Safety Analysis)

$\begin{array}{ll}\text { From: } & \text { Groth, Donald R (Don) } \\ \text { Sent: } & \text { Monday, December 21, 1998 11:42 AM } \\ \text { To: } & \text { Ramble, Alan L; Johnson, L E (Safety Analysis) } \\ \text { Cc: } & \text { Groth, Donald R (Don) } \\ \text { Subject: } & \text { General Comment }\end{array}$

Al, Larry: The temperature for processing Oxide, and performing the LOI, has been changed from 950 to $1000^{\circ} \mathrm{C}$. I believe that I have seen the number $950^{\circ} \mathrm{C}$ in some part of the text I have reviewed, but cannot now find it. Suggest that a word search for "950" be made in chapters 4 and 10 .

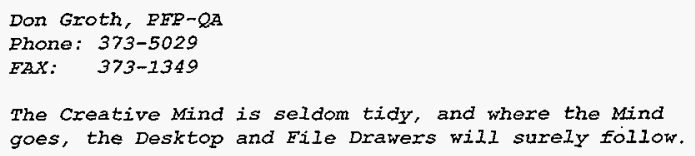




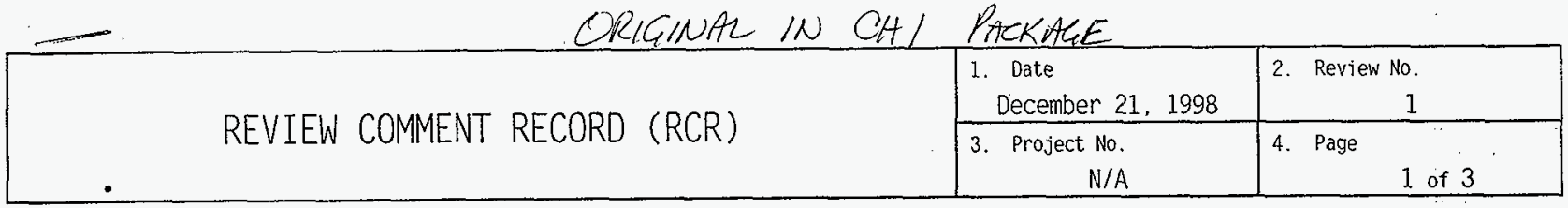

5. Document Number(s)/Tit $7 e(s)$

Final Safety Analysis Report (FSAR) HNF-SD-CP-SAR-021, Rev. 1

17. Comment Submittal Approval:

Organization Manager (optional)

ORIGINAL IN CH I PACKAGE 6. Program/Project/ Buit Tding Number

Plutonium

Finishing Plant (PFP) $01 / 07 / 99$

Date
7. Reviewer

DJ WIATRAK/FDH KH JATEN/FDH

\section{Organization/Group \\ OCCUPATIONAL SAFETY \& HEALTH}

9. Location/Phone 2355 Stevens Dr. 376-8805/373 9027

10. Agreement with indicated comment_dispgition(s)

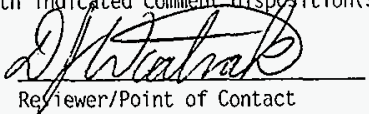
Resiewer/Point of Contact

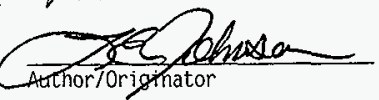

\section{CLOSEO $01 / 07 / 99$}

Date R
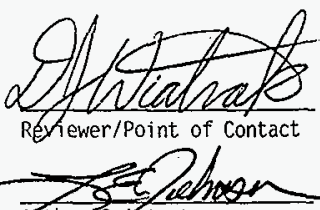
Author/originator

\begin{tabular}{l|l|l|l}
\hline \multirow{N}{*}{12.} & 13. Comment(s)/Discrepancy(s) (Provide technical justification & 14.
\end{tabular}

$\infty$ Ite for the comment and detailed recommendation of the action required Hold $\mathrm{m}$ to correct/ resolve the discrepancy/problem indicated.)

15. Disposition (Provide justification if NOT accepted.?

1. Chapter 4 - Section 4.4.8. Item 3, states that compressed gas system installations meet the requirements of WHC-CM-4-40 and WHC-CM-1-10. These two references are no longer applicable. A similar update is also needed in the References Section (Page R4-5).

2. Chapter 4 - The last sentence to Section 4.4.8, Item 10 , is missing an intended document reference.

3. Chapter 4 - Section 4.4 .8 fails to acknowledge that requirements are in place for design, operation, and maintenance of overhead cranes and hoists.

Changed text to met requirements and added that it meets requirements of HNF-PRO-087.

Point

|

It is a typo "tab" which left extra spaces:

Accept, added sentence to item \#12. 


\begin{tabular}{|l|l|l|}
\hline \multirow{2}{*}{ REVIEW COMMENT RECORD (RCR) } & $\begin{array}{l}\text { Date } \\
12 / 16 / 98\end{array}$ \\
\cline { 2 - 4 } & $\begin{array}{c}\text { 3. Project No. } \\
\text { PFPFSAR }\end{array}$ & $\begin{array}{l}\text { j. Page } \\
1 \text { of 2 } 2\end{array}$ \\
\hline
\end{tabular}

5. Document Number(s)/Title(s)

WHC-SD-CP-FSAR-021 Draft Rev. 1

Plutonium Finishing Plant Final

Safety Analysis Report, Chapter 4

\begin{tabular}{|l|l|l|l}
$\begin{array}{l}\text { 6. Program/Project/ } \\
\text { Building Number }\end{array}$ & 7. Reviewer & 8. Organization/Group & 9. Location/Phone \\
$\begin{array}{l}\text { PFP } \\
\text { Authorization } \\
\text { Basis }\end{array}$ & J.P. King & PFP Ops./15310 & 270-Z/373-5194 \\
\hline
\end{tabular}

17. Comment Submittal Approval:

10. Agreement with indicated comment disposition(s)

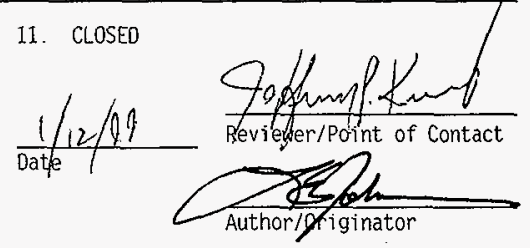
$1 / 12 / 6 ?$

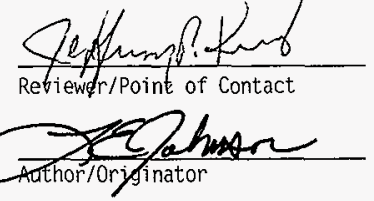

চ̛: 


\begin{tabular}{|c|c|c|}
\hline & $\begin{array}{l}\text { 1. Date } \\
12 / 16 / 98\end{array}$ & $\begin{array}{l}\text { 2. Review No. } \\
\text { jpk.ch4 }\end{array}$ \\
\hline W & $\begin{array}{r}\text { 3. Project No. } \\
\text { PFPFSAR }\end{array}$ & $\begin{array}{l}\text { 4. Page } 2 \text { of } 2 \\
\end{array}$ \\
\hline
\end{tabular}

\begin{tabular}{|c|c|c|c|c|}
\hline $\begin{array}{l}12 . \\
\text { Ite } \\
\text { m }\end{array}$ & $\begin{array}{l}\text { 13. Comment(s)/Discrepancy(s) (Provide technical justification } \\
\text { for the comment and detailed recommendation of the action required } \\
\text { to correct/ resolve the discrepancy/problem indicated.) }\end{array}$ & $\begin{array}{l}14 . \\
\text { Hoid } \\
\text { Point } \\
\end{array}$ & $\begin{array}{l}\text { 15. Disposition (Provide justification if NOT } \\
\text { accepted.) }\end{array}$ & $\begin{array}{l}16 . \\
\text { Statu } \\
\end{array}$ \\
\hline 幽 & $\begin{array}{l}\text { Page 4-23, 4.4.5.3, 2nd Para.: Paragraph is poorly } \\
\text { written, starts and ends with discussion of air } \\
\text { sampling systems but has criticality alarm system } \\
\text { stuck into the middle. Delete "other radiation } \\
\text { monitoring equipment" and move discussion of CAS. } \\
\text { starting with "Criticality Safety General } \\
\text { Requirements (HNF-PRO-334) to its own paragraph. } \\
\text { Place immediately after existing 3rd Para. } \\
\text { Also delete reference to Section } 8.3 .4 \text { and the CAS } \\
\text { in existing 3rd Para 4th Sentence. } \\
\text { Suggest: } \\
\text { "The criticality alarm system (CAS) radiation } \\
\text { detection equipment installation is based upon } \\
\text { American National Standards Institute } \\
\text { (ANSI)/American Nuclear Society (ANS) Standard } 8.3 \\
\text { as implemented by Criticality Safety General } \\
\text { Requirements (HNF-PRO-334). Definition and Means of } \\
\text { Maintaining the Criticality Detectors and Alarms } \\
\text { Portions of the PFP Safety Envelope (HNF-SD-CP-SDD- } \\
\text { 003). and Nuclear Alarm Manual for the Plutonium } \\
\text { Finishing Plant (HNF-IP-1115). See Chapter 8.0 } \\
\text { Section 8.3.4 for discussion of the CAS system." }\end{array}$ & & Text revisions made as recommended. & \\
\hline
\end{tabular}




\begin{tabular}{|c|c|c|c|c|}
\hline & 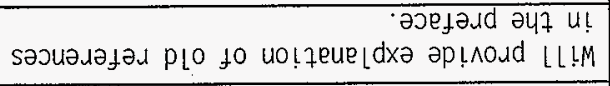 & & 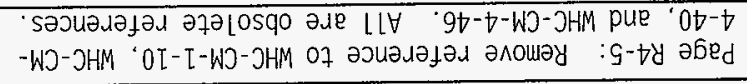 & $\varepsilon$ \\
\hline & 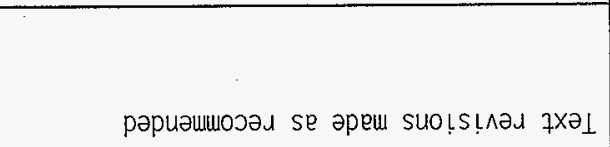 & & 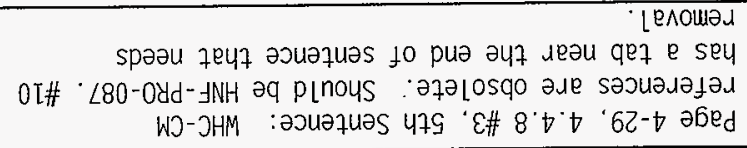 & 2 \\
\hline $\begin{array}{r}\mathbf{s} \\
n+3675 \\
9 L\end{array}$ & 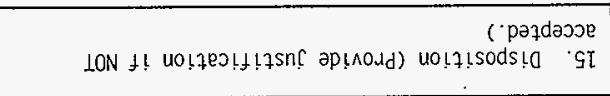 & $\begin{array}{l}74 ! \mathrm{Od} \\
\mathrm{PLOH} \\
.0 \mathrm{~T}\end{array}$ & 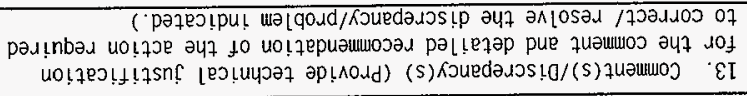 & $\begin{array}{r}\text { UI } \\
\partial q I \\
2 \mathrm{I}\end{array}$ \\
\hline
\end{tabular}

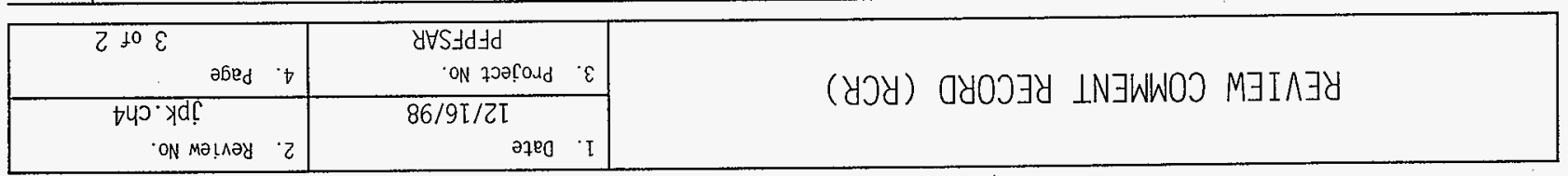




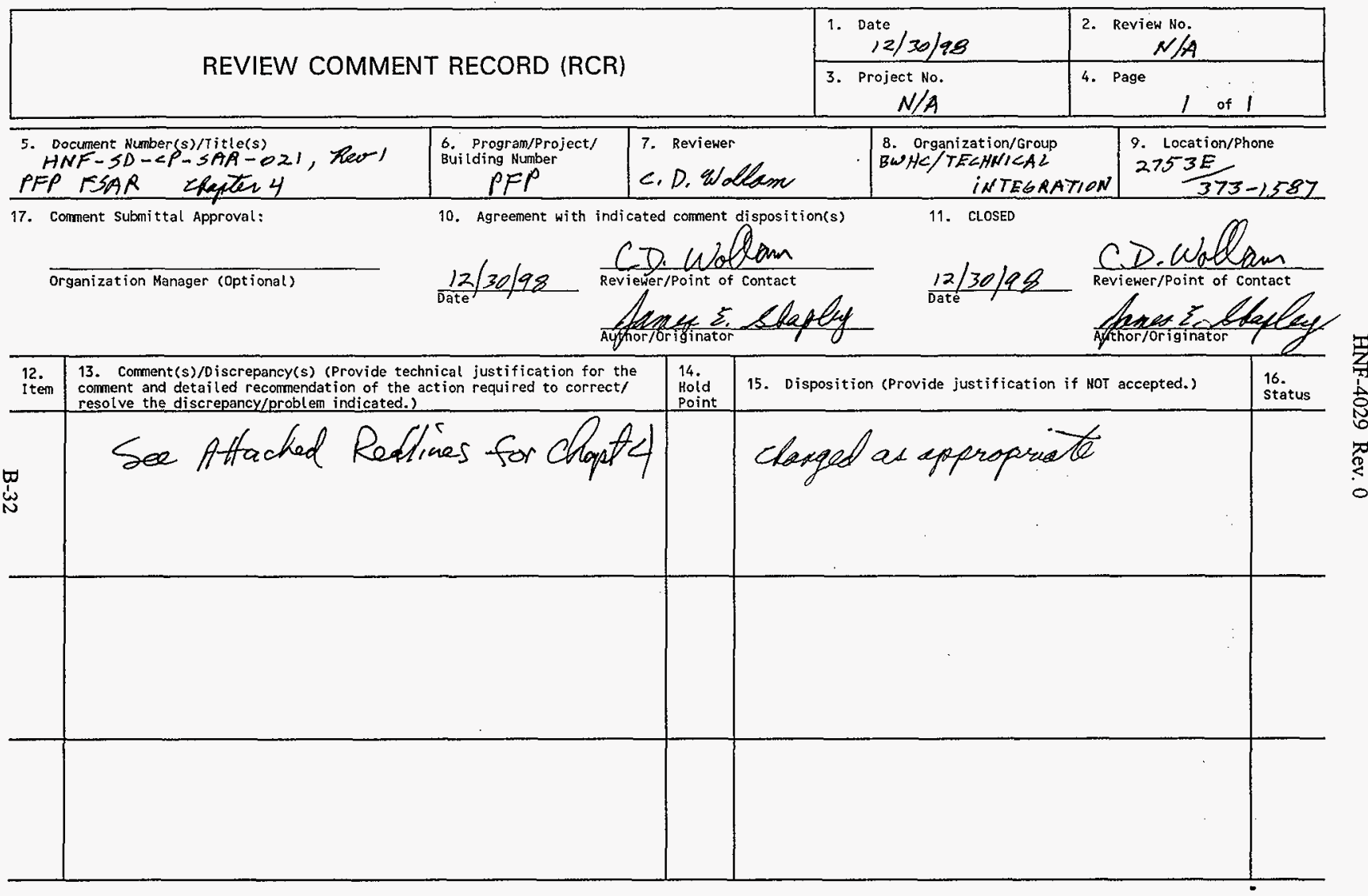

A-6400-090.1 (03/92) WEFC11 


\section{REVIEW COMMENT RECORD (RCR)}

\begin{tabular}{|c|l|}
\hline $\begin{array}{l}\text { 1. Date } \\
1 / 6 / 99\end{array}$ & $\begin{array}{l}\text { 2. Review No. } \\
4-4\end{array}$ \\
\hline $\begin{array}{c}\text { 3. Project No. } \\
\text { PFP FSAR }\end{array}$ & 4. Page \\
\hline
\end{tabular}

5. Document Number(s)/Titie(s)

HNF-SD-CP-SAR-021

17. Comment Submittal Approval:

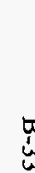

$\underset{\omega}{\omega}$

\begin{tabular}{|c|c|c|c|c|}
\hline \multirow[t]{2}{*}{$\begin{array}{l}12 . \\
\text { Ite } \\
\mathrm{m}\end{array}$} & $\begin{array}{l}\text { 13. Comment(s)/Discrepancy(s) (Provide technical justification } \\
\text { for the comment and detailed reconimendation of the action required } \\
\text { to correct/ resolve the discrepancy/problem indicated.) }\end{array}$ & $\begin{array}{l}14 . \\
\text { Hold } \\
\text { Point } \\
\end{array}$ & $\begin{array}{l}\text { 15. Disposition (Provide justification if NOT } \\
\text { accepted:) }\end{array}$ & $\begin{array}{l}16 . \\
\text { Statu } \\
\mathrm{s} \\
\end{array}$ \\
\hline & Chapter 4 comments & & & \\
\hline 1. & Redline markup of Chapter 4 received & & No comments submitted & \\
\hline \multicolumn{5}{|l|}{2.} \\
\hline \multicolumn{5}{|l|}{3.} \\
\hline \multicolumn{5}{|l|}{4.} \\
\hline & & & & \\
\hline & & & & \\
\hline & & & 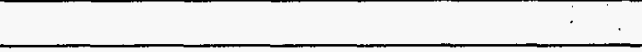 & \\
\hline & & & - & \\
\hline & & & & \\
\hline
\end{tabular}

\begin{tabular}{l|c} 
8. Organization/Group & 9. Location/Phone \\
PFP Transition \\
Operations
\end{tabular}

10. Agreement with indicated comment disposition(s)

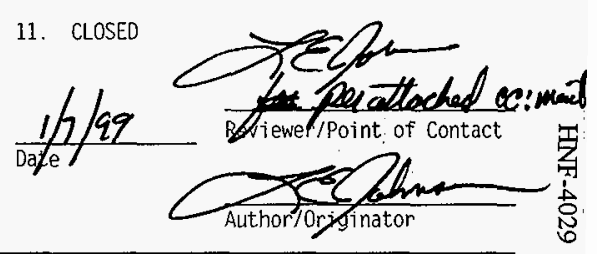

6. Program/Project/ Building Number

7. Reviewer

TA Brown

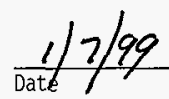

Rehewer/Point of contact

$\overline{\text { Organization Manager (Optional) }}$

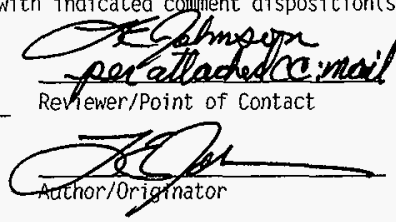

蛋

A-6400-090.1 (03/92) WEF011 


\section{Johnson, LE (Safety Analysis)}

From:

Sent:

To:

Subject:
Brown, Thomas A

Wednesday, January 06, 1999 4:00 PM

Johnson, LE (Safety Analysis)

RE: PFP FSAR Chapter 4 Review Comments

\section{----Original Message----- \\ From: Johnson, LE (Safety Analysis) \\ Sent: Wednesday, January 06, 1999 2:55 PM \\ To: Brown, Thomas A \\ Subject: PFP FSAR Chapter 4 Review Comments}

1 consider this item closed.

T.A. Brown

Tom,

You submitted a redline markup of chapter 4 . We couldn't find any redlines, but filled out a RCR for the record (see attached). If this is acceptable, please respond by cc:mail that you consider this RCR closed.

Thanks,

Larry Johnson

376-8807

《 File: TAB4DISP.RCR >> 


\begin{tabular}{|c|l|l|l|}
\hline \multirow{2}{*}{ REVIEW COMMENT RECORD (RCR) } & $\begin{array}{l}\text { 1. Date Review No. } \\
4-1\end{array}$ \\
\cline { 2 - 4 } & $\begin{array}{c}\text { 3. Project No. } \\
\text { PFP FSAR }\end{array}$ & $\begin{array}{l}\text { 4. Page } \\
1 \text { of 3: }\end{array}$ \\
\hline
\end{tabular}

\begin{tabular}{l|l|l|l|l}
\hline 5. Document Number(s)/Title(s) & $\begin{array}{l}\text { 6. Program/Project/ } \\
\text { Building Number } \\
\text { PFP FSAR }\end{array}$ & 7. Reviewer & 8. Organization/Group \\
DNF-SD-CP-SAR-021. Chapter 4 & PFP-QA
\end{tabular}

17. Comment Submittal Approval:

Organization Manager (Optional)

$\overline{\text { Organization Manager (optional) }}$

10. Agreement with indicated comment disposition(s)

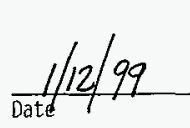

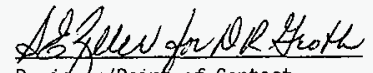
Reviewer/Poine of Contact

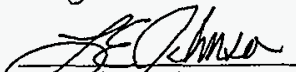

Author/originator
11. CLOSED

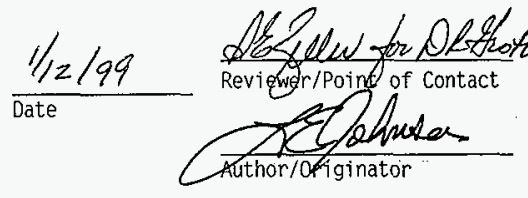

14.

山্山.

Ite for the comment and detailed recommendation of the action required

$\mathrm{m}$ to correct/ resolve the discrepancy/problem indicated.)

Comments taken from cc:mai 1, D Groth to Rammle \& Johnson. 12/17/98, "Comments on FSAR Chapter 4..."

1. There are many references, such as to WHC-CM-4-46 in Section 4.1. which no longer are(sic) in existence. Sometimes there is a Rev. number or year of issue associated with them. In the case of WHC_CM-4-46. there were probably several revisions use $\bar{d}$. Perhaps we should add a note to this effect somewhere up front, rather than leave this issue unaddressed or addressing it every time it comes up. A reference -4-46 also appears in Section 4.3.8.

\begin{tabular}{|l|l|l}
$\begin{array}{l}\text { 14. } \\
\text { Point }\end{array}$ & $\begin{array}{l}\text { 15. Disposition (Provide justification if NOT } \\
\text { accepted.) }\end{array}$ & $\begin{array}{l}16 . \\
\text { Statu } \\
\text { s }\end{array}$ \\
\hline & Accept, will explain in the preface. & \\
\hline
\end{tabular}




\begin{tabular}{|c|l|l|l|}
\hline \multirow{2}{*}{ REVIEW COMMENT RECORD (RCR) } & $\begin{array}{l}\text { 1. Date } \\
1 / 6 / 99\end{array}$ & $\begin{array}{l}\text { Review No. } \\
4-1\end{array}$ \\
\cline { 2 - 4 } & $\begin{array}{l}\text { 3. Project No. } \\
\text { PFP FSAR }\end{array}$ & 4. Page \\
2 of 3 \\
\hline
\end{tabular}

\begin{tabular}{|c|c|c|c|c|}
\hline $\begin{array}{l}12 . \\
\text { Ite } \\
m\end{array}$ & $\begin{array}{l}\text { 13. Comment(s)/Discrepancy(s) (Provide technical justification } \\
\text { for the comment and detailed recomendation of the action required } \\
\text { to correct/ resolve the discrepancy/problem indicated.) }\end{array}$ & \begin{tabular}{|l|}
14. \\
Hold \\
Point
\end{tabular} & $\begin{array}{l}\text { 15. Disposition (Provide justification if NOT } \\
\text { accepted.) }\end{array}$ & $\begin{array}{l}16 . \\
\text { Statu } \\
\text { s }\end{array}$ \\
\hline 2. & $\begin{array}{l}\text { A similar situation presents itself with safety } \\
\text { classifications. This has an additional } \\
\text { complication as illustrated in Section } 4.3 .5 .1 .1 \text { and } \\
4.3 .5 .1 .2 \text { (next to the last para) in which SC-1 and } \\
\text { SC-2 is presentes as being directly translated to SC } \\
\text { and SS, respectively. This is a common error. If } \\
\text { you compare this entry to Table } 4-4 \text { (page T4-4), } \\
\text { this is not how it is done. SC and SS is derived } \\
\text { from Table } 5 \text { of HNF-PRO-704, which is replicated as } \\
\text { FSAR Table } 4-4 \text {. Perhaps we need to remove reference } \\
\text { to SC-1. SC-2. SC-3 and "Non safety class SC- } 4 \text { " and } \\
\text { stay with the current system with some sort of } \\
\text { notation that SC and SS are derived different7y for } \\
\text { the SC-1. -2. and - } 3 \text { designations that appear in } \\
\text { much of the background documentation. This issue } \\
\text { a7so appears in Sections } 4.3 .6 \text { and } 4.3 .7 .1 \text {. }\end{array}$ & & $\begin{array}{l}\text { Will provide explanation in the preface. } \\
\text { For section 4.3.5.1.1, that is how they are } \\
\text { specified and there were no SC items in PFP } \\
\text { which were downgraded to SS. Para. } \\
4.3 .5 .1 .1 \text { and } 4.3 .5 .1 .2 \text { are talking about } \\
\text { application of seismic response spectra and } \\
\text { I think it sti77 applies as defined in the } \\
\text { para. However, determination of SC and SS } \\
\text { items is different per HNF-PRO-704 which waS } \\
\text { used for determination of SC and SS items. }\end{array}$ & \\
\hline 3. & $\begin{array}{l}\text { Near top of page } 4-21 \text { (Section } 4.4 .5 \text { ) makes } \\
\text { reference to "... Westinghouse Hanford Company...". } \\
\text { We could just replace that term with “...the } \\
\text { facility contractor's...". }\end{array}$ & & The text is revised as recommended. & \\
\hline 4. & $\begin{array}{l}\text { Para 4.5.3.3 (page 4-31). Probably OK as stated, } \\
\text { but "Approval Designators" are assigned for more } \\
\text { than those type of documents. }\end{array}$ & & No text revision made. & \\
\hline 5. & $\begin{array}{l}\text { Section } 4.5 .4 \text { (and again on page R4-4). WHC-SD-CP- } \\
017 \text { became "HNF-SD..." on November 10, } 1998 \text {. These } \\
\text { prefixes will continually be changed. }\end{array}$ & & Text changed to HNF. & \\
\hline
\end{tabular}




\section{REVIEW COMMENT RECORD (RCR)}

\begin{tabular}{|c|l|}
\hline $\begin{array}{c}\text { 1. Date } \\
1 / 6 / 99\end{array}$ & $\begin{array}{l}\text { 2. Review No. } \\
4-1\end{array}$ \\
\hline $\begin{array}{c}\text { 3. Project No. } \\
\text { PFP FSAR }\end{array}$ & 4. Page \\
\end{tabular}

\begin{tabular}{|c|c|c|c|c|}
\hline $\begin{array}{l}12 . \\
\text { Ite } \\
\text { m }\end{array}$ & $\begin{array}{l}\text { 13. Comment(s)/Discrepancy(s) (Provide technical justification } \\
\text { for the comment and detailed recommendation of the action required } \\
\text { to correct/ resolve the discrepancy/problem indicated.) }\end{array}$ & $\begin{array}{l}14 . \\
\text { Hold } \\
\text { Point }\end{array}$ & $\begin{array}{l}\text { 15. Disposition (Provide justification if NOT } \\
\text { accepted.) }\end{array}$ & $\begin{array}{l}16 . \\
\text { Statu } \\
5\end{array}$ \\
\hline 6. & $\begin{array}{l}\text { Pare R4-5. There are references to WHC-CM-1-10 and } \\
\text { WHC-CM-4-40. I don't believe that these appear in } \\
\text { the text (may do a word search to verify) and can be } \\
\text { deleted. WHC-CM-4-40 is referenced, and needs to } \\
\text { stay. }\end{array}$ & & Word search and replece was performed. & \\
\hline 7. & $\begin{array}{l}\text { Table 4-4 (and other tables): We may wish to } \\
\text { indicate which revision of which PRO this } \\
\text { replicates. This system (Impact Levels, SC-1, -2, - } \\
3 . . \text { ) Has tended to be revised frequently. }\end{array}$ & & No change will be made at this time. & \\
\hline & & & & \\
\hline & & & & \\
\hline & & & & \\
\hline & & & & \\
\hline & & & & \\
\hline & & & & \\
\hline & & & & \\
\hline & & & & \\
\hline & & & & \\
\hline
\end{tabular}




\section{REVIEW COMMENT RECORD (RCR)}

\begin{tabular}{|c|c|}
\hline 1. Date & 2. Review No. \\
$1 / 6 / 99$ & $5-4$ \\
\hline $\begin{array}{c}\text { 3roject No. } \\
\text { PFP FSAR }\end{array}$ & 4. Page 1 of 1 \\
\hline
\end{tabular}

5. Document Number(s)/Title(s)

HNF-SD-CP-SAR-021, Chapter 5

\begin{tabular}{l|l}
$\begin{array}{l}\text { 6. Program/Project/ } \\
\text { Building Number } \\
\text { PFP FSAR }\end{array}$ & 7. Reviewer \\
& RD Redekopp
\end{tabular}

6. Program/Project/ 7. Reviewer

PFP FSAR

10. Agreement with indicated comment disposition(s)

\section{TPRedeb.}

Reviewer/Point of Corftact

Organization Manager (optional)
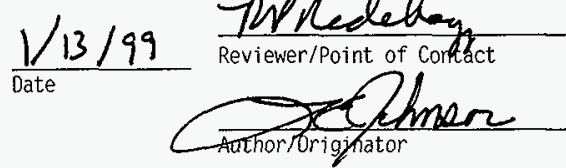

8. Organization/Group

PFP Operations
9. Location/Phone

11. CLOSED

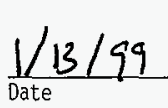

Nonveleh Reviewer/Point of Centact Date

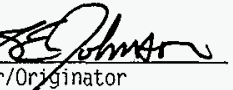

Author/0riginator

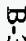

\begin{tabular}{|c|c|c|c|c|}
\hline $\begin{array}{l}12 . \\
\text { Ite } \\
\text { m }\end{array}$ & $\begin{array}{l}\text { 13. Comment }(s) / \text { Discrepancy }(s) \text { (Provide technical justification } \\
\text { for the comment and detailed recomendation of the action required } \\
\text { to correct/ resolve the discrepancy/problem indicated.) }\end{array}$ & $\begin{array}{l}14 . \\
\text { Hoid } \\
\text { Point }\end{array}$ & $\begin{array}{l}\text { 15. Disposition (Provide justification if NOT } \\
\text { accepted.) }\end{array}$ & $\begin{array}{l}16 . \\
\text { Statu } \\
5\end{array}$ \\
\hline & Chapter 5 & & & \\
\hline 1. & Comments on Chapter 5 received as redline markups. & & Comments incorporated as appropriate. & \\
\hline \multicolumn{5}{|l|}{2.} \\
\hline \multicolumn{5}{|l|}{3.} \\
\hline \multicolumn{5}{|l|}{4.} \\
\hline & & & & \\
\hline & & & & \\
\hline & & & & \\
\hline & & & & \\
\hline & & & & \\
\hline
\end{tabular}




\begin{tabular}{|c|l|l|}
\hline \multirow{2}{*}{ REVIEW COMMENT RECORD (RCR) } & $\begin{array}{l}\text { 1. Date } \\
1 / 6 / 99\end{array}$ & 2. Review No. \\
\cline { 2 - 4 } & $\begin{array}{c}\text { 3. Project No. } \\
\text { PFP FSAR }\end{array}$ & $\begin{array}{l}\text { 4. Page } \\
1 \text { of } 5\end{array}$ \\
\hline
\end{tabular}

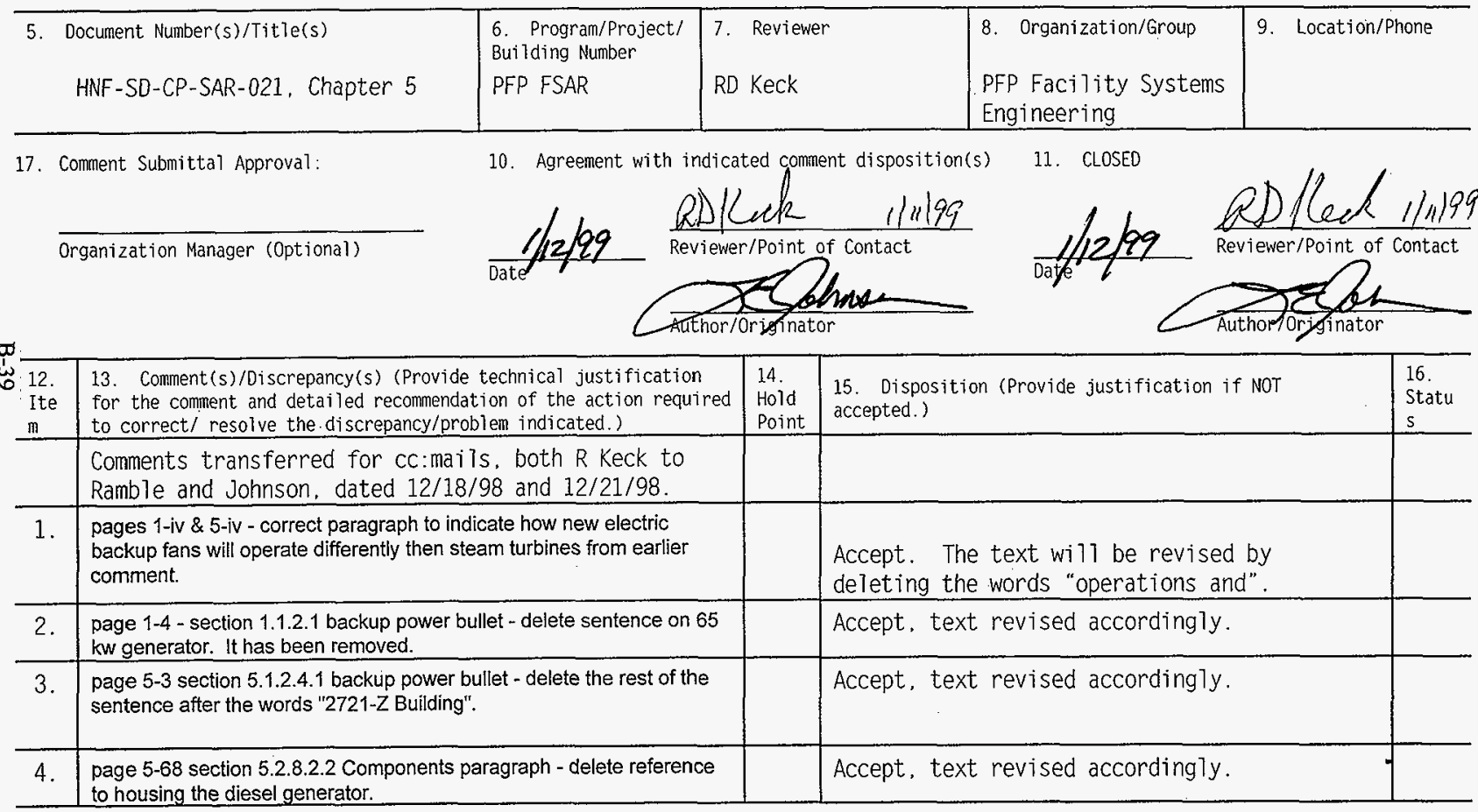




\begin{tabular}{|c|l|l|l|}
\hline \multirow{2}{*}{ REVIEW COMMENT RECORD (RCR) } & $\begin{array}{l}\text { 1. Date Review No. } \\
1 / 6 / 99\end{array}$ & \begin{tabular}{l} 
2. Re \\
\cline { 2 - 4 }
\end{tabular} & $\begin{array}{l}\text { 3. Project No. Page } \\
\text { PFP FSAR }\end{array}$ \\
\hline
\end{tabular}

\begin{tabular}{|c|c|c|c|c|}
\hline $\begin{array}{l}12 . \\
\text { Ite } \\
\text { m }\end{array}$ & $\begin{array}{l}\text { 13. Comment(s)/Discrepancy(s) (Provide technical justification } \\
\text { for the comment and detailed recommendation of the action required } \\
\text { to correct/ resolve the discrepancy/problem indicated.) }\end{array}$ & $\begin{array}{l}14 . \\
\text { Hold } \\
\text { Point }\end{array}$ & $\begin{array}{l}\text { 15. Disposition (Provide justification if NOT } \\
\text { accepted.) }\end{array}$ & $\begin{array}{l}16 . \\
\text { Statu } \\
s\end{array}$ \\
\hline 5. & $\begin{array}{l}\text { page } 5-73 \text { section } 5.2 .8 .7 \text { second paragraph - add a third dependency } \\
\text { for electric power from } 234-5 Z \text { and } 291-Z \text {. }\end{array}$ & & Accept, text revised accordingly. & \\
\hline 6. & $\begin{array}{l}\text { page } 5-84 \text { section } 5.4 .1 .1 .1 \text { Exhaust Fans paragraph - the dampers for } \\
\text { ef-1 and ef- } 2 \text { will be pneumatic with a separate accumulator and backup } \\
\text { air compressor to provide air when the instrument air system fails. Also } \\
\text { a switch will be added to allow either EF-3 or EF-4 to be a modulating } \\
\text { fan while the other fan is operated as a } 100 \% \text { fan. }\end{array}$ & & Accept, text revised according $7 y$. & \\
\hline 7. & $\begin{array}{l}\text { page } 5-87 \text { section } 5.4 .1 .1 .4 \text { last paragraph - add the following sentence } \\
\text { at the end of the paragraph. "The monitoring system alarms locally and } \\
\text { in room } 714 \text { (MICON power control room) of the } 234-5 Z \text { A Building." }\end{array}$ & & Accept, text revised accordingly. & \\
\hline 8. & $\begin{array}{l}\text { page } 5-89 \text { section } 5.4 .1 .1 .7 \text { second ventilation supply paragraph for } \\
2736-Z \text { - delete the last sentence. uninterruptible power is not supplied } \\
\text { to stack CAMs and sampling equipment. }\end{array}$ & & Accept, text revised accordingly. & \\
\hline 9. & $\begin{array}{l}\text { page } 5-90 \text { section } 5.4 .1 .1 .7 \text { paragraph on } 2736-Z A \text { building second } \\
\text { sentence - deiete the following "a } 65 \mathrm{~kW} \text { diesel generator that provides } \\
\text { backup power" and replace it with "controls". Add at the end of the } \\
\text { paragraph "Backup power for } 2736-Z A \text { equipment comes from the three } \\
2721-Z \text { diesel generators via MCC-EP-1 in } 2736-Z B \text {." }^{\prime}\end{array}$ & & Accept, text revised accordingly. & \\
\hline 10. & $\begin{array}{l}\text { page } 5-97 \text { section } 5.4 .1 .2 .4 \text { last paragraph second to last sentence - } \\
\text { replace "MICON control station in the } 234-5 Z \text { A Building" with " } 321 \mathrm{~A} \\
\text { power control room in the } 234-5 Z \text { Building" }\end{array}$ & & Accept, text revised accordingly. & \\
\hline 11. & $\begin{array}{l}\text { page 5-97 section } 5.4 .2 .1 \text { second paragraph third sentence - replace } \\
\text { "Two independent diesel generator stations" with "Three diesel } \\
\text { generator located in the } 2721-Z \text { Building" }\end{array}$ & & Accept, text revised accordingly. & \\
\hline 12. & $\begin{array}{l}\text { page } 5-98 \text { section } 5.4 .2 .1 .2 \text { last paragraph in the } 13.8 \mathrm{kV} \text {, line C } 8-\mathrm{L} 1 \\
\text { and } \mathrm{C} 8 \mathrm{-L} 2 \text { section first bullet - change "C5827F" with } \mathrm{C} 5874 \mathrm{P} \text { " }\end{array}$ & & Accept, text revised accordingly. & \\
\hline
\end{tabular}




\begin{tabular}{|c|l|l|l|}
\hline \multirow{2}{*}{ REVIEW COMMENT.RECORD (RCR) } & $\begin{array}{l}\text { Date } \\
1 / 6 / 99\end{array}$ & \begin{tabular}{l}
2. Review No. \\
\cline { 2 - 3 }
\end{tabular} & $\begin{array}{c}\text { Project No. } \\
\text { PFP FSAR }\end{array}$ \\
\hline
\end{tabular}

\begin{tabular}{|c|c|c|c|c|}
\hline $\begin{array}{l}12 . \\
\text { Ite } \\
m\end{array}$ & $\begin{array}{l}\text { 13. Comment }(s) / D i s c r e p a n c y(s) \text { (Provide technical justification } \\
\text { for the comment and detailed recommendation of the action required } \\
\text { to correct/ resolve the discrepancy/problem indicated.) }\end{array}$ & $\begin{array}{l}14 . \\
\text { Hold } \\
\text { Point }\end{array}$ & $\begin{array}{l}\text { 15. Disposition (Provide justification if NOT } \\
\text { accepted.) }\end{array}$ & $\begin{array}{l}16 . \\
\text { Statu } \\
\text { s } \\
\end{array}$ \\
\hline 13. & page $5-99$ section 5.4 .2 .1 .6 last line - add $2736-Z A$ prior to $2736-Z B$. & & Accept, text revised according Ty. & \\
\hline 14. & $\begin{array}{l}\text { page } 5-100 \text { section } 5.4 .2 .1 .7 \text { bullet for } 2736-Z A \text { - replace the paragraph } \\
\text { with the following "Normal electric power is supplied from } 13.8 \mathrm{kV} \text { line } \\
\text { (C8-L1) to a } 500-k V A, 13.8-k V \text { to } 480 / 277-V \text {, pad-mounted transformer } \\
\text { via panel NP-VF- located at the north end of } 2721-Z \text {. Backup power is } \\
\text { supplied from the three } 2721-Z \text { diesel generators via MCC-EP-1 in } \\
2736-Z B \text {." }\end{array}$ & & Accept, text revised accordingly. & \\
\hline 15. & page 5-101 section 5.4.2.1.9 - remove bullet for $65-\mathrm{kW}$ generator & & Accept, text revised accordingly. & \\
\hline 16 & $\begin{array}{l}\text { page } 5-101 \text { section } 5 \cdot 4 \cdot 2.1 .10 \text { first bullet - remove "emergency lighting" } \\
\text { from the third line }\end{array}$ & & Accept, text revised accordingly. & \\
\hline 17. & $\begin{array}{l}\text { page 5-101 section 5.4.2.1.10 second bullet second line - add "and } \\
2736-Z A^{\prime} \text { after "2736-ZB" }\end{array}$ & & Accept, text revised accordingly. & \\
\hline 18. & $\begin{array}{l}\text { page } 5-102 \text { section } 5 \cdot 4 \cdot 2.1 .10 \text { second to last paragraph - change "NP- } \\
\text { UF-1" to "NP-VF-1" }\end{array}$ & & Accept, text revised accordingly. & \\
\hline 19. & page 5-102 section 5.4.2.1.11 - delete paragraph & & Accept, text revised accordingly. & \\
\hline 20. & $\begin{array}{l}\text { page 5-102 section 5.4.2.1.12 - delete words between "291-Z Building;" } \\
\text { and "(see" and replace them with "evacuation sirens; and siren } \\
\text { controls" }\end{array}$ & & Accept, text revised accordingly. & \\
\hline 21. & $\begin{array}{l}\text { page 5-102 section } 5.4 .2 .1 .13 \text { - replace the words after "PFP" in the first } \\
\text { sentence with "to meet NFPA } 101 \text { requirements and to provide } \\
\text { additional lighting in areas not required by NFPA } 101 \text { to reduce safety } \\
\text { hazard to plant personnel." }\end{array}$ & & Accept, text revised accordingly. & \\
\hline
\end{tabular}




\begin{tabular}{|c|c|c|}
\hline \multirow{2}{*}{ REVIEW COMMENT RECORD (RCR) } & $\begin{array}{r}\text { 1. Date } \\
1 / 6 / 99 \\
\end{array}$ & 2. Review No. \\
\hline & $\begin{array}{l}\text { 3. Project No. } \\
\text { PFP FSAR }\end{array}$ & 4. Page \\
\hline
\end{tabular}

\begin{tabular}{|c|c|c|c|c|}
\hline $\begin{array}{l}12 . \\
\text { Ite } \\
\text { m }\end{array}$ & $\begin{array}{l}\text { 13. Comment(s)/Discrepancy(s) (Provide technical justification } \\
\text { for the comment and detailed recommendation of the action required } \\
\text { to correct/ resolve the discrepancy/problem indicated.) }\end{array}$ & $\begin{array}{l}14 . \\
\text { Hold } \\
\text { Point }\end{array}$ & $\begin{array}{l}\text { 15. Disposition (Provide justification if NOT } \\
\text { accepted.) }\end{array}$ & $\begin{array}{l}16 . \\
\text { Statu } \\
\text { S }\end{array}$ \\
\hline 22. & $\begin{array}{l}\text { page 5-103 section } 5.4 .2 .1 .14 \text { - } 232-Z \text { bullet - after "electrical power" } \\
\text { add "for ventilation and stack sampling/monitoring" }\end{array}$ & & Accept, text revised accordingly. & \\
\hline 23. & page 5-103 section 5.4.2.1.14 - delete $2736-Z$ A bullet & & Accept, text revised accordingly. & \\
\hline 24. & $\begin{array}{l}\text { page 5-105 section 5.4.2.2.2 second to last line of paragraph - after } \\
\text { "three automatic transfer switches" add ", MCC-EP-1 in 2736-ZB" }\end{array}$ & & Accept, text revised accordingly. & \\
\hline 25. & $\begin{array}{l}\text { page 5-106 section 5.4.2.2.7 third paragraph fourth line - replace "is } \\
\text { required to" with "will" }\end{array}$ & & Accept, text revised accordingly. & \\
\hline 26. & $\begin{array}{l}\text { page } 5-107 \text { section } 5.4 .2 .2 .9 \text { delete section - constant voltage } \\
\text { transformers are being removed due to most of them failing. }\end{array}$ & & Accept, text revised accordingly. & \\
\hline 27. & $\begin{array}{l}\text { page } 5-123 \text { section } 5.4 .10 .1 .2 \text { replace the fourth sentence with the } \\
\text { following: "The PAX switcher and public address systems are powered } \\
\text { by an uninterruptible power supply (UPS) located in room } 308 \text { of the } \\
234-5 Z \text { Building. In turn, the UPS is powered off the } 234-5 Z \text { emergency } \\
\text { bus by the } 2721-Z \text { diesel generators." }\end{array}$ & & Accept, text revised accordingly. & \\
\hline 28. & $\begin{array}{l}\text { page } 5-124 \text { section } 5.4 .10 .1 .3 \text { add siren located on the roof of } 2736-Z B \\
\text { to the list of sirens. }\end{array}$ & & Already covered by existing text. & \\
\hline 29. & $\begin{array}{l}\text { page 5-124 section 5.4.10.1.4 replace the section with the following: } \\
\text { "Emergency lighting in the PFP complex is provided by stand-alone } \\
\text { units located along evacuation routes as required by NPFA } 101 \text { and at } \\
\text { additional units located to reduce safety hazard to plant personnel. The } \\
\text { stand-alone units consist of incandescent lamps with a battery and } \\
\text { battery charger. The units are connected to the normal lighting circuits } \\
\text { and activate when power is lost to the normal lighting circuit." }\end{array}$ & & Accept, text revised accordingly. & \\
\hline
\end{tabular}




\begin{tabular}{|l|l|l|l|}
\hline \multirow{2}{*}{ REVIEW COMMENT RECORD (RCR) } & $\begin{array}{l}\text { 1. Date } \\
1 / 6 / 99\end{array}$ \\
\cline { 2 - 4 } & $\begin{array}{c}\text { 3. Project No. } \\
\text { PFP FSAR }\end{array}$ \\
\hline
\end{tabular}

\begin{tabular}{|c|c|c|c|c|}
\hline $\begin{array}{l}12 . \\
\text { Ite } \\
\mathrm{m}\end{array}$ & $\begin{array}{l}\text { 13. Comment(s)/Discrepancy(s) (Provide technical justification } \\
\text { for the comment and detailed recommendation of the action required } \\
\text { to correct/ resolve the discrepancy/problem indicated.) }\end{array}$ & $\begin{array}{l}14 . \\
\text { Hoid } \\
\text { Point }\end{array}$ & $\begin{array}{l}\text { 15. Disposition (Provide justification if NOT } \\
\text { accepted.) }\end{array}$ & $\begin{array}{l}16 . \\
\text { Statu } \\
\text { S }\end{array}$ \\
\hline 30. & $\begin{array}{l}\text { page } 5-125 \text { section } 5.4 .10 .1 .6 \text { second to last paragraph - delete the } \\
\text { following from the third sentence."(except the CAM associated with the } \\
296-Z-3 \text { stack)" }\end{array}$ & & Accept, text revised accordingly. & \\
\hline 31. & page $T 5-27$ - delete $2701-Z$ from the list. It has been removed. & & Accept, text revised accordingly. & \\
\hline 32. & $\begin{array}{l}\text { page T5-28 - } 2904-\mathrm{Z} \text { and } 2904-\mathrm{ZB} \text { - no longer do sampling. The } \\
\text { sampling is now done at } 225 \mathrm{WC} \text {. }\end{array}$ & & Accept, text revised accordingly. & \\
\hline 33. & $\begin{array}{l}\text { page } T 5-30 \text { - This analysis is not accurate but I do not have any } \\
\text { replacement figures. }\end{array}$ & & No change required. & \\
\hline 34. & $\begin{array}{l}\text { page T5-42 - The MICON system does not monitor any stack monitors. } \\
\text { The stack monitors annunciate on a hardwired annunciator located in } \\
\text { room } 714 \text { (MICON control room). }\end{array}$ & & Accept, text revised accordingly. & \\
\hline 35. & $\begin{array}{l}\text { page F5-17 - Remove ET- } 8 \text { and ET- } 9 \text { from the figure to be consistent } \\
\text { with showing the change from backup turbines to electrically backed up } \\
\text { fans. }\end{array}$ & & $\begin{array}{l}\text { A note has been added to the figure stating } \\
\text { that it needs to be updated for ET- } 8 \text { and ET- } \\
9 \text {. The figure cannot be revised at this } \\
\text { time. }\end{array}$ & \\
\hline 36. & $\begin{array}{l}\text { page 9-v-correct the statement relative to item } 8 \text {, changing from steam } \\
\text { turbines to electrically powered backup fans that the methods will } \\
\text { operate differently. }\end{array}$ & & Accept, text revised accordingly. & \\
\hline & & & & \\
\hline
\end{tabular}




\section{REVIEW COMMENT RECORD (RCR)}

\begin{tabular}{|c|c|}
\hline $\begin{array}{l}\text { 1. Date } \\
\qquad 1 / 6 / 99\end{array}$ & $\begin{array}{r}\text { 2. Review No. } \\
5-2\end{array}$ \\
\hline $\begin{array}{l}\text { 3. Project No. } \\
\text { PFP FSAR }\end{array}$ & 4. Page \\
\hline
\end{tabular}

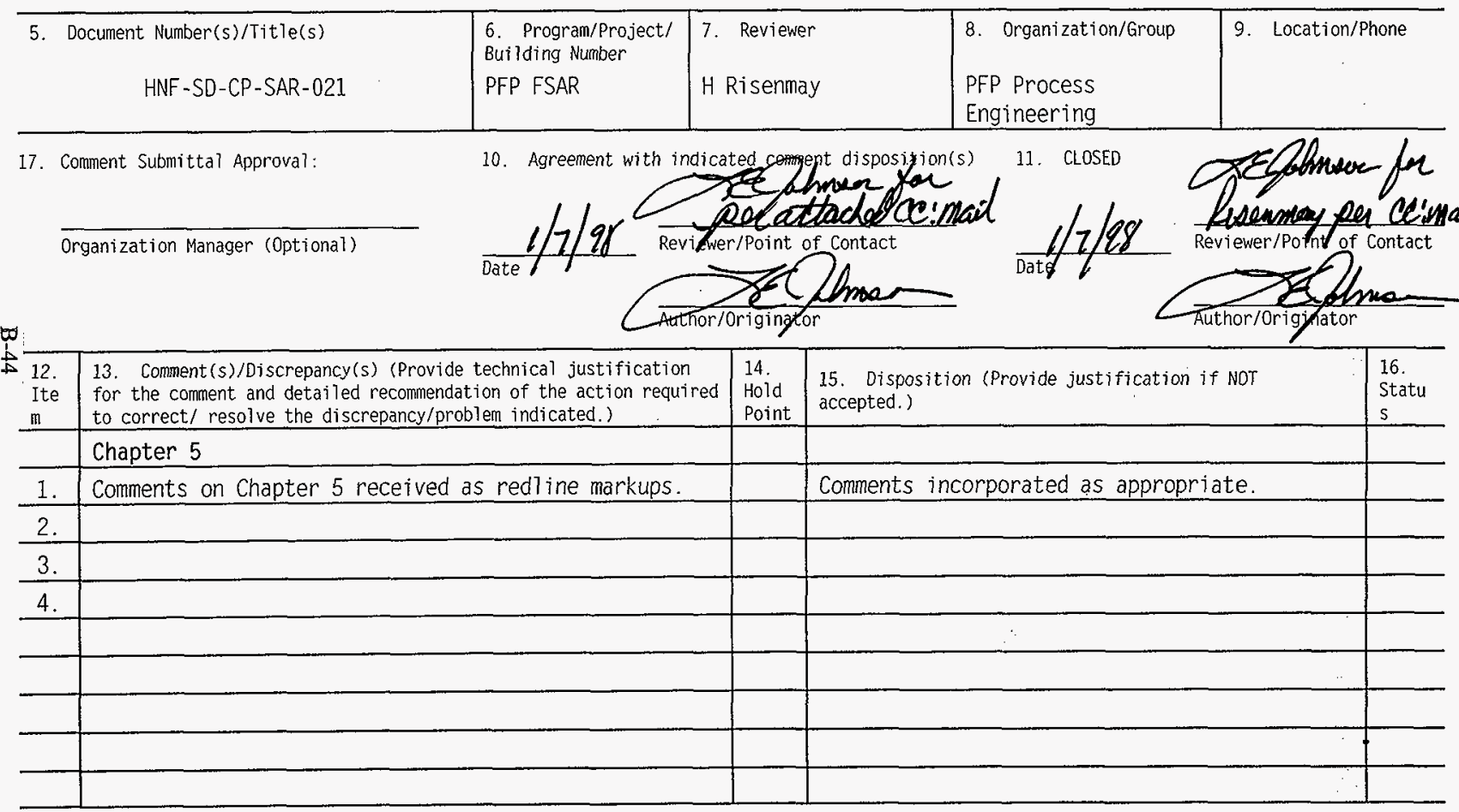


A. A

Johnson, L E (Safety Analysis)

From:

Sent:

To:

Risenmay, Howard R (Rees)

Thursday, January 07, 1999 7:01 AM

Johnson, LE (Safety Analysis)

RE: PFP FSAR chapter 6 comments

Larry,

1 accept the disposition and it its closed out.

HP. Qbees Qisenmay

PFP Process Engineering

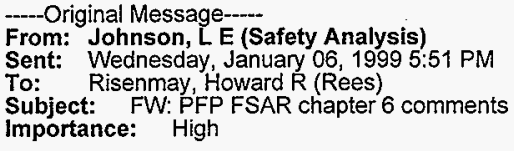

Rees,

Ditto on chapter 5 . See attached.

Larry

< File: HR5DISP.RCR $\gg>$

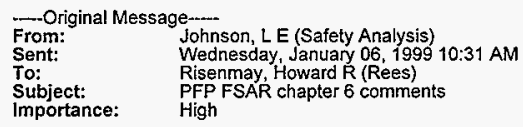

Rees,

You submitted redline markup comments on chapter 6 . Jim Shapley has incorporated them as appropriate. I've filled out a RCR form indicating this, see attached. If this is acceptable, please respond by cc:mail that you accept the disposition and that it is closed out.

Thanks,

Larry Johnson 


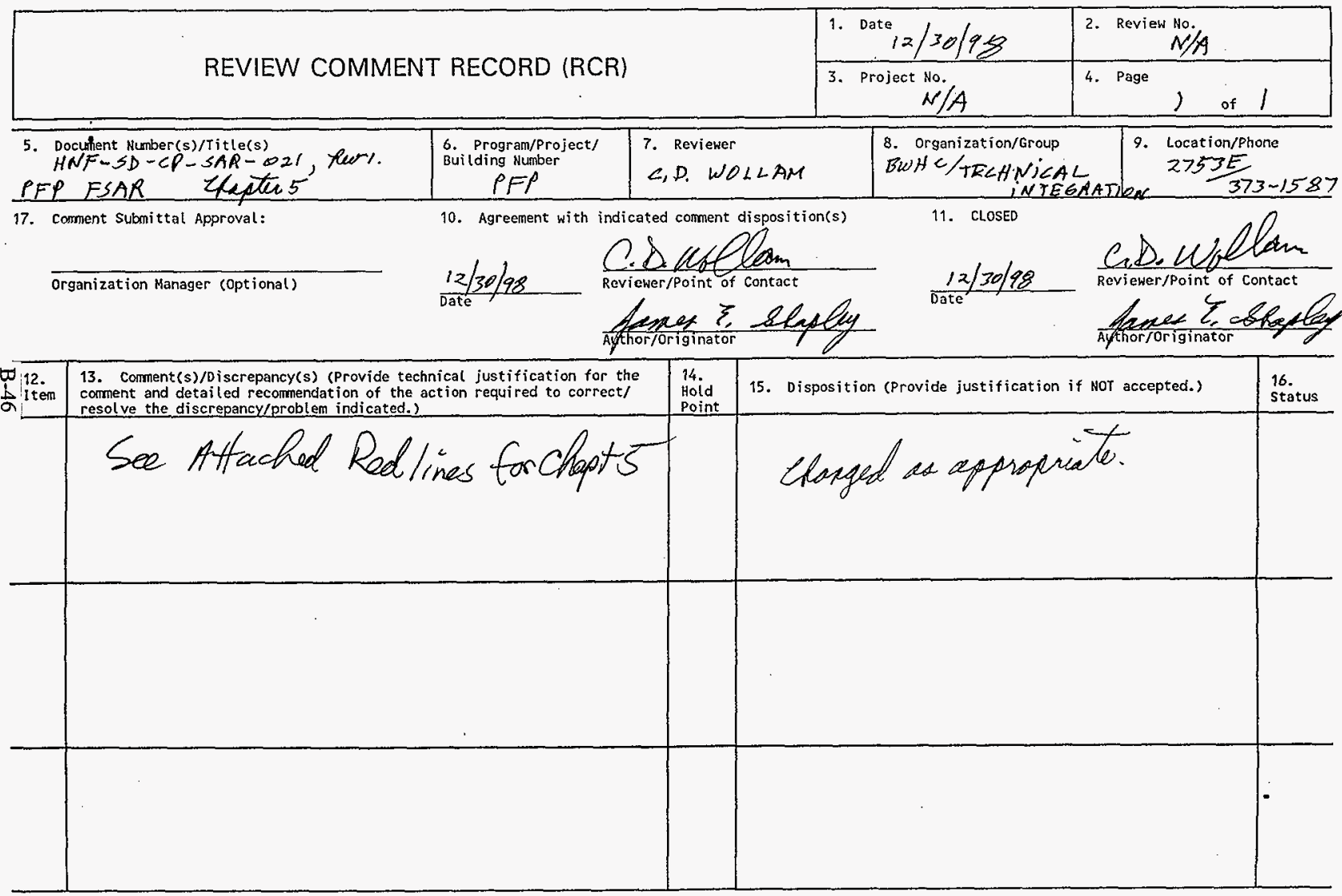




\section{REVIEW COMMENT RECORD (RCR)}

\begin{tabular}{|c|c|}
\hline $\begin{array}{c}\text { 1. Date } \\
12 / 30 / 98\end{array}$ & \begin{tabular}{l} 
2. Review No. $N / A$ \\
\hline 3. Project No. \\
$N / A$
\end{tabular} \\
\hline
\end{tabular}

\begin{tabular}{|c|c|c|}
\hline 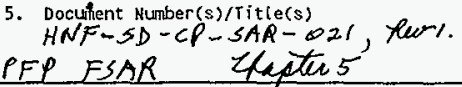 & $\begin{array}{l}\text { 6. Program/Project/ } \\
\text { Building Number } \\
\text { PFP }\end{array}$ & $\begin{array}{l}\text { 7. Reviewer } \\
\angle, D, \text { WOLLAM }\end{array}$ \\
\hline
\end{tabular}

8. Organization/Group

9. Location/Phone BWHC/TELH.NICAL $2753 E$

17. comment Submittal Approval:

10. Agreement with indicated comment disposition(s)
Organization Manager (Optional)

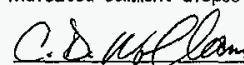

Reviewer/Point of contact
. Aunet ₹, Elopley

Authorioriginator sepley

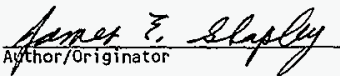

\section{t}

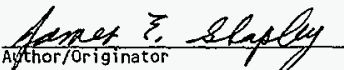

11. CLOSED INTEGAADLAS $373-1587$

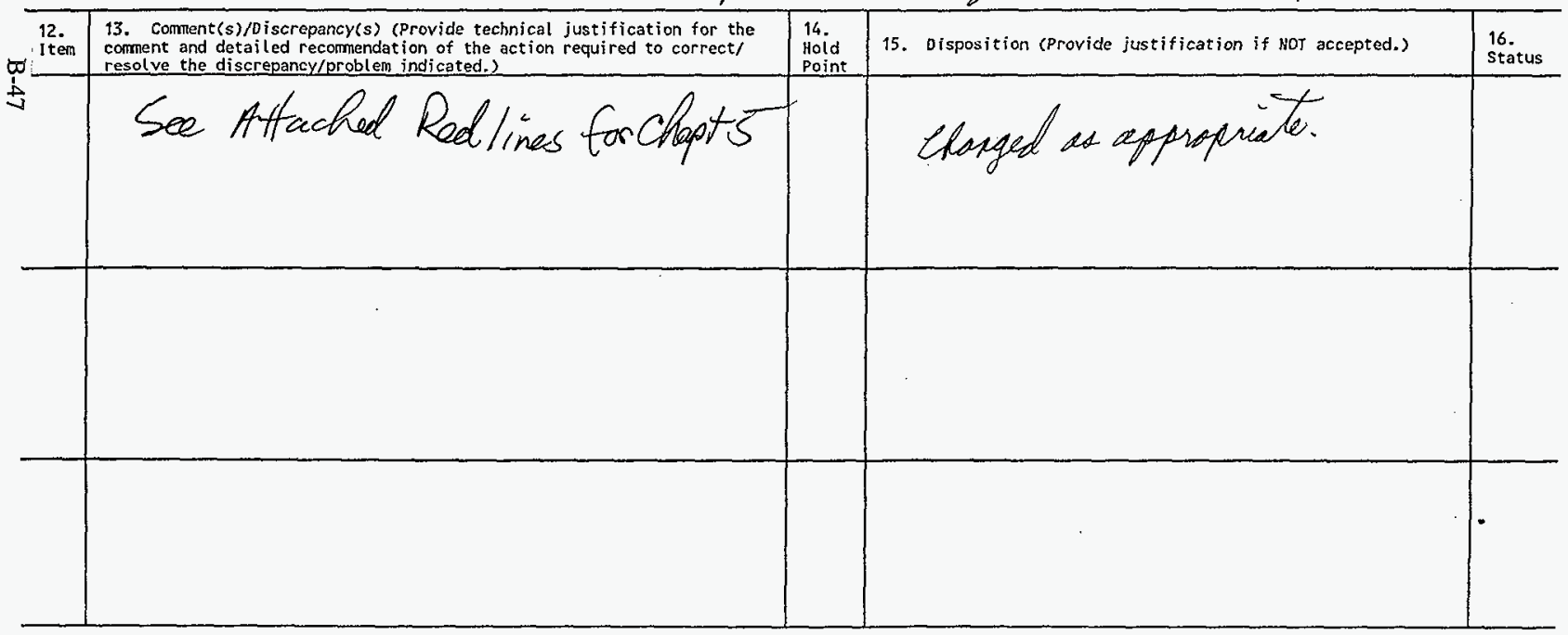




\section{REVIEW COMMENT RECORD (RCR)}

\begin{tabular}{|c|c|}
\hline 1. Date $12 / 30 / 90$ & 2. Review No. $N / A$ \\
\hline 3. Project No. & 4. Page $)$ \\
\hline
\end{tabular}

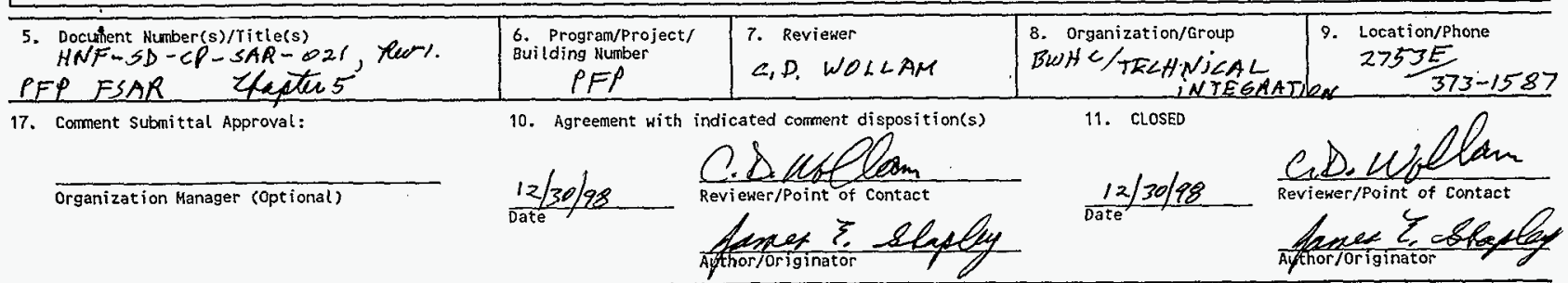

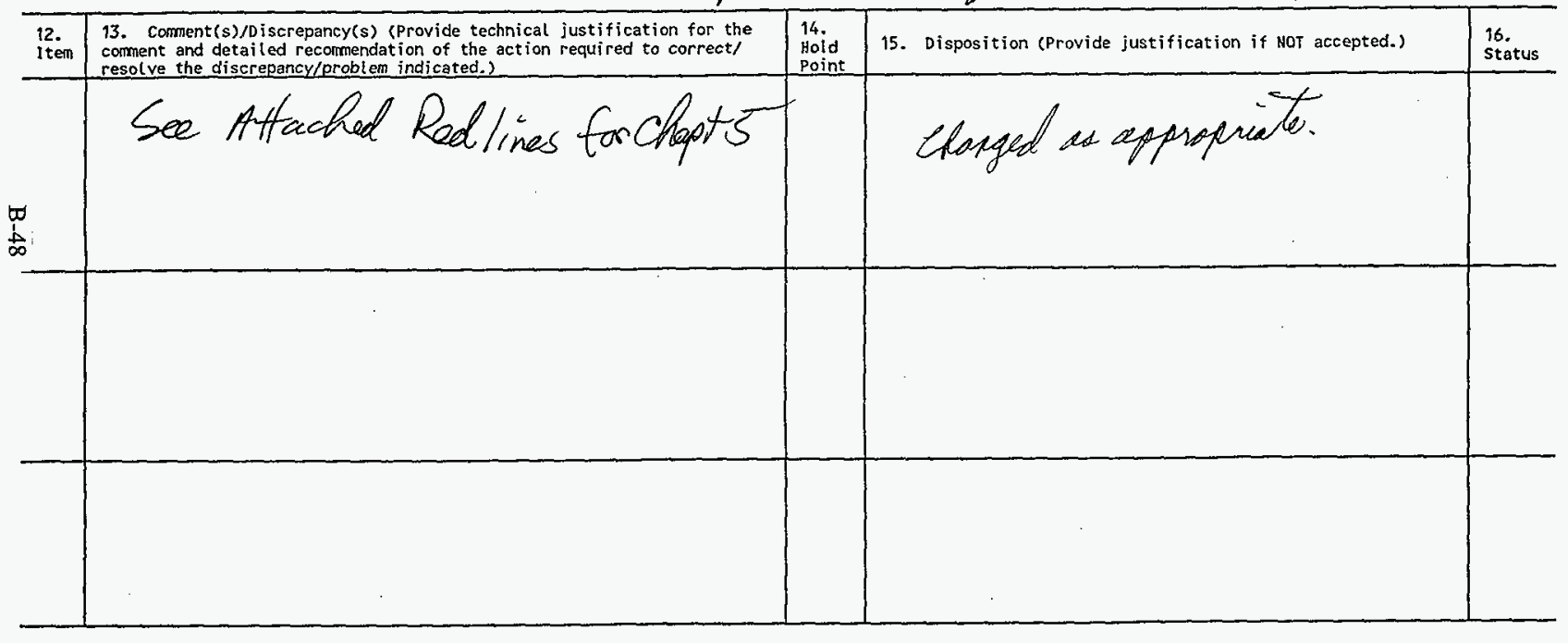




\section{REVIEW COMMENT RECORD (RCR)}

\begin{tabular}{|c|c|}
\hline $\begin{array}{l}\text { 1. Date } \\
1 / 6 / 99\end{array}$ & $\begin{array}{r}\text { 2. Review No. } \\
5-3\end{array}$ \\
\hline $\begin{array}{l}\text { 3. Project No. } \\
\text { PFP FSAR }\end{array}$ & 4. Page \\
\hline
\end{tabular}

5. Document Number(s)/Title(s)

HNF-SD-CP-SAR-021, Chapter 5

6. Program/Project/ Building Number

7. Reviewer

8. Organization/Group

9. Location/Phone

PFP FSAR

M Talbot

PFP Operations

17. Comment Submittal Approval:

10. Agreement with indicated comment dispgsition(s)

11. CLOSEO

Organization Manager (Optional)
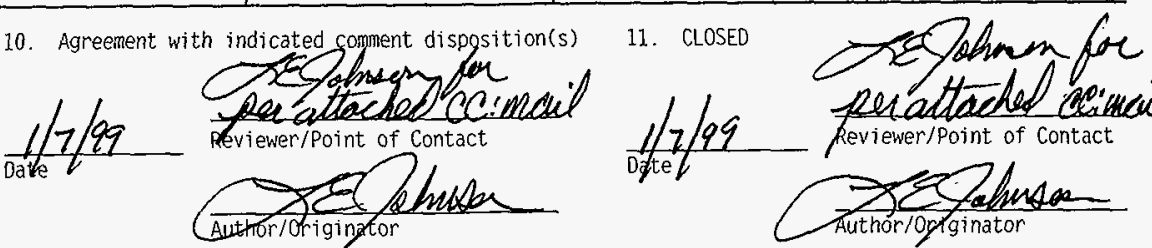
peratatedel carmeni

Reviewer/point of contact

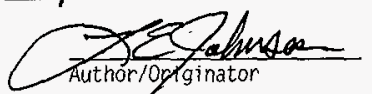

$\frac{1}{b}$

\begin{tabular}{|c|c|c|c|c|}
\hline \multirow[t]{2}{*}{$\begin{array}{l}12 . \\
\text { Ite } \\
\text { m }\end{array}$} & $\begin{array}{l}\text { 13. Comment(s)/Discrepancy ( } s \text { ) (Provide technical justification } \\
\text { for the comment and detailed recommendation of the action required } \\
\text { to correct/ resolve the discrepancy/problem indicated.) }\end{array}$ & $\begin{array}{l}14 . \\
\text { Hoid } \\
\text { Point }\end{array}$ & $\begin{array}{l}\text { 15. Disposition (Provide justification if NOT } \\
\text { accepted.) }\end{array}$ & $\begin{array}{l}16 . \\
\text { Statu } \\
\end{array}$ \\
\hline & Chapter 5 & & & \\
\hline 1. & Comments on Chapter 5 received as redi ine markups. & & Comments incorporated as appropriate. & \\
\hline \multicolumn{5}{|c|}{$\mathrm{C}_{\mathrm{C}} \mathrm{C}$} \\
\hline \multicolumn{5}{|l|}{3.} \\
\hline \multicolumn{5}{|l|}{4.} \\
\hline & & & & \\
\hline & & & & \\
\hline & & & & \\
\hline & & & $=$ & \\
\hline & & & & \\
\hline
\end{tabular}


From:

Talbot, Michael D (Mick)

Sent:

To:

Subject:

Thursday, Januany 07, 1999 5:13 PM

Johnson, LE (Safety Analysis)

RE: PFP FSAR Chapter 5 Comments

Larry,

I concur for both chapters.

Mick

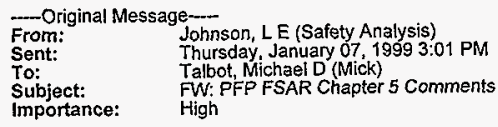

Mick,

Ditto for the Chapter 1 RCR.

Larry Johnson

« File: MDT1DISP.RCR 》>

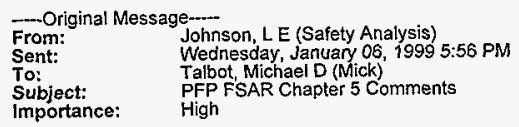

Mick,

You submitted redline comments on Chapter 5. Jim Shapley has incorporated them as appropriate. I've filled out a RCR form indicating this, please see attached. If this is acceptable, please respond by cc;mail that you accept the disposition and consider the RCR closed.

Thanks,

Larry Johnson

376-8807

« File: MDT5DISP.RCR $\gg$ 


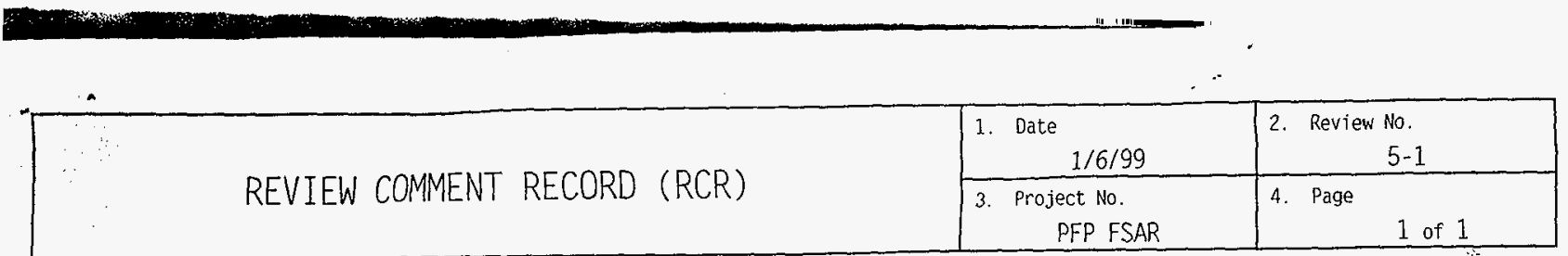

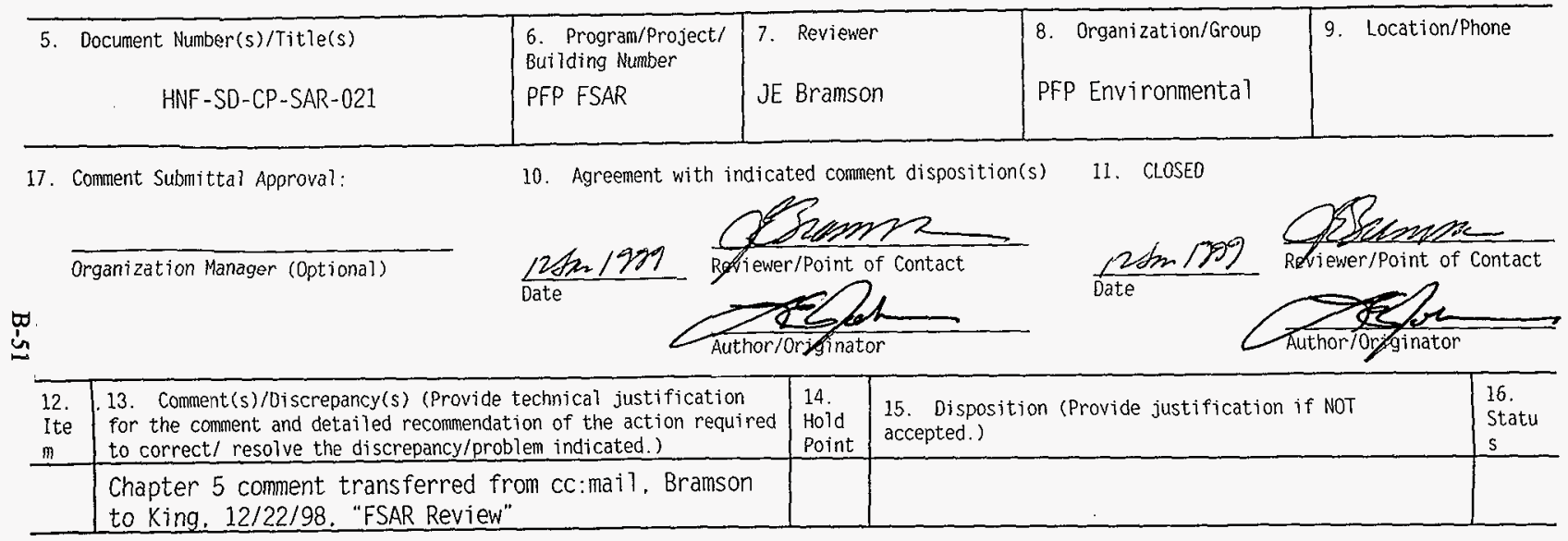


-

.

\section{REVIEW COMMENT RECORD (RCR)}

\begin{tabular}{|l|l|}
\hline $\begin{array}{c}\text { 1. Date } \\
1 / 6 / 99\end{array}$ & 2. Review No. \\
\hline $\begin{array}{c}\text { 3. Project No. } \\
\text { PFP FSAR }\end{array}$ & 4. Page 1 of 1 \\
\hline
\end{tabular}

5. Document Number(s)/Title(s)

HNF-SD-CP-SAR-021

\begin{tabular}{l|ll}
$\begin{array}{l}\text { 6. Program/Project/ } \\
\text { Building Number } \\
\text { PFP FSAR }\end{array}$ & J. Reviewer \\
& JE Bramson
\end{tabular}

8. Organization/Group

9. Location/Phone

10. Agreement with indicated comment disposition(s)

11. CLOSED

17. Comment Submittal Approval:

PFP Environmenta?

Organization Manager (Optional)

\section{$128 x_{2} 1989$}



Date

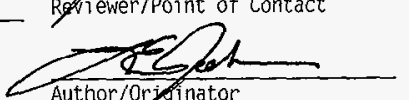

$2 \sin 1799$

Date

Rdiewer/Point of contact

岕.

Author/0risinator

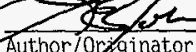

Author/orzatinator

\begin{tabular}{l|l|l|l|l}
$\begin{array}{l}\text { 12. } \\
\text { Ite }\end{array}$ & $\begin{array}{l}\text { 13. Comment(s)/Discrepancy(s) (Provide technical justification } \\
\text { for the comment and detailed recommendation of the action required } \\
\text { to correct / resolve the discrepancy/problem indicated.) }\end{array}$ & $\begin{array}{l}14 . \\
\text { Hold } \\
\text { Point }\end{array}$ & $\begin{array}{l}\text { 15. Disposition (Provide justification if Not } \\
\text { accepted.) }\end{array}$ & $\begin{array}{l}\text { Statu } \\
\text { s }\end{array}$ \\
\hline & $\begin{array}{l}\text { Chapter } 5 \text { comment transferred from cc:mail. Bramson } \\
\text { to King. 12/22/98, "FSAR Review" }\end{array}$ & & & \\
\hline
\end{tabular}




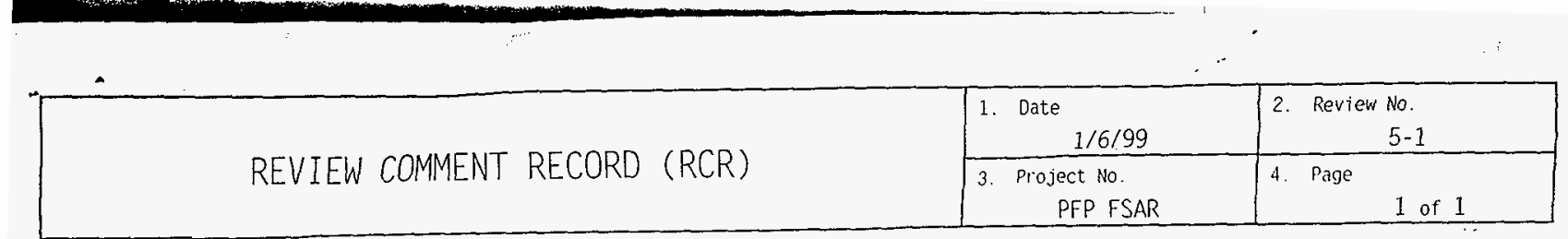

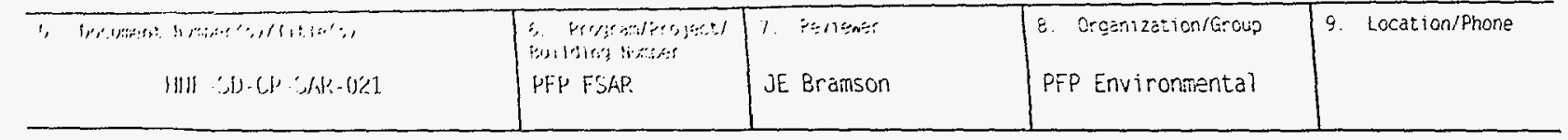

17. Comment Subsittal Approval:

Organization Manager (Optional)

in

w12. 13. Comment(s)/Discrepancy(s) (Provide technical justification

Ite for the comment and detailed recommendation of the action required

$m$ to correct/ resolve the discrepancy/problem indicated.)

Chapter 5 comment transferred from cc:mail, Bramson

to King, 12/22/98. "FSAR Review"
10. Agreement with indicated coment disposition(s)

11. CLOSEO

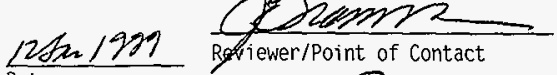
Date

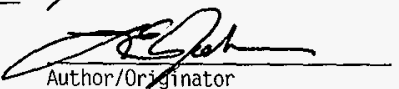
Date

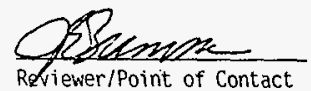
26209 RQviewer/Point of Contact

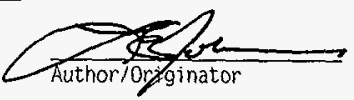
Author/Orjginator 


\begin{tabular}{|c|l|l|l|}
\hline \multirow{2}{*}{ REVIEW COMMENT RECORD (RCR) } & $\begin{array}{l}\text { 1. Date } \\
1 / 6 / 99\end{array}$ & $\begin{array}{c}2 . \text { Review No. } \\
5-1\end{array}$ \\
\cline { 2 - 5 } & $\begin{array}{c}\text { 3. Project No. } \\
\text { PFP FSAR }\end{array}$ & 4. Page \\
\hline
\end{tabular}

12 13. Comment(s)/0iscrepancy(s) (Provide technical justification

Ite for the comment and detailed recommendation of the action required

$\mathrm{m}$ to correct/ resolve the discrepancy/problem indicated.)

1. Page 5-149. Section 5.4.13.6, second paragraph.

Re: sentence beginning. "Before any waste from a

spi71..." Revise to read. "Before authorization is

given to dispose of wastes generated from spill

response actions to the wastewater effluent stream,

process engineering, environmental compliance, and

plant management, interfacing with solid waste

engineering, shall determine whether the waste is

regulated."

Re: last sentence. Revise to read, "Release/spill

罗

notification and reporting is performed in

is accordance with applicable federal, state, and local regulations and DOE Orders."

14.
Hold
Point

15. Disposition (Provide justification if NOT

Accept, text revised as requested.

\begin{tabular}{l|l|} 
& regulations and DOE Orders." \\
\hline 2. & \\
\hline 3. & \\
\hline 4. & \\
\hline
\end{tabular}

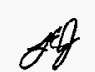

Accept, text revised as requested. 


\begin{tabular}{|c|c|c|}
\hline & $\begin{array}{l}\text { 1. Date } \\
1 / 6 / 99\end{array}$ & 2. Review No. \\
\hline REV IEW & $\begin{array}{l}\text { 3. Project No. } \\
\text { PFP FSAR }\end{array}$ & 4. Page 1 of 2 \\
\hline
\end{tabular}

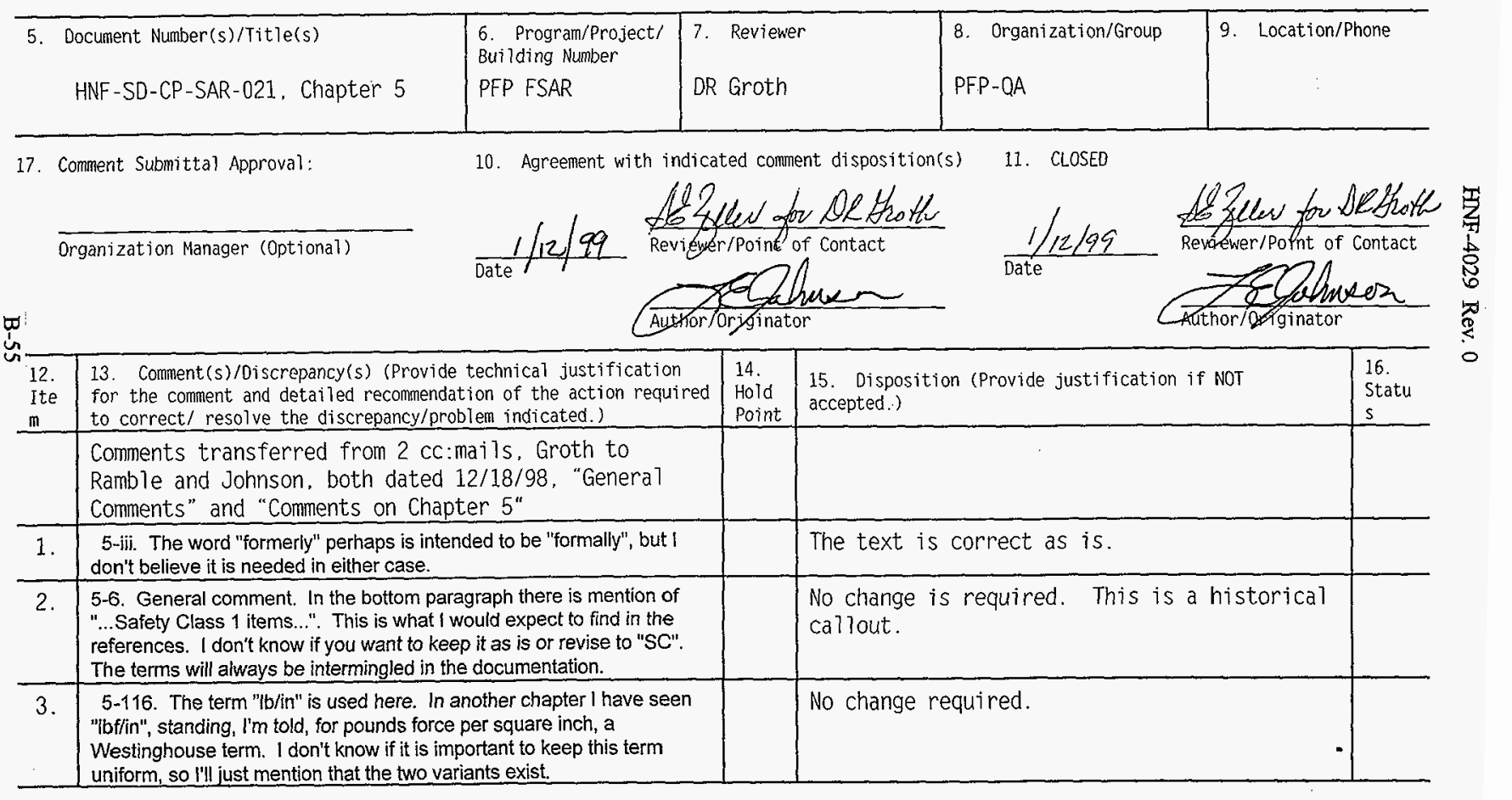




\section{REVIEW COMMENT RECORD (RCR)}

\begin{tabular}{|c|l|}
\hline $\begin{array}{l}\text { 1. Date } \\
1 / 6 / 99\end{array}$ & 2. Review No. \\
\hline $\begin{array}{c}\text { 3. Project No. } \\
\text { PFP FSAR }\end{array}$ & 4. Page 2 of 2 \\
\hline
\end{tabular}

\begin{tabular}{|c|c|c|c|c|}
\hline $\begin{array}{l}12 . \\
\text { Ite } \\
\text { fif }\end{array}$ & $\begin{array}{l}\text { 13. Comment(s)/Discrepancy(s) (Provide technical justification } \\
\text { for the comment and detailed recommendation of the action required } \\
\text { to correct/ resolve the discrepancy/problem indicated.) }\end{array}$ & $\begin{array}{l}14 . \\
\text { Hoid } \\
\text { Point }\end{array}$ & $\begin{array}{l}\text { 15. Disposition (Provide justification if NOT } \\
\text { accepted.) }\end{array}$ & $\begin{array}{l}16 . \\
\text { Statu } \\
\$\end{array}$ \\
\hline 4. & $\begin{array}{l}\text { R5-1 and R5-3: The term "Babcock and Wilcox Hanford Company" } \\
\text { appears twice on page R5-1. The term "Babcock and Wilcox Hanford" } \\
\text { appears on page R5-3. Both should be "B\&W Hanford Company". }\end{array}$ & & Accept, text revised accordingly. & \\
\hline 5. & R5-5. WHC-SD-CP-108 became HNF-SD-CP-108 last month. & & Accept, text revised accordingly. & \\
\hline 6. & $\begin{array}{l}\text { The temperature for processing Oxide, and performing the LOI, has } \\
\text { been changed from } 950 \text { to } 1000^{\circ} \mathrm{C} \text {. I believe that I have seen the } \\
\text { number } 950^{\circ} \mathrm{C} \text { in some part of the text I have reviewed, but cannot now } \\
\text { find it. Suggest that a word search for " } 950^{\prime \prime} \text { be made in chapters } 4 \text { and } \\
10 .\end{array}$ & & $\begin{array}{l}\text { Accept, a search was performed on chpaters } \\
4,5, \& 6 \text {. }\end{array}$ & \\
\hline & & & & \\
\hline & & & & \\
\hline & & & & \\
\hline & & & & \\
\hline & & & & \\
\hline & & & & \\
\hline & & & & \\
\hline
\end{tabular}




\section{REVIEW COMMENT RECORD (RCR)}

\begin{tabular}{|l|l|}
\hline \multicolumn{1}{|l|}{ Date $12 / 21 / 98$} & 2. Revi ew No. \\
\hline 3. Project No. & 4. Page $\quad 1$ of 3 \\
\hline
\end{tabular}

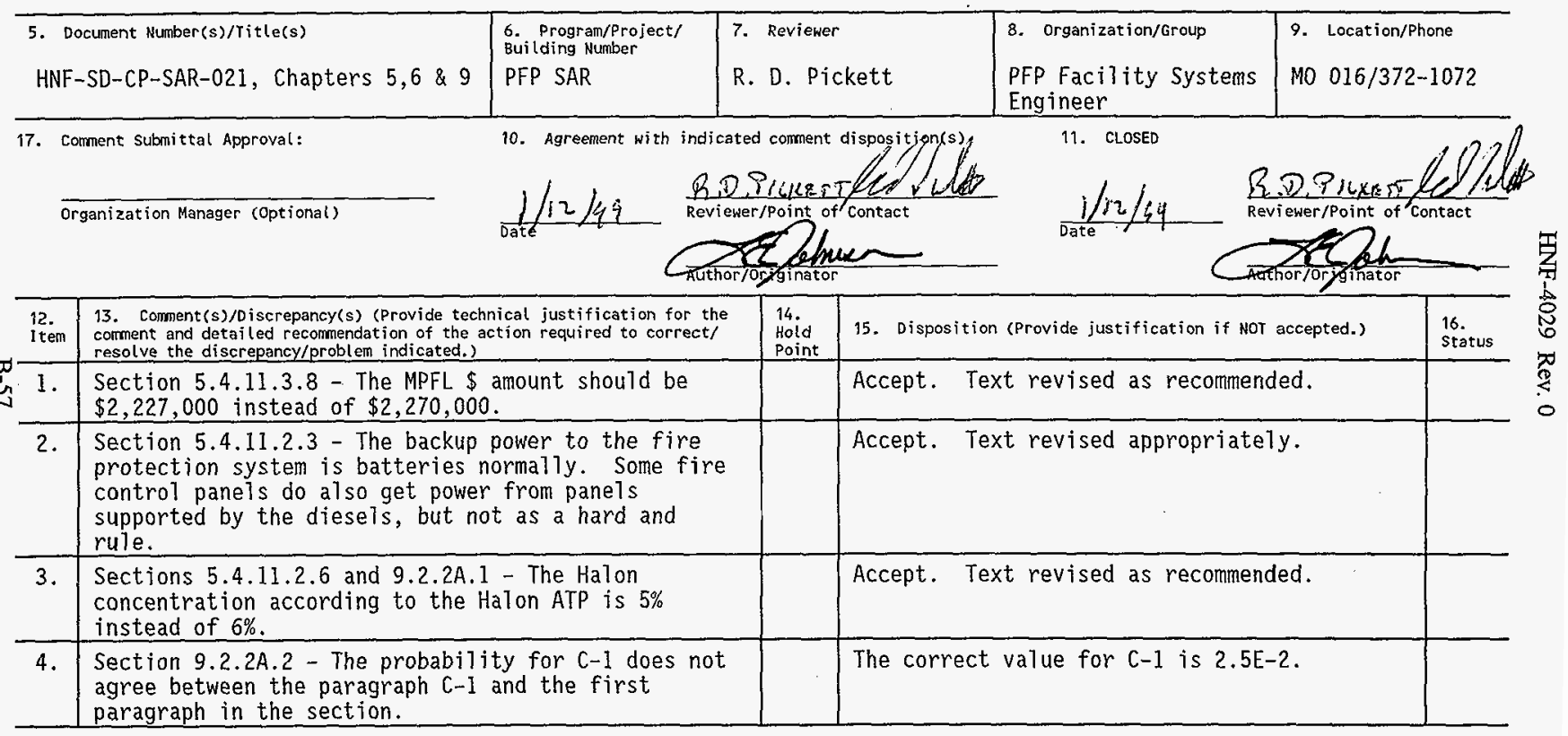




\begin{tabular}{|l|l|l|l|}
\hline \multirow{2}{*}{ REVIEW COMMENT RECORD (RCR) } & 1. Date & 12/21/98 Review No. \\
\cline { 2 - 3 } & 3. Project No. & 4. Page \\
\hline
\end{tabular}

\begin{tabular}{|c|c|c|c|c|}
\hline $\begin{array}{l}12 . \\
\text { Item }\end{array}$ & $\begin{array}{l}\text { 13. Comment(s)/Discrepancy(s) (Provide technical justification for the } \\
\text { comment and detailed recommendation of the action required to correct/ } \\
\text { resolve the discrepancy/problem indicated.) }\end{array}$ & $\begin{array}{l}14 . \\
\text { Hold } \\
\text { Point }\end{array}$ & 15. Disposition (Provide justification if Nor accepted.) & $\begin{array}{l}16 . \\
\text { status }\end{array}$ \\
\hline 5. & $\begin{array}{l}\text { Section } 9.2 .2 A .2 \text { - The probability for } D-1 \text { is } \\
\text { missing from the first paragraph. }\end{array}$ & & $\begin{array}{l}\text { Text revised to state "People fail to take } \\
\text { proper action following ignition - } 2 \text {.1E- } \\
1 \text { /demand (fire not noticed or corrected)." } \\
\text { Note that D-1 and D-2 are under an "or" gate } \\
\text { and thus the values are added }(.2+.01= \\
2.1 E-1)\end{array}$ & \\
\hline 6. & $\begin{array}{l}\text { Section } 9.2 .2 A .2 \text {, paragraph } C-6 \text { - The fire alarms } \\
\text { are not connected to the MICON. They currently } \\
\text { a arm at the Flex } 500 \mathrm{~A} \text { panel and are transmitted to } \\
\text { the fire department. Only the } 2736-\mathrm{B} \text { fire alarm is } \\
\text { connected to the MICON. }\end{array}$ & & $\begin{array}{l}\text { Text revised to state "Building } 234-52 \text { fire } \\
\text { alarms alarm at the Flex } 500 \mathrm{~A} \text { pane } 1 . . . \text { " }\end{array}$ & \\
\hline 7. & $\begin{array}{l}\text { Section } 9.2 .2 B .2 \text { - Where did the volume of } 340 \\
\text { gallons for the dike come from? The only number I } \\
\text { have seen was } 170 \text { gallons. }\end{array}$ & & $\begin{array}{l}\text { The berm is reported to be } 13 \mathrm{ft} \text { by } 7 \mathrm{ft} \text { by } \\
6 \text { inches. The associated volume is } 340 \text {. I } \\
\text { am not positive, but most berms are suppose } \\
\text { to hold twice the volume potentially } \\
\text { spilled. The } 340 \text { number makes sense as the } \\
\text { FHA assumes a spill of } 150 \text { gallions. }\end{array}$ & \\
\hline 8. & $\begin{array}{l}\text { Section } 9.2 .2 B .2 \text { - While the sprinklers do mitigate } \\
\text { a little, couid we add a phrase which states we do } \\
\text { not take credit for the sprinklers in the accident } \\
\text { analysis. This would eliminate any questions } \\
\text { whether the sprinklers are safety significant or } \\
\text { general service. The sprinklers are currently } \\
\text { general service and I would like to keep it that } \\
\text { way. }\end{array}$ & & $\begin{array}{l}\text { Text changed to state: Although not } \\
\text { specifically credited with preventing } \\
\text { collapse of the roof, the hot pipe sprinkler } \\
\text { system also provides mitigation in the event } \\
\text { of a hydraulic oil fire. }\end{array}$ & \\
\hline 9. & $\begin{array}{l}\text { Section } 6.4 .1 .4 .4 \text {, paragraph Industrial Safety - } \\
\text { Gloveboxes have heat detectors only, no combustion } \\
\text { detectors. }\end{array}$ & & Deleted reference to combustion detectors. & \\
\hline
\end{tabular}




\begin{tabular}{|c|c|c|c|c|c|}
\hline \multirow{2}{*}{\multicolumn{3}{|c|}{ REVIEW COMMENT RECORD (RCR) }} & \multirow{2}{*}{\begin{tabular}{|l|l|} 
1. Date & $12 / 21 / 98$ \\
3. Project No.
\end{tabular}} & \multicolumn{2}{|l|}{ 2. Review No. } \\
\hline & & & & \multicolumn{2}{|c|}{3 of 3} \\
\hline $\begin{array}{ll}12 . \\
\text { Item }\end{array}$ & $\begin{array}{l}\text { 13. Corment (s)/oiscrepancy(s) (Provide technical justification for the } \\
\text { comment and detai led recormendation of the action required to correct/ } \\
\text { resolve the discrepancy/problem indicated.) }\end{array}$ & $\begin{array}{l}14 . \\
\text { Hoid } \\
\text { Point }\end{array}$ & \multicolumn{2}{|c|}{ 15. Disposition (Provide justification if NOT accepted.) } & $\begin{array}{l}16 . \\
\text { status }\end{array}$ \\
\hline 10. & $\begin{array}{l}\text { Section } 6.4 .1 .4 .4 \text {, paragraph Industrial Safety - } \\
\text { Lexan is seif-extinguishing and not fire retardant. } \\
\text { It will still burn when exposed to a flame. }\end{array}$ & & \multicolumn{2}{|c|}{$\begin{array}{l}\text { Changed to reference to Lexan as self } \\
\text { extinguishing. }\end{array}$} & \\
\hline 11. & $\begin{array}{l}\text { Section } 6.4 .1 .4 .4 \text {, paragraph Industrial Safety - The } \\
\text { fire extinguishers now have bayonets which are an } \\
\text { improvement over the old wands. }\end{array}$ & & \multicolumn{2}{|c|}{$\begin{array}{l}\text { Changed text on fire extinguishers to } \\
\text { indicate that they have bayonets. }\end{array}$} & \\
\hline 12. & 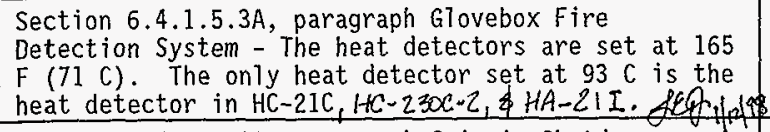 & & \multicolumn{2}{|l|}{ Changed text to $71 \mathrm{C}$. } & \\
\hline 13. & $\begin{array}{l}\text { Section } 6.4 .1 .5 .3 \mathrm{~A} \text {, paragraph Seismic Shutdown } \\
\text { Switch - The seismic shutdown switch also shuts down } \\
\text { the normal power to the Calciner Fire control panel } \\
\text { and forces it onto its battery backup. }\end{array}$ & & \multicolumn{2}{|c|}{ Added this statement to the text. } & \\
\hline & & & & \\
\hline & & & \multicolumn{2}{|l|}{2} & \\
\hline & & & & \\
\hline & & & & & \\
\hline
\end{tabular}




\section{REVIEW COMMENT RECORD (RCR)}

\begin{tabular}{|l|l|}
\hline $\begin{array}{l}\text { 1. } \text { Date } \\
\text { December 21, 1998 }\end{array}$ & \multicolumn{2}{|c|}{\begin{tabular}{c} 
2. Review No. \\
\hline $\begin{array}{c}\text { 3. Project No. } \\
\text { N/A }\end{array}$
\end{tabular}} & 4. Page 1 of 3 \\
\hline
\end{tabular}

5. Document Number(s)/Title(s)

Final Safety Analysis Report (FSAR) HNF-SD-CP-SAR-021. Rev. I
6. Program/Project/ Building Number

Plutonium

Finishing Plant (PFP)

\section{Reviewer}

DJ WIATRAK/FDH

KH JATEN/FDH

8. Organization/Group
OCCUPATIONAL SAFETY
\& HEALTH

9. Location/Phone

2355 Stevens $0 r$. 376 -8805/3739027

17. Comment Submittal Approval:

Organization Manager (Optional)
10. Agreement with indicated comment dispgzition(s) 0 i $/ 07 / 99$ Resfiewer/Point of Contact

\section{Date}

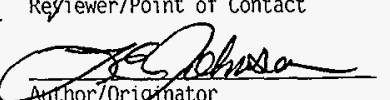

\section{CLOSED $01 / 07 / 99$}

Date

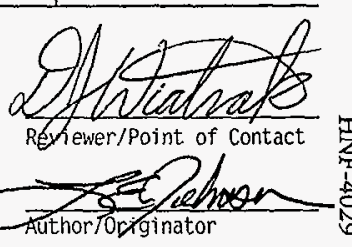

फ़

\begin{tabular}{|c|c|c|c|c|}
\hline $\begin{array}{l}12 . \\
\text { Ite } \\
\text { m }\end{array}$ & $\begin{array}{l}\text { 13. Comnent(s)/Discrepancy(s) (Provide technical justification } \\
\text { for the comment and detailed recommendation of the action required } \\
\text { to correct/ resolve the discrepancy/problem indicated.) }\end{array}$ & $\begin{array}{l}14 . \\
\text { Hold } \\
\text { Point }\end{array}$ & $\begin{array}{l}\text { 15. Disposition (Provide justification if NOT } \\
\text { accepted.) }\end{array}$ & $\begin{array}{l}16 . \\
\text { Statu } \\
\text { s }\end{array}$ \\
\hline 1. & $\begin{array}{l}\text { Chapter } 4 \text { - Section } 4.4 .8 \text {. Item } 3 \text {, states that } \\
\text { compressed gas system installations meet the } \\
\text { requirements of WHC-CM-4-40 and WHC-CM-1-10. These } \\
\text { two references are no longer applicable. A similar } \\
\text { update is a7so needed in the References Section } \\
\text { (Page R4-5). }\end{array}$ & & $\begin{array}{l}\text { Changed text to met requirements and added } \\
\text { that it meets requirements of HNF-PRO-087. }\end{array}$ & \\
\hline 2. & $\begin{array}{l}\text { Chapter } 4 \text { - The last sentence to Section } 4.4 .8 \text {, Item } \\
10 \text {, is missing an intended document reference. }\end{array}$ & & It is a typo "tab" which left extra spaces. & \\
\hline 3. & $\begin{array}{l}\text { Chapter } 4 \text { - Section } 4.4 .8 \text { fails to acknowiedge that } \\
\text { requirements are in place for design, operation, and } \\
\text { maintenance of overhead cranes and hoists. }\end{array}$ & & Accept, added sentence to item $\# 12$. & \\
\hline
\end{tabular}




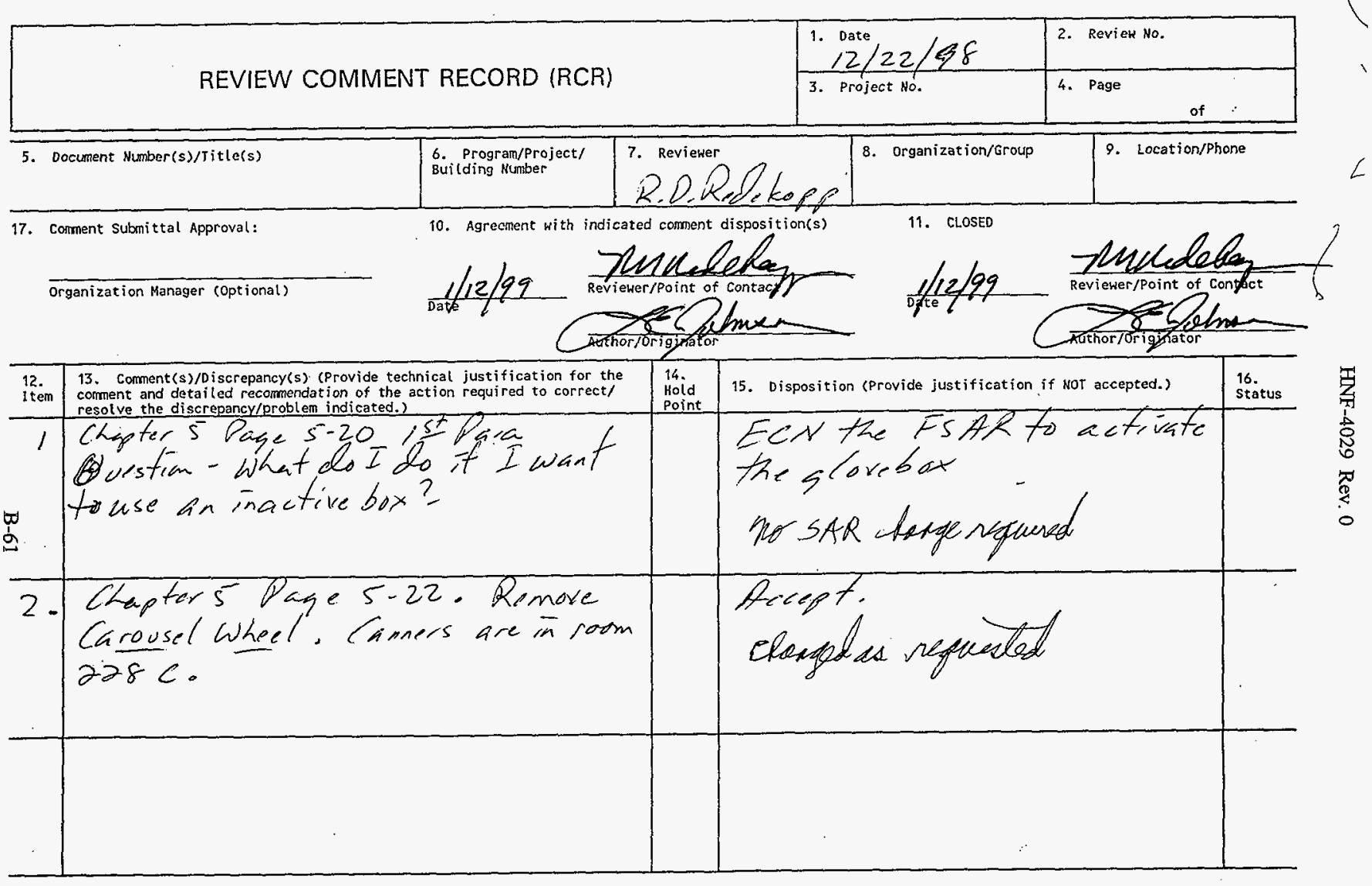

A-6400-090.1 (03/92) WEF011 


\section{REVIEW COMMENT RECORD (RCR)}

\begin{tabular}{|c|l|}
\hline 1. Date & 2. Review No. \\
$12 / 28 / 98$ & jpkch5 \\
\hline $\begin{array}{c}\text { 3. Project No. } \\
\text { PFP SAR }\end{array}$ & 4. Page 1 of 5 \\
\hline
\end{tabular}

\section{Document Number(s)/Title(s)}

WAC-SD-CP-SAR-021 Draft Rev, 1 Plutonium Finishing Plant Final Safety Analys is Report Chapter 5

17. Comnent Submittal Aoproval:

Organization Managex (Optional)

\begin{tabular}{|l|l|}
\hline $\begin{array}{l}\text { 6. Program/Project/ } \\
\text { Building Numbex } \\
\text { PFP Authorization } \\
\text { Basis }\end{array}$ & 7. Reviewer \\
\hline
\end{tabular}

8. Organization/Group
PFP Ops/15310

10. Agreement with indigated comment disposition(s) 10. Agrement

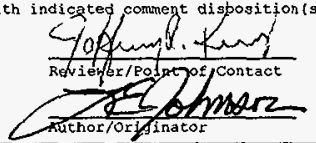

11. CLOSED

or the 13. Comment(s)/Discrepancy (s) (Provide technical fustification for the
comment and detailed recommendation of the action required to correct/ 12.
Item
cosolment and detailed recommendation of the

1 Page 5-iv, PREFACE, 4th Para., 4th Sentence; DELETE "operation and". While the function of the electrically driven ventilation back up fans remains unchanged, the operation is significantly different.

2 Page 5-2, 5.1.2.2, 3rd Sentence: DELETE "[an ICF Kaiser Hanford (ICFKH) facility containing part of the PFP plutonium inventaryl" and DELETE "(both are Bechtel facilities)"

3 Page $5-3,5.1,2.4 .1$, 2nd Bullet: DELETE reference to $65-\mathrm{kH}$ generator in 2736-ZR. It has been removed.

4 Page 5-4, 5.2, 4th Para., 7th Bullet: DELETE reference to 231-2 being an \begin{tabular}{l|l}
40 & 4 \\
\hline & ICFKH facility.
\end{tabular}

5 Page 5-5, 5.2, 5th Para.: DELETE entire existing ist sentence. DELETE existing sth Sentence (use as MICON test facility has no unique radiological or industrial hazards, sentence adds no value to the SAR). DELETE existing 7 th Sentence reference to $231-2$ being an ICFKH facility.

6 Page $5-13,5.2 .1 .2 .1$, 1st Bullet, INSERT HA-22B immediately after HA-28.

7 Page 5-14, 5.2.1.2.2, ist Para., 2nd Sentence: INSERT HA-22B immediately after $M A-28$.

8 Page 5-19, RMA Line Thermal Stabilization Gloveboxes: QUESTION: Where is discussion of HA-20NB? It is mentioned in 2nd Bullet very briefly, but there is no discussion on pages 5-19 or 5-20. It does not appear in Table 5-6 for inactive RMA gloveboxes, but it is shown as being used for cementation process in figure 5-10.

INSERT HA-22B immediately after HA-28. 2nd Bullet, INSERT new sentences between existing 2 nd and 3rd Sentences: "HA-22B is a small access glovebox at tached to HA-28 between HA-21I and HA-23S. HA-22B is used to seal items into the HA-28 conveyor."

9 Page 5-20, RMA Misc Gloveboxes, 4th Sentence: CHANGE "Wet" to "formerly wet process". DELETE HA-22

\begin{tabular}{|c|c|c|}
\hline & & \\
\hline \multirow[t]{2}{*}{$\begin{array}{l}14 . \\
\text { Hold } \\
\text { Point }\end{array}$} & 15. Disposition (Erovide justification if Nor accepted.) & $\begin{array}{l}16 . \\
\text { Status }\end{array}$ \\
\hline & Changed as stated. & \\
\hline & Changed as stated. & \\
\hline & Changed as stated. & \\
\hline & Changed to "under cognizanze of another BuHC organization. & \\
\hline & $\begin{array}{l}\text { Modified 1st sentence but need some mention of } 2-9 \text { retained. } \\
\text { Deleted 6th sentence. } \\
\text { Deleted reference to ICFKH facility and said "separate BWHC } \\
\text { organization." }\end{array}$ & \\
\hline & Changed as stated. & \\
\hline & Inserted $\mathrm{HA}_{\mathrm{A}-2 \mathrm{Z}}$. & \\
\hline & $\begin{array}{l}\text { HA-20MB is not a "stabilization" glovebox. 2nd bullet is just } \\
\text { talking about what HA-28 serves which includes HA-2OHB. HA-20 } \\
\text { MB is in seismic event release but is not considered for } \\
\text { cementation operations. Theoretically, it can have } 10,000 \mathrm{~g} \\
\text { inventory but no operations. Added HA-22B as a new bultet and } \\
\text { added HA-22B in locations as requested. }\end{array}$ & \\
\hline & Changed as stated. & \\
\hline
\end{tabular}




\begin{tabular}{|c|c|}
\hline $\begin{array}{l}\text { 1. Date } \\
12 / 28 / 98\end{array}$ & 2. Review No. \\
\hline $\begin{array}{c}\text { 3. Eroject No. } \\
\text { PFP SAR }\end{array}$ & 4. Page $\quad 2$ of 5 \\
\hline
\end{tabular}

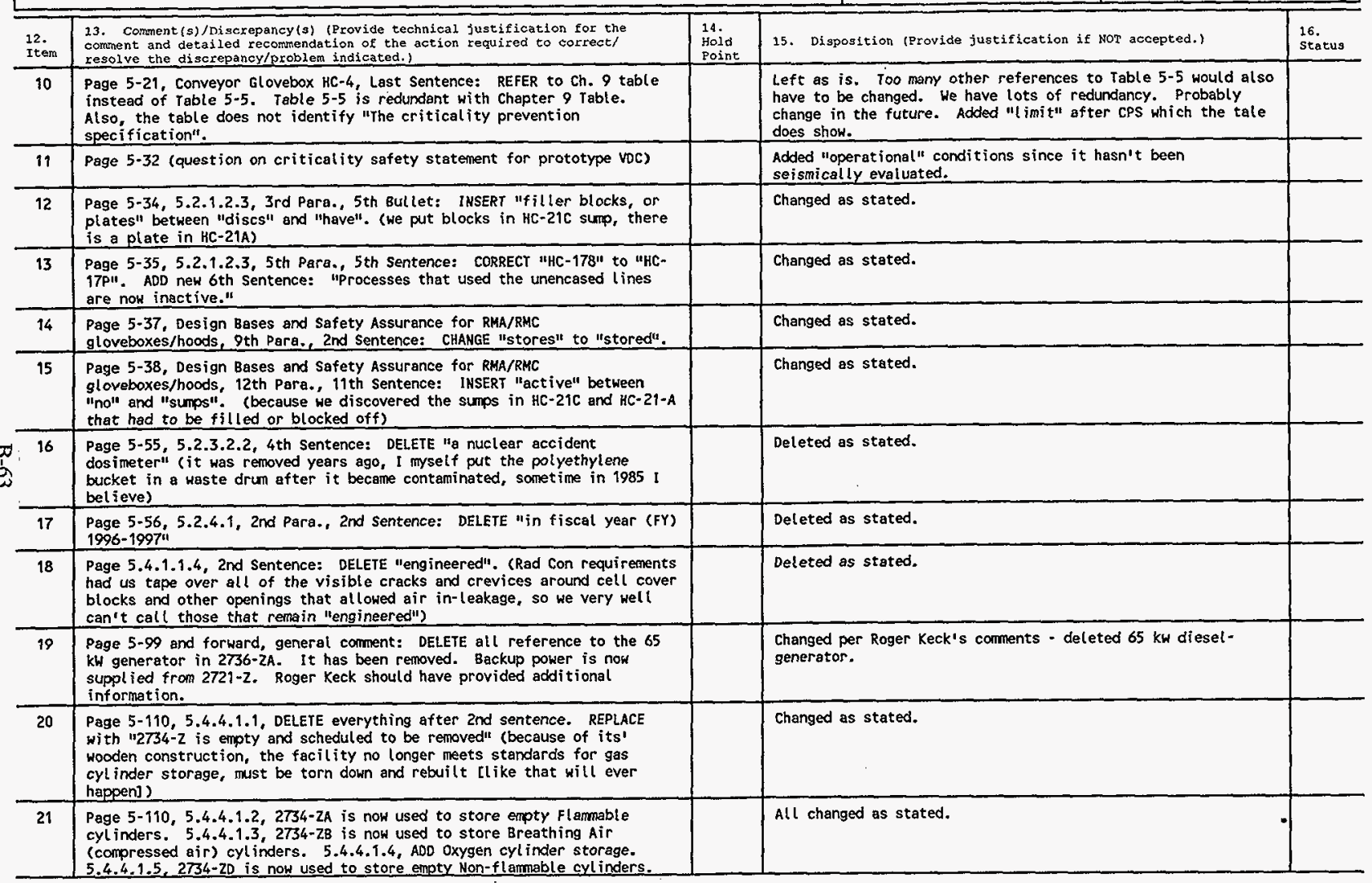




\begin{tabular}{|c|c|c|c|c|c|}
\hline \multirow{2}{*}{\multicolumn{3}{|c|}{ REVIEW COMMENT RECORD (RCR) }} & $\begin{array}{l}\text { 1. Date } \\
12 / 28 / 98 \\
\end{array}$ & \multicolumn{2}{|l|}{$\begin{array}{r}\text { 2. Review No. } \\
\text { jpkch5 }\end{array}$} \\
\hline & & & $\begin{array}{l}\text { 3. Project No. } \\
\text { PFP SAR }\end{array}$ & 4. Page & \\
\hline $\begin{array}{l}\text { 12. } \\
\text { Itern }\end{array}$ & $\begin{array}{l}\text { 13. Comment (s)/Discrepancy (s) (Provide technical justification for the } \\
\text { comment and detailed recommendation of the action reguired to correct/ } \\
\text { resolve the discrepancy/problem indicated.) }\end{array}$ & $\begin{array}{l}\text { 14. } \\
\text { Hold } \\
\text { Point }\end{array}$ & \multicolumn{2}{|c|}{ 15. Disposition (Provide justification if NoT accepted.) } & $\begin{array}{l}16 . \\
\text { Status }\end{array}$ \\
\hline 22 & $\begin{array}{l}\text { Page 5-111, 5.4.4.1.6, } 2734-2 \mathrm{~F} \text { is now used to store Argon cylinders. } \\
5.4 .4 .1 .8,2734-2 \mathrm{H} \text { is out of service. } 5.4 .4 .1 .10 . \text {, DELETE "Oxygen" from } \\
\text { title. ADD "Propane, Acetylene, Hel ium, and other miscellaneous } \\
\text { flamable gases" to title. DELETE existing } 4 \text { th sentence (storage is not } \\
\text { temporary). Existing } 5 \text { th sentence, CHANGE to "Ventilation occurs by } \\
\text { natural air movement through the expanded metal grating doors and through } \\
\text { nitrogen, argon, acetylene, and propane are stored in a concrete, } \\
\text { nitransite, and steel enclosure at the } 234-2 B \text { building for use by } \\
\text { construction forces." }\end{array}$ & & \multicolumn{2}{|l|}{ All changed as stated. } & \\
\hline 23 & $\begin{array}{l}\text { Page 5-120, 5.4.9.1, 2nd Sentence: DELETE reference to } 2607-z \text { tile drain } \\
\text { field. REPLACE with "pump stations, and to the } 2607-41 \text { regional } \\
\text { drainfield located to the east approximately one half mile away." 2nd } \\
\text { Paragraph: Same changes as above. Just sum it up as all drain field } \\
\text { effluent gets pumped up to } 2607-\mathrm{W} 1 \text {. DELETE last sentence concerning } \\
\text { frequent pumping of tanks. The H1 upgrade project fixes this. }\end{array}$ & & \multicolumn{2}{|l|}{ Reworded sections. } & \\
\hline 24 & $\begin{array}{l}\text { Page } 5-125,5.4 .10 .1 .6 \text {, 2nd Para., } 7 \text { th Sentence: REPLACE with "Upon } \\
\text { actuation of the alarm, facility workers are trained to promptly evacuate } \\
\text { the affected air spBCe," DELETE "while holding their breath" }\end{array}$ & & \multicolumn{2}{|l|}{ Changed as stated. } & \\
\hline 25 & $\begin{array}{l}\text { Page } 5-127,5.4 .10 .2 .1,3 \mathrm{rd} \text { Para.: IMSERT new sentence immediately } \\
\text { before existing } 3 \mathrm{rd} \text { Sentence; "Panel } \mathrm{z}-8 \text { only actuates howlers in the } \\
\text { immediate area of } 241-2.1\end{array}$ & & \multicolumn{2}{|l|}{ Added sentence. } & \\
\hline 26 & Page 5-128, 5.4.10.2.2, 2nd Para., DELETE reference to 2736 -2A generator. & & \multicolumn{2}{|l|}{ Deleted offending statement. } & \\
\hline 27 & $\begin{array}{l}\text { Page } 5-129,5.4 .11 .1 .1,4 \text { th Para., 2nd Sentence: CHANGE to "The quantity } \\
\text { of LPG is administratively restricted to } 465 \mathrm{~g}(16.4 \text { O2) per cylinder, } \\
\text { with no more than } 2 \text { cylinders allowed in any single room, and no more } \\
\text { than } 6 \text { allowed in a building containing an inventory of transuranic } \\
\text { materials." }\end{array}$ & & \multicolumn{2}{|l|}{ Changed as stated. } & \\
\hline 28 & $\begin{array}{l}\text { Page } 5-130,5.4 .11 .1 .1,8 \text { th Para., 2nd Sentence: CHANGE "sealed" to } \\
\text { "conf ined". (can't very well have something sealed and vented at the same } \\
\text { time) }\end{array}$ & & \multicolumn{2}{|l|}{ Changed as stated. } & \\
\hline 29 & $\begin{array}{l}\text { Page 5-131, The } 236-2 \text { Buitding, ist Sentence: INSERT "inactive" between } \\
\text { "the" and "PRF". }\end{array}$ & & \multicolumn{2}{|l|}{ Changed as stated. } & \\
\hline 30 & $\begin{array}{l}\text { Page } 5-141,5.4 .11 .5,2 \text { nd Para., 1st Sentence: DELETE "plant". (These } \\
\text { guys don't work for us, they are a separate site maintenance group.) }\end{array}$ & & \multicolumn{2}{|l|}{ Chenged as stated. } & \\
\hline 31 & $\begin{array}{l}\text { Page } 5-145,5.4 .13 .2 \text { and subsections: OELETE everything after "(Figure } \\
5-64) \text { ". REPLACE with; } \\
\text { "All PRF processes are currently inactive and not authorized for } \\
\text { operation. Chemicals renaining in the PRF tanks and process lines will } \\
\text { be managed and dispositioned in accorclance with HNF-2977, "p lutonium } \\
\text { Reclamation Facility (PRF, Bui (ding } 236-2 \text { ) Layp Plen" BWHE, 1998. } \\
\text { Electrical to instrumentation in the room has been isolated." }\end{array}$ & & \multicolumn{2}{|c|}{$\begin{array}{l}\text { Added requested sentence; deleted most material as requested } \\
\text { but left a list of tanks and former contents. }\end{array}$} & \\
\hline
\end{tabular}




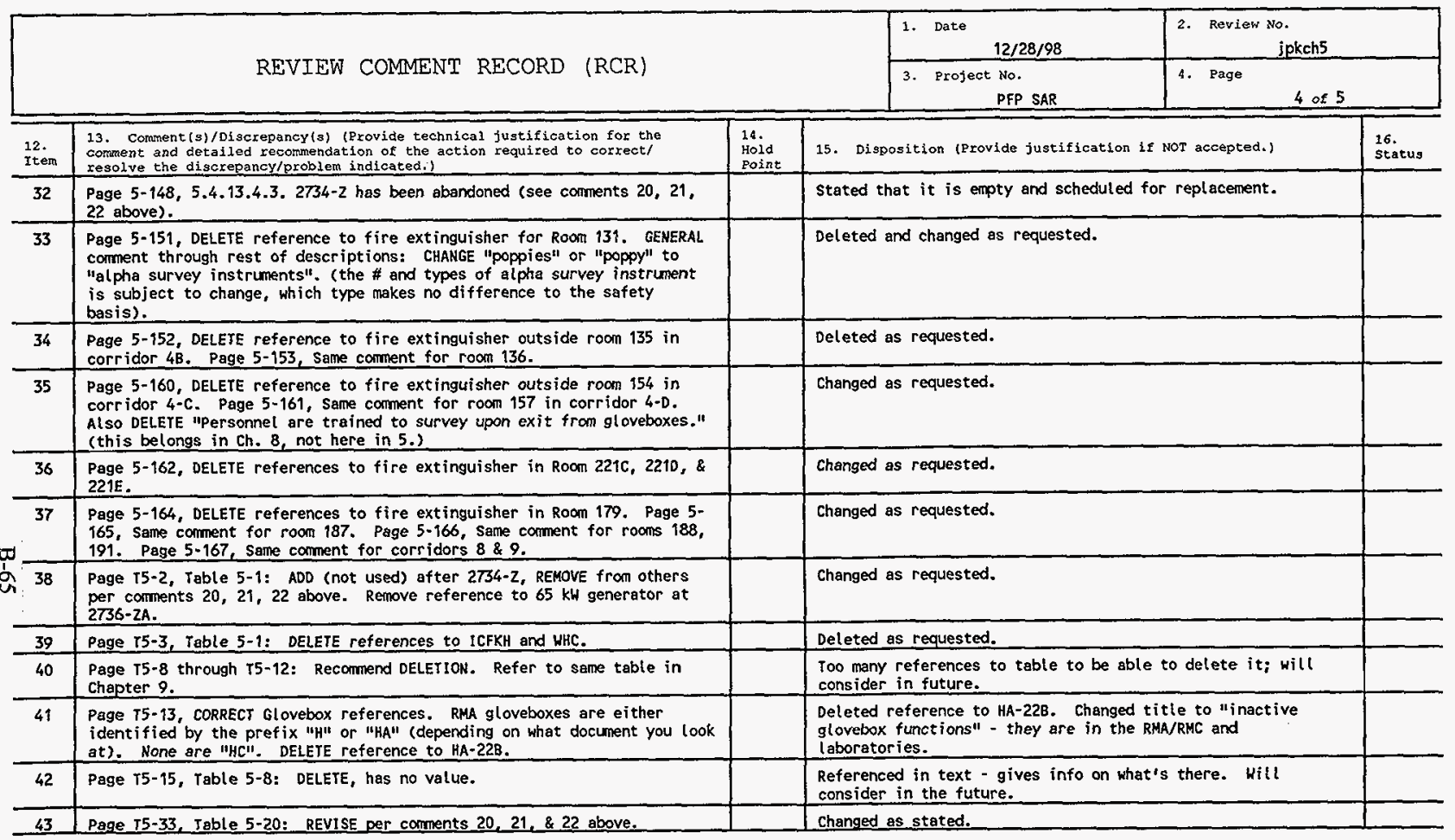




\begin{tabular}{|l|l|l|l|}
\hline \multirow{2}{*}{ REVIEW COMMENT RECORD (RCR) } & 1. Date & 2. Review No. \\
\cline { 2 - 4 } & 3. Project No. & PFkch5 \\
PFP SAR & 4. Page \\
\hline
\end{tabular}

\begin{tabular}{|c|c|c|c|c|}
\hline $\begin{array}{l}12 . \\
\text { rtem }\end{array}$ & $\begin{array}{l}\text { 13. Comment(s)/Discrepancy(s) (Erovide technical justification for the } \\
\text { comment and dotailed recommendation of the action required to correct/ } \\
\text { resolve the discrepancy/problen indicated.) }\end{array}$ & $\begin{array}{l}\text { 14. } \\
\text { Hola } \\
\text { Point }\end{array}$ & 15. Disposition (Provide justification if NOT accepted.) & $\begin{array}{l}\text { 16. } \\
\text { status }\end{array}$ \\
\hline 44 & 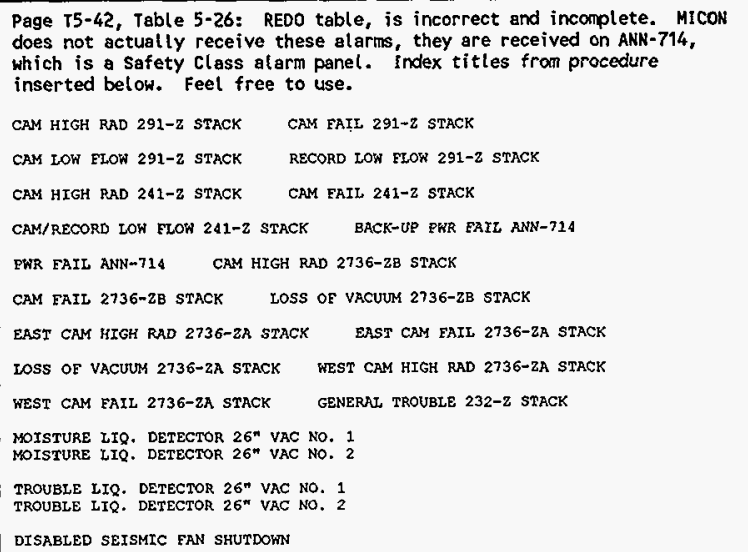 & & Changed table to itens listed in comment. & \\
\hline 45 & Page F5-28, through F5-36, Figure 5-16: DELETE adds no value & & $\begin{array}{l}\text { Retained; let's people know what's there and too difficult to } \\
\text { remove references to figure. }\end{array}$ & \\
\hline 46 & Page $75-42$, Figure 5-22: DELEIE & & Retained; same as above. & \\
\hline 47 & Page F5-43, \& F5-44, Figure 5-23: DELETE & & Retained; same as above. & \\
\hline 48 & Page F5-45, Figure 5-24: DELETE & & Retained; same as above. & \\
\hline 49 & $\begin{array}{l}\text { Page } 55-78, \text { Figure 5-54: UPDATE per corments } 20,21,22 \text { above. } 27352 \\
\text { square chemical cabinet is in wrong spot. Is actualiy between nitric } \\
\text { tank (close to it) and } 2734-Z \text { (also misidentified). }\end{array}$ & & Added rate to figure regarding required changes. & \\
\hline 50 & $\begin{array}{l}\text { Page } 55-84, \text { Figure } 5-60: \text { UPDATE to show new sewer line configuration per } \\
\text { project } L-281 \text { work. Hill bring updated construction drawing down to you. }\end{array}$ & & Used new figure. & \\
\hline
\end{tabular}




\begin{tabular}{|l|l|l|l|}
\hline \multirow{2}{*}{ REVIEW COMMENT RECORD (RCR) } & 1. Date $12 / 21 / 98$ & 2. Review No. \\
\cline { 2 - 4 } & 3. Project No. & 4. Page 1 of 3 \\
\hline
\end{tabular}

\begin{tabular}{|c|c|c|c|c|c|c|c|}
\hline \multicolumn{2}{|c|}{$\begin{array}{l}\text { 5. Document Number(s)/Title(s) } \\
\text { HNF-SD-CP-SAR-021, Chapters } 5,6 \& 9\end{array}$} & $\begin{array}{l}\text { 6. Program/project/ } \\
\text { Building Number } \\
\text { PFP SAR }\end{array}$ & \multicolumn{2}{|c|}{$\begin{array}{l}\text { 7. Reviewer } \\
\text { R. D. Pickett }\end{array}$} & $\begin{array}{l}\text { 8. Organization/Group } \\
\text { PFP Facility Systems } \\
\text { Engineer }\end{array}$ & \multicolumn{2}{|c|}{$\begin{array}{l}\text { 9. Location/Phone } \\
\text { M0 } 016 / 372-1072\end{array}$} \\
\hline \multicolumn{2}{|c|}{ 17. Corment Submittal Approval: } & \multicolumn{4}{|c|}{ 10. Agreement with indicated comnent dispositignns) } & \multicolumn{2}{|c|}{ 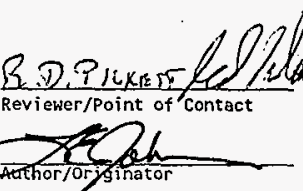 } \\
\hline $\begin{array}{l}12 . \\
\text { item }\end{array}$ & $\begin{array}{l}\text { 13. Comment(s)/Discrepancy(s) (Provide tech } \\
\text { corment and detail led recormendation of the } \\
\text { resolve the discrepancy/problem indicated.) }\end{array}$ & $\begin{array}{l}\text { ical justification for the } \\
\text { otion required to correct/ }\end{array}$ & $\begin{array}{l}14 . \\
\text { Hoid } \\
\text { Point }\end{array}$ & 15. Di & ovide justification if NOT & epted.) & $\begin{array}{l}16 . \\
\text { status }\end{array}$ \\
\hline 1. & $\begin{array}{l}\text { Section } 5.4 .11 .3 .8-\text { The MPFL } \$ \\
\$ 2,227,000 \text { instead of } \$ 2,270,00 \\
\end{array}$ & amount should be & & Accep & it revised as recommen & & \\
\hline 2. & $\begin{array}{l}\text { Section } 5.4 .11 .2 .3 \text { - The backup } \\
\text { protection system is batteries } \\
\text { control panels do also get power } \\
\text { supported by the diesels, but no } \\
\text { rule. }\end{array}$ & $\begin{array}{l}\text { power to the fire } \\
\text { orma } 71 y \text {. Some fire } \\
\text { from panels } \\
\text { t as a hard and }\end{array}$ & & Accep & t revised appropriate & & \\
\hline 3. & $\begin{array}{l}\text { Sections } 5.4 .11 .2 .6 \text { and } 9.2 .2 \mathrm{~A} .1 \\
\text { concentration according to the } \\
\text { instead of } 6 \% \text {. }\end{array}$ & $\begin{array}{l}\text { - The Halon } \\
\text { al on ATP is } 5 \%\end{array}$ & & Accep & t revised as recommen & & \\
\hline 4. & $\begin{array}{l}\text { Section } 9.2 .2 A .2 \text { - The probabi\} } \\
\text { agree between the paragraph C-1 } \\
\text { paragraph in the section. }\end{array}$ & $\begin{array}{l}\text { ty for } C-1 \text { does not } \\
\text { and the first }\end{array}$ & & The $c$ & The for $C-I$ is $2.5 \mathrm{E}$ & & \\
\hline
\end{tabular}




\section{REVIEW COMMENT RECORD (RCR)}

\begin{tabular}{|c|c|}
\hline $\begin{array}{l}\text { 1. Date } \\
1 / 6 / 99\end{array}$ & $\begin{array}{l}\text { 2. Review No. } \\
6-2\end{array}$ \\
\hline $\begin{array}{c}\text { 3. Project No. } \\
\text { PFP FSAR }\end{array}$ & 4. Page \\
\hline
\end{tabular}

\begin{tabular}{l|l|l|l|l}
\hline 5. Document Number(s)/Title(s) & $\begin{array}{l}\text { 6. Program/Project/ } \\
\text { Building Number } \\
\text { PFP FSAR }\end{array}$ & $\begin{array}{l}\text { 7. Reviewer } \\
\text { DR Groth }\end{array}$ & PFP-QA Organization/Group & 9. Location/Phone \\
\hline
\end{tabular}

17. Comment Submittal Approval:

Organization Manager (Optional)

$\underset{1}{\infty}$

So $12 . \quad$ 13. Comment(s)/Discrepancy(s) (Provide technical justification

Ite for the comment and detailed recommendation of the action required

m to correct// resolve the discrepancy/problem indicated.)

Comments taken from cc:mail, DR Groth to Ramble and

Johnson, date 12/21/98, "Comments on Chapter 6"

1. 6.1: PFP started operations on July 5, 1949, not 1950.

2. 6.4.1.1.1, second para ("Process Feed"). first sentence...

--Typo"...10 g of organic per change...", "change to "charge"

- - The sentence "... to meet long term storage requirements." needs to be before the colon in the middle of that sentence. It isn't essential to the sentence, so could be deleted if you wish.
11. CLOSED
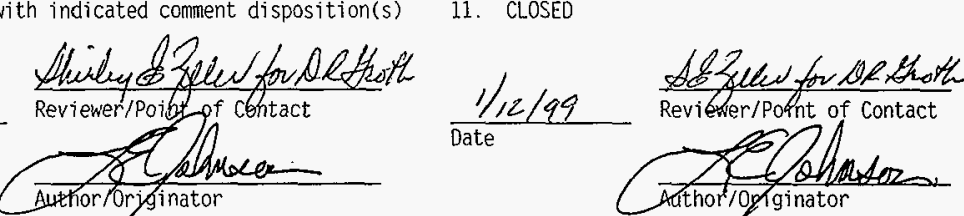

\begin{tabular}{|l|l|l}
\hline $\begin{array}{l}\text { Hold } \\
\text { Point }\end{array}$ & $\begin{array}{l}\text { 15. Disposition (Provide justification if NOT } \\
\text { accepted.) }\end{array}$ & $\begin{array}{l}16 . \\
\text { Statu } \\
\text { s. }\end{array}$ \\
\hline & $\begin{array}{l}\text { Text changed as requested } \\
\text { Text changed as requested }\end{array}$ & \\
& $\begin{array}{l}\text { Text moved as suggested } \\
\end{array}$ &
\end{tabular}




\begin{tabular}{|l|l|l|l|}
\hline \multirow{2}{*}{ REVIEW COMMENT RECORD (RCR) } & $\begin{array}{l}\text { 1. Date } \\
1 / 6 / 99\end{array}$ & $\begin{array}{c}\text { Review No. } \\
6-2\end{array}$ \\
\cline { 2 - 4 } & $\begin{array}{l}3 . \text { Project No. } \\
\text { PFP FSAR }\end{array}$ & 4. Page \\
\hline
\end{tabular}

\begin{tabular}{|c|c|c|c|c|}
\hline $\begin{array}{l}12 . \\
\text { Ite } \\
\text { m. }\end{array}$ & $\begin{array}{l}\text { 13. Comment(s)/Discrepancy(s) (Provide technical justification } \\
\text { for the corment and detailed recommendation of the action required } \\
\text { to correct/ resolve the discrepancy/problem indicated.) }\end{array}$ & $\begin{array}{l}14 . \\
\text { Hoid } \\
\text { Point }\end{array}$ & $\begin{array}{l}\text { 15. Disposition (Provide justification if NOT } \\
\text { accepted.) }\end{array}$ & \begin{tabular}{|l}
16. \\
Statu \\
s
\end{tabular} \\
\hline 3. & $\begin{array}{l}\text { 6.4.1.1.1. third para... } \\
\text {-- In the 14th line } 2500 \mathrm{~g} \text { Pu content is cited as } \\
\text { the maximum charge size "... for criticality } \\
\text { control." The charge sizes in 0SD-2-184-00006, } \\
6.2 .4 \text { are considerably less and a function of } \\
\text { organic content. I'm aweare that } 2500 \mathrm{~g} \mathrm{Pu} \text { is what } \\
\text { is wanted in the future, but for now I recommend } \\
\text { that the sentence be revised to read "Unless } \\
\text { otherwise administratively limited, the maximum } \\
\text { charge size will be } 2500 \mathrm{~g} \text { Pu for criticality } \\
\text { control purposes." } \\
\\
\text { offgas does not match current procedure. I } \\
\text { discussed this with Rees, and will leave suggestions } \\
\text { for editing of the offgas sentences to him. }\end{array}$ & & $\begin{array}{l}\text { No change required. A maximum charge size } \\
\text { of } 2500 \mathrm{~g} \text { Pu is used in the accident } \\
\text { analysis and is therefore the estab7ished } \\
\text { FSAR analyzed limit. This does not preclude } \\
\text { other lower limits, such as an } \\
\text { administrative limit in an OSD. However. we } \\
\text { need to avoid identifying these other limits } \\
\text { in the FSAR. If and when the plant wants to } \\
\text { change an administrative limit, to any value } \\
\text { less than } 2500 \text {, they can easily do it } \\
\text { without having to go through the difficult } \\
\text { process of an FSAR change. } \\
\text { Rewritten per Rees Risenmay comments. }\end{array}$ & \\
\hline 4. & $\begin{array}{l}\text { Page } 6-29 \text {. Feed Rate Limits. The first sentence is } \\
\text { worded such that } 0.5 \% \text { is a target. Recommend that } \\
\text { the wording be revised to "... is sufficient to } \\
\text { reduce the weight percent LoI to } 0.55 \text { or less." }\end{array}$ & & Text changed as recommended. & \\
\hline 5. & No comment \# 5 & & & \\
\hline
\end{tabular}




\section{REVIEW COMMENT RECORD (RCR)}

\begin{tabular}{|c|c|}
\hline $\begin{array}{c}\text { 1. Date } \\
1 / 6 / 99\end{array}$ & $\begin{array}{c}\text { 2. Review No. } \\
6-2\end{array}$ \\
\hline $\begin{array}{c}\text { 3. Project No. } \\
\text { PFP FSAR }\end{array}$ & 4. Page \\
3 of 4 \\
\hline
\end{tabular}

\begin{tabular}{|c|c|c|c|c|}
\hline $\begin{array}{l}12 . \\
\text { Ite } \\
m\end{array}$ & $\begin{array}{l}\text { 13. Comment(s)/Discrepancy(s) (Provide technical justification } \\
\text { for the comment and detailed recommendation of the action required } \\
\text { to correct/ resolve the discrepancy/problem indicated.) }\end{array}$ & $\begin{array}{l}14 \\
\text { Hold } \\
\text { Point }\end{array}$ & $\begin{array}{l}\text { 15. Disposition (Provide justification if NOT } \\
\text { accepted.) }\end{array}$ & $\begin{array}{l}16 . \\
\text { Statu } \\
\mathrm{s} \\
\end{array}$ \\
\hline 6. & $\begin{array}{l}\text { Page } 6-31 \text {, first sentence of } 6.4 .1 .2 \text { is similar to } \\
\text { the one described in comment } 2 \text {, above. Recommend } \\
\text { relocating or deleting "...to meet long term storage } \\
\text { requirements". }\end{array}$ & & Text changed as per $\# 2$ above. & \\
\hline 7. & $\begin{array}{l}\text { Page 6-36, para starting "Glovebox HC-21A". } \\
\text { Recommend deleting "A supply of containers, known as } \\
\text { "boats" is kept in the glovebox." I don't know how } \\
\text { many containers are allowed in } \mathrm{HC}-21 \mathrm{~A} \text {. but it can't } \\
\text { be many. The sentence is not needed and could be a } \\
\text { problem. }\end{array}$ & & The text is deleted as requested. & \\
\hline 8. & $\begin{array}{l}\text { Page } 6-36,4 \text { th line, Typo: "26-in. }-\mathrm{Hg}^{\prime} \text { should be } \\
\text { "26-in. Hg". }\end{array}$ & & Tech editing perfers the "- $\mathrm{Hg} "$. & \\
\hline 9. & $\begin{array}{l}\text { Page 6-47. Para } 6.4 .1 .7 \text { and elsewhere. There is } \\
\text { much discussion regarding LOI. I know it isn't in } \\
\text { the storage specification. but a gain on ignition is } \\
\text { taken as (sic) an indication that the oxidation } \\
\text { reactions may not have gone to completion and may be } \\
\text { masking some degree of LOI as well. Do we have any } \\
\text { constraints on GOI? }\end{array}$ & & $\begin{array}{l}\text { The text is changed to reference the storage } \\
\text { specification. }\end{array}$ & \\
\hline 10. & $\begin{array}{l}\text { Page } 6-49,6.4 .1 .9 .2 \text {, bottom of } 2 \text { nd para: There is } \\
\text { the inference that offgas is also stopped when } \\
\text { covergas is stepped. Need to revise per Rees. } \\
\text { recommendation. }\end{array}$ & & $\begin{array}{l}\text { Text changed per Rees Risenamay comment on } \\
\text { page } 6-26 \text {. }\end{array}$ & \\
\hline 11. & $\begin{array}{l}\text { Page } 6 / 91,6.6 .1 .3 .3, \text { last sentence. Did we dispose } \\
\text { of those chemicals by } 12 / 31 / 97 \text {, as stated? }\end{array}$ & & $\begin{array}{l}\text { Text revised to reference chemical hazard. } \\
\text { assessment. }\end{array}$ & \\
\hline
\end{tabular}




\begin{tabular}{|c|l|l|l|}
\hline REVIEW COMMENT RECORD (RCR) & $\begin{array}{l}\text { 1. Date Review No. } \\
\cdot 6-2\end{array}$ \\
\cline { 2 - 4 } & $\begin{array}{c}\text { 3. Project No. } \\
\text { PFP FSAR }\end{array}$ \\
\hline
\end{tabular}

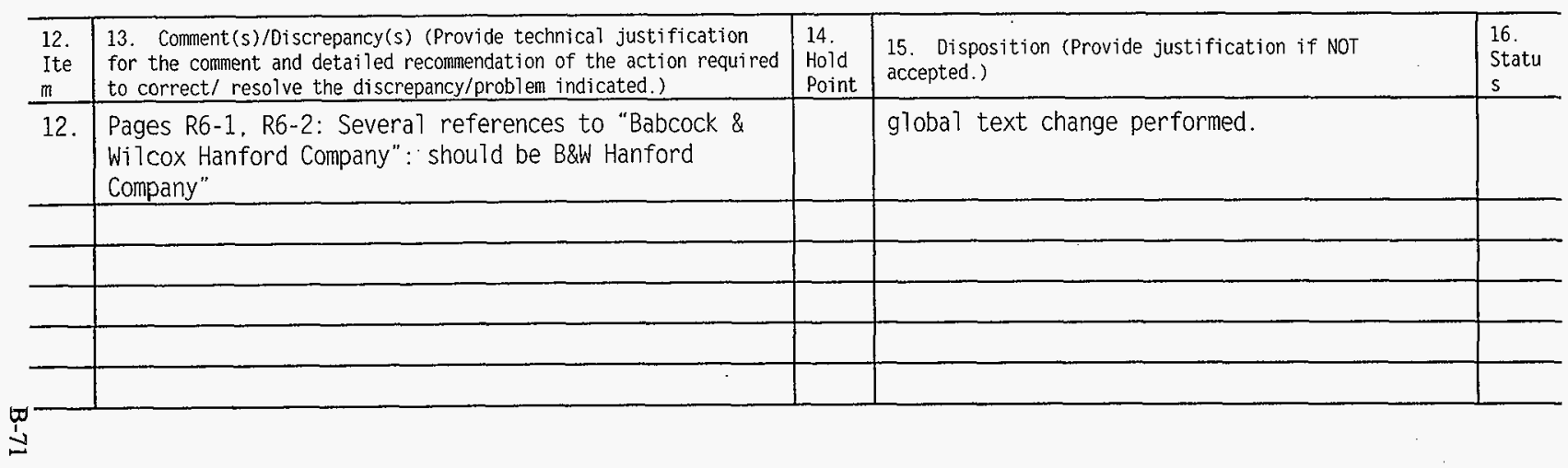




\begin{tabular}{|l|l|l|l|}
\hline REVIEW COMMENT RECORD (RCR) & $\begin{array}{l}\text { 1. Date } \\
1 / 6 / 99\end{array}$ & Review No. \\
\cline { 2 - 4 } & $\begin{array}{c}\text { 3. Project No. } \\
\text { PFP FSAR }\end{array}$ & $\begin{array}{l}\text { 4. Page } \\
1 \text { of } 2\end{array}$ \\
\hline
\end{tabular}

\begin{tabular}{|c|c|c|c|c|c|c|c|c|}
\hline \multicolumn{2}{|c|}{$\begin{array}{l}\text { 5. Document Number(s)/Tit7e(s) } \\
\text { HNF-SD-CP-SAR-021, Chapter } 6\end{array}$} & $\begin{array}{l}\text { 6. Program/Project/ } \\
\text { Building Number } \\
\text { PFP FSAR }\end{array}$ & & Reviewe & & $\begin{array}{l}\text { 8. Organization/Group } \\
\text { PFP Analytical Labs }\end{array}$ & \multicolumn{2}{|c|}{ 9. Location/Phone } \\
\hline \multirow[t]{2}{*}{17.} & Comment Submittal Approval: & \multirow{2}{*}{\multicolumn{5}{|c|}{$\begin{array}{l}\text { 10. Agreement with indicated comment disposition(s) 11. CLOSEO } \\
\text { 1/11/q9 pé attaded ceimail }\end{array}$}} & & \\
\hline & Organization Manager (Optional) & & & & & & & \\
\hline \multirow[t]{2}{*}{$\begin{array}{l}\text { Nite } \\
\text { Ite } \\
\text { m }\end{array}$} & $\begin{array}{l}\text { 13. Comment (s)/Discrepancy }(\mathrm{s})(\mathrm{Prc} \\
\text { for the corment and detailed recomn } \\
\text { to correct/ resolve the discrepancy }\end{array}$ & $\begin{array}{l}\text { technical justificatio } \\
\text { ion of the action requ } \\
\text { lem indicated.) }\end{array}$ & & $\begin{array}{l}14 . \\
\text { Hold } \\
\text { Point }\end{array}$ & $\begin{array}{l}\text { 15. Disp } \\
\text { accepted. }\end{array}$ & n (Provide justification & & $\begin{array}{l}6 \\
\text { Statu } \\
\text { s } \\
\end{array}$ \\
\hline & $\begin{array}{l}\text { Comment transferrred from co } \\
\text { Shapley, } 1 / 6 / 99 \text {, subject "SA }\end{array}$ & 1. Curfman to $\mathrm{J}$ & & & & & & \\
\hline
\end{tabular}




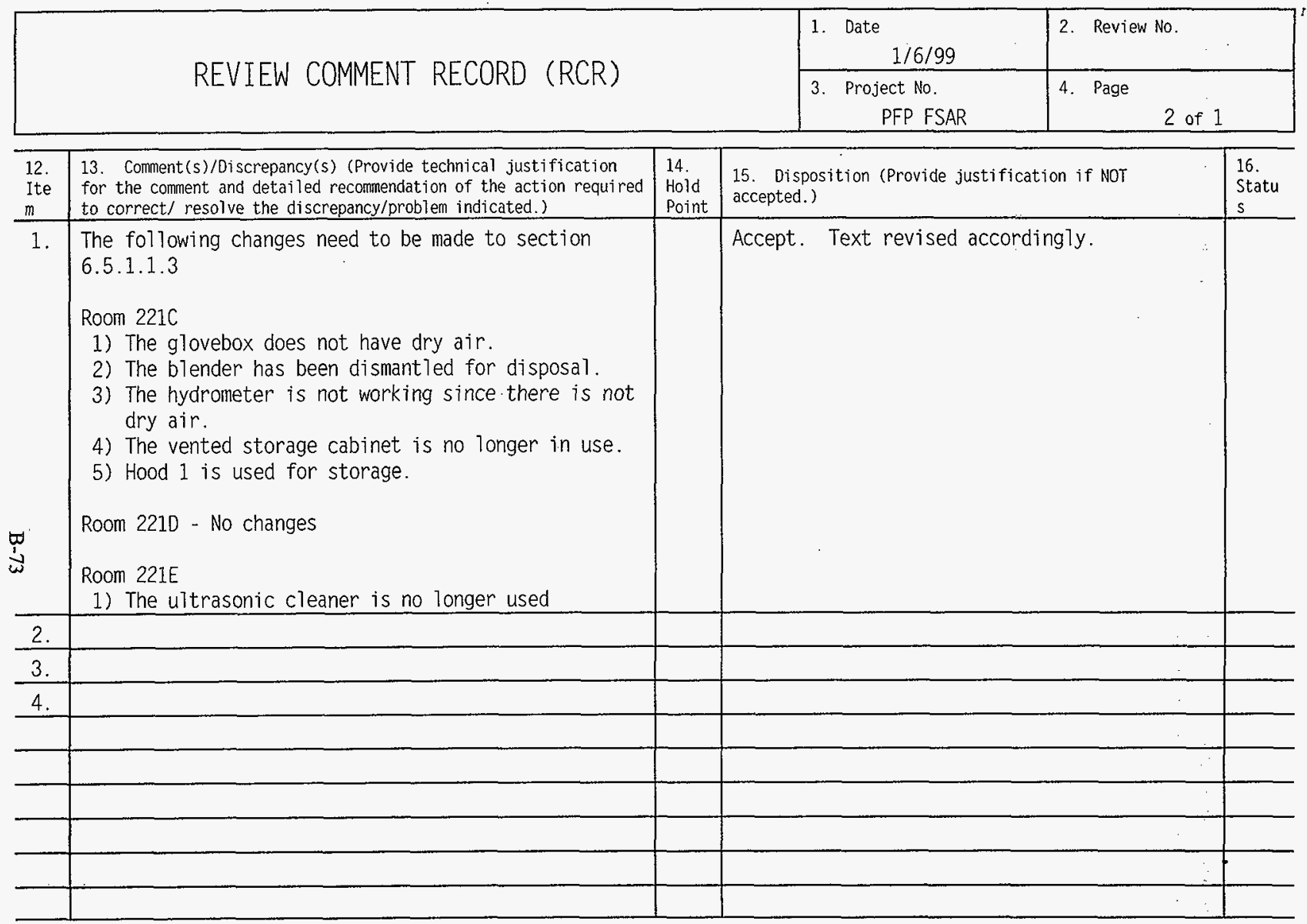




\section{Johnson, LE (Safety Analysis)}

From:

Sent:

To:

Subject:
Curfman, EW(Liz)

Monday, January 11, 1999 7:11 AM

Johnson, LE (Safety Analysis)

RE: PFP' FSAR Comment Dispositions

Larry, the disposition of my comments on Chapter 6 are acceptable. Please close the RCR.

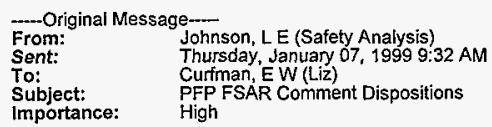

Liz,

Please find attached a RCR prepared from the cc:mail sent to J Shapley regarding Ch. 6 required revisions. Thanks, your information was helpful in updating the chapter. Would you please review the RCR and let me know if this looks acceptable? If so, a cc:mail from you (stating that the disposition is acceptable and that you consider the RCR closed) should suffice.

Thanks,

Larry Johnson

$376-8807$

« File: EWC6DISP.RCR 》 


\section{REVIEW COMMENT RECORD (RCR)}

\begin{tabular}{|c|c|}
\hline $\begin{array}{c}\text { 1. Date } \\
1 / 6 / 99\end{array}$ & $\begin{array}{l}\text { 2. Review No. } \\
6-1\end{array}$ \\
\hline $\begin{array}{c}\text { 3. Project No. } \\
\text { PFP FSAR }\end{array}$ & 4. Page \\
\end{tabular}

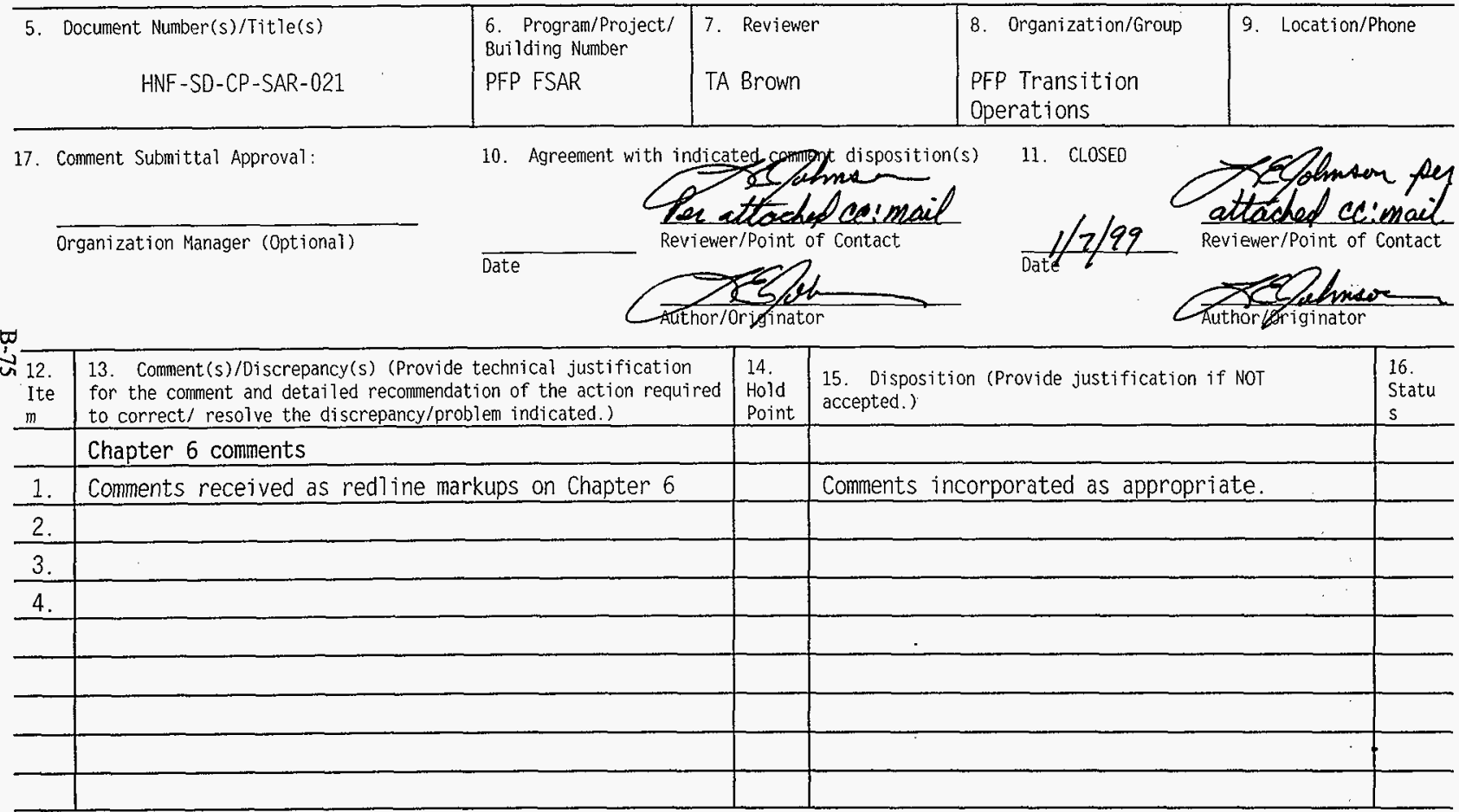


From:

Sent:

To:

Subject:
Brown, Thomas A

Wednesday, January 06, 1999 4:02 PM

Johnson, LE (Safety Analysis)

RE: PFP FSAR Chapter 6 Comments

-.--Original Message -.--..

From: Johnson, L E (Safety Analysis)

Sent: Wednesday, January 06, 1999 10:43 AM

To: Brown, Thomas A

Subject: PFP FSAR Chapter 6 Comments

Importance: High

I consider this item closed.

T.A. Brown

Tom,

You submitted redline markup comments on Chapter 6. Jim Shapley has incorporated them as appropriate. I've filled out a RCR form indicating this, see attached. If this is acceptable, please respond by cc:mail that you accept the dispostion and that the RCR is closed out.

Thanks,

Larry Johnson

376-8807

$\ll$ File: TABDISP.RCR $\gg$ 


\section{REVIEW COMMENT RECORD (RCR)}

\begin{tabular}{|c|c|}
\hline $\begin{array}{c}\text { 1. Date } \\
1 / 6 / 99\end{array}$ & $\begin{array}{c}\text { 2. Review No. } \\
6-4\end{array}$ \\
\hline $\begin{array}{c}\text { 3. Project No. } \\
\text { PFP FSAR }\end{array}$ & 4. Page 1 of 1 \\
\hline
\end{tabular}

5. Document Number(s)/Title(s)

$$
\text { HNF-SD-CP-SAR-021 }
$$

\begin{tabular}{l|l}
$\begin{array}{l}\text { 6. Program/Project/ } \\
\text { Bui lding Number } \\
\text { PFP FSAR }\end{array}$ & 7. Reviewer \\
& H Risenmay
\end{tabular}

10. Agreement with indicated comment disposition(s)

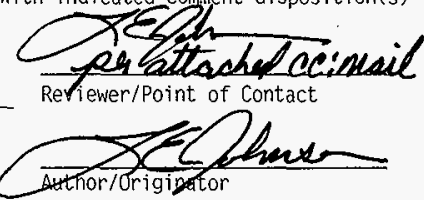

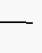

Author/origipator

\section{Organization/Group \\ PFP Process \\ Engineering}

9. Location/Phone

11. CLOSED

17. Comment Submittal Approval:

Organization Manager (Optional)

\section{$1 / 299$}

$\frac{1}{d} / 799$
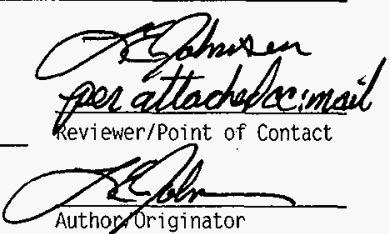

$\underset{1}{\sigma \infty}$

12. 13. Comment(s)/Discrepancy(s) (Provide technical justification

Ite for the comment and detailed recommendation of the action required

$\mathrm{m}$ to correct/ resolve the discrepancy/problem indicated.) Chapter 6

1. Comments on Chapter 6 received as redline markups.

\begin{tabular}{|l|l|l}
\hline $\begin{array}{l}\text { 14. } \\
\text { Hold } \\
\text { Point }\end{array}$ & $\begin{array}{l}\text { 15. Disposition (Provide justification if NOT } \\
\text { accepted.) }\end{array}$ & $\begin{array}{l}\text { l6. } \\
\text { Statu } \\
\text { s }\end{array}$ \\
\hline & & \\
\hline & Comments incorporated as appropriate. & \\
\hline & & \\
\hline & & \\
\hline & & \\
\hline & & \\
\hline & & \\
\hline & & \\
\hline
\end{tabular}




\title{
Johnson, LE (Safety Analysis)
}

From:

Sent:

To:

Subject:
Risenmay, Howard R (Rees)

Wednesday, January 06, 1999 12:23 PM

Johnson, LE (Safety Analysis); Gibson, Mark W

RE: PFP FSAR chapter 6 comments

I accept the disposition described below and it can be closed out.

HC. Qbees Risenmay

PFP Process Engineering

\author{
From: Johnson, L E (Safety Analysis) \\ Sent: Wednesday, January 06, 1999 10:31 AM! \\ To: Risenmay, Howard R (Rees) \\ Subject: PFP FSAR chapter 6 comments \\ Importance: High
}

Rees,

You submitted redline markup comments on chapter 6 . Jim Shapley has incorporated them as appropriate. I've filled out a RCR form indicating this, see attached. If this is acceptable, please respond by cc:mail that you accept the disposition and that it is closed out.

Thanks,

Larry Johnson

< File: HRDISP.RCR > 


\section{REVIEW COMMENT RECORD (RCR)}

\begin{tabular}{|l|l|}
\hline \begin{tabular}{|} 
1. Date \\
$1 / 6 / 99$
\end{tabular} & 2. Review No. \\
\hline $\begin{array}{c}\text { 3. Project No. } \\
\text { PFP FSAR }\end{array}$ & 4. Page \\
\hline
\end{tabular}

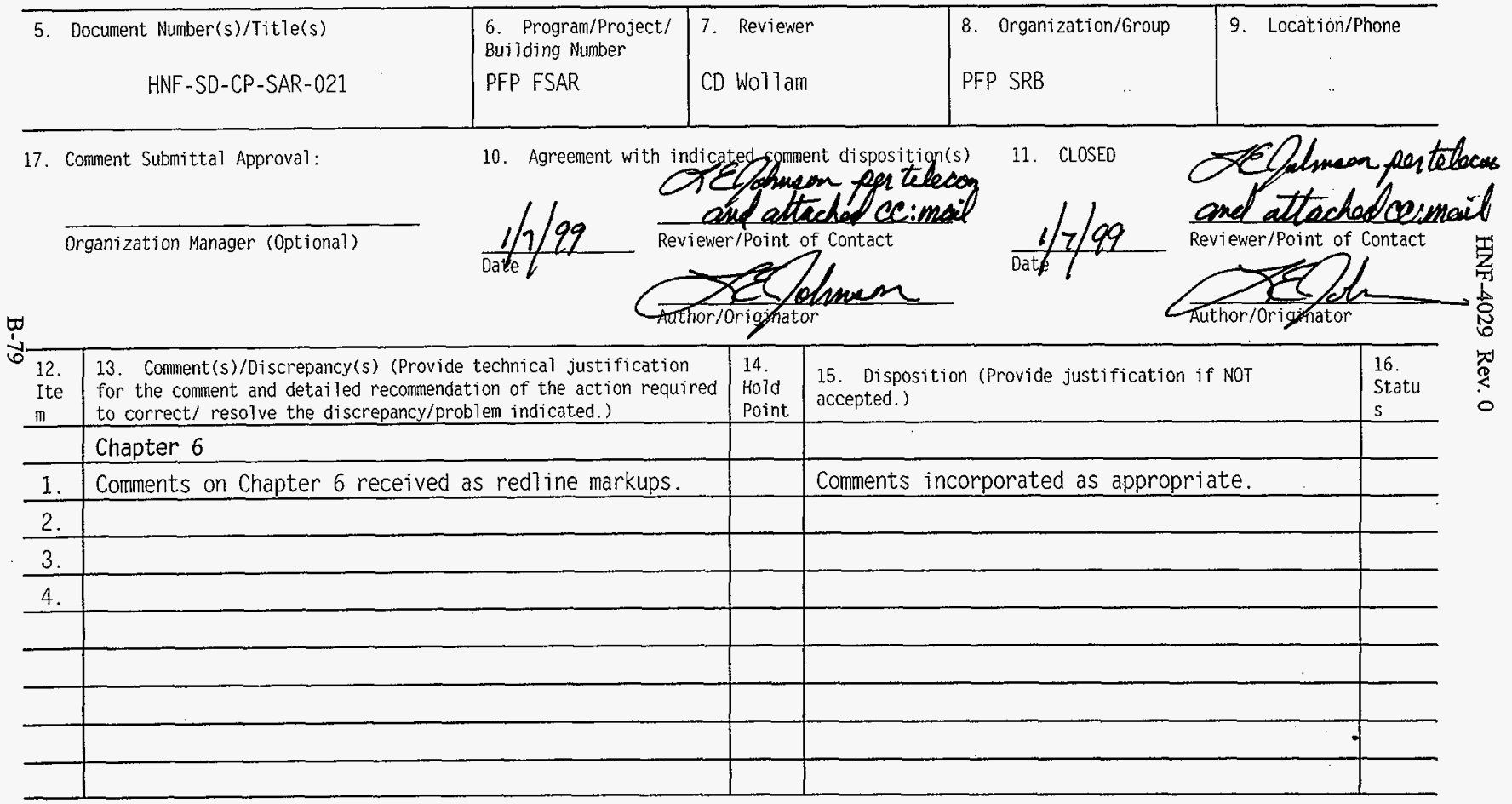


Johnson, LE (Safety Analysis)

$\begin{array}{ll}\text { From: } & \text { Wollam, C D (Chris) } \\ \text { Sent: } & \text { Wednesday, January 06, 1999 2:39 PM } \\ \text { To: } & \text { Johnson, L E (Safety Analysis) } \\ \text { Subject: } & \text { RE: PFP FSAR Chapter } 6 \text { Comments }\end{array}$

Larry,

I discussed my comments with Jim last week and reviewed these RCRs. These responses are adequate.

CDW

$\begin{array}{ll}\text { From: } & \text { Johnson, L E (Safety Analysis) } \\ \text { Sent: } & \text { Wednesday, January O6, 1999 10:59 AM } \\ \text { To: } & \text { Wollam, CD (Chris) } \\ \text { Subject: } & \text { PFP FSAR Chapter } 6 \text { Comments } \\ \text { Importance: } & \text { High }\end{array}$

Chris,

You submitted redline markup and cc:mail comments on Chapter 6 . Jim Shapley has incorporated them as appropriate. I've filled out RCR forms for each, see attached. Please let me know if these look acceptable, i'll be seeking your approval in the next few days.

Thanks for your support,

Larry Johnson

376-8807

$\ll$ File: CDW1DISP.RCR $\gg<$ File: CDWDISP.RCR $\gg$ 


\begin{tabular}{|l|l|l|}
\hline \multirow{2}{*}{ REVIEW COMMENT RECORD (RCR) } & $\begin{array}{l}\text { 1. Date } \\
1 / 6 / 99\end{array}$ & $\begin{array}{r}\text { Review No. } \\
6-3\end{array}$ \\
\cline { 2 - 4 } & $\begin{array}{l}\text { 3. Project No. } \\
\text { PFP FSAR }\end{array}$ & 4. Page \\
\hline
\end{tabular}

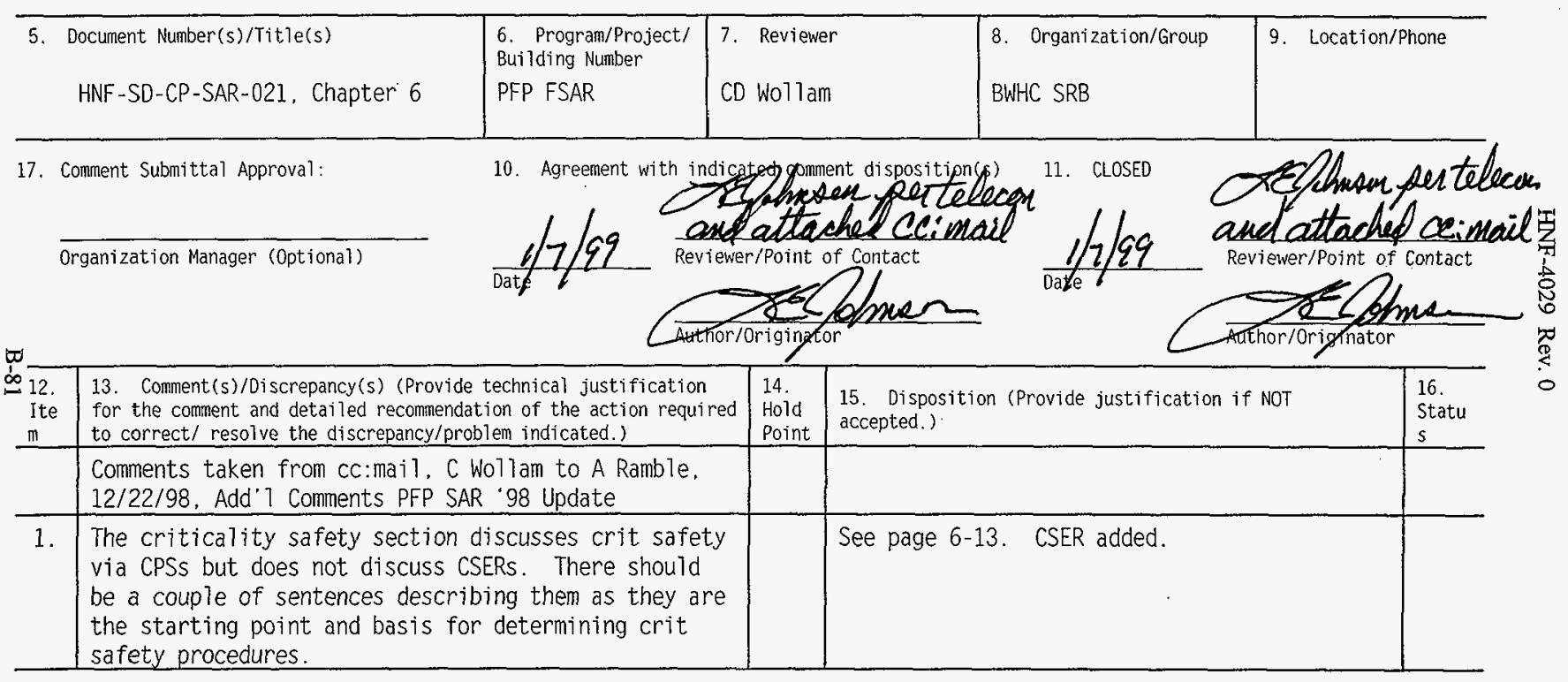




\section{REVIEW COMMENT RECORD (RCR)}

\begin{tabular}{|c|l|}
\hline $\begin{array}{c}\text { 1. Date } \\
1 / 6 / 99\end{array}$ & $\begin{array}{l}\text { 2. Review No. } \\
6-3\end{array}$ \\
\hline $\begin{array}{c}\text { 3. Project No. } \\
\text { PFP FSAR }\end{array}$ & $\begin{array}{l}\text { 4. Page } \\
2 \text { of } 2\end{array}$ \\
\hline
\end{tabular}

\begin{tabular}{|c|c|c|c|c|}
\hline $\begin{array}{l}12 . \\
\text { Ite } \\
\text { m }\end{array}$ & $\begin{array}{l}\text { 13. Comment(s)/Discrepancy(s) (Provide technical justification } \\
\text { for the comment and detaifed recommendation of the action required } \\
\text { to correct/ resolve the discrepancy/problem indicated.) }\end{array}$ & $\begin{array}{l}14 . \\
\text { Hold } \\
\text { Point } \\
\end{array}$ & $\begin{array}{l}\text { 15. Disposition (Provide justification if NOT } \\
\text { accepted.) }\end{array}$ & $\begin{array}{l}16 . \\
\text { Statu } \\
\text { s }\end{array}$ \\
\hline 2. & $\begin{array}{l}\text { Discussions of emergency backup fans should be: IS- } \\
\text { Steam powered fans: WILL BE- Electric powered fans. } \\
\text { This equipment is too important to describe the } \\
\text { modification as complete before it is. DOE guidance } \\
\text { documents seems clear on this point (they provide a } \\
\text { grace period of } 6 \text { mo. BEFORE sending the document to } \\
\text { them) }\end{array}$ & & $\begin{array}{l}\text { Directed to leave as is per A Ramble cc:mail } \\
\text { dated } 12 / 29 / 98 \text {. Will add commitment to } \\
\text { complete upgrade by June, } 1999 \text {. }\end{array}$ & \\
\hline \multicolumn{5}{|l|}{3.} \\
\hline \multicolumn{5}{|l|}{4.} \\
\hline & & & & \\
\hline & & & & \\
\hline & & & & \\
\hline & & & & \\
\hline & & & & \\
\hline & & & & \\
\hline & & & & \\
\hline & & & & \\
\hline & & & & \\
\hline & & & & \\
\hline & & & & \\
\hline & & & & \\
\hline
\end{tabular}


Johnson, LE (Safety Analysis)

$\begin{array}{ll}\text { From: } & \text { Wollam, C D (Chris) } \\ \text { Sent: } & \text { Wednesday, January 06, 1999 2:39 PM } \\ \text { To: } & \text { Johnson, LE (Safety Analysis) } \\ \text { Subject: } & \text { RE: PFP FSAR Chapter } 6 \text { Comments }\end{array}$

Larry,

I discussed my comments with Jim last week and reviewed these RCRs. These responses are adequate. CDW

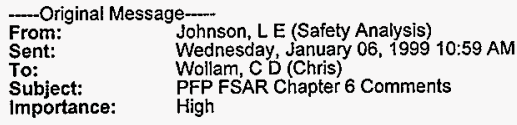

\section{Chris,}

You submitted redline markup and cc:mail comments on Chapter 6 . Jim Shapley has incorporated them as appropriate. l've filled out RCR forms for each, see attached. Please let me know if these look acceptable, l'll be seeking your approval in the next few days.

Thanks for your support,

Larry Johnson

376-8807

$\ll$ File: CDW1DISP.RCR $\gg \ll$ File: CDWDISP.RCR $\gg$ 


\section{REVIEW COMMENT RECORD (RCR)}

\begin{tabular}{|c|l|}
\hline $\begin{array}{c}\text { 1. Date } \\
1 / 6 / 99\end{array}$ & $\begin{array}{l}\text { 2. Review No. } \\
6-6\end{array}$ \\
\hline $\begin{array}{c}\text { 3. Project No. } \\
\text { PFP FSAR }\end{array}$ & 4. Page \\
& 1 of 1 \\
\hline
\end{tabular}

5. Document Number(s)/Title(s)

HNF - SD-CP-SAR-021
6. Program/Project/ Building Number

PFP FSAR

10. Agreement with indicated comment disposition(s)

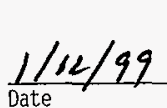
Date

Organization Manager (Optional)

$\infty$

$\infty$\begin{tabular}{l|l}
$\infty$ & 13. Comment(s)/Discrepancy(s) (Provide technical justification
\end{tabular}

Ite for the comment and detailed recommendation of the action required

$m$ to correct/ resolve the discrepancy/problem indicated.)

Chapter 6

1. Comments on Chapter 6 received as redline markups.

\begin{tabular}{c|c|}
\hline 2. & \\
\hline 3. & \\
\hline 4. & \\
\hline & \\
\hline & \\
\hline & \\
\hline & \\
\hline
\end{tabular}

7. Reviewer

RD Redekopp

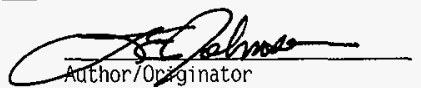

8. Organization/Group

PFP Operations

\section{CLOSED}

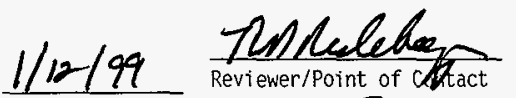

Date Reviewer/Point of CAact

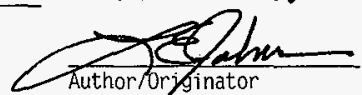

Author/Orjoinator

\begin{tabular}{|l|l|l}
\hline $\begin{array}{l}\text { Hoid } \\
\text { Point }\end{array}$ & $\begin{array}{l}\text { 15. Disposition (Provide justification if NOT } \\
\text { accepted.) }\end{array}$ & $\begin{array}{l}16 . \\
\text { Statu } \\
\text { s }\end{array}$ \\
\hline & & \\
\hline & Comments incorporated as appropriate. & \\
\hline & & \\
\hline & & \\
\hline & & \\
\hline & & \\
\hline
\end{tabular}




\begin{tabular}{|c|l|l|}
\hline \multirow{2}{*}{ REVIEW COMMENT RECORD (RCR) } & $\begin{array}{l}\text { 1. Date } \\
12 / 22 / 98\end{array}$ & $\begin{array}{c}\text { 2. Review No. } \\
\text { jpk.ch6 }\end{array}$ \\
\cline { 2 - 4 } & $\begin{array}{l}\text { 3. Project No. } \\
\text { PFP FSAR }\end{array}$ & $\begin{array}{l}4 . \text { Page } \\
1 \text { of } 3\end{array}$ \\
\hline
\end{tabular}

5. Document Number(s)/Title(s)

WHC-SD-CP-SAR-021 Draft Rev. 1

Plutonium Finishing Plant Final Safety Analysis Report Chapter 6

17. Comment Submittal Approval:

Organization Manager (Optionai)

$\varpi$

\begin{tabular}{l|ll}
$\infty$ \\
$\infty$
\end{tabular} $12 . \quad$ 13. Comment(s)/Discrepancy(s) (Provide technical justification

Ite for the comment and detailed recommendation of the action required

$\mathrm{m}$ to correct/ resolve the discrepancy/problem indicated.)

1 Page 6-9. 6.2.5.1. 3rd Para.: DELETE it and all of its' bullets. Chapters 5 and 8 , adequately cover this subject.

2

6.2.5.2.1, 2nd Para., 6th Sentence: DELETE "either PR containers or"

3 Page 6-21, 6.3.3.1.1, 1st Sentence: DELETE "236-Z and", CHANGE "Buildings" to "Building" CHANGE last sentence to "WHC-SD-CP-OSR-010. Administrative Control 5.22. Table 5.22-1 provides the most current listing of active and inactive gloveboxes"

\begin{tabular}{|l|l|l} 
7. Reviewer & $\begin{array}{l}\text { 8. Organization/Group } \\
\text { J.P. King }\end{array}$ & 9. Location/Phone \\
PFP Ops $/ 15310$ & $270-Z / 373-5194$
\end{tabular}

11. CLOSED

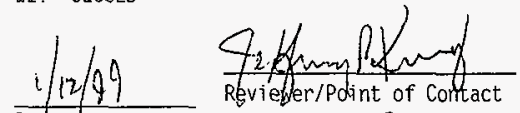
Date

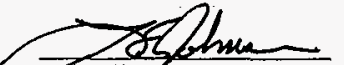
Author/0rj/ginator

\begin{tabular}{|l|l|l}
\hline $\begin{array}{l}14 . \\
\text { Hold } \\
\text { Point }\end{array}$ & $\begin{array}{l}\text { 15. Disposition (Provide justification if NOT } \\
\text { accepted.) }\end{array}$ & $\begin{array}{l}16 . \\
\text { Statu } \\
\text { s }\end{array}$ \\
\hline & $\begin{array}{l}\text { Chapter 4 covers criteria - delete in } \\
\text { chapter 6. }\end{array}$ & \\
\hline $\begin{array}{l}\text { Text changed as requested. } \\
\text { - Added statement that current list of } \\
\text { active and inactive gloveboxes is in OSR } \\
\text { document. }\end{array}$ & \\
\hline
\end{tabular}




\begin{tabular}{|c|l|l|}
\hline \multirow{2}{*}{ REVIEW COMMENT RECORD (RCR) } & $\begin{array}{l}\text { 1. Date } \\
12 / 22 / 98\end{array}$ & $\begin{array}{c}\text { 2. Review No. } \\
\text { jpk. ch6 }\end{array}$ \\
\cline { 2 - 4 } & $\begin{array}{c}\text { 3. Project No. } \\
\text { PFP FSAR }\end{array}$ & $\begin{array}{l}\text { 4. Page } \\
2 \text { of } 3\end{array}$ \\
\hline
\end{tabular}

\begin{tabular}{|c|c|c|c|c|}
\hline $\begin{array}{l}12 . \\
\text { Ite } \\
\text { m }\end{array}$ & $\begin{array}{l}\text { 13. Comment(s)/Discrepancy(s) (Provide technical justification } \\
\text { for the comment and detailed recommendation of the action required } \\
\text { to correct/ resolve the discrepancy/problem indicated.) }\end{array}$ & $\begin{array}{l}14 . \\
\text { Hold } \\
\text { Point }\end{array}$ & $\begin{array}{l}\text { 15. Disposition (Provide justification if NOT } \\
\text { accepted.) }\end{array}$ & \begin{tabular}{|l|l}
6. \\
Statu \\
5
\end{tabular} \\
\hline 4 & $\begin{array}{l}\text { Page 6-39, 6.4.1.4.4. 6th Para.: CHANGE to } \\
\text { "Strategically located CAMs alarm if airborne } \\
\text { plutonium is detected in the work space and prompt } \\
\text { evacuation of the affected air space is required." } \\
\text { DELETE everything else. }\end{array}$ & & $\begin{array}{l}\text { Changed first sentence as suggested, deleted } \\
\text { second sentence, and left the rest the same. }\end{array}$ & \\
\hline 5 & $\begin{array}{l}\text { Page } 6-51,6.4 .1 .9 .4 .7 \text { th Para., 2nd Sentence: } \\
\text { CHANGE "calibrated" to "maintained" }\end{array}$ & & Text revised as requested. & \\
\hline 6 & $\begin{array}{l}\text { Page } 6-54,6.4 .2 .9 .1 .4 \text { th Sentence: INSERT "HA-22B" } \\
\text { immediately after HA-28. }\end{array}$ & & HA-22B added to text. & \\
\hline 7 & $\begin{array}{l}\text { Page } 6-54,6.4 .3 \text {, 4th Sentence: CHANGE to "WHC-SD- } \\
\text { CP-OSR-010. Administrative Control } 5.22 \text {. Table } 5.22 \text { - } \\
1 \text { provides the most current listing of active and } \\
\text { inactive gloveboxes" }\end{array}$ & & $\begin{array}{l}\text { Added new sentence stating that a current } \\
\text { list of the active and inactive gloveboxes } \\
\text { can be found in OSR-010. Table } 5-5 \text { is a } \\
\text { list of the dispersable Pu limits used at } \\
\text { the time of the SAR preparation and supports } \\
\text { the accident analysis. Table } 5-5 \text { does not } \\
\text { have to match OSR Table } 5.22-1 \text {. }\end{array}$ & \\
\hline 8 & $\begin{array}{l}\text { Page } 6-59,6.4 .3 .1,3 \text { rd Para.. RMA line conveyer } \\
\text { hood is incorrectly identified. CHANGE to "HA-10". }\end{array}$ & & Text revised as requested. & \\
\hline 9 & $\begin{array}{l}\text { Page } 6-91,6.6 .1 .3 .2 \text {, 4th Para., 7th Sentence: } \\
\text { DELETE entirely, it is a mess. Existing 8th } \\
\text { Sentence: REPLACE with "Upon actuation, facility } \\
\text { workers are trained to promptly evacuate the } \\
\text { affected air space. " DELETE "while holding their } \\
\text { breath" }\end{array}$ & & Text revised as requested. & \\
\hline
\end{tabular}




\begin{tabular}{|l|l|l|}
\hline REVIEW COMMENT RECORD (RCR) & $\begin{array}{l}\text { 1. Date } \\
12 / 22 / 98\end{array}$ & $\begin{array}{l}\text { Review No. } \\
\text { jpk. ch6 . }\end{array}$ \\
\cline { 2 - 3 } & $\begin{array}{c}\text { 3. Project No. } \\
\text { PFP FSAR }\end{array}$ \\
\hline
\end{tabular}

\begin{tabular}{|c|c|c|c|c|}
\hline $\begin{array}{l}12 . \\
\text { Ite } \\
\text { m }\end{array}$ & $\begin{array}{l}\text { 13. Comment(s)/Discrepancy(s) (Provide technical justification } \\
\text { for the comment and detailed recommendation of the action required } \\
\text { to correct/ resolve the discrepancy/problem indicated.) }\end{array}$ & $\begin{array}{l}14 . \\
\text { Hold } \\
\text { Point }\end{array}$ & $\begin{array}{l}\text { 15. Disposition (Provide justification if NOT } \\
\text { accepted.) }\end{array}$ & $\begin{array}{l}16 . \\
\text { Statu } \\
\text { s }\end{array}$ \\
\hline 10 & $\begin{array}{l}\text { Page 6-91. 6.6.1.3.3: DELETE everything after the } \\
\text { first sentence. REPLACE with "The small quantities } \\
\text { of chemicals remaining in the PRF tanks and process } \\
\text { lines will be managed and dispositioned in } \\
\text { accordance with HNF-2977. "Plutonium Reclamation } \\
\text { Facility (PRF. Building 236-Z) Layup Plan" BWHC. } \\
\text { 1998. }\end{array}$ & & Text revised as requested. & \\
\hline 11 & $\begin{array}{l}\text { Page F6-18, Figure } 6-18 \text {. DELETE. It adds no value } \\
\text { to this chapter. }\end{array}$ & & Will leave it for now. & \\
\hline & & & & \\
\hline
\end{tabular}




\section{REVIEW COMMENT RECORD (RCR)}

\begin{tabular}{|l|l|}
\hline $\begin{array}{c}\text { 1. Date } \\
1 / 13 / 99\end{array}$ & 2. Review No. \\
\hline $\begin{array}{c}\text { 3. Project No. } \\
\text { PFP FSAR }\end{array}$ & 4. Page \\
\hline
\end{tabular}

5. Document Number(s)/TitTe(s)

HNF-SD-CP-SAR-021, Chapter 7
6. Program/Project/ Bui lding Number

PFP FSAR

7. Reviewer

CD Wollam
8. Organization/Group

Technical

Integration and SRB

Chairman
17. Comment Submittal Approval:

Organization Manager (Optional)

$\varpi$

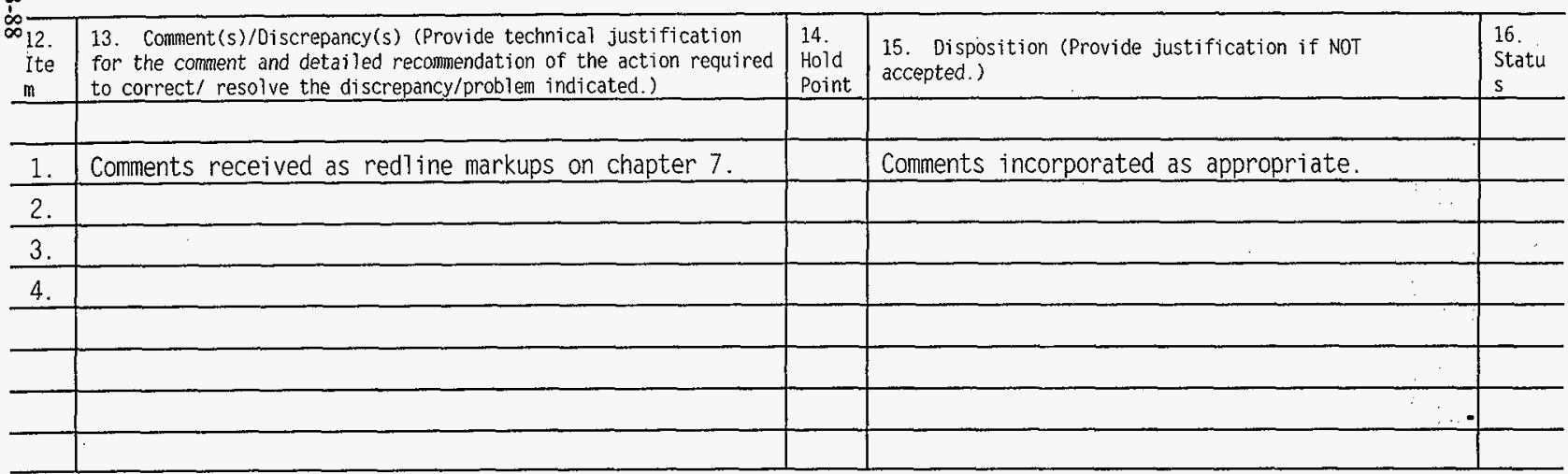

10. Agreement with indicated gomment dispogitign (s) 11. CLOSED
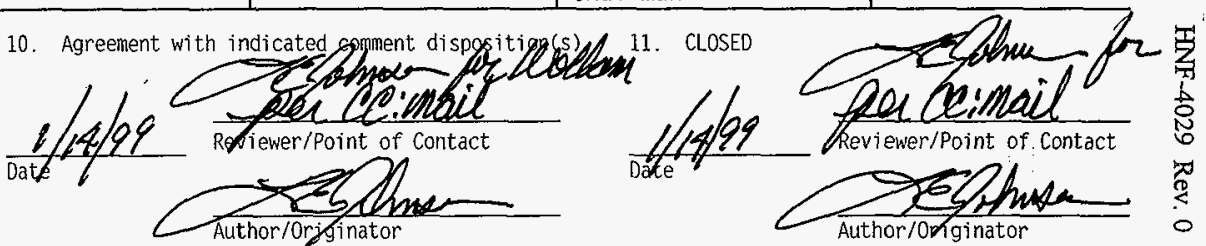
Johnson, LE (Safety Analysis)

From:

Sent:

To:

Wollam, C D (Chris)

Subject:

Thursday, January 14, 1999 1:15 PM

Johnsón, LE (Safety Analysis)

RE: PFP FSAR RCR Closeout

Larry,

I have discussed these with the authors and consider my comments resolved.

CDW

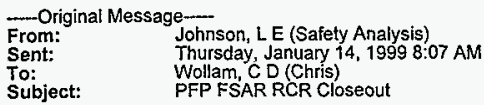

Sent: $\quad$ Thursday, January 14, 1999 8:07 AM

To: Wollam, CD (Chris)

Subject: $\quad$ PFP FSAR RCR Closeout

Chris,

I've attached files of the chapter 1,3 and 7 RCRs. If acceptable, please respond back that you consider the RCRs closed. Thanks for your support and patience during this functional review.

Larry Johnson

< File: CDW1DISP.RCR $\gg>$ File: CDW3DISP.RCR $\gg<<$ File:CDW7DISP.RCR $\gg>$

Note - these are WP 6.1 files 


\begin{tabular}{|c|c|c|}
\hline & $\begin{array}{r}\text { 1. Date } \\
12 / 30 / 98 \\
\end{array}$ & $\begin{array}{l}\text { 2. Review No. } \\
\text { JEB2, Ch. } 7\end{array}$ \\
\hline REVIEW COMMENI RECORD (RCR) & $\begin{array}{l}\text { 3. Project No, } \\
\text { PFP FSAR }\end{array}$ & 4. Page 1 of 2 \\
\hline
\end{tabular}

\begin{tabular}{l|l|l|l|l}
\hline 5. Document Number(s)/Title(s) & $\begin{array}{l}\text { 6. Program/Project/ } \\
\text { Building Number }\end{array}$ & 7. Reviewer & 8. organization/Group & 9. Location/Phone \\
WHC-SD-CP-SAR-021 Draft Rev. 1 & PFP & JE Bramson \\
Pluthonium Finishing Plant Final & Basis & PFP Environmental \\
Safety Analysis Report Chapter 7 & 270-Z/3/200W / & $373-1359$ \\
\hline
\end{tabular}
17. Comment Submittal Approval:
10. Agreement with indicated comment disposition(s)

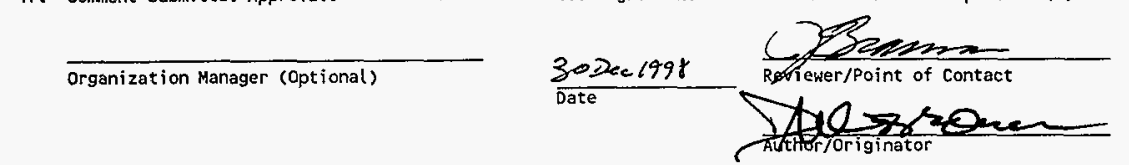

\section{CLOSED}

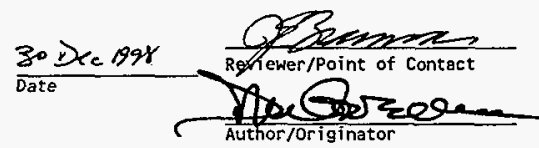

uthor/originator

\begin{tabular}{|c|c|c|c|c|}
\hline 12. & $\begin{array}{l}\text { 13. Comment(s)/Discrepancy(s) (Provide technical justification for the } \\
\text { comment and detailed recommendat ion of the action required to correct/ } \\
\text { resolve the discrepancy/problem indicated.) }\end{array}$ & $\begin{array}{l}14 . \\
\text { Hold } \\
\text { Point }\end{array}$ & 15. Disposition (Provide justification if NOT accepted.) & $\begin{array}{l}16 . \\
\text { Status }\end{array}$ \\
\hline & $\begin{array}{l}\text { [these comments were appended to an email dealing } \\
\text { with Mr. Bramson's review of comments from review } \\
\text { RCR \#SCA. Ch. } 7 \text { : } \\
\text { "The following comments are not in response to the } \\
\text { FDH RCR, but are changes identified during this } \\
\text { review of Chapter 7."] }\end{array}$ & & & \\
\hline 1 & $\begin{array}{l}\text { Page } 7-26,7.2 .2 .3 \\
\text { a. Designation of the } 216-2-13 \text { French Drain needs } \\
\text { to be changed to "Inactive". Dates of receipt } \\
\text { should show end date of } 1997 \text {. Description of wastes } \\
\text { received should be put into past tense. }\end{array}$ & & $\begin{array}{l}\text { Accept. Changed date to } 1997 \text { : added "In } \\
1998 \text {, steam condensate was rerouted to } \\
\text { discharge to LLWTF, and isolated from this } \\
\text { drain." }\end{array}$ & \\
\hline 1 & $\begin{array}{l}\text { Page } 7-26,7.2 .2 .3 \\
\text { b. Designation of the } 216-2-14 \text { French Drain needs } \\
\text { to be changed to "Active". Dates of receipt should } \\
\text { show } 1949 \text { to present. Description of wastes } \\
\text { received put into present tense. }\end{array}$ & & Accept. Changes made as noted. & \\
\hline
\end{tabular}




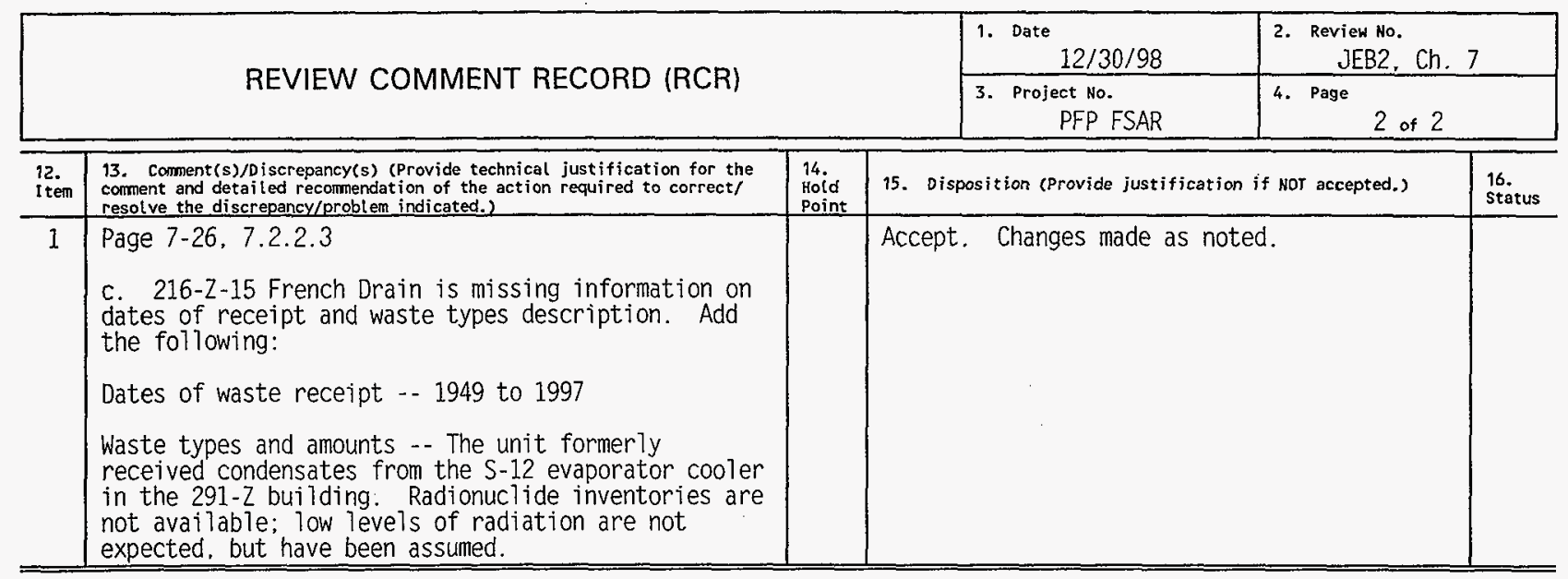

b 


\begin{tabular}{|c|c|c|}
\hline \multirow{2}{*}{ REVIEW COMMENT RECORD (RCR) } & $\begin{array}{l}\text { 1. Date } \\
12 / 22 / 98\end{array}$ & $\begin{array}{l}\text { 2. Review No. } \\
\text { JEB. Ch. } 7\end{array}$ \\
\hline & $\begin{array}{l}\text { 3. Project No. } \\
\text { PFP FSAR }\end{array}$ & 4. Page 1 of 3 \\
\hline
\end{tabular}

\begin{tabular}{|c|c|c|c|c|}
\hline $\begin{array}{l}\text { 5. Document Number(s)/Title(s) } \\
\text { WHC-SD-CP-SAR-021 Draft Rev. } 1 \\
\text { Plutonium Finishing Plant Final } \\
\text { Safety Analysis Report Chapter } 7\end{array}$ & $\begin{array}{l}\text { 6. Program/Project/ } \\
\text { Building Number } \\
\text { PFP } \\
\text { Authorization } \\
\text { Basis }\end{array}$ & $\begin{array}{l}\text { 7. Reviewer } \\
\text { JE Bramson }\end{array}$ & $\begin{array}{l}\text { 8. Organization/Group } \\
\text { PFP Environmental } \\
\text { Compliance }\end{array}$ & $\begin{array}{l}\text { 9. Location/Phone } \\
270-2 / 3 / 200 \mathrm{~W} / \\
373-1359\end{array}$ \\
\hline Organization Manager (optional) & $\begin{array}{l}\text { 10. Agreement with } \\
30 \mathrm{Dec} 1998\end{array}$ & wer/Point of contact & $\begin{array}{l}\text { 11. CLOSED } \\
30 D \times \text {. } 192 \gamma\end{array}$ & \\
\hline
\end{tabular}

\begin{tabular}{|c|c|c|c|c|}
\hline $\begin{array}{l}12 . \\
\text { It tem }\end{array}$ & $\begin{array}{l}\text { 13. Coment(s)/Discrepancy(s) (Provide technical justification for the } \\
\text { comment and detail ed recommendation of the action required to correct/ } \\
\text { resolve the discrepancy/problem indicated.) }\end{array}$ & $\begin{array}{l}14 . \\
\text { Hold } \\
\text { Point } \\
\end{array}$ & 15. Disposition (Provide justification if Nor accepted.) & $\begin{array}{l}16 . \\
\text { Status }\end{array}$ \\
\hline 1 & $\begin{array}{l}\text { Page 7-1, paragraph } 2 \\
\text { Re: references to HNF procedures. HNF-PRO-450, } \\
\text { "Air Quality - Radioactive Emissions". is draft as } \\
\text { far as I know. Recommend identifying draft } \\
\text { procedure as such when referencing. } \\
\text { Procedures HNF-PRO-452. "NEPA. SEPA. Cultural and } \\
\text { Natural Resources" - } 453 \text {, "Environmental } \\
\text { Notification and Reporting" - and 454. "Inactive } \\
\text { Waste Sites" are not realiy applicable to this } \\
\text { discussion and should not be included by } \\
\text { ". procedures HNF-PRO-450 through HNF-PRO-456..." } \\
\text { Procedure HNF-PRO-459. "Environmental Training", is } \\
\text { not applicable to discussion and should be deleted. } \\
\text { Procedure HNF-PRO-2695 is unknown. don't know that } \\
\text { it exists. Unless it can be demonstrated as } \\
\text { applicable, the reference should be deleted. } \\
\text { Suspect this may be a typographical error (after } \\
\text { seeing the references list). HNF-PRO-2595 addresses } \\
\text { Air Quality Program - Nonradioactive Emissions. }\end{array}$ & & $\begin{array}{l}\text { Accept all. } \\
\text { Sentence now reads: "PFP gaseous effluents, } \\
\text { liquid wastes, and solid wastes are managed } \\
\text { in accordance with procedures HNF-PRO-450 } \\
\text { (Draft). -451, -455, -456, -462, -2364, and } \\
-2595 . "\end{array}$ & \\
\hline
\end{tabular}




\begin{tabular}{|c|l|l|l|}
\hline \multirow{2}{*}{ REVIEW COMMENT RECORD (RCR) } & $\begin{array}{l}\text { 1. Date } \\
12 / 22 / 98\end{array}$ & $\begin{array}{l}\text { Review No. } \\
\text { JEB, Ch. } 7\end{array}$ \\
\cline { 2 - 4 } & $\begin{array}{l}3 . \text { Project No. } \\
\text { PFP FSAR }\end{array}$ & $\begin{array}{l}4 . \text { Page } \\
\text { of } 3\end{array}$ \\
\hline
\end{tabular}

\begin{tabular}{|c|c|c|c|c|}
\hline $\begin{array}{l}12 . \\
\text { item }\end{array}$ & $\begin{array}{l}\text { 13. Comment(s)/Discrepancy(s) (Provide technical justification for the } \\
\text { comment and detailed recormendation of the action required to correct/ } \\
\text { resolve the discrepancy/problem indicated.) }\end{array}$ & $\begin{array}{l}14 . \\
\text { Hold } \\
\text { Point. }\end{array}$ & 15. Disposition (Provide justification if NOT accepted.) & $\begin{array}{l}\text { 16. } \\
\text { Status }\end{array}$ \\
\hline 2 & $\begin{array}{l}\text { Page } 7-1 \text {, last paragraph. } \\
\text { Re: reference to HNF-PRO-2695. See comment in Item } \\
1 \text {. }\end{array}$ & & Accept. Deleted. & \\
\hline 3 & $\begin{array}{l}\text { Page } 7-3 \text {, Section } 7.1 .1 .2 .2 \text {, second bullet. } \\
\text { Delete reference to } 40 \text { CFR } 60 \text {. Not applicable. }\end{array}$ & & Accept. Deleted. & \\
\hline 4 & $\begin{array}{l}\text { Page } 7-3 \text {, Section } 7.1 .1 .2 .3 \text {, first bullet. } \\
\text { Delete reference to } 40 \text { CFR } 264 \text {. Not applicable. }\end{array}$ & & Accept. Deleted. & \\
\hline 5 & $\begin{array}{l}\text { Page 7-9. Section 7.1.2.1.1, first paragraph. } \\
\text { Delete sentence "This in-iine sampler is a } \\
\text { continuous-type. . DOE Order } 6430.1 A \text {." For the } \\
\text { purpose of the section discussion. this level of } \\
\text { detail and the degree of the statement are not } \\
\text { needed. APplicable criteria were } \\
\text { identified/discussed earlier. }\end{array}$ & & Accept. Deleted. & \\
\hline 6 & $\begin{array}{l}\text { page } 7-11 \text {, Section 7.1.3. second paragraph. } \\
\text { Add to end of paragraph. "To prevent the release of } \\
\text { NO above release limits, work control wi } 11 \text { ensure } \\
\text { that proper review and planning of waste treatment } \\
\text { activities is completed prior to performing the } \\
\text { work." }\end{array}$ & & Accept. Added sentence. & \\
\hline
\end{tabular}




\begin{tabular}{|c|c|c|}
\hline & $\begin{array}{l}\text { 1. Dare } \\
12 / 22 / 98\end{array}$ & $\begin{array}{l}\text { 2. Review No. } \\
\text { JEB, Ch. } 7\end{array}$ \\
\hline REVIEW COMMENT RECORD (RCR) & $\begin{array}{l}\text { 3. Project No. } \\
\text { PFP FSAR }\end{array}$ & 4. Page 3 of 3 \\
\hline
\end{tabular}

\begin{tabular}{|c|c|c|c|c|}
\hline $\begin{array}{l}12 . \\
\text { I tem }\end{array}$ & $\begin{array}{l}\text { 13. Comment( }(s) / 0 \text { iscrepancy(s) (Provide technical justification for the } \\
\text { corment and detailed recommendation of the action required to correct/ } \\
\text { resolve the discrepancy/problem indicated.) }\end{array}$ & $\begin{array}{l}14 . \\
\text { Hoid } \\
\text { Point }\end{array}$ & 15. Disposition (Provide justification if NOT accepted.) & $\begin{array}{l}16 . \\
\text { status }\end{array}$ \\
\hline 7 & $\begin{array}{l}\text { Page } 7-19 \text {. Section } 7.2 .2 .1 \text {, second paragraph } \\
\text { Move sentences beginning "The } 0-2 \text { and } 0-3 \text { Tines } \\
\text { go..." and "The D-1 and } 0-3 \text { drain line headers..." } \\
\text { to page } 7-31 \text {. Section } 7.2 .3 .2 .1 \text {. These sentences } \\
\text { dea } 1 \text { with wastewater discharge to LLWTF and not } \\
\text { radioactive discharges to } 241-7 \text {. }\end{array}$ & & $\begin{array}{l}\text { Accept. Deleted sentences on } 7-19 \text {, added } \\
\text { sentence to 2nd paragraph of } 7.2 .3 .2 .1 \text { : } \\
\text { "The } 0-2 \text { and } 0-3 \text { drain lines from the } \\
\text { basement of the } 234-52 \text { Building drain to the } \\
\text { LWWTF. The } 0-1 \text { and } 0-3 \text { drain line headers } \\
\text { in the } 236-2 \text { Building drain to manhole } Z-4 . "\end{array}$ & \\
\hline 8 & $\begin{array}{l}\text { Page 7-31, middle of page, last three bullets. } \\
\text { Delete bullets. The tanks discussed in these } \\
\text { bullets are PRF process tanks and not part of the } \\
\text { liquid waste treatment and control system discussed } \\
\text { in this section. If the bullets remain, then } \\
\text { distinguish these tanks as process control and } \\
\text { delete the word waste from the description. } \\
\text { (environmental compliance sensitivity to use of the } \\
\text { word). }\end{array}$ & & $\begin{array}{l}\text { Accept. Changed the word "waste" in these } \\
\text { three bullets to read "process control". }\end{array}$ & \\
\hline 9 & $\begin{array}{l}\text { Page } 7-31 \text {, Section } 7.2 .3 .2 .1 \text {. second paragraph. } \\
\text { In the last sentence is an example of an upset } \\
\text { contained in parenthesis. I suspect that the } \\
\text { example meant to indicate that the "influent" stream } \\
\text { had a pH of } 5 \text {, not the effluent stream. Is example } \\
\text { even necessary? }\end{array}$ & & Accept. Deleted parenthetical phrase. & \\
\hline 10 & $\begin{array}{l}\text { Page 7-35. Section 7.2.4. Tast paragraph. } \\
\text { Second to last sentence appears incomplete. }\end{array}$ & & $\begin{array}{l}\text { Accept. Changed last two sentences of } \\
\text { paragraph to read "The } 236-z \text { exhaust duct } \\
\text { sump is normally dry. If liquid should } \\
\text { accumulate, it must be sampled before the } \\
\text { sump contents can be transferred by jet pump } \\
\text { to manhole } Z-4 \text { for discharge into the } \\
\text { LLWTF." }\end{array}$ & \\
\hline
\end{tabular}




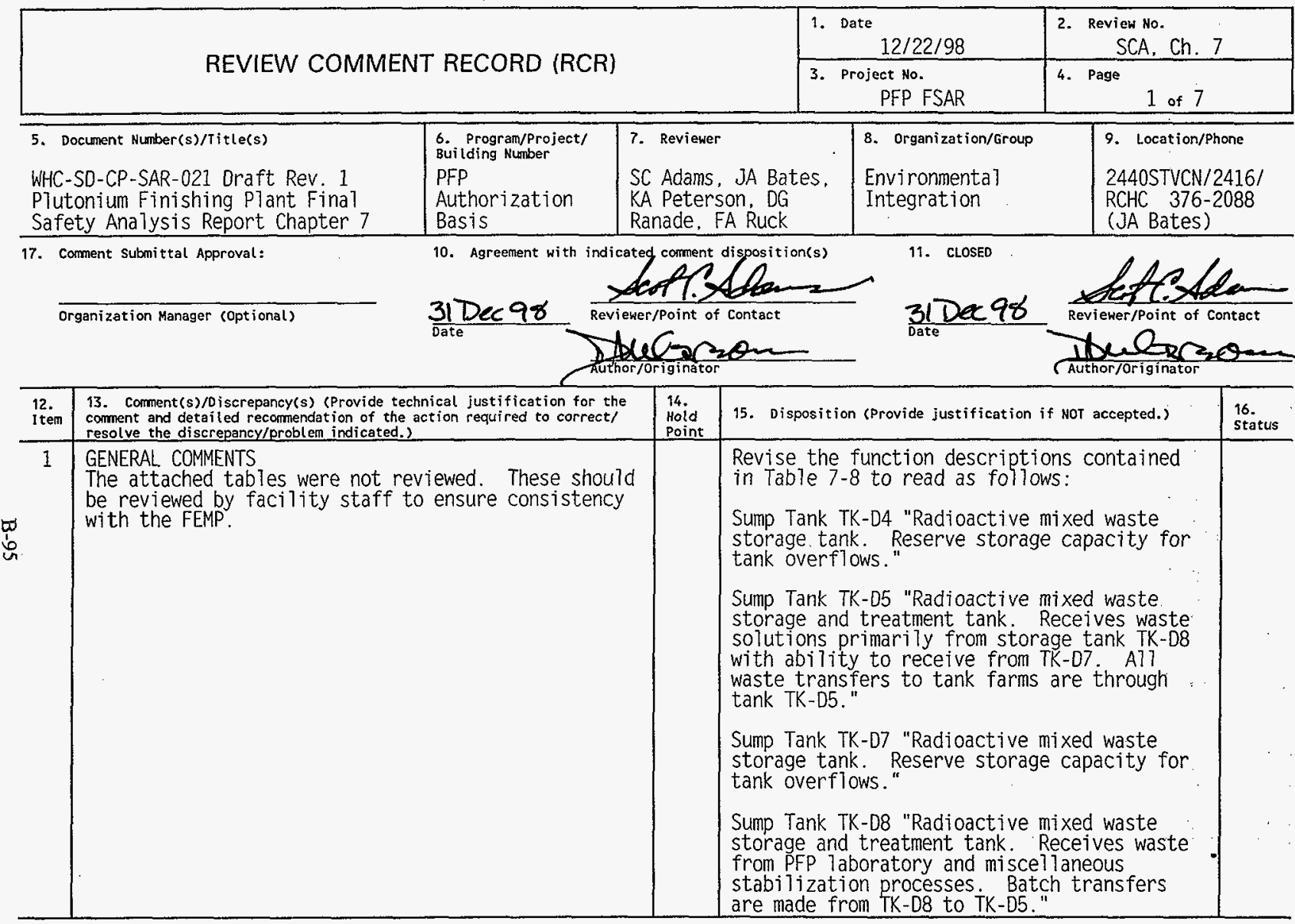




\begin{tabular}{|c|c|c|}
\hline & $\begin{array}{l}\text { 1. Date } \\
12 / 22 / 98\end{array}$ & $\begin{array}{l}\text { 2. Review No. } \\
\text { SCA, Ch. } 7\end{array}$ \\
\hline REVIEW COMMENT RECORD (RCR) & $\begin{array}{l}\text { 3. Project No. } \\
\text { PFP FSAR }\end{array}$ & $\begin{array}{l}\text { 4. Page } \\
2 \text { of } 7\end{array}$ \\
\hline
\end{tabular}

\begin{tabular}{|c|c|c|c|c|}
\hline $\begin{array}{l}2 . \\
\text { Item }\end{array}$ & $\begin{array}{l}\text { 13. Comment(s)/oiscrepancy(s) (Provide technical justification for the } \\
\text { comrent and detrailed recommendation of the action requi red to correct/) } \\
\text { resolve the discrepancy/problem indicated.) }\end{array}$ & $\begin{array}{l}14 . \\
\text { Hold } \\
\text { Point } \\
\end{array}$ & 15. Disposition (Provide justification if NOT accepted.) & $\begin{array}{l}16 . \\
\text { status }\end{array}$ \\
\hline 1 & $\begin{array}{l}\text { [John Bates \& Kirk Peterson] } \\
\text { R. } 7-1 \text {. Para. } 2 \\
\text { Some of these HNF-PRO's may be draft. Current } \\
\text { status should be verified. }\end{array}$ & & $\begin{array}{l}\text { Accept. Status verified and sentence } \\
\text { updated to reflect status and relevancy. }\end{array}$ & \\
\hline 2 & $\begin{array}{l}\text { [John Bates \& Kirk Peterson] } \\
\text { Section } 7.1 .1 .1 .2 \text {, bullet } 3 \\
\text { References to WHC documents should be reviewed to } \\
\text { ensure that such references are updated to reflect } \\
\text { new FDH/PHMC numbering. }\end{array}$ & & $\begin{array}{l}\text { a.Page } 7-2,7.1 .1 .1 .2,3 \text { rd bullet - change } \\
\text { WHC-EP-0476 to HNF-EP-0476. } \\
\text { D. Page 7-9, } 7.112 .1, \text { 2nd para - change } \\
\text { WHC-EP-0476 to HNF-EP-0476 and WHC-EP-0527 } \\
\text { to HNF-EP-0527. } \\
\text { c. Page R7-1, References, Documents. } \\
\text { Delete reference to WHC. ig98, The Plutonium } \\
\text { Finishing Plant Liquid Effluent Monitoring } \\
\text { P7an, WHC-SD-CM-EMP-001. This document was } \\
\text { replaced by WHC-EP-0476 as referenced on } \\
\text { page R7-3. } \\
\text { d. Page R7-3, - change WHC-EP-0476 to } \\
\text { HNF-EP-0476 and WHC-EP-0527 to HNF-EP-0527. }\end{array}$ & \\
\hline 3 & $\begin{array}{l}\text { [John Bates \& Kirk Peterson] } \\
\text { Section } 7.1 .1 .2 .2 \text { bul let } 2 \\
\text { 40CFR60 should be deleted }\end{array}$ & & Accept. Deleted. & \\
\hline 4 & $\begin{array}{l}\text { [John Bates \& Kirk Peterson] } \\
\text { Section } 7.1 .1,2.3 \text {, bullet } 1 \\
\text { 40CFR264 should be deleted }\end{array}$ & & Accept. Deleted. & \\
\hline 5 & $\begin{array}{l}\text { [John Bates \& Kirk Peterson] } \\
\text { Section } 7.1 .1 .5 .9 \\
\text { There is a draft PRO- } 450 \text { that relates to that. The } \\
\text { PRO will be a site-wide control. This also relates } \\
\text { to HEPA VACS used outdoors or otherwise non-vented } \\
\text { (powered ventilation) areas. This conment relates } \\
\text { to some planned cleanup activities. }\end{array}$ & & $\begin{array}{l}\text { Accept. Added citation to HNF-PRO-450 } \\
\text { (Draft). }\end{array}$ & \\
\hline
\end{tabular}




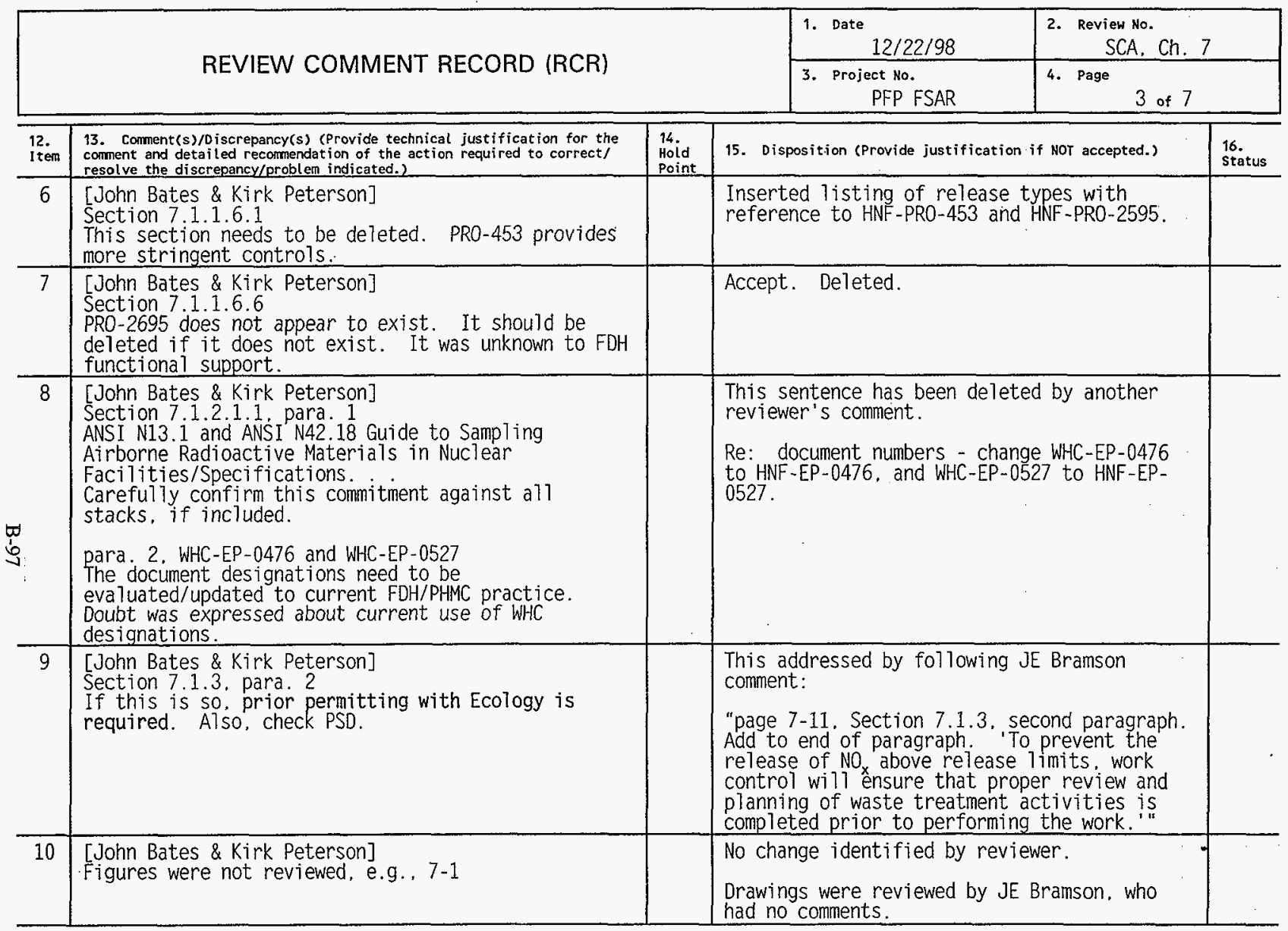




\begin{tabular}{|c|l|l|l|}
\hline \multirow{2}{*}{ REVIEW COMMENT RECORD (RCR) } & $\begin{array}{l}\text { 1. Date } \\
12 / 22 / 98\end{array}$ & $\begin{array}{l}\text { 2. Review No. } \\
\text { SCA. Ch. } 7\end{array}$ \\
\cline { 2 - 4 } & $\begin{array}{c}\text { 3. Project No. } \\
\text { PFP FSAR }\end{array}$ & $\begin{array}{l}\text { 4. Page } \\
4 \text { of } 7\end{array}$ \\
\hline
\end{tabular}

\begin{tabular}{|c|c|c|c|c|}
\hline $\begin{array}{l}12 . \\
\text { I tem }\end{array}$ & $\begin{array}{l}\text { 13. Corment(s)/D iscrepancy(s) (Provide technical justification for the } \\
\text { corment and detailed recomendation of the action required to correct/ } \\
\text { resolve the discrepancy/problem indicated.) }\end{array}$ & $\begin{array}{l}14 . \\
\text { Hoid } \\
\text { Point }\end{array}$ & 15. Disposition (Provide justification if Nor accepted.) & $\begin{array}{l}16 . \\
\text { Status }\end{array}$ \\
\hline 1 & $\begin{array}{l}\text { [Digambar Ranada] } \\
\text { This section should be compared against the FEMP. } \\
\text { The FEMP was not available to the reviewer. The } \\
\text { drawings should be compared with the discussion on } \\
\text { manholes. }\end{array}$ & & $\begin{array}{l}\text { No change identified by reviewer. } \\
\text { Drawings were reviewed by JE Bramson, who } \\
\text { had no comments. }\end{array}$ & \\
\hline 2 & $\begin{array}{l}\text { [Digambar Ranada] } \\
\text { Section } 7.2 .2 .1 \text {. para. } 2 \\
\text { Shouldn't the reference to } 0-1 \text { be } 0-2 \text { ? } 0-1 \text { may not } \\
\text { be active. }\end{array}$ & & $\begin{array}{l}\text { This section has been corrected by another } \\
\text { reviewer's comment. }\end{array}$ & \\
\hline
\end{tabular}

$\square$
1
0 


\begin{tabular}{|c|c|c|}
\hline \multirow{2}{*}{ REVIEW COMMENT RECORD (RCR) } & $\begin{array}{l}\text { 1. Date } \\
12 / 22 / 98\end{array}$ & $\begin{array}{c}\text { 2. Review No. } \\
\text { SCA. Ch. } 7\end{array}$ \\
\cline { 2 - 4 } & $\begin{array}{c}\text { 3. Project No. } \\
\text { PFP FSAR }\end{array}$ & $\begin{array}{l}\text { 4. Page } \\
5 \text { of } 7\end{array}$ \\
\hline
\end{tabular}

\begin{tabular}{|c|c|c|c|c|}
\hline $\begin{array}{l}\text { 12. } \\
\text { Item }\end{array}$ & $\begin{array}{l}\text { 13. Comment(s)/Discrepancy(s) (Provide technical justification for the } \\
\text { comentent and detai leded recomendation of the action requi red to correct/ } \\
\text { resolve the discrepancy/problem indicated.) }\end{array}$ & $\begin{array}{l}14 . \\
\text { Hold } \\
\text { Point }\end{array}$ & 15. Disposition (Provide justification if NOT accepted.) & $\begin{array}{l}16 . \\
\text { status }\end{array}$ \\
\hline $\begin{array}{l}0 \\
0 \\
0 \\
0\end{array}$ & $\begin{array}{l}\text { [Digambar Ranada] } \\
\text { Figures were not reviewed. The facility staff need } \\
\text { to ensure that these are accurate. }\end{array}$ & & 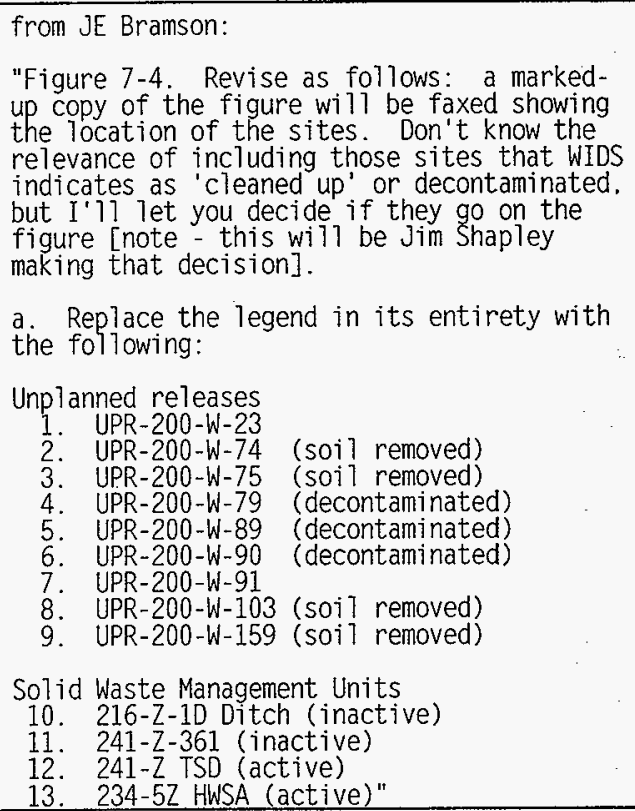 & \\
\hline 4 & $\begin{array}{l}\text { [Digambar Ranada] } \\
\text { Recently, lots more wIDS sites were added for French } \\
\text { drains. Facility staff need to ensure Figure } 7-3 \text {. }\end{array}$ & & $\begin{array}{l}\text { from JE Bramson: } \\
\text { "Review of WIDS does not identify additional } \\
\text { drains to be listed for PFP." } \\
\text { No change identified by reviewer. }\end{array}$ & \\
\hline
\end{tabular}




\begin{tabular}{|c|l|l|}
\hline \multirow{2}{*}{ REVIEW COMMENT RECORD (RCR) } & $\begin{array}{l}\text { 1. Date Review No. } \\
\text { SCA. Ch. } 7\end{array}$ \\
\cline { 2 - 4 } & $\begin{array}{c}3 . \text { Project No. } \\
\text { PFP FSAR }\end{array}$ & $\begin{array}{l}\text { 4. Page } \\
6 \text { of } 7\end{array}$ \\
\hline
\end{tabular}

\begin{tabular}{|c|c|c|c|c|}
\hline $\begin{array}{l}12 . \\
\text { Item }\end{array}$ & $\begin{array}{l}\text { 13. Comment(s)/0iscrepancy(s) (Provide technical justification for the } \\
\text { comment and detailed recommendation of the action required to correct/ } \\
\text { resolve the discrepancy/problem indicated.) }\end{array}$ & $\begin{array}{l}14 . \\
\text { Hoid } \\
\text { Point }\end{array}$ & 15. Disposition (Provide justification if NOT accepted.) & $\begin{array}{l}16 . \\
\text { status }\end{array}$ \\
\hline 1 & $\begin{array}{l}\text { [Scot Adams \& Fred Ruck] } \\
\text { Section } 7.3 \text {, bullet } 3 \\
\text { Replace definition per DOE/RL-91-28, Rev. } 4,5 / 98 \\
\text { "Mixed Waste - As defined in WAC- } 173-303-040 \text {, means } \\
\text { a dangerous, extremely hazardous, or acutely } \\
\text { hazardous waste that contains both a nonradioactive } \\
\text { hazardous component and, as defined by } 10 \text { CFR20.1003, } \\
\text { source, special nuclear, or by-product materiai } \\
\text { subject to the Atomic Energy Act." }\end{array}$ & & Accept. Comment incorporated as noted. & \\
\hline 2 & $\begin{array}{l}\text { [Scot Adams \& Fred Ruck] } \\
\text { Section 7.3.1 } \\
\text { Recommendation: Cite DOE/WIPP-069, Rev. 5, the WIPP } \\
\text { WAC. }\end{array}$ & & Accept. Cited. & \\
\hline$\frac{\pi}{8}$ & $\begin{array}{l}\text { [Scot Adams \& Fred Ruck] } \\
\text { Section } 7.3 .1 .1 \\
\text { Add waste designation and waste certification. }\end{array}$ & & $\begin{array}{l}\text { from JE Bramson: } \\
\text { "Applicable comments provided by Jeff King } \\
\text { and Gary Backlund on RCR \#jpk. Ch7" } \\
\text { Added bullet: "• Waste designation and } \\
\text { waste certification" }\end{array}$ & \\
\hline 4 & $\begin{array}{l}\text { [Scot Adams \& Fred Ruck] } \\
\text { Section } 7.3 .1 .3 \text { and Section } 7.3 .2 \text { and } 7.3 .4 .1 \text { (cited } \\
\text { in } 7.3 .2 \text { ) } \\
\text { There is a mixup in numbering. }\end{array}$ & & & \\
\hline 5 & $\begin{array}{l}\text { [Scot Adams \& Fred Ruck] } \\
\text { Section } 7.3 .4 .1 \text { Citation WHC-SP-1159 } \\
\text { This citation needs to be confirmed to ensure that } \\
\text { the latest WIPP WAC is addressed. The last WIPP WAC } \\
\text { revision included new mixed waste requirements. }\end{array}$ & & $\begin{array}{l}\text { Citation has been deleted per another } \\
\text { reviewer's comment. }\end{array}$ & \\
\hline 6 & $\begin{array}{l}\text { [Scot Adams \& Fred Ruck] } \\
\text { Section } 7.3 .5 \text {, bullets } 1 \& 2 \\
\text { The 1 imit is confusing or contradictory. }\end{array}$ & & $\begin{array}{l}\text { Accept. Added: "en drums other than PRF } \\
\text { drums" to first sentence. }\end{array}$ & \\
\hline
\end{tabular}




\begin{tabular}{|c|l|}
\hline $\begin{array}{c}\text { 1. Date } \\
12 / 22 / 98\end{array}$ & $\begin{array}{l}\text { 2. Review No. } \\
\text { SCA, Ch. } 7\end{array}$ \\
\hline $\begin{array}{c}\text { 3. Project No. } \\
\text { PFP FSAR }\end{array}$ & 4. Page 7 of 7 \\
\hline
\end{tabular}

\begin{tabular}{|c|c|c|c|c|}
\hline $\begin{array}{l}12 . \\
\text { I tem }\end{array}$ & $\begin{array}{l}\text { 13. Comment(s)/oiscrepancy(s) (Provide technical justification for the } \\
\text { comment and detailed recommendation of the action required to correct/ } \\
\text { resolve the discrepancy/problem indicated.) }\end{array}$ & $\begin{array}{l}14 . \\
\text { Hoid } \\
\text { Point }\end{array}$ & 15. Disposition (Provide justification if NOT accepted.) & $\begin{array}{l}16 . \\
\text { Status } \\
\end{array}$ \\
\hline 7 & $\begin{array}{l}\text { [Scot Adams \& Fred Ruck] } \\
\text { Section } 7.3 .5 \text {, page } 7-40 \text {, last line } \\
\text { Burial of TRU waste in a burial box appears to be a } \\
\text { past practice that is no longer compliant with } \\
\text { national direction. }\end{array}$ & & $\begin{array}{l}\text { from JE Bramson: } \\
\text { "Applicable comments provided by Jeff King } \\
\text { and Gary Backlund on RCR \#jpk.ch7" }\end{array}$ & \\
\hline 8 & $\begin{array}{l}\text { [Scot Adams \& Fred Ruck] } \\
\text { Section } 7.3 .5 \text {, page } 7.41 \text {. last paragraph } \\
\text { Burial of TRU waste in a burial box appears to be a } \\
\text { past practice that is no longer compliant with } \\
\text { national direction. }\end{array}$ & & $\begin{array}{l}\text { from JE Bramson: } \\
\text { "Applicable comments provided by Jeff King } \\
\text { and Gary Backlund on RCR \#jpk. Ch7" }\end{array}$ & \\
\hline 9 & $\begin{array}{l}\text { [Scot Adams \& Fred Ruck] } \\
\text { Section } 7.3 .6 .2 \text {, page } 7-42 \text {. last para. } \\
\text { Burial of lead should be confirmed against the } \\
\text { latest version of } 0063 \text {. }\end{array}$ & & $\begin{array}{l}\text { from JE Bramson: } \\
\text { "Applicable comments provided by Jeff King } \\
\text { and Gary Backlund on RCR \#jpk.ch7" }\end{array}$ & \\
\hline 10 & $\begin{array}{l}\text { [Scot Adams \& Fred Ruck] } \\
\text { Remember that this section is radioactive solid } \\
\text { waste. Routine disposal of batteries should not be } \\
\text { in this section. Hopefully, waste minimization will } \\
\text { result in the removal of contamination from those } \\
\text { batteries that dispositioned. }\end{array}$ & & Section deleted by other reviewer's comment. & \\
\hline 11 & $\begin{array}{l}\text { [Scot Adams \& Fred Ruck] } \\
\text { Section } 7.3 .6 .2 \text {, page } 7-43 \text {, para } 2,3,4 \text {, and } 5 \\
\text { These section need to be reviewed against the } \\
\text { current versions of the } 0063 \text { WAC and the WIPP WAC. }\end{array}$ & & $\begin{array}{l}\text { from JE Bramson: } \\
\text { "Applicable comments provided by Jeff King } \\
\text { and Gary Backlund on RCR \#jpk. Ch7" }\end{array}$ & \\
\hline 12 & $\begin{array}{l}\text { [Scot Adams \& Fred Ruck] } \\
\text { Section } 7.3 .8 \text {, para } 1 \\
\text { This section should be reviewed against current TRU } \\
\text { practices. Current } 1 y \text { most TRU waste is being } \\
\text { packaged to be certified for WIPP disposition, } \\
\text { according to the WIPP WAC. }\end{array}$ & & $\begin{array}{l}\text { from JE Bramson: } \\
\text { "Applicable comments provided by Jeff King } \\
\text { and Gary Backlund on RCR \#jpk.ch7" }\end{array}$ & \\
\hline 13 & $\begin{array}{l}\text { [Scot Adams \& Fred Ruck] } \\
\text { Figure 7-4: New waste sites may have been } \\
\text { associated with these facilities. New waste sites } \\
\text { were assigned to PHMC contractors. }\end{array}$ & & $\begin{array}{l}\text { from JE Bramson: } \\
\text { "See previous response to Ranada, item 3.". }\end{array}$ & \\
\hline
\end{tabular}




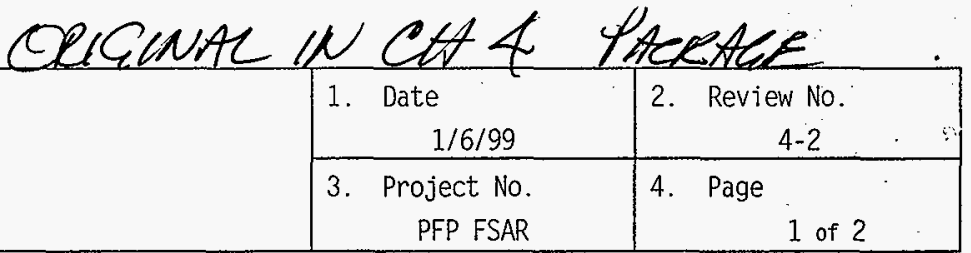

\begin{tabular}{|c|c|c|c|c|}
\hline 5. Document Number(s)/Title(s) & $\begin{array}{l}6 . \\
\text { Program/Project/ } \\
\text { Bui Tding Number } \\
\text { PFP FSAR }\end{array}$ & $\begin{array}{l}\text { 7. Reviewer } \\
\text { RD Keck }\end{array}$ & $\begin{array}{l}8 . \\
\text { Organization/Group } \\
\text { PFP Facility Systems } \\
\text { Engineering }\end{array}$ & $\begin{array}{l}9 . \\
\text { Location/Phone }\end{array}$ \\
\hline
\end{tabular}

17. Comment Submittal Approval:

$\frac{5}{1}$

Organization Manager (Optional)
10. Agreement with indicated comment disposition(s)

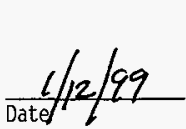

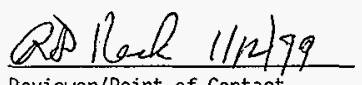
Reviewer/Point of Contact.

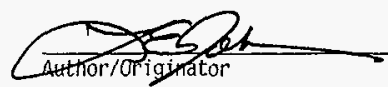

11. CLOSED

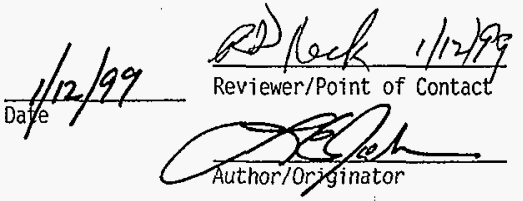

\begin{tabular}{l|l|l|l}
\hline 12 & $\begin{array}{l}\text { 13. Comment(s)/Discrepancy(s) (Provide technical } \\
\text { justification for the comment and detailed } \\
\text { recommendation of the action required to correct/ } \\
\text { resolve the discrepancy/problem indicated.) }\end{array}$ & $\begin{array}{l}14 . \\
\text { Hold } \\
\text { Poin } \\
t\end{array}$ & $\begin{array}{l}\text { 15. Disposition (Provide justification if } \\
\text { NOT accepted.) }\end{array}$ \\
\hline 1. & $\begin{array}{l}\text { FSAR comments relative to backup ventilation for } \\
234-52\end{array}$ & $\begin{array}{l}\text { statu } \\
\text { s }\end{array}$ \\
\hline
\end{tabular}




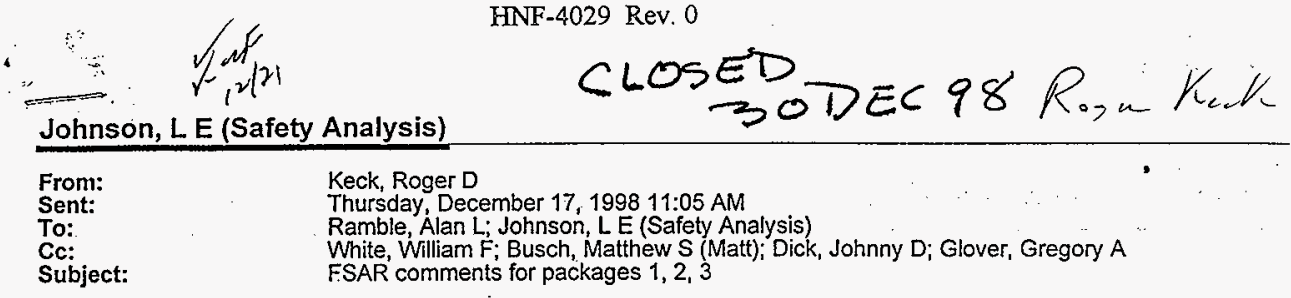

Al, The attached word file contains my comments for the subject packages. The big impact is the conversion from steam to electric backup ventilation. John Dick has reviewed my description of the differences. Roger

FSAR comments

relative to back...

Accept perTelecon

113330 Dec 98

- pe

B-103 
The backup ventilation will operate differently when using electrically powered fans instead of steam turbines.

With steam turbines, the backup ventilation fans do not start until the exhaust plenum pressure rises above $-3.5^{\prime \prime} \mathrm{wg}$ or on the loss of instrument air. Then both steam driven fans start.

With electric fans for backup, one of the fans will be run continuously under all ventilation and power conditions. If a failure in the operating backup fan is detected, the alternate backup fan will be started.

The following pages in the draft FSAR need to be changed to reflect this difference:

4-iii

4-15

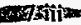

8-iii

$8-19$

$8-26$

$8-28$

Chapter 4, page T4-10 item 3 - this should be the public address system not the PAX system

Page T4-11 item 10 - the functional requirement for the backup power system should include providing backup power to the public address system. 


\begin{tabular}{|c|c|c|c|}
\hline \multirow{2}{*}{ REVIEW COMMENT RECORD (RCR) } & $\begin{array}{l}\text { 1. Date } 12 / 28 / 98 \\
\text { Peview No. } \\
\text { RDR. Ch. } 7\end{array}$ \\
\cline { 2 - 4 } & $\begin{array}{c}3 . \text { Project No. } \\
\text { PFP FSAR }\end{array}$ & $\begin{array}{c}\text { 4. Page } \\
1 \text { of } 1\end{array}$ \\
\hline
\end{tabular}

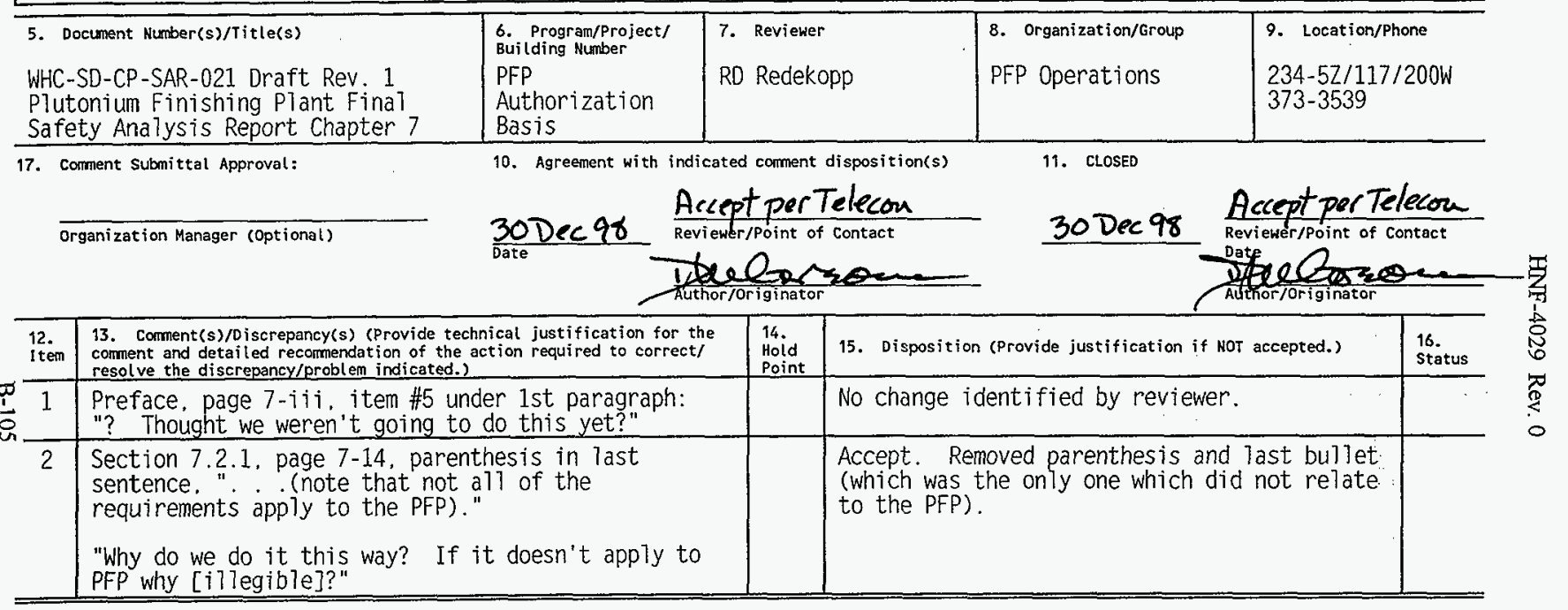




\begin{tabular}{|l|l|l|l|}
\hline \multirow{2}{*}{ REVIEW COMMENT RECORD (RCR) } & $\begin{array}{l}\text { 1. Date Review No. } \\
\text { TAB. Ch. } 7\end{array}$ \\
\cline { 2 - 4 } & $\begin{array}{c}\text { 3. Project No. } \\
\text { PFP FSAR }\end{array}$ & $\begin{array}{c}\text { 4. Page } \\
1 \text { of } 1\end{array}$ \\
\hline
\end{tabular}

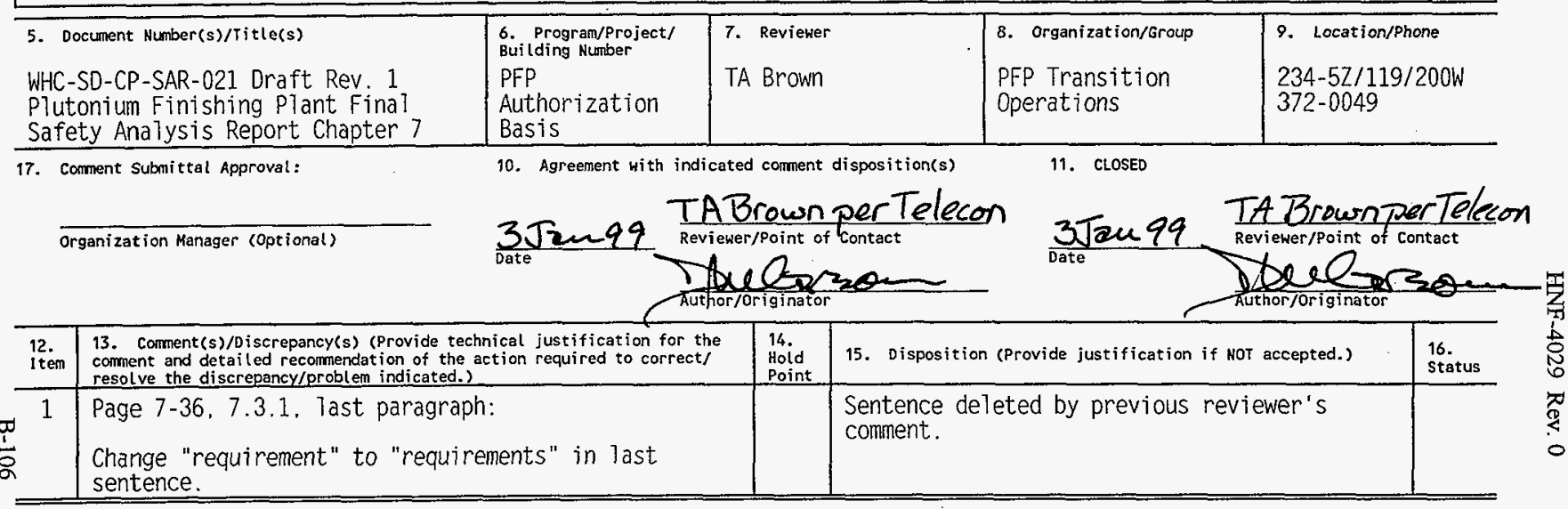




\section{REVIEW COMMENT RECORD (RCR)}

\section{Date}

3. Project No. PFP FSAR
2. Revien No. jpk.ch7

4. Page

1 of 9

\section{Document Number(s)/Title(s)}

WHC-SD-CP-SAR-021 Draft Rev. I

Plutonium Finishing Plant Final Safety Anaiysis Report Chapter 7

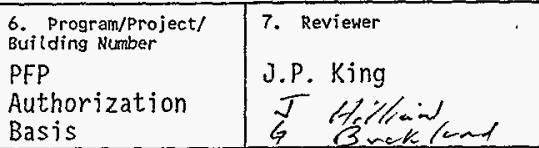

10. Agreement with indigated comment disposition(s)

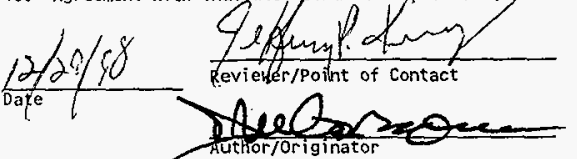

\section{Organization/Group}

PFP Ops./15310
9. Location/Phone

$270-Z / 373-5194$
17. Corment Submittal Approval:

Organization Manager (optional)

\begin{tabular}{|c|c|c|c|c|}
\hline $\begin{array}{l}12 . \\
\text { 1 ten }\end{array}$ & $\begin{array}{l}\text { 13. Comment(s)/Discrepancy(s) (Provide technical justification for the } \\
\text { coment and detailed recommendation of the action required to correct/ } \\
\text { resolve the discrepancy/problem indicated.) }\end{array}$ & $\begin{array}{l}14 . \\
\text { Hoid } \\
\text { Point }\end{array}$ & 15. Disposition (Provide justification if NOT accepted.) & $\begin{array}{l}16 . \\
\text { status }\end{array}$ \\
\hline 1 & $\begin{array}{l}\text { Page 7-iji PREFACE, lst Para.: ADD another item for } \\
\text { Revision; "Sanitary Sewer System to reflect the } \\
\text { change from the PFP sanitary drain tile field to the } \\
\text { 200-West Area Regional Drainfield." }\end{array}$ & & Acespt & \\
\hline 2. & $\begin{array}{l}\text { Page 7-iii, PREFACE, 2nd Para., 5th Sentence: } \\
\text { DELETE "operation and" from sentence. } \\
\text { While the essential function of the electrically } \\
\text { driven fans remains the same as for steam turbines, } \\
\text { their operation is significantly different. }\end{array}$ & & Tut is section rewis is & \\
\hline$\therefore$ & $\begin{array}{l}\text { Page 7-9, 7.1.2 3rd Para, 4th Sentence: END } \\
\text { SENTENCE AFTER "radioactive material". DELETE "and } \\
\text { have been isolated from the ventilation system". } \\
232-7 \text { hoods and gloveboxes are stili very much } \\
\text { connected (not isolated) from the ventilation } \\
\text { system. }\end{array}$ & & Accest & \\
\hline
\end{tabular}

11. CLOSED
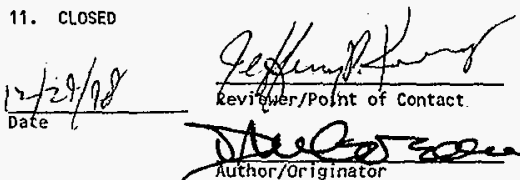


\begin{tabular}{|c|c|c|}
\hline \multirow{2}{*}{ REVIEW COMMENT RECORD (RCR) } & $\begin{array}{l}\text { 1. Date } \\
12 / 21 / 98\end{array}$ & $\begin{array}{l}\text { 2. Review Ho. } \\
\text { jpk.ch7 }\end{array}$ \\
\hline & $\begin{array}{l}\text { 3. Project Ho. } \\
\text { PFP FSAR }\end{array}$ & 4. Page \\
\hline
\end{tabular}

\begin{tabular}{|c|c|c|c|c|}
\hline $\begin{array}{l}12 . \\
\text { Item }\end{array}$ & $\begin{array}{l}\text { 13. Comment( }(s) / D \text { iscrepancy(s) (Provide technical justification for the } \\
\text { comment and detailed recomendation of the action required to correct/ } \\
\text { resolve the discrepancy/problem indicated.) }\end{array}$ & $\begin{array}{l}14 . \\
\text { Hold } \\
\text { Point }\end{array}$ & 15. Disposition (Provide justification if not accepted.) & $\begin{array}{l}16 . \\
\text { status }\end{array}$ \\
\hline 4. & $\begin{array}{l}\text { Page 7-10, 7.1.2.1.2, 4th Para.: DELETE first } \\
\text { sentence. Then COMBINE remainder of } 4 \text { th Para. with } \\
\text { Para } 3 . \\
\text { EBERLINE ATpha CAM detector design does not meet the } \\
\text { guidance of ANSI N13.1. Don't even try to make the } \\
\text { claim, there are too many articles and studies out } \\
\text { there that prove that it does not. }\end{array}$ & & $A(c y)$, & \\
\hline 5. & $\begin{array}{l}\text { Page } 7-12,7.1 .3 .1 .3, \text { 1st Para., lst Sentence: ADD } \\
\text { at end "and glovebox in building 241-ZA." }\end{array}$ & & $A c \cos t$ & \\
\hline 6. & $\begin{array}{l}\text { Page } 7-13,7.1 .3 .2,6 \text { th bullet: DELETE "some". It } \\
\text { is redundant with "some" contained at the end of } \\
\text { Sentence } 2 \text { immediately above the bulletized list. }\end{array}$ & & $A \cdot c$ & \\
\hline 7. & $\begin{array}{l}\text { Page } 7-19,7.2 .2,5 \text { th bullet: CHANGE to "Restroom, } \\
\text { shower, and } 7 \text { unchroom drains sent to the } 200 \text { West } \\
\text { Area Regional Drainfield." }\end{array}$ & & Accogot & \\
\hline 8. & $\begin{array}{l}\text { Page 7-21, 7.2.2.1.3, 3rd Para., } 1 \text { st and 2nd } \\
\text { Sentences: CHANGE "is" to "was" (past tense). } \\
\text { Alternatively, consider deleting discussion of } \\
\text { aluminum entirely. }\end{array}$ & & $A$ cesp $t$ & \\
\hline 9. & $\begin{array}{l}\text { Page } 7-23,7.2 .2 .1 .3, \text { 16th Para.: DELETE last } \\
\text { sentence concerning nitrate generation from MT } \\
\text { gloveboxes. }\end{array}$ & & $A_{c}$ enpt & \\
\hline
\end{tabular}




\begin{tabular}{|l|l|l|l|}
\hline \multirow{2}{*}{ REVIEW COMMENT RECORD (RCR) } & $\begin{array}{l}\text { 1. Date Review No. } \\
\text { jpk.ch7 }\end{array}$ \\
\cline { 2 - 4 } & $\begin{array}{c}\text { 3. Project No. } \\
\text { PFP FSAR }\end{array}$ & $\begin{array}{c}\text { 4. Page } \\
3 \text { of } 9\end{array}$ \\
\hline
\end{tabular}

\begin{tabular}{|c|c|c|c|c|}
\hline $\begin{array}{l}\text { 12. } \\
\text { Item }\end{array}$ & $\begin{array}{l}\text { 13. Comment (s)/oiscrepancy(s) (Provide technical justification for the } \\
\text { comment and detai iled recomentation of the action required to corrects } \\
\text { resolve the discrepancy/problen indicated.2 }\end{array}$ & $\begin{array}{l}14 . \\
\text { Hoid } \\
\text { Point }\end{array}$ & 15. Disposition (Provide justification if NoT accepted.) & $\begin{array}{l}\text { 16. } \\
\text { status }\end{array}$ \\
\hline 10. & $\begin{array}{l}\text { Page } 7-27,7.2 .2 .4 .1 \text { 2nd Sentence: CHANGE to "These } \\
\text { sanitary sewer systems take receive liquid from } \\
\text { restrooms, showers, and lunchroom sinks and dispose } \\
\text { of it through septic tanks, pump stations, and to } \\
\text { the } 2607-W 1 \text { regional drainfield located } \\
\text { approximately one half mile away, where it is } \\
\text { percolated into the soil." } \\
\text { This project is being completed as part of project } \\
L-281 \text {. }\end{array}$ & & $A<$ cgpt & \\
\hline 11. & $\begin{array}{l}\text { Page 7-28, 7.2.2.5 This Paragraph needs to be sp } 7 \text { it } \\
\text { into two, one for PRF Room 40, one for 234-5Z Rooms } \\
336 / 337 \text {. For PRF Room 40: All PRF processes are } \\
\text { currently inactive and not authorized for operation. } \\
\text { Chemicals remaining in the PRF tanks and process } \\
\text { lines will be managed and dispositioned in } \\
\text { accordance with HNF-2977, "P7utonium Reciamation } \\
\text { Facility (PRF, Building } 236-Z \text { ) Layup Plan" BWHC, } \\
\text { I998. Electrical to instrumentation in the room has } \\
\text { been isolated. } \\
\text { 234-5Z Rooms } 2336 / 337 \text { contain three active chemical } \\
\text { tanks that will be required to support future } \\
\text { material stabilization activities. }\end{array}$ & & Accept. & \\
\hline 12. & $\begin{array}{l}\text { Page 7-30, 7.2.3.1.1, 3rd Para., 1st sentence: } \\
\text { CHANGE "building" to "facility". } \\
\text { 244-TX is an underground storage vault with } \\
\text { associated instrumentation building and exhaust } \\
\text { system. "facility" is a more accurate description. }\end{array}$ & & Aecont. & \\
\hline $13 \cdot$ & $\begin{array}{l}\text { Page 7-31, 7.2.3.2.1, 1st Para., 2nd Sentence: } \\
\text { DELETE "drinking water". It is redundant with } \\
\text { "sanitary water". }\end{array}$ & & Acypt & \\
\hline
\end{tabular}




\begin{tabular}{|l|l|l|l|}
\hline \multirow{2}{*}{ REVIEW COMMENT RECORD (RCR) } & $\begin{array}{l}\text { 1. Date } 12 / 21 / 98 \\
12 . \text { Review No. } \\
\text { jpk.ch7 }\end{array}$ \\
\cline { 2 - 4 } & $\begin{array}{c}3 . \text { Project Ho. } \\
\text { PFP FSAR }\end{array}$ & $\begin{array}{l}4 . \text { Page } \\
4 \text { of } 9\end{array}$ \\
\hline
\end{tabular}

\begin{tabular}{|c|c|c|c|c|}
\hline \begin{tabular}{l|}
2. \\
Item
\end{tabular} & $\begin{array}{l}\text { 13. Corment(s)/o iscrepancy(s) (Provide technical justification for the } \\
\text { comment and detai (ed recomentatation of the action required to correct/ } \\
\text { resolve the discrepancy/groblem indicated.) }\end{array}$ & $\begin{array}{l}14 . \\
\text { Hold } \\
\text { point }\end{array}$ & 15. Disposition (Provide justification if NOT accepted.) & $\begin{array}{l}16 . \\
\text { Status }\end{array}$ \\
\hline 14. & SOLID WASTE: (Jim HilTiard is doing review) & & & \\
\hline 15. & $\begin{array}{l}\text { Page } 7-39,7.3 .5, \text { lst Para, , 4th Sentence" CHANGE } \\
\text { to "Low Tevei waste packages may be placed directly } \\
\text { into the waste container after contamination survey } \\
\text { to verify there is no surface contamination." }\end{array}$ & & Accegit & \\
\hline 16. & $\begin{array}{l}\text { Page 7-40, 7.3.5, 3rd Para., CHANGE to "Department } \\
\text { of Transportation shipping regulations limit each } \\
\text { waste package to less than } 20 / \mathrm{dpm} / 100 \mathrm{~cm}^{2} \text { removabie } \\
\text { alpha contamination, however Hanford Site and PFP } \\
\text { radiological control policies prohibit any } \\
\text { detectable removable surface contamination." }\end{array}$ & & Acogit & \\
\hline 17. & $\begin{array}{l}\text { Page } 7-44,7.3 .8 \text {, 2nd Para., 1st bullet, } 4 \text { th dash: } \\
\text { DELETE "and } 280 \mathrm{~kg} \text { of nonfl ammable refrigerant gas." } \\
\text { I had the freon transferred to Hanford Site REM team } \\
\text { a couple of years ago. }\end{array}$ & & $A=$ pt & \\
\hline 18. & $\begin{array}{l}\text { Page T7-8, Tab7e 7-4: ADD "(inactive)" listing } \\
\text { after entries for } H A-4 O F \text { and } H C-46 F \text {. }\end{array}$ & & $A<\operatorname{cop}^{\circ}$ & \\
\hline 19. & $\begin{array}{l}\text { Page T7-10, Table 7-5: ADD "(inactive)" listing } \\
\text { after entries for Tank } 12 / 125 \text {, Tank } 43 \text {, Tank } 21 \text {, and } \\
\text { al1 of Room } 41 \text {. }\end{array}$ & & Accopt & \\
\hline 20. & $\begin{array}{l}\text { Page } 77-12 \text {, Note "b" at bottom of Table: DELETE } \\
\text { "The buitding has been turned over to Bechtel for } \\
\text { D\&D". }\end{array}$ & & Acoupt & \\
\hline 21. & $\begin{array}{l}\text { Page F7-1, Figure 7-1, DELETE: "Primary/Backup" } \\
\text { from flow for both } 2736-Z B \text { and } 2736-Z A \text {. CHANGE } 241- \\
\text { Z/ZA to "Ventilation } 241-Z / Z A \text { waste tanks, vaults } \\
\text { and glovebox". }\end{array}$ & & $\begin{array}{l}\text { Aceopt } \\
\text { Acoget }\end{array}$ & \\
\hline
\end{tabular}
कि? ? 


\begin{tabular}{|c|c|c|}
\hline & 1. Date $12 / 21 / 98$ & $\begin{array}{l}\text { 2. Revies Ho. } \\
\text { jpk. ch7 }\end{array}$ \\
\hline REVIEW COMMENT RECORD (RCR) & $\begin{array}{l}\text { 3. Project No. } \\
\text { PFP FSAR }\end{array}$ & 4. Page \\
\hline
\end{tabular}

\begin{tabular}{|c|c|c|c|c|}
\hline $\begin{array}{l}12 . \\
1 \text { tem }\end{array}$ & $\begin{array}{l}\text { 13. Comment(s)/Discrepancy(s) (Provide technical justification for the } \\
\text { corment and detailed recormendation of the action required to correct/ } \\
\text { resolve the discrepancy/problem indicated.) }\end{array}$ & $\begin{array}{l}14 . \\
\text { Hoid } \\
\text { Point }\end{array}$ & 15. Disposition (Provide justification if NoT accepted.) & $\begin{array}{l}16 . \\
\text { Status }\end{array}$ \\
\hline 22. & $\begin{array}{l}\text { The remaining comments are from Jim Hilliard, } \\
\text { Manager, PFP Solid Waste Operations, and Gary } \\
\text { Backlund, PFP Environmental Engineering. } \\
\text { Page 7-35, } 7.3 .1 \text {, 1st Sentence: CHANGE "stores" to } \\
\text { "manages". }\end{array}$ & & Ac & \\
\hline 23. & $\begin{array}{l}\text { Page } 7-36,7.3 .1,3 \text { rd Bullet: CHANGE "RCRA" to } \\
\text { "RCRA/WAC 173-303" }\end{array}$ & & & \\
\hline 24. & $\begin{array}{l}\text { Page } 7-36,7.3 .1,4 \text { th Bullet: END 1st sentence } \\
\text { after "environment". CHANGE remaining to "Such } \\
\text { wastes are } 7 \text { isted and defined in WAC 173-303 as } \\
\text { discarded chemical projects or dangerous wastes } \\
\text { sources. }\end{array}$ & & $\begin{array}{l}A<c \\
A<c\end{array}$ & \\
\hline 25. & Page $7-36,7.3 .1$, 2nd Para.: Delete "Note" at end. & & $A$ cosp & \\
\hline 26. & $\begin{array}{l}\text { Page 7-36, 7.3.1.1: ADD "and HNF-EP-OO63" after } \\
\text { "HNF-PRO-45.5". 2nd Bullet: CHANGE "Combination" to } \\
\text { "Segregation". 4th Bullet: CHANGE to "Prohibition } \\
\text { of disposal of nonradioactive wastes in containers } \\
\text { specifically marked for radioactive materials" 5th } \\
\text { BuTlet: CHANGE to "Prohibition of explosives or } \\
\text { pyrophorics in wastes". DELETE existing 7th and 8th } \\
\text { Bullets. }\end{array}$ & & Accest & \\
\hline 27: & $\begin{array}{l}\text { Page } 7-37,7.3 .1 .3: \text { ADD "and HNF-EP-0063" after } \\
\text { "HNF-PRO-455". }\end{array}$ & & & \\
\hline
\end{tabular}




\begin{tabular}{|c|c|c|}
\hline \multirow{2}{*}{ REVIEW COMMENT RECORD (RCR) } & $\begin{array}{l}\text { 1. Date } \\
12 / 21 / 98 \\
\end{array}$ & $\begin{array}{l}\text { 2. Review No. } \\
\text { jpk.ch7 }\end{array}$ \\
\hline & $\begin{array}{l}\text { 3. Project No. } \\
\text { PFP FSAR }\end{array}$ & 4. Page \\
\hline
\end{tabular}

\begin{tabular}{|c|c|c|c|c|}
\hline $\begin{array}{l}12 . \\
\text { Item }\end{array}$ & $\begin{array}{l}\text { 13. Corment(s)/Discrepancy(s) (Provide technical justification for the } \\
\text { comment and detailed recomendiat ion of the action required to correct/ } \\
\text { resolve the discrepancy/problem indicated.) }\end{array}$ & $\begin{array}{l}14 . \\
\text { Moid } \\
\text { Point }\end{array}$ & 15. Disposition (Provide justification if NOT accepted.) & $\begin{array}{l}\text { 16. } \\
\text { Status }\end{array}$ \\
\hline 28. & $\begin{array}{l}\text { Page 7-37 \& 7-38, 7.3.4: DELETE ALL AND REPLACE } \\
\text { WITH "So]jd wastes generated at the PFP are packaged } \\
\text { and shipped to the appropriate } \\
\text { Treatment/Storage/Disposal (TSD) facilities in } \\
\text { accordance with site and facility policies and } \\
\text { procedures. The PFP interfaces with Waste } \\
\text { Management of Hanford (WMH) to ensure all waste } \\
\text { characterization, packaging, and transportation } \\
\text { requirements are met for each waste container. } \\
\text { If possib]e, waste management activities are planned } \\
\text { in advance and are included in the pre-planning } \\
\text { stages of work being performed at the facility. WMH } \\
\text { personnel are assigned to assist the PFP personnel } \\
\text { meet federal, state, and site requirements and } \\
\text { policies regarding waste characterization, } \\
\text { packaging, and transportation. } \\
\text { The generated waste is characterized and determined } \\
\text { to meet a specific Waste Specification Record } \\
\text { (WSRd). WMH personnel develop a waste profile which } \\
\text { describes the waste stream, characteristics, and } \\
\text { packaging. WMH personnel also develop a portfolio } \\
\text { which inciudes characterization documents (i.e. } \\
\text { sample analysis, inventory sheets, MSDSs, etc.) as } \\
\text { well as appropriate shipping documentation. The } \\
\text { portfolio is sent to the receiving TSD facility for } \\
\text { approval. When the portfolio has been approved the } \\
\text { waste is shipped to the appropriate TSD per } 49 \text { cFR } \\
\text { (DoT) or the applicable SARP/SEP. } \\
\text { [continued next page] }\end{array}$ & & Acespt & \\
\hline
\end{tabular}




\begin{tabular}{|c|c|c|}
\hline & $\begin{array}{r}\text { 1. Date } \\
12 / 21 / 98 \\
\end{array}$ & $\begin{array}{r}\text { 2. Review Ho. } \\
\text { jpk.ch7 }\end{array}$ \\
\hline REVIEW COMMENI $\mathrm{R}$ & $\begin{array}{l}\text { 3. Project No. } \\
\text { PFP FSAR }\end{array}$ & 4. Page \\
\hline
\end{tabular}

12. 13. Comment(s)/Discrepancy(s) (Provide technical justification for the

item coment and detailed recomendation of the action required to for the cesolve the discrepancy/problem indicated.)

[rewrite of 7.3 .4 continued]

The WMH managed TSD facilities perform waste verification on the waste containers to ensure the waste complies with the waste profile. Waste verification varies between $5 \%$ and $100 \%$ on waste containers depending on the waste stream and waste nonconformances.

29. Page 7-38, 7.3.4.2, 2nd Para., 3rd Sentence: DELETE "3-L of diatomaceous earth". CHANGE "and 3-1 of diatomaceous earth" to "and absorbent". 3rd Para., 3rd Sentence: INSERT "(minimum)" between "6-mj]"

to and "polyethylene". 4th Sentence: END sentence

$=\quad$ after "use". DELETE "with security seals used to prevent unauthorized waste additions".

30. Page 7-39, 7.3.5, Ist Para., Ist Sentence: INSERT "generally" between "is" and "sealed". 2nd

sentence: DELETE "to the 234-5Z Building, room 234$A, "$ and DELETE "by the NaI package counter". DELETE existing 5th Sentence. 6th Sentence: CHANGE "200 $\mathrm{g}$ " to "187 g". Ist Bullet: CHANGE "200 g" to "187 g", CHANGE "WIPP" to "HNF-EP-0063". 3rd Bullet: CHANGE "WIPP" to "HNF-EP-0063". 5th Bullet: DELETE as written, REPLACE with "When the drum is physicaliy full and additional waste can not be added".

31. Page 7-39, 7.3.5, 2nd Para., 1st Bullet: CHANGE "standard DOT" to "CAUTION". 3ra Builet: CHANGE "200 g" to "187 g".

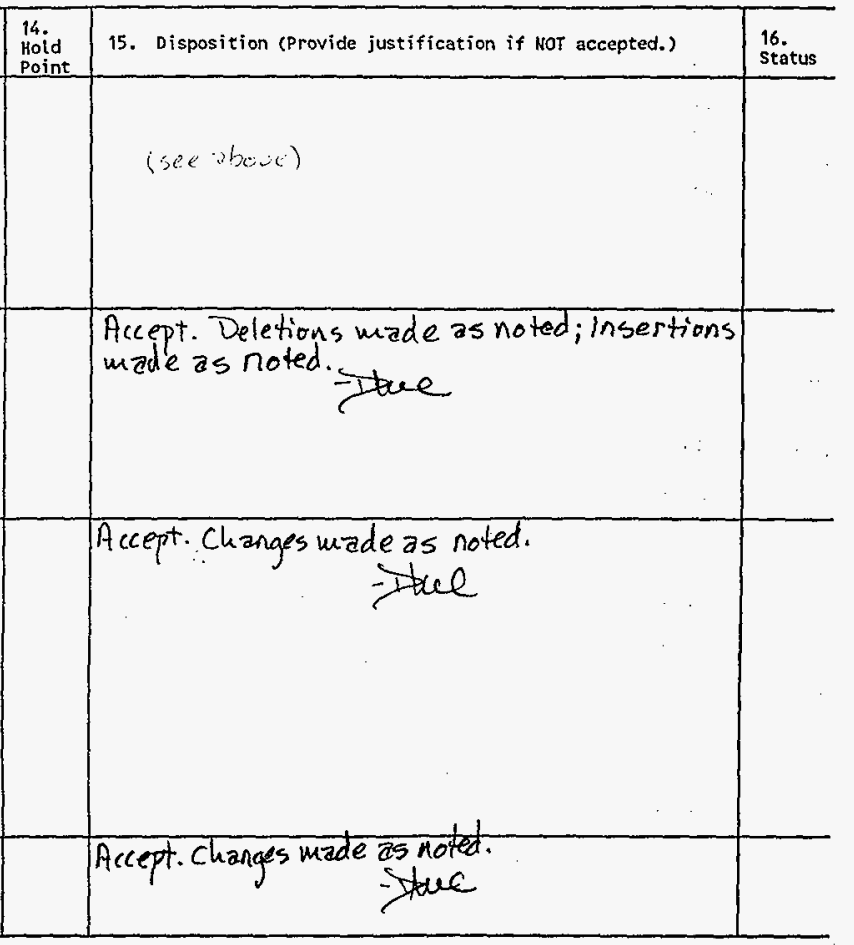




\begin{tabular}{|l|l|l|l|l|}
\hline REVIEW COMMENT RECORD (RCR) & $\begin{array}{l}1 . \text { Date Review No. } \\
\text { jpk.ch7 }\end{array}$ \\
\hline $\begin{array}{l}3 . \text { Project Ho. } \\
\text { PFP FSAR }\end{array}$ & 4. Page \\
\hline
\end{tabular}

12. 13. Comment(s)/Discrepancy(s) (Provide technical justification for the Item coment and detailed recomendation of the action required to correct/ resolve the discrepancy/problem indicated.)

32. Page 7-40, 7.3.5, 4th Para., 5th Sentence: DELETE "where category i is equal to or less than $10 \mathrm{nCi} / \mathrm{g}$ and category 3 is greater than $10 \mathrm{nCi} / \mathrm{g}$ and $1 \mathrm{ess}$ than $100 \mathrm{nCi} / \mathrm{g}$ " REPLACE with "based upon HNF-EP$0063^{\prime \prime}$. 5th Para., 2nd Sentence: DELETE "an RCT after it is surveyed" REPLACE with "surface contamination Tevels or NDA".

33. Page 7-40, 7.3.5 6th Para.: DELETE entire paragraph and bullets. REPLACE with "TRU drums are vented using a carbon composite filter in the Tid of the drum. If a waste drum is determined to be pressurized, it is depressurized using a specific work plan." 7th Para., 3rd Sentence: DELETE

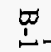
"(diatomaceous earth)". 8th Para., DELETE entirely.

34. Page 7-41, 7.3.5, 9th Para., DELETE entire paragraph and REPLACE with, "MWs are packaged to meet HNF-EP-0063, 49 CFR, and/or SARPS, and the appropriate waste profile in accordance with facility specific procedures or workplans. MWs are stored in designated hazardous waste 90-day accumulation areas prior to shipment to the appropriate treatment, storage, or disposal facility (TSD).

35. Page 7-41, 7.3.5.1, Ist Para., 1st Bullet, 1st dash: CHANGE "200 g" to "187 g". 2nd Para., CHANGE "burial boxes" to "standard waste boxes (SWBS)". 2nd Para., ist Bullet: CHANGE "350 g" to "325 g", Change "Standard Waste Box" to "SWB". 2nd Bullet: CHANGE "burial box" to "SWB". 3rd Para., 1st Bullet:, 3rd Sentence: CHANGE "diatomaceous earth" to "absorbent". 


\begin{tabular}{|c|c|c|}
\hline \multirow{2}{*}{ REVIEW COMMENT RECORD (RCR) } & 1. Date $12 / 21 / 98$ & $\begin{array}{l}\text { 2. Review No. } \\
\text { jpk.ch7 }\end{array}$ \\
\hline & $\begin{array}{l}\text { 3. Project No. } \\
\text { PFP FSAR }\end{array}$ & 9 of 9 \\
\hline
\end{tabular}

\begin{tabular}{|c|c|c|c|c|}
\hline $\begin{array}{l}12 . \\
\text { Item }\end{array}$ & $\begin{array}{l}\text { 13. Comment( }(s) / 0 \text { iscrepancy(s) (Provide technical justification for the } \\
\text { comment and detailed recomendation of the action required to correct/ } \\
\text { resolve the diserepancy/problem indicated.) }\end{array}$ & $\begin{array}{l}14 . \\
\text { Hoid } \\
\text { Point }\end{array}$ & 15. Disposition (Provide justification if NOT accepted.) & $\begin{array}{l}\text { 16. } \\
\text { Status }\end{array}$ \\
\hline 36. & $\begin{array}{l}\text { Page 7-42, 7.3.5.1, 3rd Para., 3rd Bullet: DELETE } \\
\text { entirely. Existing 4th BuTlet: INSERT "TRU" } \\
\text { between "The" and "HEPA". INSERT "Or SWBs" between } \\
\text { "drums" and "marked". INSERT "or SWBs" between } \\
\text { "drums" and "used". }\end{array}$ & & Accept. Changesurade asnoted. & \\
\hline 37 & $\begin{array}{l}\text { Page } 7-42,7.3 .6 .1: \text { DELETE entire paragraph and } \\
\text { bullets. } 7.3 .6 .2: \text { DELETE entire paragraph } \\
\text { including that on Page } 7-43 \text {. }\end{array}$ & & Accept: Deleted. & \\
\hline 38 . & $\begin{array}{l}\text { Page } 7-43,7.3 .7 \text { (needs renumbered } 7.3 .6 \text { ), Ist } \\
\text { Para., 2nd Sentence: INSERT "packaging" between } \\
\text { "The" and "requirements". ADD ", specific } \\
\text { SARPS/SEPS, and/or } 49 \text { CFR" after "HNF-EP-0063". 3rd } \\
\text { Para., DELETE entirely. }\end{array}$ & & $\begin{array}{l}\text { Accept. Changes made as uoted ExcEPT: sectiop } \\
\text { not renumbered; previous section was not entirely } \\
\text { deleted. Stuel }\end{array}$ & \\
\hline$\quad$ & $\begin{array}{l}\text { Page 7-44, 7.3.8 (needs renumbered to } 7.3 .7 \text { ): } \\
\text { OELETE entire existing section, REPLACE with } \\
\text { "Containerized LLW is stored either in radioactive } \\
\text { material areas (RMAs) within the } 234-5 Z \text { or } 2736-2 B \\
\text { buildings or outside in the } 234-5 Z \text { West Pad or South } \\
\text { Pad waste storage RMAs. } \\
\text { Containerized TRU waste may be stored in the same } \\
\text { locations. When TRU waste is stored in an outside } \\
\text { RMA it must meet the requirements of WHC-SD-CP-OSR- } \\
\text { 010, } 5.24 .1 \text { "management of TRU material stored in } \\
\text { RMA outside facility buildings". } \\
\text { MW and DW must be stored in established satellite } \\
\text { accumulation areas (SAAs). When a SAA accumulates } \\
55 \text { gallons of DW/MW or } 1 \text { quart of acutely hazardous } \\
\text { waste it must be moved to the appropriate } 90 \text { day } \\
\text { accumulation area within three days. 90 day } \\
\text { accumulation areas are inspected on a weekly basis } \\
\text { per WAC I73-303." }\end{array}$ & & $\begin{array}{c}\text { Accept. Incorporation as noted. } \\
\text { Ifuce. }\end{array}$ & \\
\hline
\end{tabular}


HNF-4029 Rev. 0

Johnson, LE (Safety Analysis)

From:

Sent:

To:

Subject:
King, Jeffry $P$ (Jeff)

Monday, December 21, 1998 6:43 PM

Johnson, LE (Safety Analysis); Ramble, Alan L; Hilliard, James R (Jim); Backlund, Ernest .G (Gary)

Attached in WP 5.1 file. Jim, Gary: Thanks for the quick turn-around on the review. Please check over and make sure I accurately captured your comments.

Jeff

Ki. Hiring

Backlont.

$k^{d / t}$

Beth copies of RCR

used for diange-sidecumantation.

- tee 25 Dec 98

B-116 


\section{REVIEW COMMENT RECORD (RCR)}

\begin{tabular}{|l|l|}
\hline $\begin{array}{c}\text { 1. Date } \\
12 / 21 / 98\end{array}$ & $\begin{array}{l}\text { 2. Review No. } \\
\text { jpk.ch7 }\end{array}$ \\
\hline $\begin{array}{c}\text { 3. Project Ho. } \\
\text { PFP FSAR }\end{array}$ & 4. Page \\
\hline
\end{tabular}

\section{Document Number(s)/Title(s)}

WHC-SD-CP-SAR-021 Draft Rev. 1 Plutonium Finishing Plant Final Safety Analysis Report Chapter 7

17. Comment Submittal Approval:

Organization Manager (Optional)

\begin{tabular}{l|l}
$\begin{array}{l}\text { 6. Program/Project/ } \\
\text { Building Number }\end{array}$ & 7. Reviewer \\
PFP & J.P. King \\
$\begin{array}{l}\text { Authorization } \\
\text { Basis }\end{array}$ &
\end{tabular}

10. Agreement with indicated comment disposition(s)

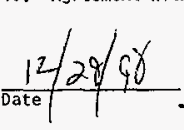

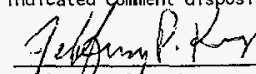

Reliewer/Point of Contact

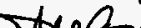

Author/originator

9. Location/Phone

$270-Z / 373-5194$

\begin{tabular}{|c|c|c|c|c|}
\hline $\begin{array}{l}12 . \\
\text { item }\end{array}$ & $\begin{array}{l}\text { 13. Comment(s)/Discrepancy(s) (Provide technical justification for the } \\
\text { comment and detailed recommendat ion of the action required to correct/ } \\
\text { resolve the discrepancy/problem indicated.) }\end{array}$ & $\begin{array}{l}14 . \\
\text { Hold } \\
\text { Point }\end{array}$ & 15. Disposition (Provide justification if NOT accepted.) & $\begin{array}{l}16 . \\
\text { Status }\end{array}$ \\
\hline 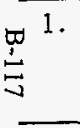 & $\begin{array}{l}\text { Page 7-iij PREFACE, 1st Para.: ADD another item for } \\
\text { Revision; "Sanitary Sewer System to reflect the } \\
\text { change from the PFP sanitary drain tile field to the } \\
\text { 200-West Area Regional Drainfield." }\end{array}$ & & Accept. Added ite & \\
\hline 2. & $\begin{array}{l}\text { Page 7-iii, PREFACE, 2nd Para., 5th Sentence: } \\
\text { DELETE "operation and" from sentence. } \\
\text { White the essential function of the electrically } \\
\text { driven fans remains the same as for steam turbines, } \\
\text { their operation is significant7y different. }\end{array}$ & & $\begin{array}{l}\text { Sontance detet } \\
\text { reviewrer's com }\end{array}$ & \\
\hline 3. & $\begin{array}{l}\text { Page } 7-9,7.1 .2 \text { 3rd Para, 4th Sentence: END } \\
\text { SENTENCE AFTER "radioactive material". DELETE "and } \\
\text { have been isolated from the ventilation system". } \\
232-Z \text { hoods and gloveboxes are still very much } \\
\text { connected (not isolated) from the ventilation } \\
\text { system. }\end{array}$ & & Accept. Del & \\
\hline
\end{tabular}




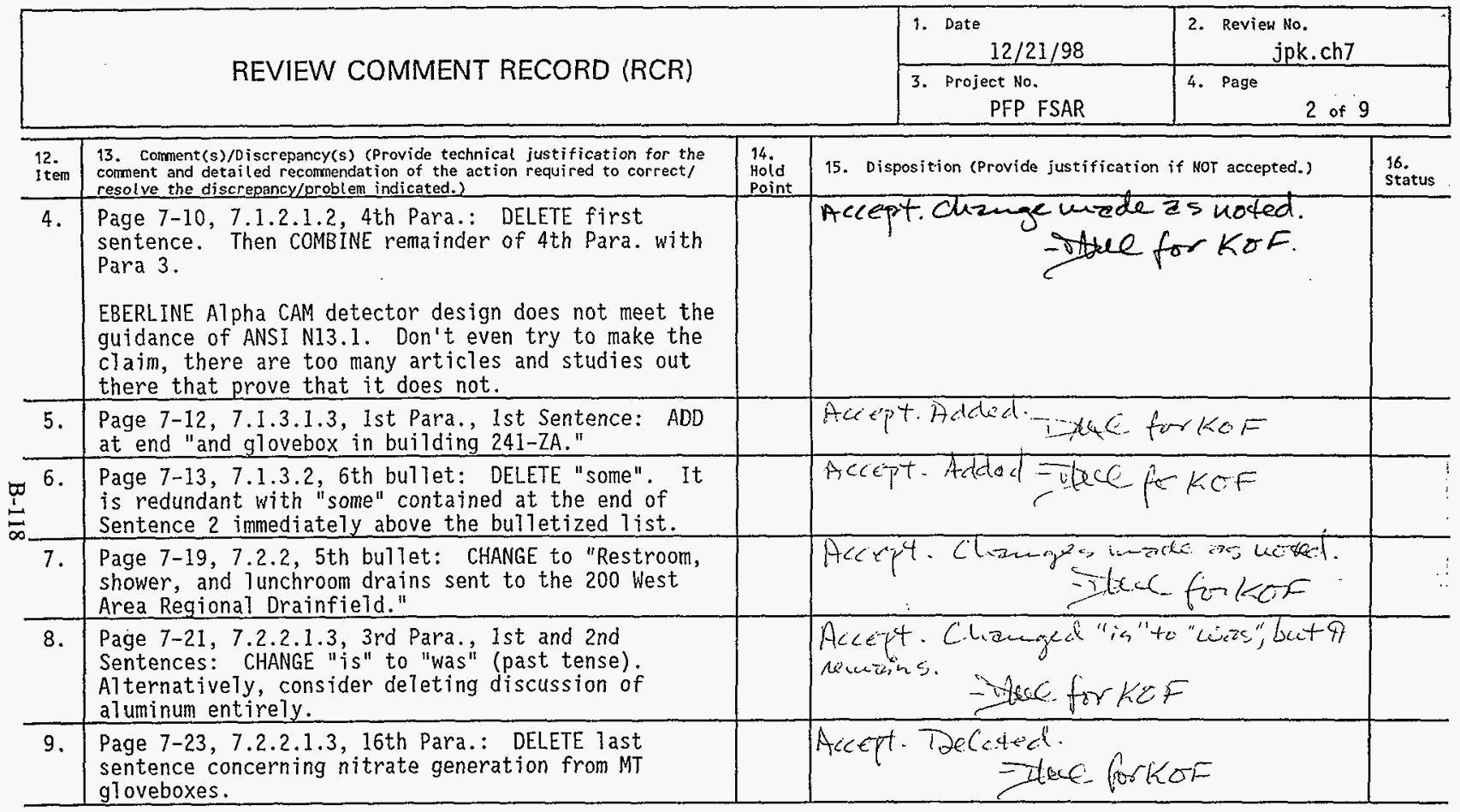




\begin{tabular}{|c|c|c|c|}
\hline \multirow{2}{*}{ REVIEW COMMENT RECORD (RCR) } & \multirow{2}{*}{ 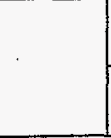 } & $\begin{array}{l}\text { 1. Date } \\
12 / 21 / 98 \\
\end{array}$ & $\begin{array}{l}\text { 2. Review No. } \\
\text { jpk.ch7 }\end{array}$ \\
\hline & & $\begin{array}{l}\text { 3. Project No. } \\
\text { PFP FSAR }\end{array}$ & 4. Page 3 of 9 \\
\hline
\end{tabular}

\begin{tabular}{|c|c|c|c|c|}
\hline $\begin{array}{l}12 . \\
\text { Item }\end{array}$ & $\begin{array}{l}\text { 13. Comment(s)/Discrepancy(s) (Provide technical justification for the } \\
\text { comment and detaited recomendation of the action required to correct/ } \\
\text { resolve the discrepancy/problem, indicated.) }\end{array}$ & $\begin{array}{l}14 . \\
\text { Hold } \\
\text { Point }\end{array}$ & 15. Disposition (Provide justification if NOT accepted.) & $\begin{array}{l}16 . \\
\text { Status }\end{array}$ \\
\hline 10 & $\begin{array}{l}\text { Page } 7-27,7.2 .2 .4 .1 \text { 2nd Sentence: CHANGE to "These } \\
\text { sanitary sewer systems take receive Tiquid from } \\
\text { restrooms, showers, and lunchroom sinks and dispose } \\
\text { of it through septic tanks, pump stations, and to } \\
\text { the } 2607-W 1 \text { regional drainfield located } \\
\text { approximately one half mile away, where it is } \\
\text { percolated into the soil." } \\
\text { This project is being completed as part of project } \\
\text { L-281. }\end{array}$ & & 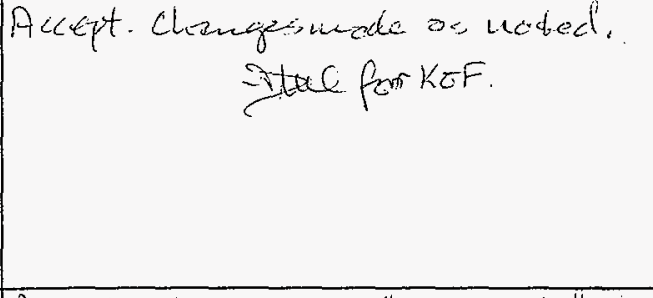 & \\
\hline 11. & $\begin{array}{l}\text { Page } 7-28,7.2 .2 .5 \text { This Paragraph needs to be sp] it } \\
\text { into two, one for PRF Room } 40 \text {, one for } 234-5 Z \text { Rooms } \\
336 / 337 \text {. For PRF Room } 40: \text { A17 PRF processes are } \\
\text { currently inactive and not authorized for operation. } \\
\text { Chemicals remaining in the PRF tanks and process } \\
7 \text { ines will be managed and dispositioned in } \\
\text { accordance with HNF-2977, "PTutonium Reclamation } \\
\text { Facility (PRF, Building } 236-Z \text { ) Layup Plan" BWHC, } \\
1998 \text {. Electrical to instrumentation in the room has } \\
\text { been isolated. } \\
\text { 234-5Z Rooms } 2336 / 337 \text { contain three active chemical } \\
\text { tanks that will be required to support future } \\
\text { material stabilization activities. }\end{array}$ & & 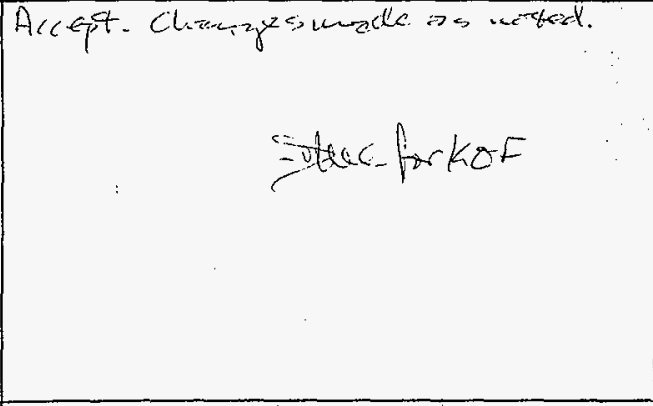 & \\
\hline 12. & $\begin{array}{l}\text { Page 7-30, 7.2.3.1.1, 3rd Para., lst Sentence: } \\
\text { CHANGE "building" to "facility". } \\
\text { 244-TX is an underground storage vault with } \\
\text { associated instrumentation building and exhaust } \\
\text { system. "facility" is a more accurate description. }\end{array}$ & & Accept. Cliameg & \\
\hline 13. & $\begin{array}{l}\text { Page 7-31, 7.2.3.2.1, 1st Para., 2nd Sentence: } \\
\text { DELETE "drinking water". It is redundant with } \\
\text { "sanjtary water". }\end{array}$ & & Acceft. PEesti: $=$ & \\
\hline
\end{tabular}




\begin{tabular}{|c|c|c|}
\hline & $\begin{array}{l}\text { 1. Date } \\
12 / 21 / 98 \\
\end{array}$ & $\begin{array}{l}\text { 2. Review No. } \\
\text { jpk.ch7 }\end{array}$ \\
\hline REVIEW COMMENT RECORD (RCR) & $\begin{array}{l}\text { 3. Project No. } \\
\text { PFP FSAR }\end{array}$ & 4. Page \\
\hline
\end{tabular}

\begin{tabular}{|c|c|c|c|c|}
\hline $\begin{array}{l}2 . \\
\text { 1 tem }\end{array}$ & $\begin{array}{l}\text { 33. Comment(s)/oiscrepancys(s) (Provide technical just ification for the } \\
\text { comment and detailed recormendation of the action required to correct/ } \\
\text { resolve the discrepancy/problem indicated.) }\end{array}$ & $\begin{array}{l}14 . \\
\text { Hold } \\
\text { Point }\end{array}$ & 15. Disposition (Provide justification if NOT accepted.) & $\begin{array}{l}16 . \\
\text { status } \\
\end{array}$ \\
\hline 14. & SOLID WASTE: (Jim Hilitiard is doing review) & & 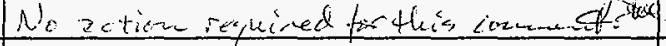 & - \\
\hline 15. & $\begin{array}{l}\text { Page } 7-39,7.3 .5, \text { lst Para., } 4 \text { th Sentence" CHANGE } \\
\text { to "Low Teve } 1 \text { waste packages may be placed directly } \\
\text { into the waste container after contamination survey } \\
\text { to verify there is no surface contamination." }\end{array}$ & & Accept. Added stece forkef & \\
\hline 16. & $\begin{array}{l}\text { Page } 7-40,7.3 .5,3 \text { rd Para., CHANGE to "Department } \\
\text { of Transportation shipping regulations limit each } \\
\text { waste package to less than } 20 / \mathrm{dpm} / 100 \mathrm{~cm}^{2} \text { removable } \\
\text { alpha contamination, however Hanford Site and PFP } \\
\text { radiological control policies prohibit any } \\
\text { detectable removable surface contamination." }\end{array}$ & & Accept. Clinempor & \\
\hline 17. & $\begin{array}{l}\text { Page } 7-44,7.3 .8 \text {, 2nd Para., lst bullet, 4th dash: } \\
\text { DELETE "and } 280 \mathrm{~kg} \text { of nonflammable refrigerant gas." } \\
\text { I had the freon transferred to Hanford site REM team } \\
\text { a couple of years ago. }\end{array}$ & & $\begin{array}{c}\text { Entive section repleced dacto } \\
\text { ancether reviewer's conmest. } \\
\text {-vlece }\end{array}$ & \\
\hline 18. & $\begin{array}{l}\text { Page T7-8, Table 7-4: ADD "(inactive)" listing } \\
\text { after entries for } \mathrm{HA}-40 \mathrm{~F} \text { and } \mathrm{HC}-46 \mathrm{~F} \text {. }\end{array}$ & & Accept. Added sevel for koF & \\
\hline 19. & $\begin{array}{l}\text { Page T7-10, Table 7-5: ADD "(inactive)" listing } \\
\text { after entries for Tank 12/125, Tank 43, Tank } 21 \text {, and } \\
\text { a11 of Room } 41 \text {. }\end{array}$ & & Accept. Added. & \\
\hline 20. & $\begin{array}{l}\text { Page T7-12, Note "b" at bottom of Table: DELETE } \\
\text { "The building has been turned over to Bechtel for } \\
\text { D\&D". }\end{array}$ & & 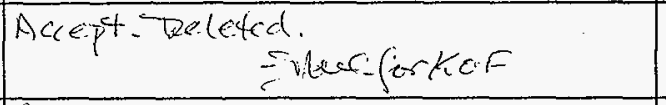 & \\
\hline 21. & $\begin{array}{l}\text { Page F7-1, Figure 7-1, DELETE: "Primary/Backup" } \\
\text { from flow for both } 2736-Z B \text { and } 2736-Z A \text {. CHANGE } 241- \\
\text { Z/ZA to "Venti7ation } 241-Z / Z A \text { waste tanks, vaults } \\
\text { and glovebox". }\end{array}$ & & 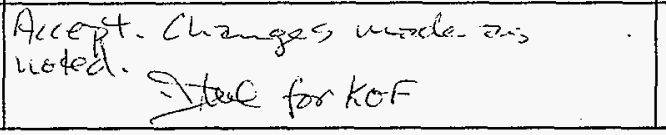 & \\
\hline
\end{tabular}




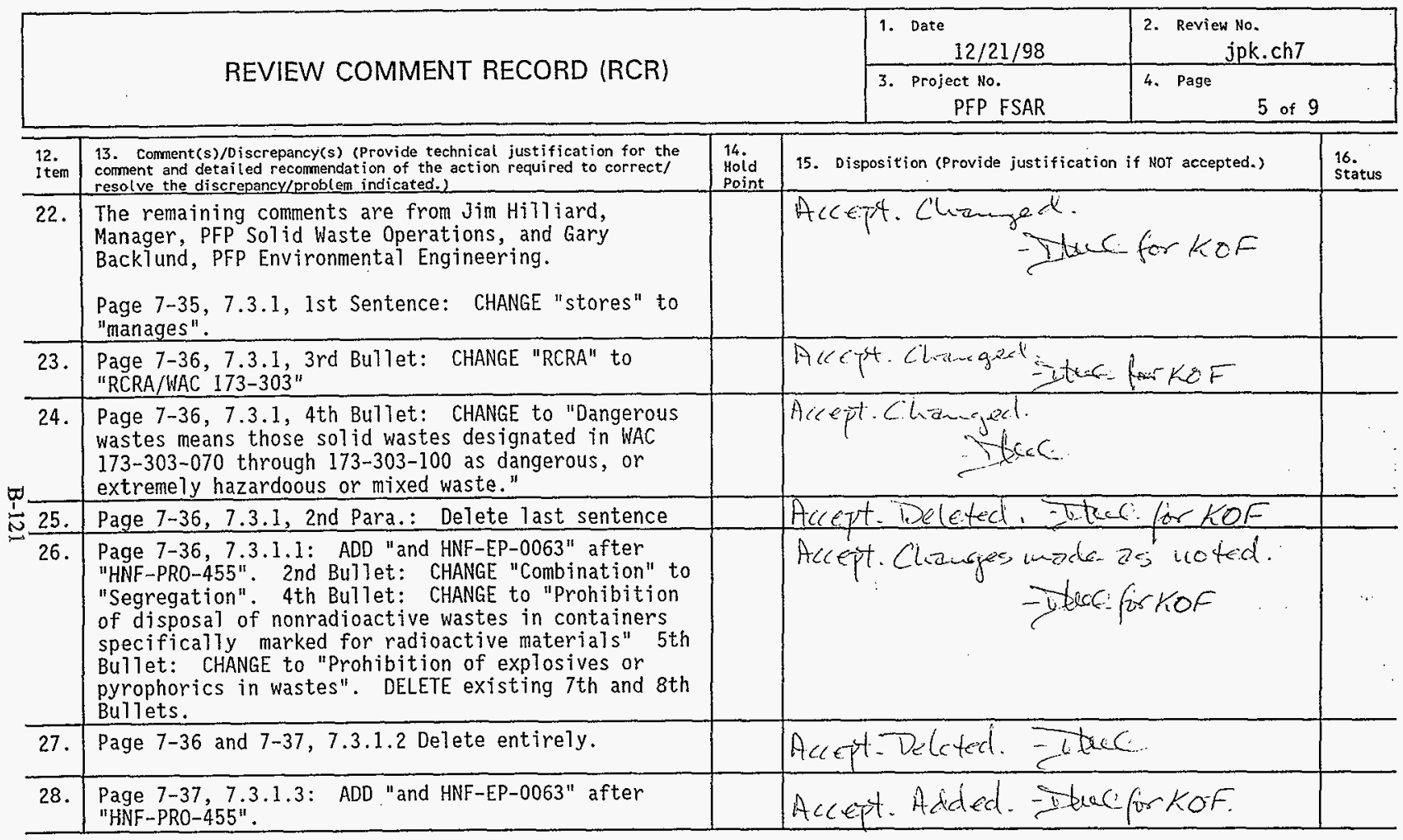




\begin{tabular}{|c|c|c|c|}
\hline \multirow{2}{*}{ REVIEW COMMENT RECORD (RCR) } & $\begin{array}{l}\text { 2. Date Review No. } \\
\text { jpk. ch7 }\end{array}$ & $\begin{array}{c}12 / 21 / 98 \\
\text { 3. Project No. } \\
\text { PFP FSAR }\end{array}$ & $\begin{array}{c}4 . \text { Page } \\
6 \text { of } 9\end{array}$ \\
\hline
\end{tabular}

\begin{tabular}{|c|c|c|c|c|}
\hline $\begin{array}{l}12 . \\
\text { I tem }\end{array}$ & $\begin{array}{l}\text { 13. Comment( } \$) / 0 \text { iscrepancy(s) (Provide technjicat justification for the } \\
\text { comment and detai led recommendation of the action required to correct/ } \\
\text { resolve the discrepancy/problem indicated.) }\end{array}$ & $\begin{array}{l}14 . \\
\text { Hold } \\
\text { Point }\end{array}$ & 15. Disposition (Provide justification if Nor accepted.) & $\begin{array}{l}16 . \\
\text { status }\end{array}$ \\
\hline 29. & $\begin{array}{l}\text { Page } 7-37 \text { \& } 7-38,7.3 .4: \text { DELETE ALL AND REPLACE } \\
\text { WITH "Solid wastes generated at the PFP are packaged } \\
\text { and shipped to the appropriate } \\
\text { Treatment/Storage/Disposal (TSD) facilities in } \\
\text { accordance with site and facility policies and } \\
\text { procedures. The PFP interfaces with Waste } \\
\text { Management of Hanford (WMH) to ensure all waste } \\
\text { characterization, packaging, and transportation } \\
\text { requirements are met for each waste container. } \\
\text { If possible, waste management activities are planned } \\
\text { in advance and are included in the pre-planning } \\
\text { stages of work being performed at the facility. WMH } \\
\text { personnel are assigned to assist the PFP personne? } \\
\text { meet federal, state, and site requirements and } \\
\text { policies regarding waste characterization, } \\
\text { packaging, and transportation. } \\
\text { The generated waste is characterized and determined } \\
\text { to meet a specific Waste Specification Record } \\
\text { (WSRd). WMH personne] develop a waste profile which } \\
\text { describes the waste stream, characteristics, and } \\
\text { packaging. WMH personnel also develop a portfolio } \\
\text { which inciudes characterization documents (i.e. } \\
\text { sample analysis, inventory sheets, MSDSs, etc.) as } \\
\text { well as appropriate shipping documentation. The } \\
\text { portfolio is sent to the receiving TSD facility for } \\
\text { approval. When the portfolio has been approved the } \\
\text { waste is shipped to the appropriate TSD per } 49 \text { CFR } \\
\text { (DoT) or the applicable SARP/SEP. } \\
\text { [continued next page] }\end{array}$ & & 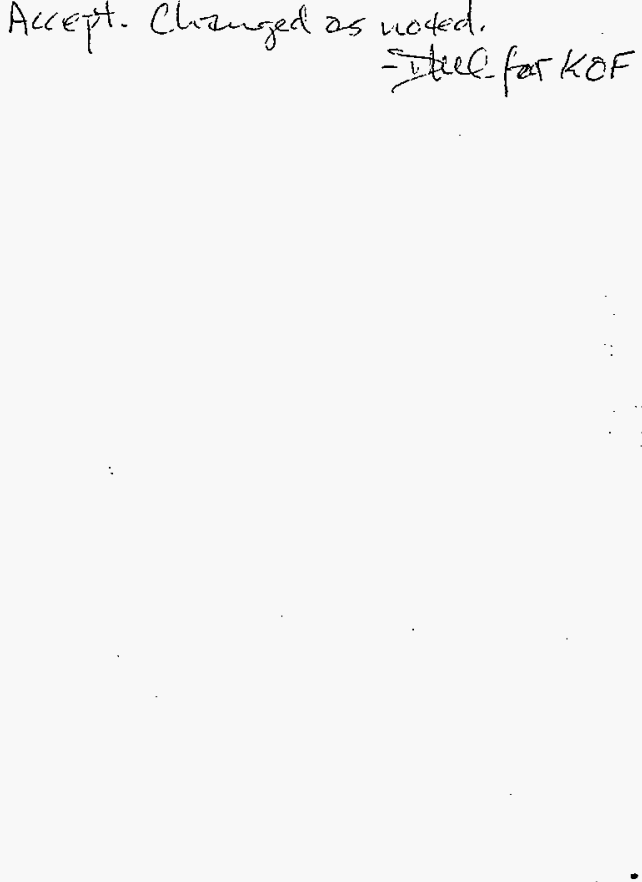 & 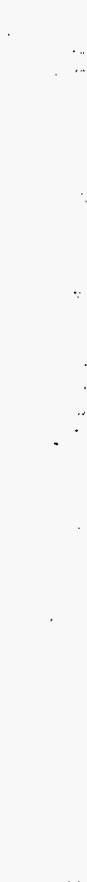 \\
\hline
\end{tabular}




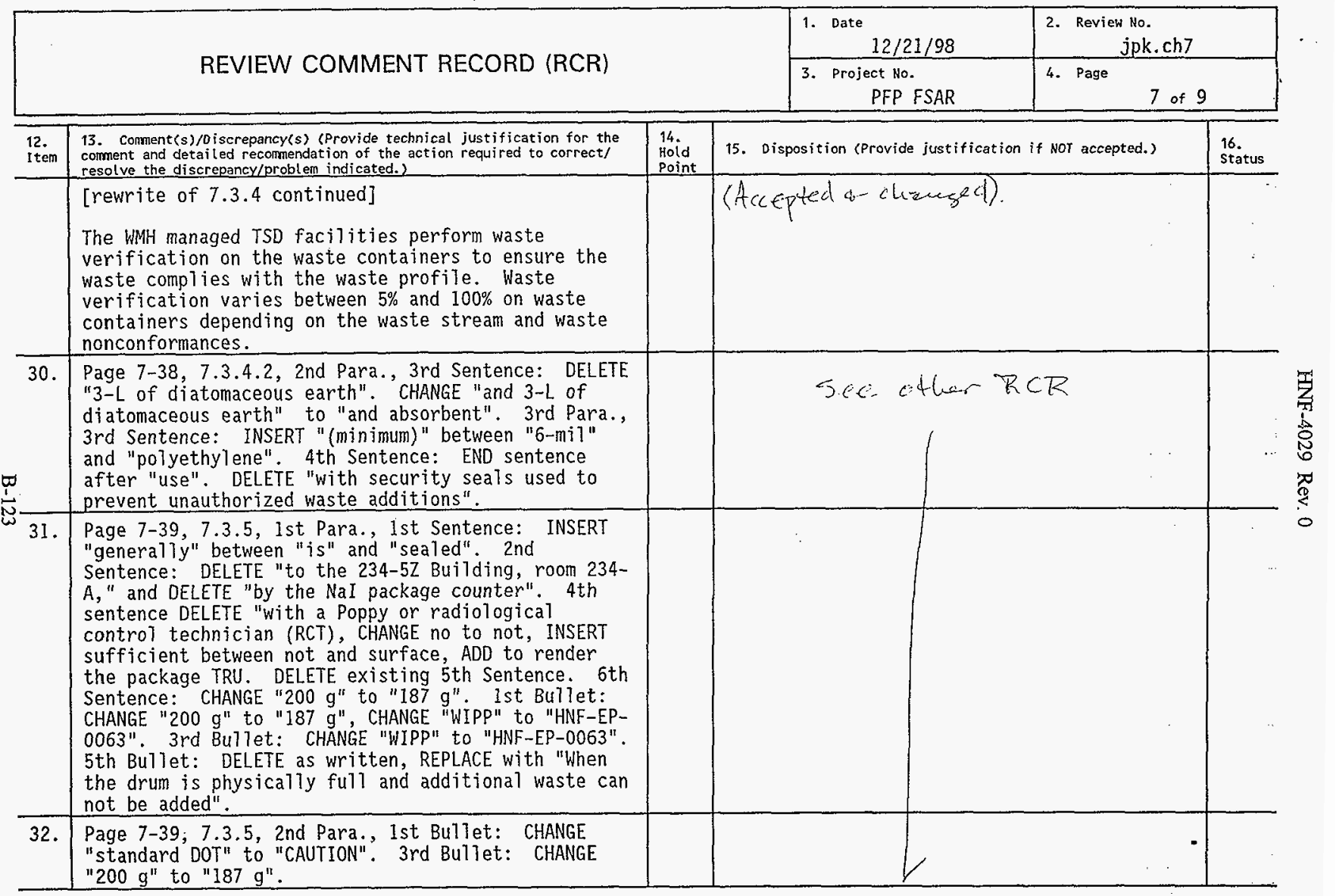




\section{REVIEW COMMENT RECORD (RCR)}

\begin{tabular}{|c|l|}
\hline $\begin{array}{c}\text { 1. Date } \\
12 / 21 / 98\end{array}$ & $\begin{array}{l}\text { 2. Review No. } \\
\text { jpk.ch7 }\end{array}$ \\
\hline $\begin{array}{c}\text { 3. Project No. } \\
\text { PFP FSAR }\end{array}$ & 4. Page 8 of 9 \\
\hline
\end{tabular}

\begin{tabular}{|c|c|c|c|c|}
\hline $\begin{array}{l}12 . \\
\text { I tem }\end{array}$ & $\begin{array}{l}\text { 13. Corment(s)/Discrepancy(s) (Provide technical justification for the } \\
\text { corment and detailed recormendation of the action required to correct/ } \\
\text { resolve the discrepancy/problem indicated.) }\end{array}$ & $\begin{array}{l}\text { Th. } \\
\text { Hold } \\
\text { Point }\end{array}$ & 15. Disposition (Provide justification if NOT accepted.) & $\begin{array}{l}16 . \\
\text { status }\end{array}$ \\
\hline 33. & $\begin{array}{l}\text { Page } 7-40,7.3 .5,4 \text { th Para., } 5 \text { th Sentence: DELETE } \\
\text { "where category } 1 \text { is equal to or less than } 10 \mathrm{nCi} / \mathrm{g} \\
\text { and category } 3 \text { is greater than } 10 \mathrm{nCj} / \mathrm{g} \text { and less } \\
\text { than } 100 \mathrm{nC} / \mathrm{g} \text { " REPLACE with "based upon HNF-EP- } \\
0063 \text { ". 5th Para., 2nd Sentence: DELETE "an RCT } \\
\text { after it is surveyed" REPLACE with "surface } \\
\text { contamination levels or NDA". }\end{array}$ & & $\begin{array}{c}\text { Se exther TRCE } \\
1\end{array}$ & \\
\hline 34. & $\begin{array}{l}\text { Page 7-40, } 7.3 .5 \text { 6th Para.: DELETE entire paragraph } \\
\text { and bullets. REPLACE with "TRU drums are vented } \\
\text { using a carbon composite filter in the lid of the } \\
\text { drum. If a waste drum is determined to be } \\
\text { pressurized, it is depressurized using a specific } \\
\text { work plan." 7th Para., 3rd Sentence: DELETE } \\
\text { "(diatomaceous earth)". 8th Para., DELETE entirely. }\end{array}$ & & & \\
\hline 35 & $\begin{array}{l}\text { Page } 7-41,7.3 .5,9 \text { th Para., DELETE entire } \\
\text { paragraph and REPLACE with, "MWS are packaged to } \\
\text { meet HNF-EP-0063, } 49 \text { CFR, and/or SARPS, and the } \\
\text { appropriate waste profile in accordance with } \\
\text { facility specific procedures or workplans. MWs are } \\
\text { stored in designated hazardous waste } 90 \text {-day } \\
\text { accumulation areas prior to shipment to the } \\
\text { appropriate treatment, storage, or disposal facility } \\
\text { (TSD). }\end{array}$ & & ' & $\begin{array}{l}\ddots \\
.\end{array}$ \\
\hline 36. & $\begin{array}{l}\text { Page 7-41,7.3.5.1, lst Para., Ist Bullet, lst dash: } \\
\text { CHANGE "200 g" to "187 g". 2nd Para., CHANGE } \\
\text { "burial boxes" to "standard Waste boxes (SWBS)". } \\
\text { 2nd Para., lst Bullet: CHANGE " } 350 \mathrm{~g} \text { " to "325 g", } \\
\text { Change "Standard Waste Box" to "SWB". 2nd Bullet: } \\
\text { CHANGE "burial box" to "SWB". 3rd Para., 1st } \\
\text { BuTlet:, 3rd Sentence: CHANGE "diatomaceous earth" } \\
\text { to "absorbent". }\end{array}$ & . & & $\because$ \\
\hline
\end{tabular}




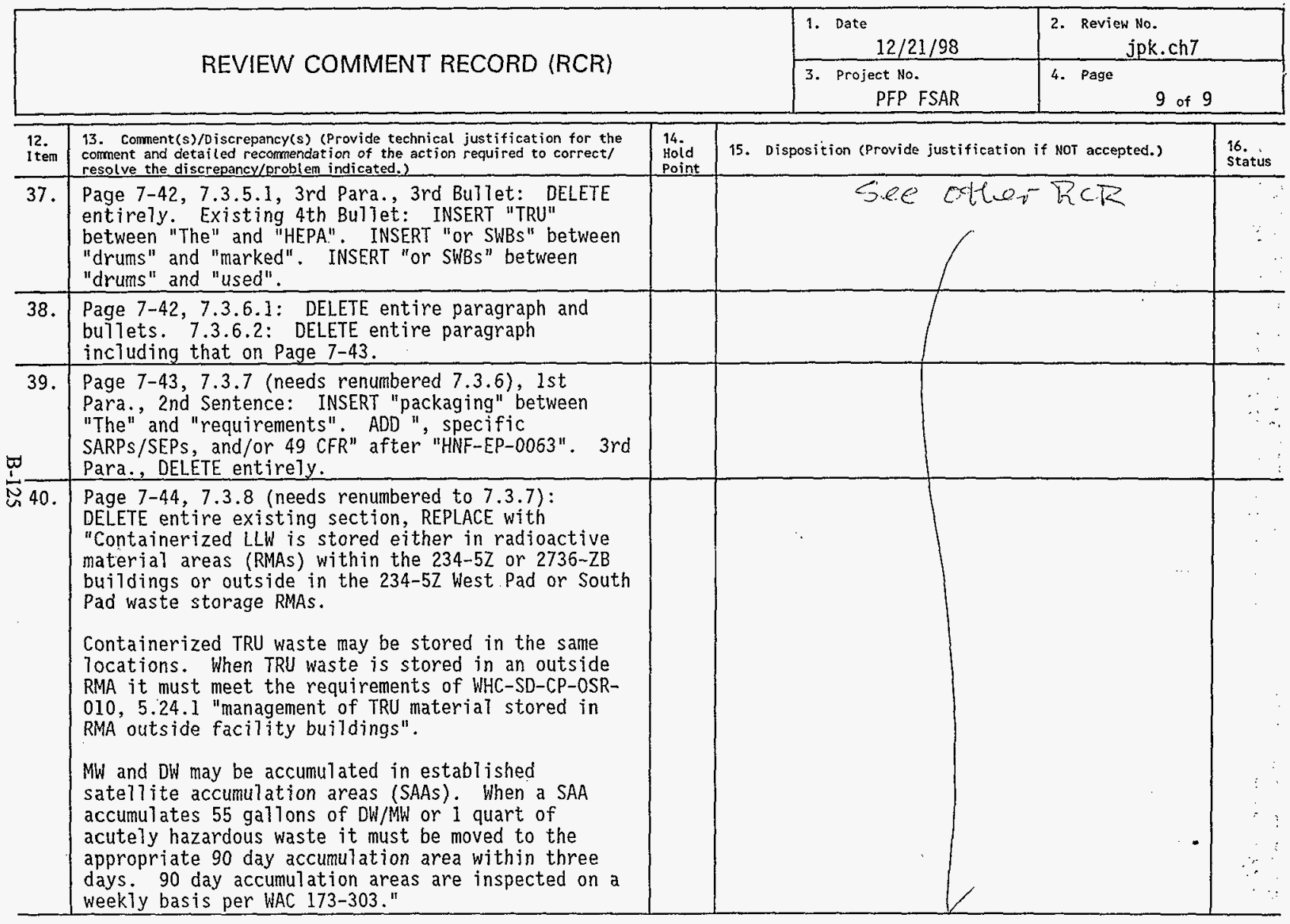




\begin{tabular}{|c|c|c|}
\hline & $\begin{array}{l}\text { 1. Date } \\
12 / 21 / 98 \\
\end{array}$ & $\begin{array}{r}\text { 2. Review No. } \\
\text { jpk.ch7 }\end{array}$ \\
\hline REVIEW COMMENT RECORD (RCR) & $\begin{array}{l}\text { 3. Project No. } \\
\text { PFP FSAR }\end{array}$ & $\begin{array}{l}\text { 4. Page } 10 \text { of } 9 \\
\end{array}$ \\
\hline
\end{tabular}

\begin{tabular}{|c|c|c|c|c|}
\hline $\begin{array}{l}12 . \\
\text { I tem }\end{array}$ & $\begin{array}{l}\text { 13. Comment }(\$) / 0 \text { iscrepancy(s) (provide technical justification for the } \\
\text { comment and detailed recommendation of the action required to correct/ } \\
\text { resolve the discrepancy/problem indicated.) }\end{array}$ & $\begin{array}{l}\text { 14.id } \\
\text { Hoid } \\
\text { Point }\end{array}$ & 15. Disposition (Provide justification if NOT accepted.) & $\begin{array}{l}16 . \\
\text { Status }\end{array}$ \\
\hline 41. & $\begin{array}{l}\text { Page } 7-45,7.5 \text { lst sentence DELETE which do not meet } \\
\text { Hanford Site WAC particvle size requirements. } \\
\text { 2nd sentence DELETE 0.5L polyjar, INSERT approved } \\
\text { between with and plant, CHANGE procedure to } \\
\text { procedures, DELETE Z0-160-060. 3rd sentence CHANGE } \\
\text { "bagged out of the glovebox" to "packaged". }\end{array}$ & & $\begin{array}{l}\text { Accept. Changes, wade os weted. } \\
\text {-vtece. }\end{array}$ & \\
\hline
\end{tabular}

$\underset{1}{\stackrel{1}{N}}$ 


\section{Johnson, LE (Safety Analysis)}

From:

Sent:

To:

Cc:

Subject:
Backlund, Ernest G (Gary)

Tuesday, December 22, 1998 10:28 AM

King, Jeffry P (Jeff); Johnson, LE (Safety Analysis); Ramble, Alan L; Hilliard, James R (Jim) Bramson, Jeffrey $E$ (Jeff)

RE: FSAR Rev, 1 Chapter 7 Review Comment Record.

You did a good job of interpreting our notes, but I have made a couple additions and a couple changes to your RCR. Changed the file name but left you on the RCR. I have gone over these with both Bramson and

Hilliard. Attached is the new file.

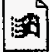

EGB.CH7

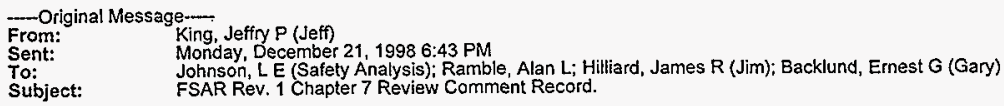

Attached in WP 5.1 file. Jim, Gary: Thanks for the quick turn-around on the review. Please check over and make sure I accurately captured your comments.

Jeff

« File: JPK.CH7 > 


\section{From:}

Sent:

To:

Cc:

Subject:
Ramble, Alan L.

Tuesday, December 22, 1998 12:41 PM Johnson, LE (Safety Analysis)

Ramble, Alan L

FW: PFR FSAR SITING CHAPTER

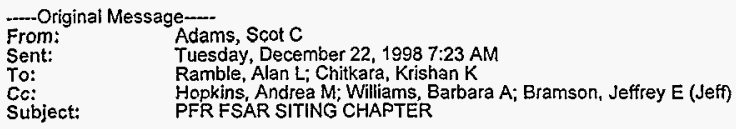

I have reviewed the siting chapter (3) of the PFP FSAR and have no comments. This is well written boiler plate.

However, on the next revision, I would recommend that a literature search be conducted. I believe there have been new publications related to fault mapping in the area.

The review on Chapter 7 Waste Confinement and Management is not done completely. The FDH Environmental Protection group reviewed air parts and have supplied some revisions. Separate functional support for review of other parts is in progress. Because of the noted revisions in the air part, I would infer that similar updates in the water part are expected. It is not expected that revisions will significantly relate to safety, only to environmental compliance.

$$
\text { Assin of Eug. Geologis ts - fanct trenching in arzect }
$$

Relative to the email of December 20-Where is the TriCities Professional Center? This might be hard to find without a street address, if you have not been there before today. The designation of the location seems to assume that everyone knows where it is. 


\begin{tabular}{|c|l|l|l|}
\hline \multirow{2}{*}{ REVIEW COMMENT RECORD (RCR) } & $\begin{array}{l}\text { 1. Date Review No. } \\
\text { JEB3 }\end{array}$ \\
\cline { 2 - 4 } & $\begin{array}{c}\text { 3. Project No. } \\
\text { PFP FSAR }\end{array}$ & $\begin{array}{l}\text { 4. Page } \\
1 \text { of } 3\end{array}$ \\
\hline
\end{tabular}

\begin{tabular}{l|l|l|l|l|l}
\hline 5. Document Number(s)/Title(s) & $\begin{array}{l}\text { 6. Program/Project/ } \\
\text { 8uilding Number } \\
\text { PFP FSAR }\end{array}$ & $\begin{array}{l}\text { 7. Reviewer } \\
\text { JE Bramson }\end{array}$ & $\begin{array}{l}\text { 8. Organization/Group } \\
\text { PFP Environmental } \\
\text { Compliance }\end{array}$ & 9. Location/Phone \\
\hline
\end{tabular}

17. Comment Submittal Approval:

Organization Manager (Optional)

㐫

\begin{tabular}{l|l|l|l|l}
\hline $\begin{array}{l}\text { I2. } \\
\text { Ite } \\
\text { m }\end{array}$ & $\begin{array}{l}\text { 13. Comment(s)/Discrepancy(s) (Provide technical justification } \\
\text { for the comment and detailed recommendation of the action required } \\
\text { to correct/ resolve the discrepancy/problem indicated.) }\end{array}$ & $\begin{array}{l}14 . \\
\text { Hold } \\
\text { Point }\end{array}$ & $\begin{array}{l}\text { 15. Disposition (Provide justification if NOT } \\
\text { accepted.) }\end{array}$ \\
\hline & $\begin{array}{l}\text { Additinal comments from cc:mail, JE Bramson to DM } \\
\text { Carson, FSAR Review: Chapter 7, dated 12/30/98 }\end{array}$ & & & \\
\hline
\end{tabular}

11. CLOSED
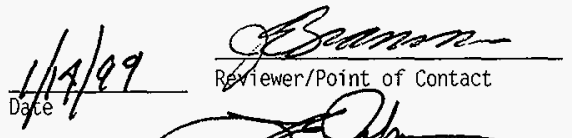

Refiewer/Point of Contact
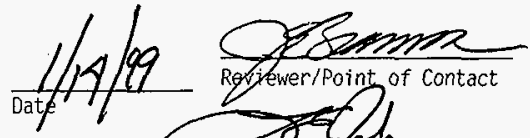

Rogiewer/Point of contact

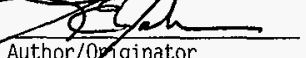

盾 


\begin{tabular}{|c|c|c|}
\hline \multirow{2}{*}{ REVIEW COMMENT RECORD (RCR) } & $\begin{array}{l}\text { 1. Date } \\
1 / 6 / 99\end{array}$ & $\begin{array}{r}\text { 2. Review No. } \\
\text { JEB3 }\end{array}$ \\
\hline & $\begin{array}{l}\text { 3. Project No. } \\
\text { PFP FSAR }\end{array}$ & 4. Page \\
\hline
\end{tabular}

\begin{tabular}{|c|c|c|c|c|}
\hline $\begin{array}{l}12 . \\
\text { Ite } \\
\text { m }\end{array}$ & $\begin{array}{l}\text { 13. Comment(s)/Discrepancy }(s) \text { (Provide technical justification } \\
\text { for the comment and detailed recommendation of the action required } \\
\text { to correct/ resolve the discrepancy/problem indicated.) }\end{array}$ & $\begin{array}{l}14 . \\
\text { Hold } \\
\text { Point }\end{array}$ & $\begin{array}{l}\text { 15. Disposition (Provide justification if NOT } \\
\text { accepted.) }\end{array}$ & $\begin{array}{l}\begin{array}{l}16 . \\
\text { Statu } \\
\text { s }\end{array} \\
\end{array}$ \\
\hline 㫣 & $\begin{array}{l}\text { [General Comments] Table 7-8. Revise the function } \\
\text { descriptions contained in Table } 7-8 \text { to read as } \\
\text { follows: } \\
\text { Sump Tank TK-D4 "Radioactive mixed waste storage } \\
\text { tank. Reserve storage capacity for tank overflows." } \\
\text { Sump Tank TK-D5 "Radioactive mixed waste storage and } \\
\text { treatment tank. Receives waste solution primarily } \\
\text { from storage tank TK-D8 with ability to receive from } \\
\text { TK-D7. A7l waste transfers to tank farms are } \\
\text { through tank TK-D5." } \\
\text { Sump Tank TK-D7 "Radioactive mixed waste storage } \\
\text { tank. Reserve storage capacity for tank overflows." } \\
\text { Sump Tank TK-D8 "Radioactive mixed waste storage and } \\
\text { treatment tank. Receives waste from PFP laboratory } \\
\text { and miscellaneous stabilization processes. Batch } \\
\text { transfers are made from TK-D8 to TK-D5." } \\
\text { Sump Tank TK-D4 }\end{array}$ & & $\begin{array}{l}\text { Accept. The text is revised for each of the } \\
\text { functional descriptions requested. }\end{array}$ & \\
\hline
\end{tabular}




\begin{tabular}{|l|l|l|l|}
\hline \multirow{2}{*}{ REVIEW COMMENT RECORD (RCR) } & $\begin{array}{l}\text { 1. Date Review No. } \\
\text { JEB3 }\end{array}$ & \begin{tabular}{l} 
1/6/99 \\
\cline { 1 - 3 }
\end{tabular} & $\begin{array}{c}\text { Project No. } \\
\text { PFP FSAR }\end{array}$ \\
\hline
\end{tabular}

\begin{tabular}{|c|c|c|c|c|}
\hline $\begin{array}{l}12 . \\
\text { Ite } \\
\mathbf{m}\end{array}$ & $\begin{array}{l}\text { 13. Comment(s)/Discrepancy(s) (Provide technical justification } \\
\text { for the comment and detailed recommendation of the action required } \\
\text { to correct/ resolve the discrepancy/problem indicated.) }\end{array}$ & $\begin{array}{l}14 . \\
\text { Hold } \\
\text { Point }\end{array}$ & $\begin{array}{l}\text { 15. Disposition (Provide justification if NOT } \\
\text { accepted.) }\end{array}$ & $\begin{array}{l}16 . \\
\text { Statu } \\
5 \\
\end{array}$ \\
\hline Фّ & $\begin{array}{l}\text { Figure } 7-4 \text {. Revise as follows: a marked-up copy of } \\
\text { the figure will be faxed showing the location of the } \\
\text { sites. Don't know the relevance of including those } \\
\text { sites that WIDS indicates as "cleaned-up" or } \\
\text { decontaminated, but I'l1 let you decide if they go } \\
\text { on the figure. } \\
\text { Replace the legend in its entirety with the } \\
\text { fol lowing: } \\
\text { Unp?anned Releases } \\
\text { 1. UPR-200-W-23 } \\
\text { 2. UPR-200-W-74 (soil removed) } \\
\text { 3. UPR-200-W-75 (soil removed) } \\
\text { 4. UPR-200-W-79 (decontaminated) } \\
\text { 5. UPR-200-W-89 (decontaminated) } \\
\text { 6. UPR-200-W-90 (decontaminated) } \\
\text { 7. UPR-200-W-91 } \\
\text { 8. UPR-200-W-103 (soil removed) } \\
\text { 9. UPR-200-W-159 (soil removed) } \\
\text { Soi1 Waste Management Units } \\
\text { 10. 216-Z-1D Ditch (inactive) } \\
\text { 11. 241-Z-361 (inactive) } \\
\text { 12. 241-Z TSD (active) } \\
\text { 13 234-5Z HWA (active) }\end{array}$ & & $\begin{array}{l}\text { The figure cannot be updated at this time. } \\
\text { A note will be added to the figure stating } \\
\text { "Figure needs updating with respect to } \\
\text { unplanned release sites." }\end{array}$ & \\
\hline
\end{tabular}




\section{REVIEW COMMENT RECORD (RCR)}

\begin{tabular}{|c|l|}
\hline \begin{tabular}{|l|} 
1. Date \\
$12 / 22 / 98$
\end{tabular} & 2. Review No. \\
\hline $\begin{array}{c}\text { 3. Project No. } \\
\text { PFP FSAR }\end{array}$ & 4. Page $\quad 1$ of 1 \\
\hline
\end{tabular}

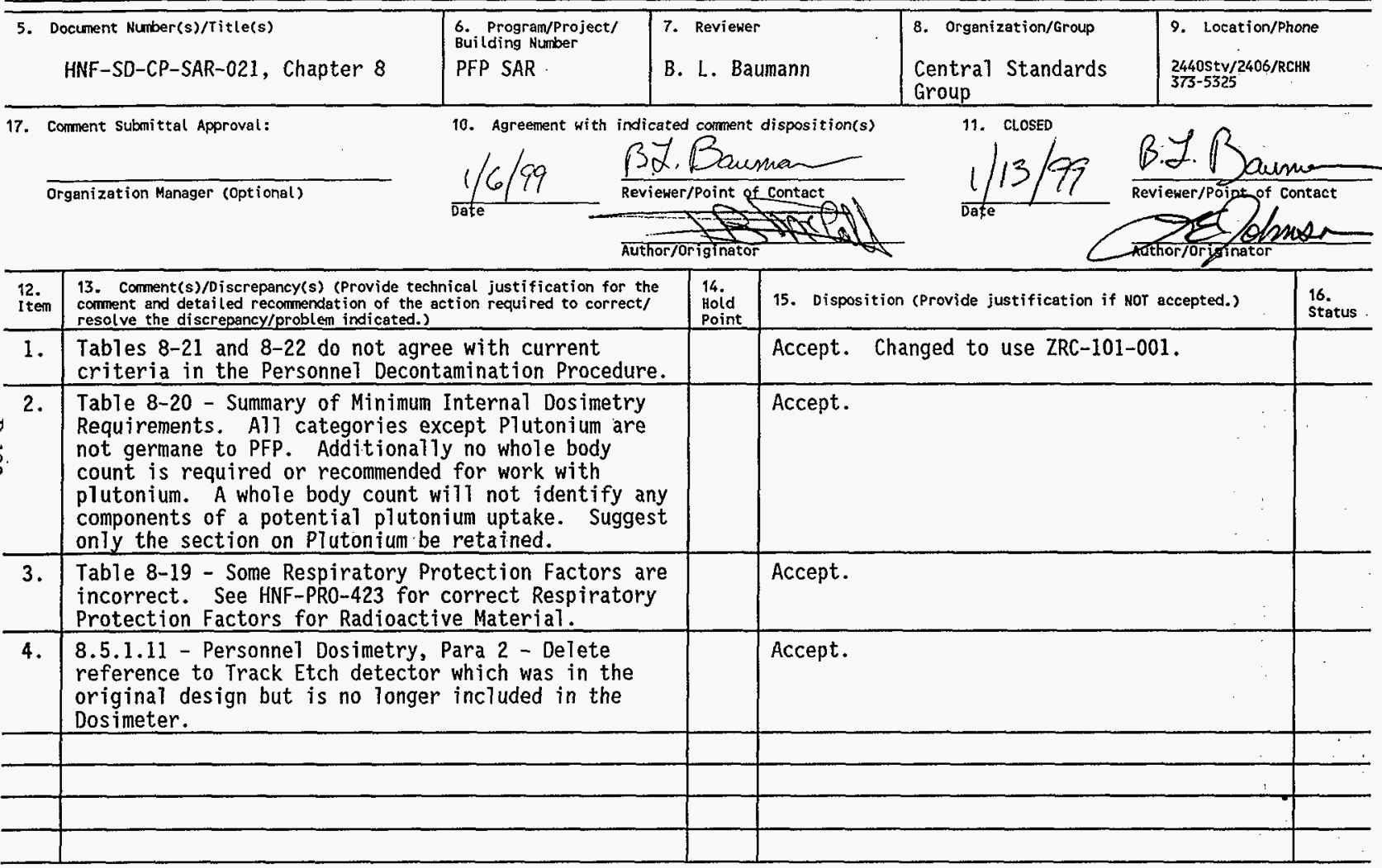




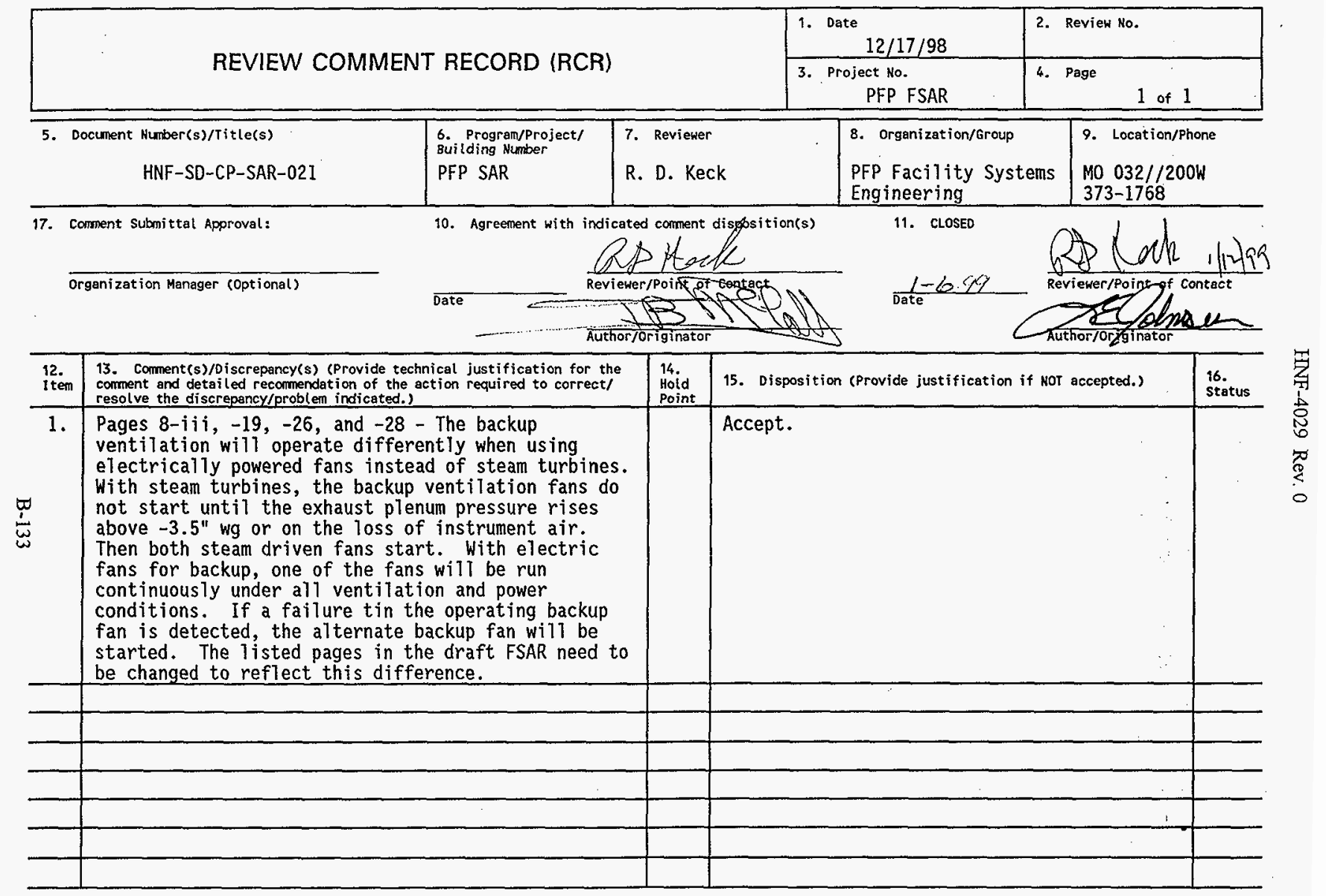




\begin{tabular}{|c|c|c|c|}
\hline \multirow{2}{*}{ REVIEW COMMENT RECORD (RCR) } & $\begin{array}{l}\text { 1. Date Revien No. } \\
\text { jpk. ch8 }\end{array}$ & $\begin{array}{c}12 / 21 / 98 \\
\text { 3. Project No. } \\
\text { PFP FSAR }\end{array}$ & $\begin{array}{l}4 . \text { Page } \\
1 \text { of } 9\end{array}$ \\
\hline
\end{tabular}

\begin{tabular}{|c|c|c|c|c|}
\hline $\begin{array}{l}\text { 5. Document Number(s)/Title(s) } \\
\text { WHC-SD-CP-SAR-021 Draft Rev. } 1 \\
\text { P] utonium Finishing PTant Final } \\
\text { Safety Analysis Report Chapter } 8\end{array}$ & $\begin{array}{l}\text { 6. Program/Project/ } \\
\text { Building number } \\
\text { PFP } \\
\text { Authorization } \\
\text { Basis }\end{array}$ & $\begin{array}{l}\text { 7. Reviewer } \\
\text { J.P. King }\end{array}$ & $\begin{array}{l}\text { 8. Organization/Group } \\
\text { PFP Ops/15310 }\end{array}$ & $\begin{array}{l}\text { 9. Location/Phone } \\
270-2 / 373-5194 \text {. }\end{array}$ \\
\hline
\end{tabular}
Safety Analys is Report Chapter 8

17. Coment submittal Approval:

10. Agreement with indicated comment disposition(s)

\section{CLOSED}
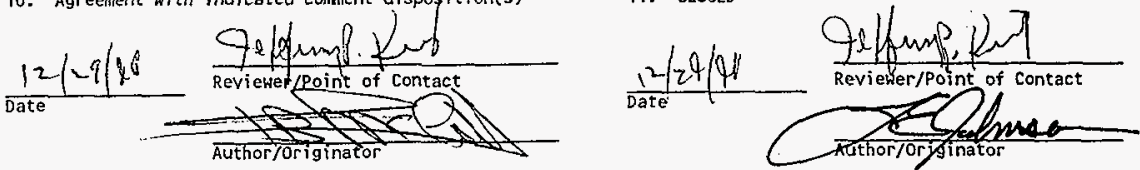

\begin{tabular}{|c|c|c|c|c|}
\hline $\begin{array}{l}12 . \\
\text { I tem }\end{array}$ & $\begin{array}{l}\text { 13. Comment( } s) / 0 \text { iscrepancy(s) (Provide technical justification for the } \\
\text { coment and detailed recommendation of the action required to correct/ } \\
\text { resolve the discrepancy/probtem indicated.) }\end{array}$ & $\begin{array}{l}14 . \\
\text { Hold } \\
\text { Point }\end{array}$ & 15. Disposition (Provide justification if NOT accepted.) & $\begin{array}{l}16 . \\
\text { Status }\end{array}$ \\
\hline $1 \sqrt{ }$ & $\begin{array}{l}\text { Page 8-iv, PREFACE, 3rd Para., 5th Sentence: DELETE } \\
\text { "operation and". } \\
\text { Actual operation of the backup electric fans will be } \\
\text { significantly different than the steam turbines. }\end{array}$ & & & \\
\hline $2 \sqrt{ }$ & $\begin{array}{l}\text { Page } 8-8,8.2 .1 .1 .1 \text {, 2nd Para.: DELETE. PRF tanks, } \\
\text { vessels, and equipment are essentially empty and do } \\
\text { not represent significant radiation sources. } \\
\text { Rather, the remaining sources are due to holdup and } \\
\text { heels in tanks, and general contamination on } \\
\text { equipment, in hood, and in the canyon. Table } 8-2 \text { is } \\
\text { also irrelevant to radiation protection and should } \\
\text { be deleted. }\end{array}$ & & Inconp. & $\therefore$ \\
\hline$\therefore$ & $\begin{array}{l}\text { Page } 8-9,8.2 .1 .1 .1 \text {, 4th Para.: ADD "HA-22B" } \\
\text { between HA-21I and HA-23S. By the time this FSAR } \\
\text { revision is issued, we should be able to reactivate } \\
\text { HA-22B in support of thermal stabilization } \\
\text { operations. }\end{array}$ & & 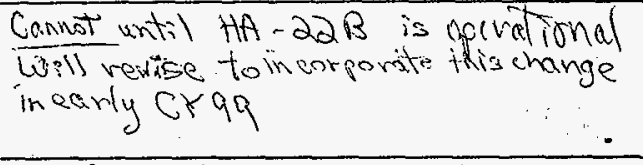 & \\
\hline 4 & $\begin{array}{l}\text { Page } 8-20,8.3 .1 .2 \text { : DELETE } 6 \text { th sentence. It is } \\
\text { only applicable to one of the several different } \\
\text { types of PR cans in use. }\end{array}$ & & $\begin{array}{l}\text { Page } 20 \text { paragraph } F \text { Figure } 8-3 \\
\text { have been moditiod to state "fypical" }\end{array}$ & \\
\hline
\end{tabular}




\begin{tabular}{|c|l|l|l|}
\hline REVIEW COMMENT RECORD (RCR) & $\begin{array}{l}\text { i. Date Review No.' } \\
\text { jpk. ch8 }\end{array}$ & $\begin{array}{l}12 / 21 / 98 \\
\text { 3. Project No. } \\
\text { PFP FSAR }\end{array}$ \\
\hline
\end{tabular}

\begin{tabular}{|c|c|c|c|c|}
\hline $\begin{array}{l}12 . \\
\text { Iten }\end{array}$ & $\begin{array}{l}\text { 13. Corment(s)/Discrepancy(s) (Provide technical justification for the } \\
\text { comment and detailed recommendation of the action required to correct/ } \\
\text { resolve the discrepancy/problem indicated.) }\end{array}$ & $\begin{array}{l}\text { 14. } \\
\text { Hold } \\
\text { Point }\end{array}$ & 15. Disposition (Provide justification if NOT accepted.) & $\begin{array}{l}16 . \\
\text { status }\end{array}$ \\
\hline $5 \sqrt{ }$ & $\begin{array}{l}\text { Page 8-21, 8.3.1.6, 3rd Para., 4th Sentence: ADD } \\
\text { "Most" in front of "Airlocks". Not all airlocks } \\
\text { have alarms. }\end{array}$ & & (Acrest) & \\
\hline$\sqrt[6]{1}$ & $\begin{array}{l}\text { Page 8-22, 8.3.1.7, 4th Para., last Sentence: } \\
\text { DELETE "The other types of survey instrumentation } \\
\text { used within PFP are shown in Figure 8-14". Figure } \\
8-14 \text { is not inclusive of all survey instrumentation } \\
\text { used at PFP. Locations of survey instrumentation in } \\
\text { the plant change continuously depending upon } \\
\text { programmatic needs within the plant. Figure } 8-14 \\
\text { should be deleted because of this. }\end{array}$ & & f & \\
\hline $7 \sqrt{ }$ & $\begin{array}{l}\text { Page } 8-24,8.3 .2 .1 .10 \text {. CHANGE to "This storage area } \\
\text { contains inactive gloveboxes once used for ...." } \\
\text { The 1-ft reinforced concrete walls reduced ..." ADD: } \\
\text { "Waste drums in the process of being filled are } \\
\text { currently staged in the room." }\end{array}$ & & $\bar{A}$ & \\
\hline$\sqrt[81]{1}$ & $\begin{array}{l}\text { Page 8-26, 8.3.3.1.2, lst buTlet: Entire } \\
\text { description of the new backup ventilation system is } \\
\text { wrong. Two non-modulating electric exhaust fans } \\
\text { will be able to be powered from diesel power. One } \\
\text { of the two will be in operation at al1 times under } \\
\text { normal power. If normal power is lost, non backup } \\
\text { powered fans will coast to a stop and the } 2721-Z \\
\text { diesels will pick up and continue to power the one } \\
\text { backup fan that was in service at the time of the } \\
\text { power loss. The } 2736-2 A \text { generator has also been } \\
\text { removed. Backup power for its ventilation will } \\
\text { also come from the } 2721-z \text { generators. }\end{array}$ & & $\begin{array}{l}\text { Accert. REWRTE RER COMmENTS FROM } \\
\text { ROGER KECK }\end{array}$ & \\
\hline 9 & $\begin{array}{l}\text { Page } 8-27,8.3 .3 .1 .6, \text { 1st bullet: DELETE. The } \\
\text { fluorinator (inactive) E-4 path has been el iminated. }\end{array}$ & & ACCEPT. & \\
\hline
\end{tabular}




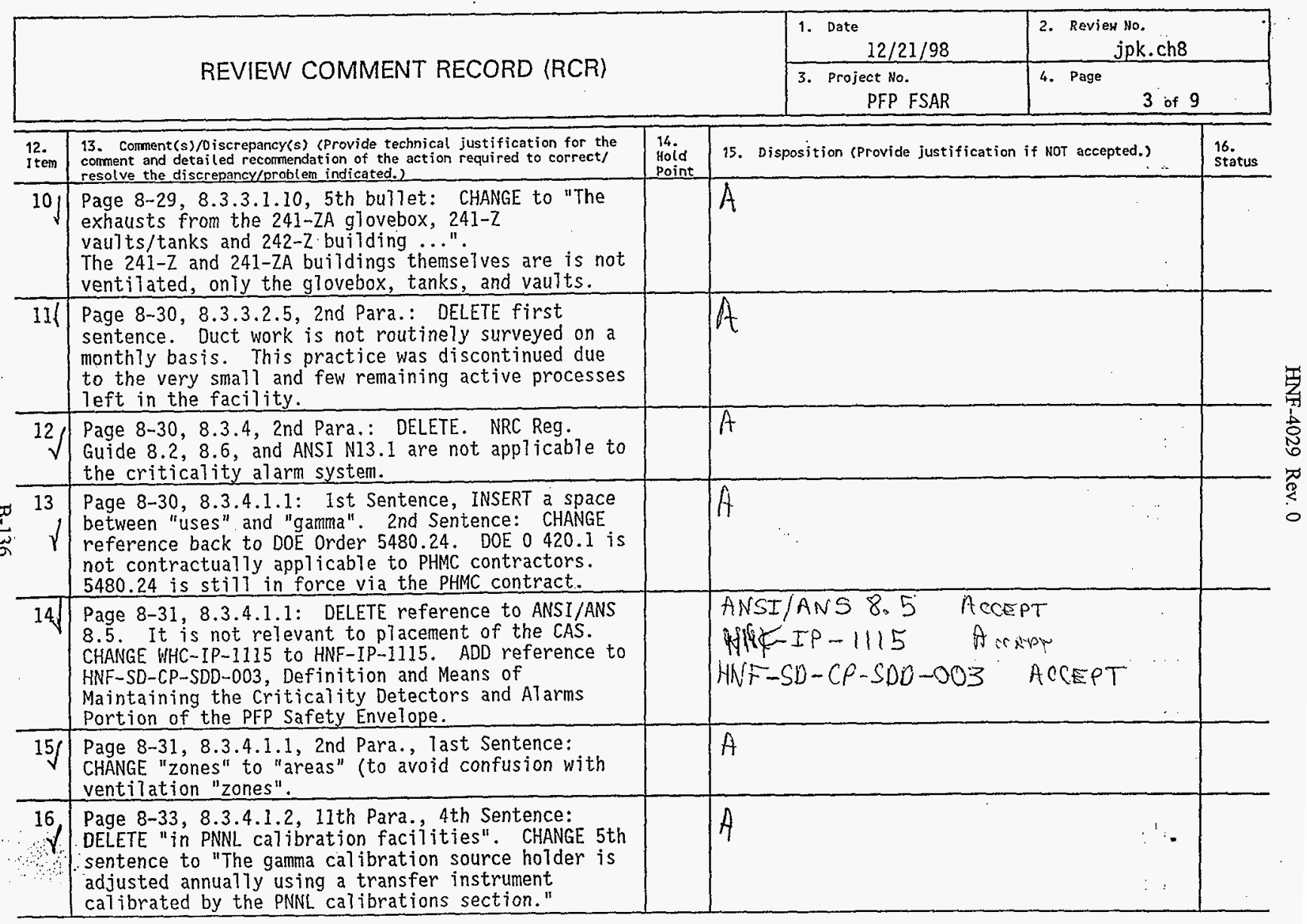




\begin{tabular}{|c|l|l|l|}
\hline REVIEW COMMENT RECORD (RCR) & $\begin{array}{l}\text { 1. Date } \\
\text { 12/21/98 Review No. } \\
\text { jpk.ch8 }\end{array}$ & $\begin{array}{c}\text { 3. Project No. } \\
\text { PFP FSAR }\end{array}$ & $\begin{array}{l}4 . \text { Page } \\
4\end{array}$ \\
\hline
\end{tabular}

\begin{tabular}{|c|c|c|c|c|}
\hline \begin{tabular}{l|l|}
12. \\
Item
\end{tabular} & $\begin{array}{l}\text { 13. Corment }(s) / D \text { iscrepancy(s) (Provide technical justification for the } \\
\text { comment and detailed recommenciation of the action regujed to correct/ } \\
\text { resolve the discrepancy/problem indicated.) }\end{array}$ & $\begin{array}{l}14 . \\
\text { Hold } \\
\text { Point }\end{array}$ & 15. Disposition (Provide justification if Not accepted.) & $\begin{array}{l}\text { 16. } \\
\text { status }\end{array}$ \\
\hline 17 & $\begin{array}{l}\text { Page 8-33, 8.3.4.1.2, 12th Para.: CHANGE to "Each } \\
\text { gamma detector and detector module within the PFP is } \\
\text { cal ibrated at least annually and functionally tested } \\
\text { at least monthly." }\end{array}$ & & A & \\
\hline $18 \mathrm{~g}$ & $\begin{array}{l}\text { Page } 8-33,8.3 .4 .1 .3 \text {, 4th Para.: CHANGE WHC-IP-1115 } \\
\text { reference to HNF-IP-1115. }\end{array}$ & & WWWE-1P-1115 & \\
\hline$\sqrt{19}$ & $\begin{array}{l}\text { Page } 8-35,8.3 .4 .1 .4,13 \text { Para, 1st Sentence: } \\
\text { DELETE "and } 3.2 \text { "Confinement/Ventilation Systems". } \\
\text { CHANGE 2nd Sentence to "Notification of a "No } \\
\text { Fissile Movement" restriction is requirement before } \\
\text { the outage action starts, or if the outage is } \\
\text { unplanned, notification is made within the } \\
\text { compensatory action completion time specified in OSR } \\
\text { LCO 3.1.2." }\end{array}$ & & $A$ & \\
\hline$\sqrt{20}$ & $\begin{array}{l}\text { Page } 8-35,8.3 .5, \text { ist Para.: Correct reference is } \\
\text { Plutonium Finishing Plant Administrative Procedure } \\
\text { ZAP-000-009, "Workplace Air Monitoring Program". } \\
\text { The procedure is a compilation of requirements } \\
\text { applicable to PFP workplace air sampling. DELETE } \\
\text { existing 2nd and 3rd sentences. }\end{array}$ & & A & \\
\hline$\sqrt{21}$ & $\begin{array}{l}\text { Page } 8-36,8.3 .5 .2 .2,3 \text { rd Para., 2nd Sentence: } \\
\text { DELETE reference to Figure } 8-13 \text {. CHANGE to } \\
\text { "Representative CAM locations at the PFP Complex are } \\
\text { documented in drawing } \mathrm{H}-2-80107 . "\end{array}$ & & $A$ & . \\
\hline$\sqrt{22}$ & $\begin{array}{l}\text { Page } 8-37,8.3 .5 .2 .2,5 \text { th Para. 3rd Sentence: } \\
\text { DELETE "either the fiber or". Membrane filters are } \\
\text { used in al1 PFP CAMs and FHSS. }\end{array}$ & & f & \\
\hline 23 & $\begin{array}{l}\text { Page } 8-37,8.3 .5 .2 .2,7 \text { th Para, last Sentence: } \\
\text { INSERT "2736-ZB and } 2736-Z \text { Vauit" in front of "room } \\
\text { CAM alarms". (these are the only ones that alarm in } \\
\text { Rooms } 631 \text { and } 221 \mathrm{~A} \text { ) }\end{array}$ & & 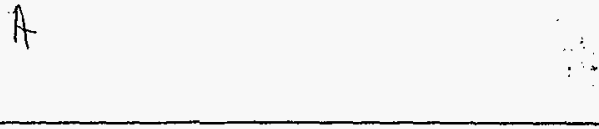 & \\
\hline
\end{tabular}




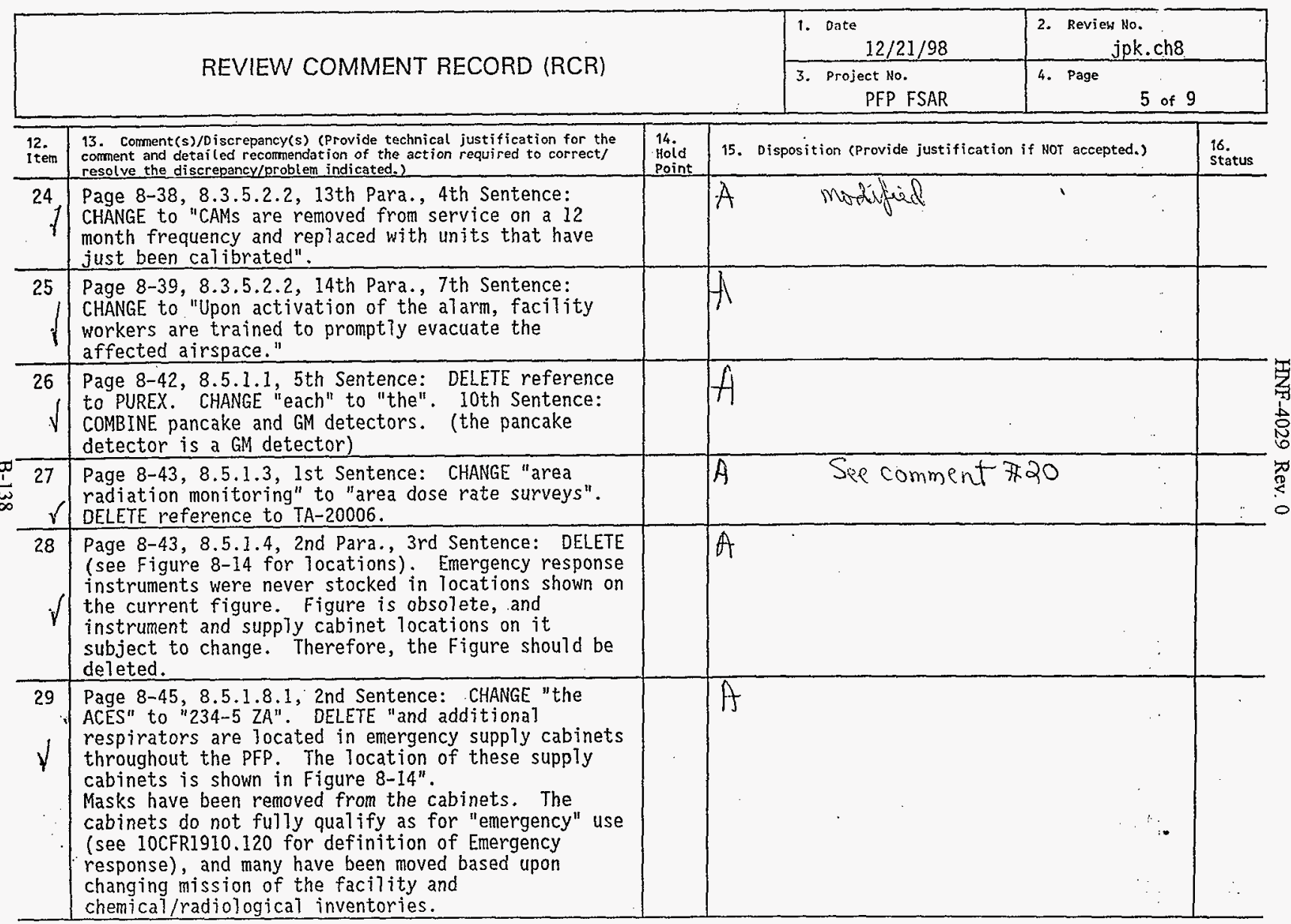




\begin{tabular}{|c|c|c|}
\hline & $\begin{array}{l}\text { 1. Date } \\
12 / 21 / 98 \\
\end{array}$ & $\begin{array}{l}\text { 2. Review No. } \\
\text { jpk.ch8 }\end{array}$ \\
\hline REVIEW COMMEN I RECORD (RCK) & $\begin{array}{l}\text { 3. Project No. } \\
\text { PFP FSAR }\end{array}$ & 4. Page 6 of 9 \\
\hline
\end{tabular}

\begin{tabular}{|c|c|c|c|c|}
\hline I2. & $\begin{array}{l}\text { 13. Comment(s)/Discrepancy(s) (Provide technical justification for the } \\
\text { comment and detailed recommendation of the action required to correct/ } \\
\text { resolve the discrepancy/problem indicated.) }\end{array}$ & $\begin{array}{l}14 . \\
\text { Hoid } \\
\text { Point }\end{array}$ & 15. Disposition (Provide justification if NOT accepted.) & $\begin{array}{l}16 . \\
\text { Status } \\
\end{array}$ \\
\hline$\sqrt[30]{10}$ & $\begin{array}{l}\text { Page } 8-46,8.5 .1 .8 .2 \text {, 2nd Sentence: DELETE. RC } \\
\text { wil7 no longer be issuing these. Matter is } \\
\text { irrelevant to how the PAPR functions. }\end{array}$ & & A & \\
\hline $\begin{array}{l}31 \\
1\end{array}$ & $\begin{array}{l}\text { Page 8-46, 8.5.1.8.4: CHANGE to "SCBA units are } \\
\text { available at selected locations throughout the PFP } \\
\text { Current locations of SCBA units within the PFP are } \\
\text { determined by plant mission, radiological spill } \\
\text { response, chemical spill response, and Resource } \\
\text { Conservation and Recovery Act (RCRA) storage } \\
\text { requirements. The SCBA units are inspected at } \\
\text { established frequencies in accordance with plant and } \\
\text { site procedures. A typical SCBA unit is shown in } \\
\text { Figure 8-39. The SCBA is primarily used for } \\
\text { emergency response and in IDLH atmospheres. The } \\
\text { SCBA is also used by personnel when responding to } \\
\text { alarm situations in areas where airborne hazards } \\
\text { have not been quantified and maximum respiratory } \\
\text { personnel protection factors are warranted. These } \\
\text { units are similar to the pressure-demand airline } \\
\text { respirators, except that the air supply is via a } \\
\text { cylinder of compressed air carried by the wearer. } \\
\text { The SCBA offers equal or greater protection than the } \\
\text { supplied air respirators. The device will provide } \\
\text { time } 7 \text { imited protection, due to the amount of air in } \\
\text { the apparatus. SCBA training is reguired annually. }\end{array}$ & & : & \\
\hline 32 & $\begin{array}{l}\text { Page } 8-48,8.5 .1 .11 .3,3 \text { rd Sentence: DELETE } \\
\text { reference to "hardwa71" REPLACE with "G-M probe". } \\
\text { CHANGE "gamma-type" to "count rate meter". 4th } \\
\text { Sentence: CHANGE hardwall gamma" to "G-M". }\end{array}$ & & $A$ & \\
\hline 33 & $\begin{array}{l}\text { Page } 8-50,8.5 .2 .1 \text {, 5th Sentence: INSERT "beta and" } \\
\text { between "for" and "gamma". DELETE existing ( } 8 \text { th } \\
\text { sentence. }\end{array}$ & & 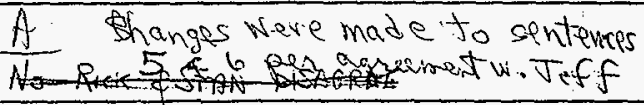 & \\
\hline
\end{tabular}




\begin{tabular}{|c|c|c|c|}
\hline REVIEW COMMENT RECORD (RCR) & $\begin{array}{l}\text { Date Review No. } \\
\text { jok. ch8 }\end{array}$ & $\begin{array}{c}\text { 3. Project No. } \\
\text { PFP FSAR }\end{array}$ \\
\hline
\end{tabular}

\begin{tabular}{|c|c|c|c|c|}
\hline $\begin{array}{l}12 . \\
\text { Item }\end{array}$ & $\begin{array}{l}\text { 13. Comment(s)/Discrepancy(s) (Provide technical justification for the } \\
\text { comment and detailed recommendation of the action required to correct/ } \\
\text { resolve the discrepancy/problem indicated.) }\end{array}$ & $\begin{array}{l}\text { 14. } \\
\text { Hoid } \\
\text { Point }\end{array}$ & 15. Disposition (Provide justification if NOT accepted.) & $\begin{array}{l}16 . \\
\text { Status }\end{array}$ \\
\hline$\sqrt[34]{14}$ & $\begin{array}{l}\text { Page } 8-56,8.5 .2 .5 .2, \text { 3rd Para., 1st Sentence: } \\
\text { DELETE "aipha sensitive CAMs", DELETE "and } \\
\text { criticality monitors". } \\
\text { Plant forces do not cal ibrate alpha CAMs. The CAS } \\
\text { is not subject to the requirements of HNF-PRO- } 436 \text {. }\end{array}$ & & 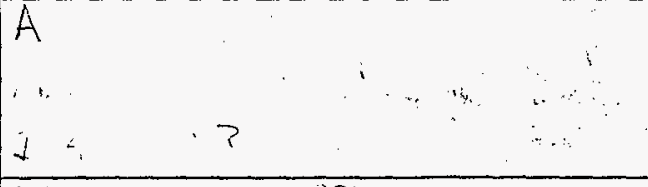 & " . \\
\hline $\begin{array}{r}35 \\
1\end{array}$ & $\begin{array}{l}\text { Page } 8-58,8.5 .6 .2 \text {, 1st Para., lst Sentence: CHANGE } \\
\text { to "PFP hazardous material and routine radiation } \\
\text { workers recejve medical examinations." } 2 \text { nd Para: } \\
\text { DELETE existing } 1 \text { st and } 2 \text { nd sentences. }\end{array}$ & & $\begin{array}{l}\text { 1st senternes: } A \\
\text { Qnd: Af }\end{array}$ & \\
\hline$\sqrt[36]{16}$ & $\begin{array}{l}\text { Page } 8-62,8.5 .2 .9 \text {, 9th Para.: DELETE entirely. } \\
\text { This practice was abandoned by PFP Rad. Con. years } \\
\text { ago. }\end{array}$ & & $f y$ & \\
\hline 1 & $\begin{array}{l}\text { Page } 8-66,8.6 .1 .1 .1 \text {, lst Para., 4th Sentence: } \\
\text { DELETE reference to ANSI N42.18. PFPS' eff] } \\
\text { monitors } \\
\text { mon NOT meet the reguirements of N42.18. }\end{array}$ & & 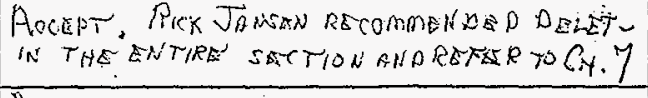 & \\
\hline$\sqrt[38]{ }$ & $\begin{array}{l}\text { Page } 8-66,8.6,1.1 .1, \text { 2nd Para. } \\
\text { CORRECT reference to HNF-EP-0527 (FDH 1997). }\end{array}$ & & saine is above & \\
\hline$\sqrt[39]{19}$ & $\begin{array}{l}\text { Page } 8-69,8.6 .2 \text {, Ist Para., 3rd Sentence: CHANGE } \\
\text { "considering" to "considered". }\end{array}$ & & (2) & \\
\hline $40 \mathrm{f}$ & $\begin{array}{l}\text { Page R8-2: DELETE reference to ANSI/ANS } 8.5 \text {. } \\
\text { CHANGE reference to DOE } 0420.1 \text { back to DOE Order } \\
5480.24 \text { (in accordance with current PHMC contract } \\
\text { summary). }\end{array}$ & & A & \\
\hline$\sqrt[41]{ }$ & $\begin{array}{l}\text { Page R8-4: CHANGE reference to WHC-IP-1115 to HNF- } \\
\text { IP-1115. }\end{array}$ & & $A$ & \\
\hline 42 & $\begin{array}{l}\text { Pages T8-2 through T8-5, DELETE entire Table } 8-2 \text {. } \\
\text { Is of no relevance to current plant operations or } \\
\text { configuration. }\end{array}$ & & $A$ & \\
\hline
\end{tabular}




\section{REVIEW COMMENT RECORD (RCR)}

\begin{tabular}{|c|c|}
\hline $\begin{array}{l}\text { 1. Date } \\
12 / 21 / 98\end{array}$ & $\begin{array}{l}\text { 2. Review No. } \\
\text { jpk.ch8 }\end{array}$ \\
\hline $\begin{array}{c}\text { 3. Project No. } \\
\text { PFP FSAR }\end{array}$ & 4. Page 8 of 9 \\
\hline
\end{tabular}

\begin{tabular}{|c|c|c|c|c|}
\hline $\begin{array}{l}12 . \\
\text { Item }\end{array}$ & $\begin{array}{l}\text { 13. Corment(s)/Discrepancy(s) (Provide tecknical justification for the } \\
\text { corment and detailed recommendation of the action required to correct/ } \\
\text { resotve the discrepancy/problem indicated.) }\end{array}$ & $\begin{array}{l}14 . \\
\text { Hoid } \\
\text { Point }\end{array}$ & 15. Disposition (Provide justification if NOT accepted.) & $\begin{array}{l}16 . \\
\text { Status }\end{array}$ \\
\hline$\sqrt[43]{ }$ & $\begin{array}{l}\text { Pages T8-6 though T8-8, DELETE a } 17 \text { references to } \\
\text { equipment not required for future missions. This } \\
\text { leaves only } \mathrm{HC}-227 \mathrm{~S} \text { in the table. }\end{array}$ & & $\begin{array}{l}\text { Partial: } H C-1, H C-2275 \text { remain } \\
\text { But Jeffesick want Toble } 8-3 \text { rem }\end{array}$ & oved \\
\hline 44 & $\begin{array}{l}\text { Pages T8-10 through T8-12, ANNOTATE the following } \\
\text { gloveboxes/hoods/proeesses as inactive: HC } 60 \text {, HA- } \\
40 F \text {, HA-46F, H-7A, (H-9A) MT-1, Transfer hood, MT-3, } \\
\text { MT-4, MT-5, MT-6, Canning/Loading, Charging hood, }\end{array}$ & & & \\
\hline$\sqrt{ }$ & $\begin{array}{l}\text { Glovebox I Room } 145 \text {, Glovebox } 552 \text {, Room } 152 \text {. DELETE } \\
\text { reference to H=9A on page T8-12, this is a dupl icate } \\
\text { entry from page T8-10. CORRECT listing of H-9A on } \\
\text { page T8-10. }\end{array}$ & & be H-AA & \\
\hline$\sqrt[45]{1}$ & $\begin{array}{l}\text { Page T8-26: DELETE reference to Room } 112 \text {, Men's } \\
\text { changeroom. This has been replaced by } 234-5 Z \text { A (not } \\
\text { a radioactive material building). }\end{array}$ & & fi & \\
\hline $\begin{array}{l}46 \\
27 \\
17\end{array}$ & $\begin{array}{l}\text { Page T8-14: CHANGE description of Room } 161 \text { to RMC } \\
\text { Line Shift Operations. CHANGE description of Room } \\
162 \text { to Solid Waste Operations. Area occupancy is } \\
\text { approximately } 4 \text { hours/day. CHANGE description of } \\
\text { Room } 166 \text { to "Inactive RMC Line batch tanks/SWO drum } \\
\text { operations". Area occupancy is about } 1 \mathrm{hr} / \mathrm{day} \text {. }\end{array}$ & & A & \\
\hline$\sqrt[47]{3}$ & $\begin{array}{l}\text { Page T8-31: Change Area Occupancy for all of } 236-\mathrm{Z} \\
\text { to approximately } 1 \mathrm{hr} / \text { day per room. (Some, like } \\
\text { welding shop may justify a } 0 \text { ). }\end{array}$ & & $A$ & \\
\hline $48 /$ & $\begin{array}{l}\text { Page T8-32: Change Area Occupancy for } 241-2 A \text { to } 1 \\
\text { hr/month. }\end{array}$ & & $A$ & \\
\hline 49 & $\begin{array}{l}\text { Page T8-37, Table 8-18: DELETE reference to AMS-3 } \\
\text { Beta CAMs. }\end{array}$ & & ins & \\
\hline$\sqrt[50 / 1]{ }$ & $\begin{array}{l}\text { Page F8-3, Figure 8-3: CHANGE title to "Typical } \\
\text { Product Receiver Can Assembly" }\end{array}$ & & A & \\
\hline$\sqrt[51]{1}$ & $\begin{array}{l}\text { Pages F8-19 through F8-21: DELETE Figure 8-13 } \\
\text { entirely. Refer to drawing } \mathrm{H}-2-80107 \text {. }\end{array}$ & & A & \\
\hline
\end{tabular}




\begin{tabular}{|c|c|c|}
\hline & $\begin{array}{l}\text { 1. Date } \\
12 / 21 / 98\end{array}$ & $\begin{array}{r}\text { 2. Review No. } \\
\text { jpk. ch8 }\end{array}$ \\
\hline REVIEW COMMENT RECORD (RCR) & $\begin{array}{l}\text { 3. Project No. } \\
\text { PFP FSAR }\end{array}$ & 4. Page 9 of 9 \\
\hline
\end{tabular}

\begin{tabular}{|c|c|c|c|c|}
\hline $\begin{array}{l}\text { 12. } \\
\text { Item }\end{array}$ & $\begin{array}{l}\text { 13. Comment(s)/Discrepancy(s) (Provide technical justification for the } \\
\text { comment and detailed recommendation of the action required to correct/ } \\
\text { resolve the discrepancy/problem indicated.) }\end{array}$ & $\begin{array}{l}14 . \\
\text { Hold } \\
\text { point }\end{array}$ & 15. Disposition (Provide justification if nOT accepted.) & $\begin{array}{l}\text { 16. } \\
\text { status }\end{array}$ \\
\hline$\sqrt[52]{1}$ & $\begin{array}{l}\text { Page F8-22 through F8-26: DELETE Figure } 8-14 \\
\text { entirely. Locations of survey equipment are subject } \\
\text { to frequent changes, emergency equipment is not } \\
\text { realiy emergency equipment (that stuff is brought in } \\
\text { by the Haz-Mat/Fire Dept when they respond), } \\
\text { locations of supplies that were in the cabinets are } \\
\text { subject to frequent change. }\end{array}$ & & $A$ & \\
\hline 53 & Page F8-32, Figure 8-20: ADO "Typical" to title. & & A & \\
\hline 54 & $\begin{array}{l}\text { Page F8-39 through F8-42, Figure 8-27: DELETE } \\
\text { figure. Refer to drawings } \mathrm{H}-2-28885, \mathrm{H}-2-80143 \text {, } \mathrm{H}- \\
2-28888 \text {, and } \mathrm{H}-2-91823 \text {. }\end{array}$ & & $A$ & \\
\hline & & & & \\
\hline & & & & \\
\hline & & & $\because$ & \\
\hline
\end{tabular}

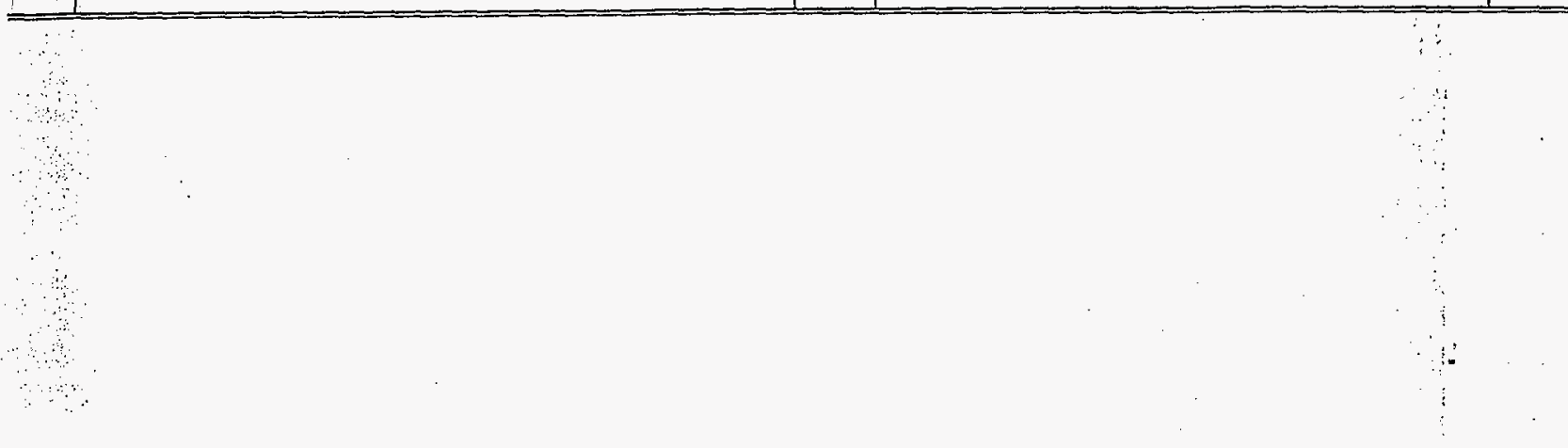




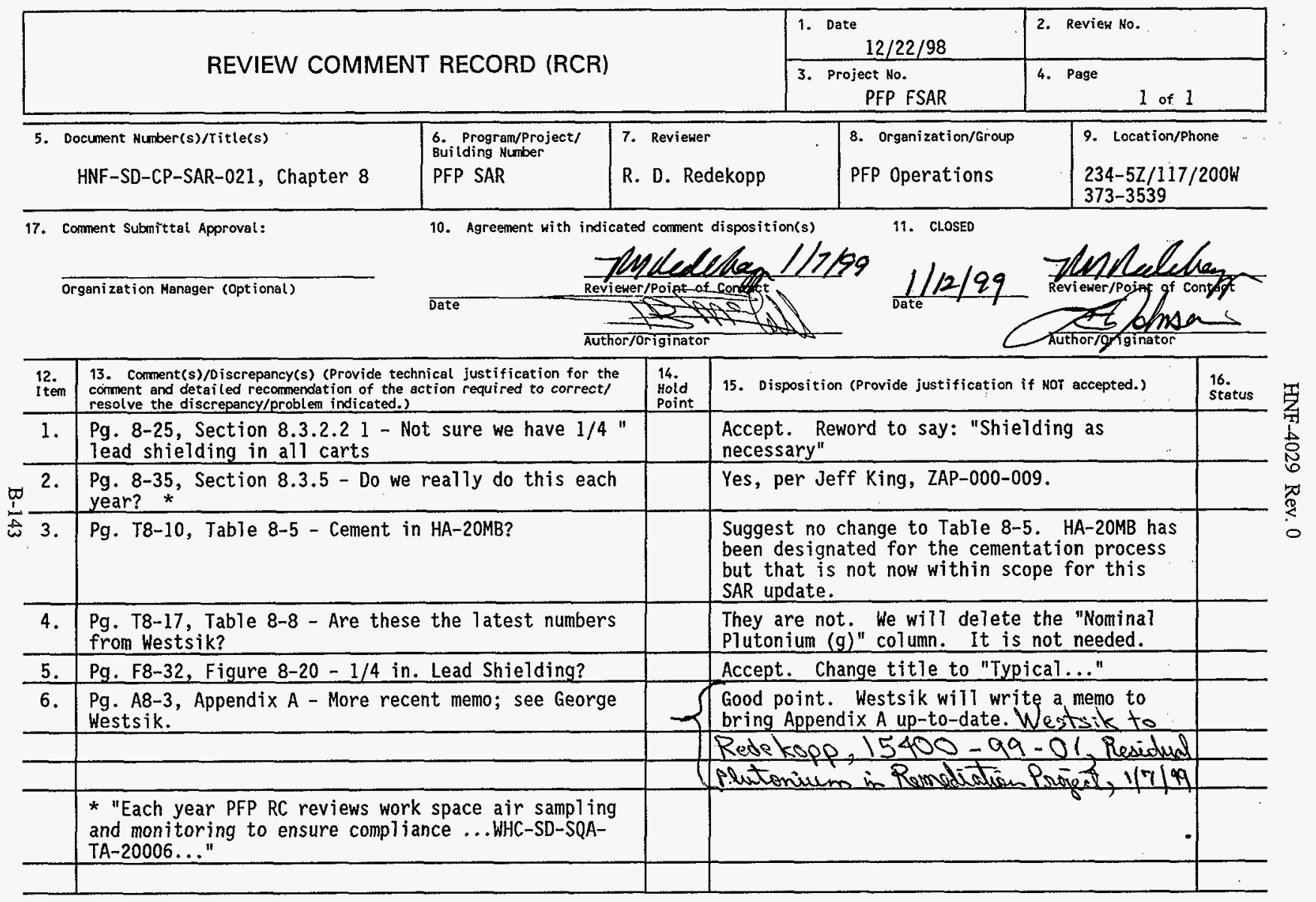




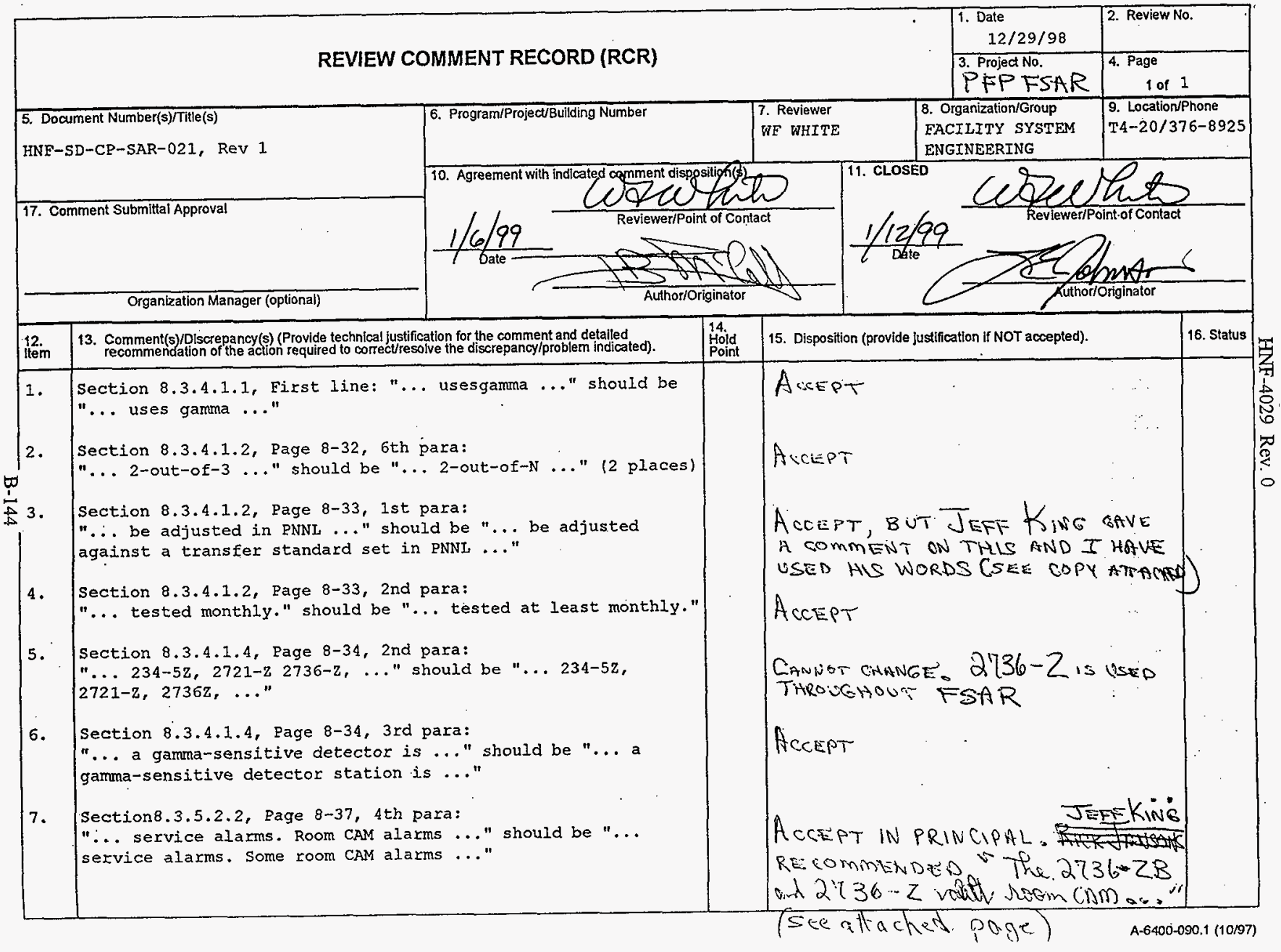




\section{REVIEW COMMENT RECORD (RCR)}

\begin{tabular}{|c|l|}
\hline $\begin{array}{l}\text { 1. Date } \\
12 / 18 / 98\end{array}$ & 2. Review No. \\
\hline $\begin{array}{c}\text { 3. Project No. } \\
\text { PFP FSAR }\end{array}$ & 4. Page \\
\hline
\end{tabular}

5. Document Number(s)/Title(s)

HNF-SD-CP-SAR-021, Chapter 8

17. Comment Submittal Approval:

Organization Manager (Optional)
6. Program/Project/ Building Number

PFP SAR

10. Agreement with indicated corment disposition(s)

$$
\frac{1 / 6 / 99}{\text { Date }}
$$$$
\text { Cibstorlam }
$$$$
\text { Reviewer point of contact }
$$

\section{Reviewer}

C. D. Woll lam
8. Organization/Group

Technicat

Integration
9. Location/Phone

2753E/B104/200E

373-1587

11. CLOSED

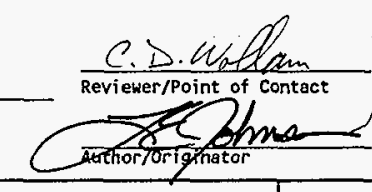

\begin{tabular}{|c|c|c|c|c|}
\hline $\begin{array}{l}12 . \\
\text { 1tem }\end{array}$ & $\begin{array}{l}\text { 13. Comment(s)/oiscrepancy(s) (Provide technical justification for the } \\
\text { comment and detai led recormendation of the action required to correct/ } \\
\text { resolve the discrepancy/problem indicated.) }\end{array}$ & $\begin{array}{l}14 . \\
\text { Hoid } \\
\text { Point } \\
\end{array}$ & 15. Disposition (Provide justification if Nor accepted.) & $\begin{array}{l}16 . \\
\text { status }\end{array}$ \\
\hline 1. & $\begin{array}{l}\text { Pg } 8-19 \text {, 2nd bullet }- \text { Fan(s) are operated on backup } \\
\text { steam power. In FY } 99 \text { the exhaust fanswill be tied } \\
\text { to diesel powered emergency generators. }\end{array}$ & & Accept. & \\
\hline 2. & $\begin{array}{l}\text { Pg 8-26, Ist bullet - Backup power is presently } \\
\text { steam. In } 99 \text { [there wi]l be a changeover]. }\end{array}$ & & Accept. & \\
\hline 3. & $\begin{array}{l}\text { Pg 8-35, 8.3.5, lst para: Is WHC-SD-SQA-TA-20006 } \\
\text { sti17 WHC? }\end{array}$ & & $\begin{array}{l}\text { Accept. The WHC document was replaced by } \\
\text { BWHC ZAP-000-009. }\end{array}$ & \\
\hline & & & & \\
\hline & & & & \\
\hline & & & & \\
\hline & & & & \\
\hline & & & & \\
\hline & & & & \\
\hline & & & & \\
\hline & & & & \\
\hline & & & & \\
\hline & & & & \\
\hline & & & & \\
\hline
\end{tabular}




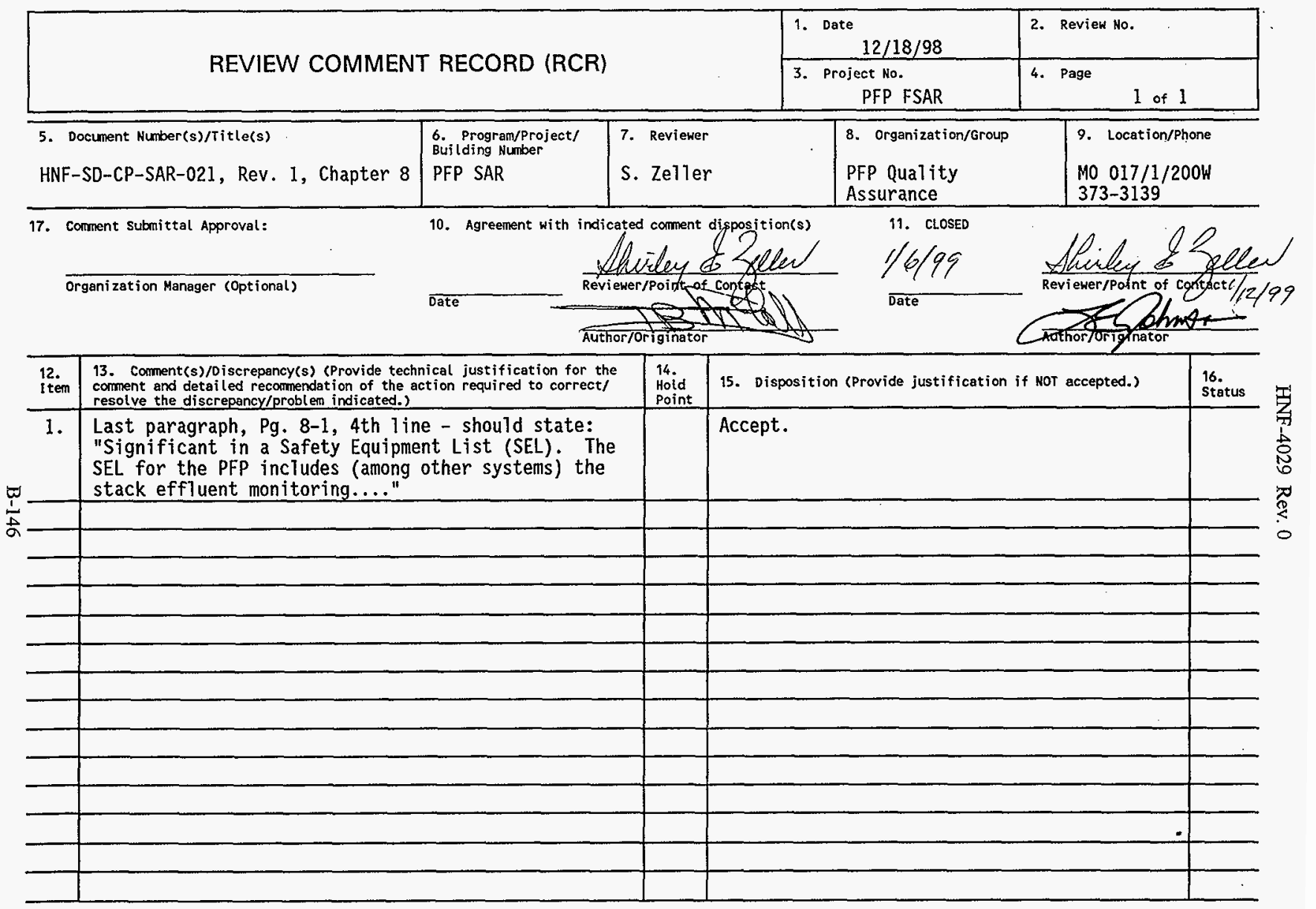




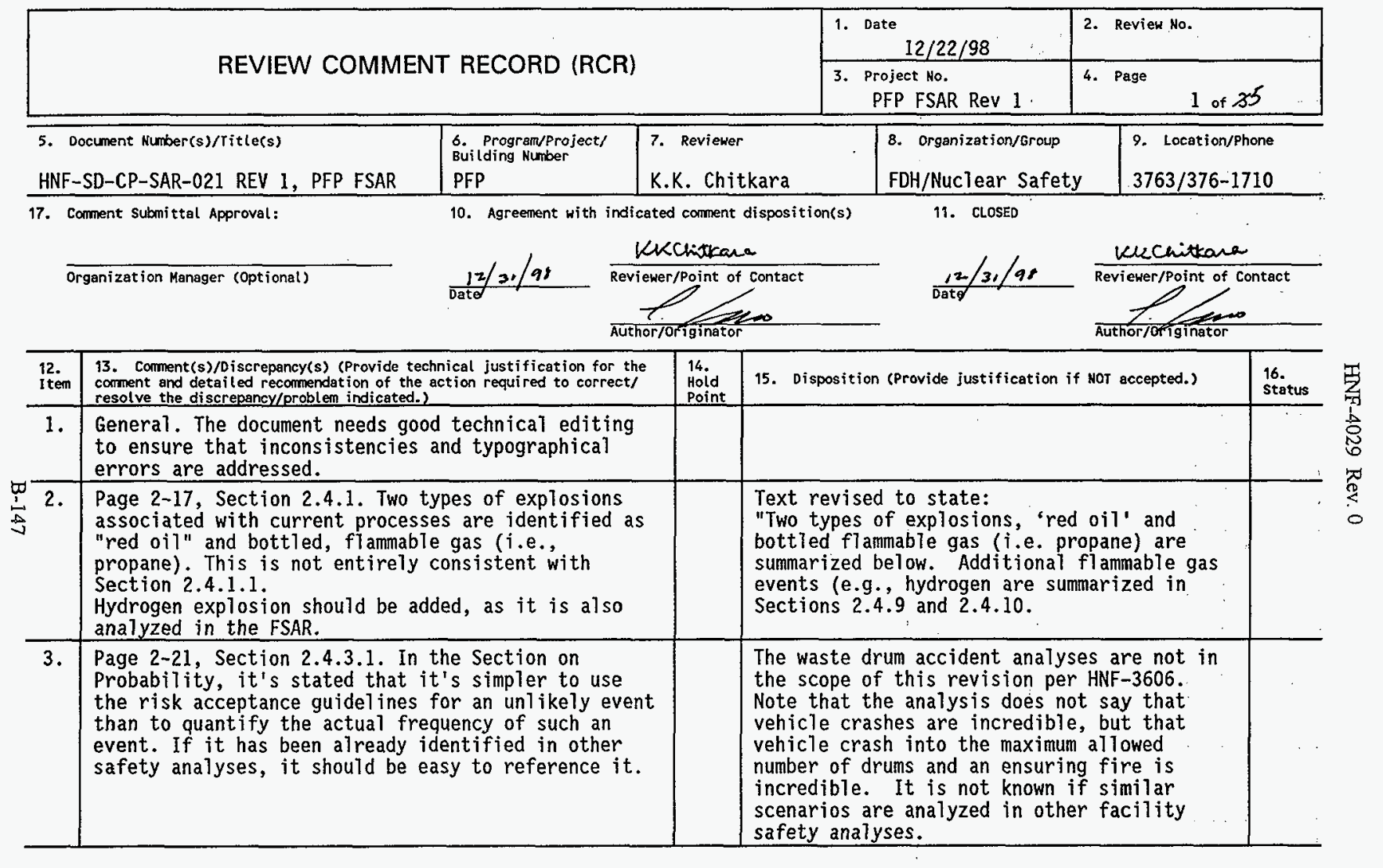




\begin{tabular}{|c|l|l|l|}
\hline \multirow{2}{*}{ REVIEW COMMENT RECORD (RCR) } & $\begin{array}{l}\text { 1. Date Review No. } \\
12 / 22 / 98\end{array}$ \\
\cline { 2 - 3 } & $\begin{array}{c}\text { 3. Project No. } \\
\text { PFP FSAR Rev } 1\end{array}$ & $\begin{array}{l}4 . \text { Page } \\
2 \text { of } \not^{5}\end{array}$ \\
\hline
\end{tabular}

\begin{tabular}{|c|c|c|c|c|}
\hline $\begin{array}{l}12 . \\
\text { Item }\end{array}$ & $\begin{array}{l}\text { 13. Comment(s)/Discrepancy(s) (Provide technical justification for the } \\
\text { comment and detailed recormendation of the action required to correct/ } \\
\text { resolve the discrepancy/problem indicated.) }\end{array}$ & $\begin{array}{l}14 . \\
\text { Hoid } \\
\text { Point }\end{array}$ & 15. Disposition (Provide justification if NOT accepted.) & $\begin{array}{l}16 . \\
\text { Status }\end{array}$ \\
\hline 4. & $\begin{array}{l}\text { Page } 2-26 \text {, Section } 2.4 .5 .3 .3 \text {. Please verify that the } \\
\text { frequency for concurrent criticality and fire is } \\
\text { consistent with the frequencies provided for } \\
\text { criticality and fire. }\end{array}$ & & $\begin{array}{l}\text { Frequency was verified to be consistent with } \\
\text { Section } 9.2 .4 .8 .3 \text {. The term "estimated" is } \\
\text { used to account for the fact that the } \\
\text { probability was not derived via calculation. } \\
\text { Note that the seismic induced fire and } \\
\text { criticality have different initiatars than } \\
\text { the non-seismic events. }\end{array}$ & $\ldots$ \\
\hline 5. & $\begin{array}{l}\text { Page 2-27, Section 2.4.5.4.3. Please clarify if the } \\
\text { doses are for the "ventilation" or "no ventilation" } \\
\text { case. }\end{array}$ & & $\begin{array}{l}\text { Revised lst sentence to clarify doses are } \\
\text { for the "no ventilation" case. }\end{array}$ & \\
\hline 6. & $\begin{array}{l}\text { Page 2-28, Section } 2.4 .6 \text {. If the event is identified } \\
\text { as an incredible event, why are consequences } \\
\text { compared to risk acceptance guidelines for an event } \\
\text { frequency of } 1 \mathrm{E}-02 / \mathrm{yr} \text {. Please clarify and revise the } \\
\text { text appropriately. }\end{array}$ & & $\begin{array}{l}\text { Stating that the consequences are acceptable } \\
\text { at 1F2 demonstrates the margin of risk } \ldots \ldots \\
\text { acceptance. }\end{array}$ & \\
\hline 7 & $\begin{array}{l}\text { Page 2-34, Section } 2.4 .10 .3 \text {. Present the } \\
\text { consequences for this accident, even if the are they } \\
\text { same as in the previous accident. }\end{array}$ & & Corrected per comment. & \\
\hline 8. & $\begin{array}{l}\text { Page } 2-35 \text {, Section } 2.4 .10 .4 \text {, Source Term. The stack } \\
\text { should be } 291-Z-1 \text {. }\end{array}$ & & Corrected per comment. & \\
\hline 9. & $\begin{array}{l}\text { Page 2-36, Section } 2.4 .10 .6 \text {, Source Term. The first } \\
\text { sentence has typo. errors, as instead of at, and } \\
10,000 \text { instead of } 10,000 \mathrm{~g} \text {. }\end{array}$ & & Corrected per comment. & \\
\hline 10. & $\begin{array}{l}\text { Page 2-36, Section } 2.5 \text {, Para. 1. Reword the } \\
\text { statement that the operation of the PFP over the } \\
\text { past } 45 \text { years indicates that it is fault tolerant. } \\
\text { The statement about the radiological impact should } \\
\text { be expanded to include toxicological and } \\
\text { environmental as well. }\end{array}$ & & Corrected per comment. & \\
\hline 11. & $\begin{array}{l}\text { Page F 2-3. Please ensure that Figure } 2-1 \text { has been } \\
\text { updated as per the note on Page F2-1. }\end{array}$ & & Figure revisions are complete. & \\
\hline
\end{tabular}




\begin{tabular}{|c|c|c|}
\hline & $\begin{array}{l}\text { 1. Date } 12 / 22 / 98\end{array}$ & 2. Review No. \\
\hline REVIEW COMMENT RECORD (RCR) & $\begin{array}{l}\text { 3. Project No. } \\
\text { PFP FSAR Rev } 1\end{array}$ & 3 of 35 \\
\hline
\end{tabular}

\begin{tabular}{|c|c|c|c|c|}
\hline $\begin{array}{l}12 . \\
\text { Item }\end{array}$ & $\begin{array}{l}\text { 13. Comment(s)/Discrepancy(s) (Provide technical justification for the } \\
\text { comment and detailed recommendation of the action required to correct/ } \\
\text { resolve the discrepancy/problem indicated.) }\end{array}$ & $\begin{array}{l}14 . \\
\text { Hoid } \\
\text { Point }\end{array}$ & 15. Disposition (Provide justification if NOT accepted.) & $\begin{array}{l}16 . \\
\text { Status }\end{array}$ \\
\hline 12. & $\begin{array}{l}\text { Page 9-301, Section } 9.2 .10 .1 .1 \text {, A hypothetical } \\
\text { pressure increase of } 0.4 \mathrm{psig} \text { is calculated. Please } \\
\text { identify the increase required to breach the } \\
\text { glovebox before concluding that there won't be a } \\
\text { breach. }\end{array}$ & & $\begin{array}{l}\text { Statement added: A pressure increase of } 0.4 \\
\text { psig is not expected to fail the glovebox } \\
\text { gloves. Walden (1980) suggest gloves fail } \\
\text { at an overpressure of } 0.6 \text { psi. } \\
\text { "Hoverver, a pressure increase of } 0.4 \mathrm{psig} \\
\text { could breach the glovebox via failed seal-in } \\
\text { ports." } \\
\text { Note however, that the analysis concludes } \\
\text { that the glovebox would not be pressurized } \\
\text { to the point that it is breached. }\end{array}$ & \\
\hline 13. & $\begin{array}{l}\text { Page 9-302, Section 9.2.10.2. The discussion in this } \\
\text { section is extremely detailed and at times hard to } \\
\text { understand. Suggest that salient features be covered } \\
\text { in this section and detailed information such as } \\
\text { polymer contaminants be included in an Appendix. }\end{array}$ & & $\begin{array}{l}\text { Removing a portion of the material and } \\
\text { placing it into an Appendix was considered. } \\
\text { Since the Accident Analys is Section of } \\
\text { chapter } 9 \text { is } 332 \text { pages long, removal of a } \\
\text { number of pages from this section to make it } \\
\text { easier for the reader when there are a } \\
\text { number of other sections of similiar } \\
\text { difficulity seemed unproductive. Instead, a } \\
\text { combination road-map/summary was written to } \\
\text { describe the flow of the section and the } \\
\text { salient points. }\end{array}$ & \\
\hline 14. & $\begin{array}{l}\text { Page 9-307, Section } 9.2 .10 .2 \text {, Last Para. If } 10 \mathrm{~g} \text { of } \\
\text { plastic is initially assumed for the analysis, } \\
\text { presenting a case of } 1 \mathrm{~g} \text { in the middle of the } \\
\text { discussion on the } 10 \mathrm{~g} \text { case should be avoided and } \\
\text { deleted. If it is to be retained, it should be } \\
\text { included as a part of the sensitivity analysis. This } \\
\text { problem exists again on Page } 9-313 \text {, when a } 2 \mathrm{~g} \text { case } \\
\text { is thrown in the middle of the } 10 \mathrm{~g} \text { case. }\end{array}$ & & $\begin{array}{l}\text { The small quantities of plastic were } \\
\text { analyzed for } 2 \text { reasons. The first was } \\
\text { because the result for the large quantities } \\
\text { was that the degradation products resulted } \\
\text { in concentrations of flammable gases above } \\
\text { the upper flammability limit. It was thought } \\
\text { that a smaller quantity of plastic might } \\
\text { result in a flammable gas concentration } \\
\text { within the limits. }\end{array}$ & \\
\hline
\end{tabular}




\begin{tabular}{|c|c|c|c|c|c|}
\hline \multirow{2}{*}{\multicolumn{3}{|c|}{ REVIEW COMMENT RECORD (RCR) }} & \multirow[b]{2}{*}{$\begin{array}{l}\text { 3. Project No. } \\
\text { PFP FSAR Rev } 1\end{array}$} & \multicolumn{2}{|l|}{ 2. Review №. } \\
\hline & & & & 4. Page & \\
\hline $\begin{array}{l}12 . \\
\text { item }\end{array}$ & $\begin{array}{l}\text { 13. Corment(s)/Discrepancy(s) (Provide technical justification for the } \\
\text { comment and detailed recormendation of the action required to correct/ } \\
\text { cesolve the discrepancy/problem indicated.) }\end{array}$ & $\begin{array}{l}14 . \\
\text { Hold } \\
\text { Point }\end{array}$ & \multicolumn{2}{|c|}{ 15. Disposition (Provide justification if NOT accepted.) } & $\begin{array}{l}16 . \\
\text { Status }\end{array}$ \\
\hline 15. & $\begin{array}{l}\text { Page 9-308, Section } 9.2 .10 .2 \text {. State the autoignition } \\
\text { temperature of benzene. Clarify the relevance of } 485 \\
\mathrm{C} \text { relative to the autoignition temperature of } \\
\text { benzene. } \\
\text { Delete the } 1 \mathrm{~g} \text { discussion as per the previous } \\
\text { comment. }\end{array}$ & & \multicolumn{2}{|c|}{$\begin{array}{l}\text { The autoignition temperature of benzene (of } \\
592 \mathrm{C} \text { ) was added to the section. Words were } \\
\text { also added that state that the calculation } \\
\text { was performed at } 485 \mathrm{C} \text { to be able to more } \\
\text { easily compare the results with the other } \\
\text { calculations. } \\
\text { The Ig discussion will remain in the section } \\
\text { for the reasons discussed in the response to } \\
\text { comments } 13 \text { and } 14 \text { above. }\end{array}$} & \\
\hline 16. & $\begin{array}{l}\text { Page } 9-310 \text {, Section } 9.2 .10 .2 \text {. The sentence in the } \\
\text { paragraph previous to the last paragraph, "Even if } \\
\text { the glovebox ventilation system should fail } \\
\text { is not complete. Please revise. }\end{array}$ & & \multicolumn{2}{|c|}{$\begin{array}{l}\text { The period was removed and replaced with a } \\
\text { comma as the next sentence is really part of } \\
\text { the second. the sentence now reads "Even if } \\
\text { the glovebox ventilation system.... gas is } \\
\text { coming out, the gas flow rate, its } \\
\text { temperature.... is judged to mix it well." }\end{array}$} & \\
\hline 17. & $\begin{array}{l}\text { Page 9-329, Section 9.2.10.3. Provide sections on } \\
\text { Probability and Conclusions. }\end{array}$ & & \multicolumn{2}{|c|}{$\begin{array}{l}\text { A probability header was added just above } \\
\text { the sentence starting as follows: "The } \\
\text { seismic deflagration is not considered } \\
\text { credible..." } \\
\text { The probability of the seismically induced } \\
\text { flash fire was estimated at } 1 E-5 \text { to 1E-6. } \\
\text { This was added to the probability section. A } \\
\text { consequence header was added to the section } \\
\text { just above the sentence starting with: "The } \\
\text { flash fire can result in radiant heat...." A } \\
\text { conclusion section was added that stated } \\
\text { that since the releases are insignificant, } \\
\text { the consequences of the seismically induced } \\
\text { flash fire are very much less than those of } \\
\text { a seismic event described in Section } 9.2,4 \text {. }\end{array}$} & \\
\hline
\end{tabular}




\begin{tabular}{|c|c|c|c|c|c|}
\hline \multirow{2}{*}{\multicolumn{3}{|c|}{ REVIEW COMMENT RECORD (RCR) }} & 1. Date $12 / 22 / 98$ & \multicolumn{2}{|l|}{ 2. Revien No. } \\
\hline & & & $\begin{array}{l}\text { 3. Project No. } \\
\text { PFP FSAR Rev } 1\end{array}$ & 4. Page & \\
\hline $\begin{array}{l}12 . \\
\text { Item }\end{array}$ & $\begin{array}{l}\text { 13. Corment(s)/Discrepancy(s) (Provide technical justification for the } \\
\text { comment and detailed recommendation of the action requi red to correct/ } \\
\text { resolve the discrepancy/problem indicated.) }\end{array}$ & $\begin{array}{l}\begin{array}{l}14 . \\
\text { Hoid } \\
\text { Point }\end{array} \\
\end{array}$ & \multicolumn{2}{|c|}{ 15. Disposition (Provide justification if HOT accepted.) } & $\begin{array}{l}16 . \\
\text { Status }\end{array}$ \\
\hline 18. & $\begin{array}{l}\text { Page 9-329, Section } 9.2 .10 .5 .1 \text {. Fire in the gTovebox } \\
\text { is addressed in Section } 9.2 .10 .4 \text { and not } 9.2 .10 .3 \text {. } \\
\text { Please verify and revise. }\end{array}$ & & \multicolumn{2}{|l|}{ Corrected per comment. } & \\
\hline 19. & $\begin{array}{l}\text { Page } 9-330 \text {, Section } 9.2 .10 .5,4.1 . \text { Para. } 3 \text {. The } X / Q \\
\text { for the offsite case should be } 5.73 \mathrm{E}-06 \text { and not } \\
5.63 \mathrm{E}-06 \mathrm{~s} / \mathrm{m} 3 \text {. Please revise. }\end{array}$ & & \multicolumn{2}{|l|}{ Corrected per comment. } & \\
\hline
\end{tabular}




\begin{tabular}{|c|c|c|}
\hline \multirow{2}{*}{ REVIEW COMMENT RECORD (RCR) } & $\begin{array}{l}\text { 1. Date } \\
12 / 22 / 98 \\
\end{array}$ & $\begin{array}{r}\text { 2. Review No. } \\
\text { jpk.chs }\end{array}$ \\
\hline & $\begin{array}{l}\text { 3. Project No. } \\
\text { PFPFSAR }\end{array}$ & 4. Page \\
\hline
\end{tabular}

\begin{tabular}{|c|c|c|c|c|}
\hline 5. Document Number(s)/Titte(s) & $\begin{array}{l}\text { 6. Program/Project/ } \\
\text { Building Number }\end{array}$ & 7. Reviewer & 8. Organization/Group & 9. Location/Phone \\
\hline $\begin{array}{l}\text { WHC-SD-CP-SAR-021 Draft Rev. } 1 \\
\text { Plutonium Finishing PI ant Final } \\
\text { Safety Analysis Report Chapter } 9\end{array}$ & $\begin{array}{l}\text { PFP } \\
\text { Authorization } \\
\text { Basis }\end{array}$ & J.P. King & PFP Ops $/ 15310$ & $270-z / 373-5194$ \\
\hline
\end{tabular}
Safety Analys is Report Chapter 9

17. Comment submittal Approval:

Organization Manager (Optional)
10. Agreement with indicated coment dipposition(s)

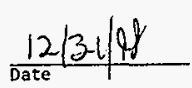
Reviewer/Point of contact
11. CLOSEO

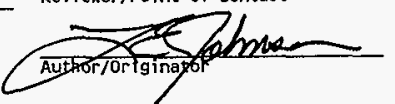

$12(3.195$

Date

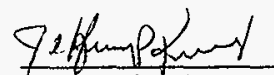
Reviewer/Point of contact

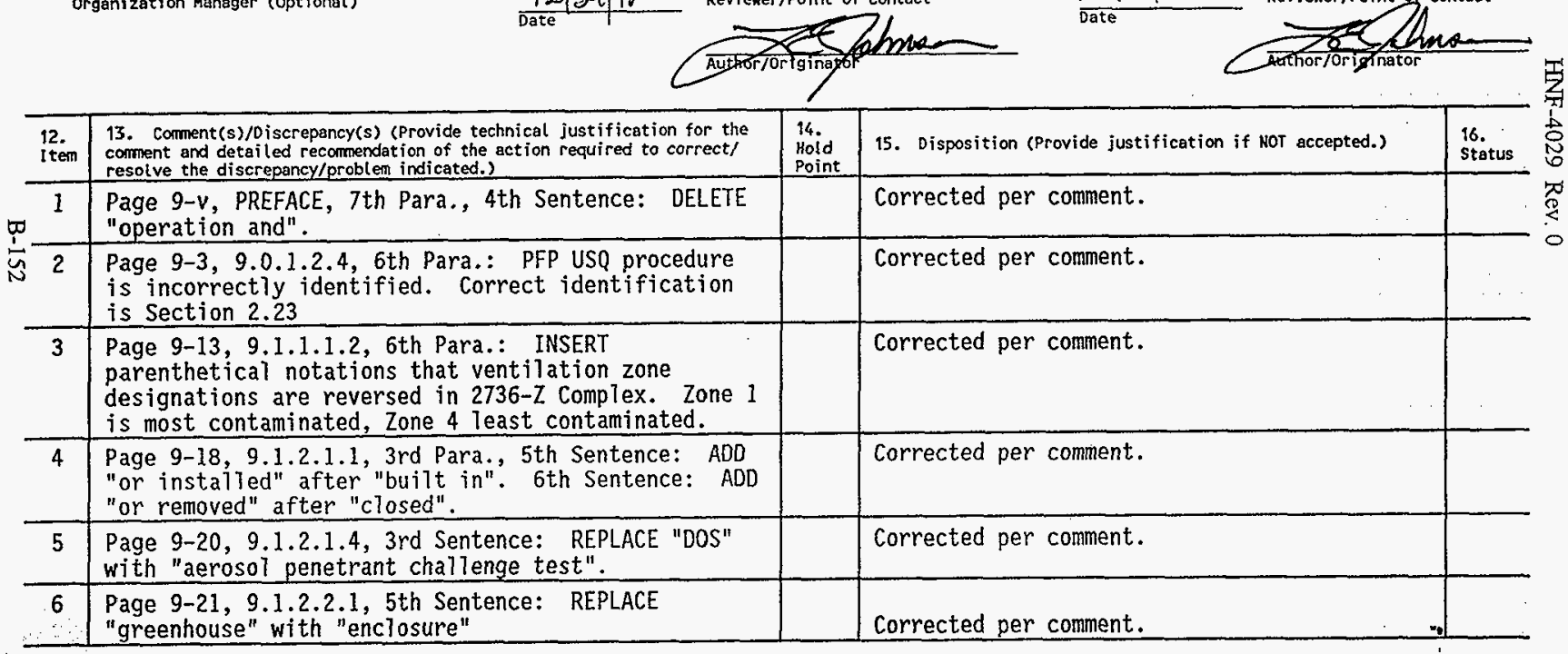




\begin{tabular}{|c|c|c|}
\hline & $\begin{array}{l}\text { 1. Date } \\
12 / 22 / 98\end{array}$ & $\begin{array}{l}\text { 2. Review No. } \\
\text { jpk.ch9 }\end{array}$ \\
\hline REVIEW COMMENT RECORD (RCR) & $\begin{array}{l}\text { 3. Project No. } \\
\text { PFPFSAR }\end{array}$ & $\begin{array}{l}\text { 4. Page } 2 \text { of } 9 \\
\end{array}$ \\
\hline
\end{tabular}

\begin{tabular}{|c|c|c|c|c|}
\hline $\begin{array}{l}12 . \\
\text { item }\end{array}$ & $\begin{array}{l}\text { 13. Comment(s)/Discrepancy(s) (Provide technical justification for the } \\
\text { compent and detai led recommendation of the action required to correct/ } \\
\text { resolve the discrepaney(problem indicated.) }\end{array}$ & $\begin{array}{l}14 . \\
\text { Hoid } \\
\text { Point } \\
\end{array}$ & 15. Disposition (Provide justification if Nor accepted.) & $\begin{array}{l}\text { 16. } \\
\text { Status }\end{array}$ \\
\hline 7 & $\begin{array}{l}\text { Page 9-23, 9.1.3.1.1, 5th Para.: The paragraph is } \\
\text { discussing a study that was done previousiy. } \\
\text { Therefore, REWORD the paragraph using past tense, } \\
\text { e.g. "were" instead of "are", "was" instead of "is". }\end{array}$ & & $\begin{array}{l}\text { Text is referring to seal-out, load-out } \\
\text { activities, not a completed study of such } \\
\text { activities. }\end{array}$ & \\
\hline 8 & $\begin{array}{l}\text { Page 9-25, 9.1.3.2.1, 2nd Para., 4th Sentence: } \\
\text { CHANGE to "Upon actuation, facility workers are } \\
\text { trained to promptly evacuate the affected air } \\
\text { space." DELETE "while holding their breath" }\end{array}$ & & Corrected per comment. & \\
\hline 9 & $\begin{array}{l}\text { Page 9-25, 9.1.3.2.1, 3rd Para., 4th Sentence: } \\
\text { INSERT "or quickiy drop to the floor" between } \\
\text { "airborne" and "then". }\end{array}$ & & Corrected per comment. & \\
\hline 10 & $\begin{array}{l}\text { Page 9-33, 9.1.4.2.1, 5th Para., 2nd Sentence: } \\
\text { CHANGE to "Upon actuation, facility workers are } \\
\text { trained to promptly evacuate the affected air } \\
\text { space." DELETE "while holding their breath" }\end{array}$ & & Corrected per comment. & \\
\hline 11 & $\begin{array}{l}\text { Page 9-33, } 9.1 .4 .2 .2,5 \text { th Sentence: CHANGE } \\
\text { "monitoring" to "survey" }\end{array}$ & & Corrected per comment. & \\
\hline 12 & $\begin{array}{l}\text { Page 9-40, 9.1.5A.1.3, 3rd Sentence: CHANGE to "The } \\
\text { power operator immediately notifies the Shift } \\
\text { Manager/Building Emergency Director in Room 104." }\end{array}$ & & Corrected per comment. & \\
\hline 13 & $\begin{array}{l}\text { Page 9-40 \& 9-41, 9.1.5A.3, 2nd and 3rd Sentences: } \\
\text { Should be past tense; "was" instead of "is". }\end{array}$ & & Corrected per comment. & \\
\hline 14 & $\begin{array}{l}\text { Page 9-43, 9.1.5B, 3rd Para.: DELETE ", and due to } \\
\text { the generaliy moist conditions" (see next comment } \\
\text { below) }\end{array}$ & & Corrected per comment. & \\
\hline
\end{tabular}




\begin{tabular}{|l|l|l|l|}
\hline \multirow{2}{*}{ REVIEW COMMENT RECORD (RCR) } & $\begin{array}{l}\text { 1. Date Review No. } \\
\text { jpk. ch9 }\end{array}$ & $\begin{array}{l}12 / 22 / 98 \\
\text { 3. Project No. } \\
\text { PFPFSAR }\end{array}$ & $\begin{array}{l}4 . \text { Page } \\
3\end{array}$ \\
\hline
\end{tabular}

\begin{tabular}{|c|c|c|c|c|}
\hline $\begin{array}{l}12 . \\
\text { I tem }\end{array}$ & $\begin{array}{l}\text { 13. Corment(s)/Discrepancy(s) (Provide technical justification for the } \\
\text { corment and detaited recormendation of the action required to correct/ } \\
\text { resolve the discrepancy/problem indicated.2 }\end{array}$ & $\begin{array}{l}14 . \\
\text { Hoid } \\
\text { Point }\end{array}$ & 15. Disposition (Provide justification if NOT accepted.) & $\begin{array}{l}16 . \\
\text { Status }\end{array}$ \\
\hline 15 & $\begin{array}{l}\text { Page 9-43, 9.1.5B, 4th Para.: Can not take credit } \\
\text { for air being exhausted from "wet" gloveboxes. PRF } \\
\text { has been dried out for several years. SUGGEST } \\
\text { changing to "radionuclides present in the PRF canyon } \\
\text { and gloveboxes were deposited in the form of } \\
\text { residues or sludges associated with wet processes } \\
\text { and are not easily resuspended. In addition, PRF is } \\
\text { an inactive facility, thus significant amounts of } \\
\text { contamination are not being disturbed and released } \\
\text { to the ventilation system." }\end{array}$ & & Corrected per comment. & \\
\hline 16 & $\begin{array}{l}\text { Page 9-55, 9.1.7A.1.2.4, 10th Para., 3rd Sentence: } \\
\text { CHANGE "HS" to "Hg". 4th Sentence, ADD "and process } \\
\text { vessels" after "gloveboxes". }\end{array}$ & & Corrected per comment. & \\
\hline 17 & $\begin{array}{l}\text { Page 9-57, 9.1.7A.2.3, Ist Sentence: CHANGE "fans" } \\
\text { after "emergency electric-motor driven exhaust" to } \\
\text { "fan" (singular, only one remains running) }\end{array}$ & & Corrected per comment. & \\
\hline 18 & $\begin{array}{l}\text { Page 9-71, 9.1.7B.2.3, 2nd Sentence: Same comment } \\
\text { as immediately above. CHANGE "emergency exhaust } \\
\text { fans" to "fan" (singuTar). }\end{array}$ & & Corrected per comment. & \\
\hline 19 & $\begin{array}{l}\text { Page 9-85, 9.1.7F.2.4, 5th Sentence: Same comment } \\
\text { as immediately above. CHANGE "emergency exhaust } \\
\text { fans" to "fan" (singuiar). }\end{array}$ & & Corrected per comment. & \\
\hline 20 & $\begin{array}{l}\text { Page 9-86, 9.1.7F.5.2, 3rd Sentence: DELETE } \\
\text { "engineered" }\end{array}$ & & Corrected per comment. & \\
\hline 21 & $\begin{array}{l}\text { Page 9-87, 9.1.8, 5th Sentence: CHANGE "bring" to } \\
\text { "maintain" }\end{array}$ & & Corrected per comment. & \\
\hline 22 & $\begin{array}{l}\text { Page 9-88, 9.1.8.2.1, 4th Sentence: DELETE "125-Vdc } \\
\text { batteries (see Section } 5.4 \text { ) that have been tested } \\
\text { under fuT load for over } 2 \mathrm{~h} . " \text { REPLACE with } \\
\text { "facility emergency lights". }\end{array}$ & & Corrected per comment. & \\
\hline
\end{tabular}




\begin{tabular}{|c|c|c|}
\hline \multirow{2}{*}{ REVIEW COMMENT RECORD (RCR) } & $\begin{array}{l}\text { 1. Date } \\
12 / 22 / 98 \\
\end{array}$ & $\begin{array}{r}\text { 2. Revien No. } \\
\text { jpk.ch9 }\end{array}$ \\
\hline & $\begin{array}{l}\text { 3. Project No. } \\
\text { PFPFSAR }\end{array}$ & 4. Page 4 of 9 \\
\hline
\end{tabular}

\begin{tabular}{|c|c|c|c|c|}
\hline 12. & $\begin{array}{l}\text { 13. Comment(s)/Discrepancy(s) (Provide technical justification for the } \\
\text { comment and detailed recormendation of the action required to correct/ } \\
\text { resolve the discrepancy/problem indjcated.) }\end{array}$ & $\begin{array}{l}14 . \\
\text { Mold } \\
\text { Point }\end{array}$ & 15. Disposition (Provide justification if nOT accepted.) & $\begin{array}{l}16 . \\
\text { Status }\end{array}$ \\
\hline 23 & $\begin{array}{l}\text { Page 9-93, 9.1.8.4, 4th Sentence: CHANGE to "The } \\
\text { two gloveboxes examined in this section previous7y } \\
\text { contained ...". 5th Sentence: CHANGE "are" to } \\
\text { "were". 7th Sentence: INSERT "(empty and not in } \\
\text { service)" between "HC-4" and "is". }\end{array}$ & & Corrected per comment. & \\
\hline 24 & $\begin{array}{l}\text { Page 9-128, 9.2.2D.1, 6th Para., 2nd Bullet, 3rd } \\
\text { Sentence: REPLACE WHC-CM-4-29 reference with } \\
\text { current HNF-PRO }\end{array}$ & & $\begin{array}{l}\text { Replaced with reference to HNF-PROs } 334 \text { \& } \\
537 \text {. }\end{array}$ & \\
\hline 25 & $\begin{array}{l}\text { Page 9-139, 9.2.3 4th Sentence: CORRECT typo, } \\
\text { should be "2736- } Z \text { " }\end{array}$ & & Corrected per comment. & \\
\hline 26 & $\begin{array}{l}\text { Page } 9-140,9.2 .3 .1 .3 .1 \text { : Since PRF is inactive and } \\
\text { not authorized for operation, discussion HSW CAW CXP } \\
\text { and cUU should be past tense. }\end{array}$ & & $\begin{array}{l}\text { Sentence added: Note that the PRF is } \\
\text { inactive and that High Salt Waste (HSW) is } \\
\text { no longer generated. }\end{array}$ & \\
\hline 27 & $\begin{array}{l}\text { Page 9-141, 9.2.3.1.3.2: Same comment as } \\
\text { immediately above. }\end{array}$ & & See response to Comment \#26. & \\
\hline 28 & $\begin{array}{l}\text { Page } 9-147,9.2 .3 .4 .3,3 \text { rd and } 4 \text { th Para.: Same } \\
\text { comment as immediately above. }\end{array}$ & & See response to Comment $\# 28$. & \\
\hline 29 & $\begin{array}{l}\text { Page 9-157,9.2.4.0.2, 2nd Para., 2nd Sentence: } \\
\text { CHANGE "WHC" to "PHMC". In addition, it should be } \\
\text { verified that the HNF-PRO RAGs have not changed. }\end{array}$ & & $\begin{array}{l}\text { WHC deleted, no reference made to HNF-PROs. } \\
\text { Per HNF- } 3606 \text { we are using the old RAGs. }\end{array}$ & \\
\hline 30 & $\begin{array}{l}\text { Page 9-166, 9.2.4.2.1D, 2nd Sentence: CHANGE to } \\
\text { "Neither glovebox are presently in use." }\end{array}$ & & Corrected per comment. & \\
\hline
\end{tabular}




\begin{tabular}{|l|l|c|}
\hline \multirow{2}{*}{ REVIEW COMMENT RECORD (RCR) } & $\begin{array}{l}\text { 1. Date Review No. } \\
\text { jpk.ch9 }\end{array}$ \\
\cline { 2 - 3 } & $\begin{array}{c}\text { 3. Project No. } \\
\text { PFPFSAR }\end{array}$ & $\begin{array}{c}\text { 4. Page } \\
5 \text { of } 9\end{array}$ \\
\hline
\end{tabular}

\begin{tabular}{|c|c|c|c|c|}
\hline $\begin{array}{l}12 . \\
\text { item }\end{array}$ & $\begin{array}{l}\text { 13. Comment(s)/Discrepancy(s) (Provide technical justification for the } \\
\text { comment and detai led recormendation of the action required to correct/ } \\
\text { resolve the discrepancy/problem indicated.) }\end{array}$ & $\begin{array}{l}14 . \\
\text { Hold } \\
\text { Point }\end{array}$ & 15. Disposition (Provide justification if NOT accepted.) & $\begin{array}{l}16 . \\
\text { Status }\end{array}$ \\
\hline 31 & $\begin{array}{l}\text { Page 9-171, 9.2.4.2.1X, 2nd Sentence: I have a real } \\
\text { problem with this one and with Marusich's } \\
\text { assumption. H-9A contains a nominal } 1515 \text { grams of } \\
\text { Pu, HA-10 contains a nominal } 541 \text { grams. Neither } \\
\text { were "thoroughiy cleaned out", nor do they contain } \\
\text { "wet nondispersible material". Is this a Discovery } \\
\text { of an incorrect assumption used in the AB? (IAW } \\
5480.21) \text { Therefore, suggest we try to make the same } \\
\text { argument that is used for 242-Z (9.2.4.2.7) and that } \\
\text { I have suggested be used for PRF above. }\end{array}$ & & $\begin{array}{l}\text { The last sentence in Section 9.2.4.2.1X was } \\
\text { replaced with the following: } \\
\text { The old RMA line is inactive. The } \\
\text { gloveboxes were cleaned in preparation of } \\
\text { deactivation and decommissioning activities. } \\
\text { As with the } 242-z \text { facility discussed in } \\
\text { Section } 9.2 .4 .2 .7 \text {, the residual material in } \\
\text { the old RMA line is expected to be contained } \\
\text { within process equipment and to be tightly } \\
\text { adhered to surfaces. The releases from the } \\
\text { gloveboxes in this room would be small in } \\
\text { comparison to the releases from active areas. } \\
\text { of the plant and are not included in the } \\
\text { dose consequence analysis for the seismic } \\
\text { event. }\end{array}$ & \\
\hline 32 & $\begin{array}{l}\text { Page 9-176, } 9.2 .4 .2 .11 \text {, 4th Para. and Bullets: The } \\
\text { purpose of this paragraph is confusing. Sentence } 1 \\
\text { refers to active gloveboxes, yet the bulletized } 1 \text { ist } \\
\text { contains inactive gloveboxes, e.g., MT-5, MT-6, HC- } \\
6 \text {, GB-522, while inactive gloveboxes H-9A or HA-10 } \\
\text { (greater than a MCM) are not listed, and GB-188-1 } \\
\text { (prototype calciner) is not listed. There may be } \\
\text { more that I have not listed, but this paragraph } \\
\text { needs to be fixed. }\end{array}$ & & $\begin{array}{l}\text { The paragraph has been revised so that it } \\
\text { doesn't imply that the subsequent list of } \\
\text { gloveboxes or plant areas are all active. } \\
\text { In the bulletized list, "(inactive)" was } \\
\text { added after each glovebox that is now } \\
\text { inactive (HC-6, MT-5, Mt-6). The } \\
\text { discussions in the sections following the } \\
\text { list identify the inactive gloveboxes as } \\
\text { well. } \\
\text { Statement added that the above identified } \\
\text { locations are analyzed in the following } \\
\text { subsections. } \\
\text { The potential for seismic induced } \\
\text { criticalities in GB-188-1, or HA-10 will } \\
\text { need to be addressed in the FSAR revision. }\end{array}$ & \\
\hline
\end{tabular}




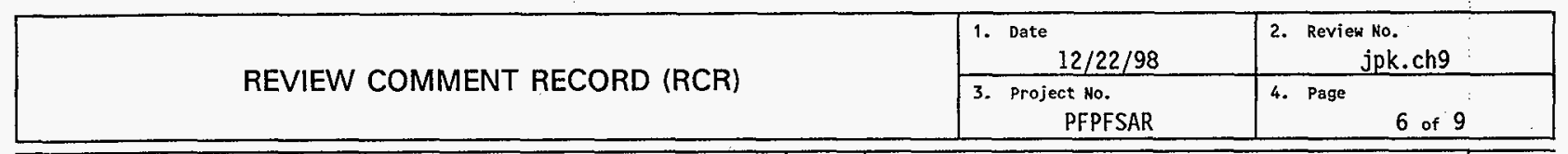

\begin{tabular}{|c|c|c|c|c|}
\hline \begin{tabular}{l|l}
12. \\
Iten
\end{tabular} & $\begin{array}{l}\text { 13. Comment(s)/Discrepancy/(s) (Provide technical justification for the } \\
\text { corment and detai led recomendation of the action required to correct/ } \\
\text { resolve the discrepancy/problem indicated.) }\end{array}$ & $\begin{array}{l}14 . \\
\text { Hold } \\
\text { Point }\end{array}$ & 15. Disposition (Provide justification if NOT accepted.) & $\begin{array}{l}16 . \\
\text { Status } \\
\end{array}$ \\
\hline 33 & $\begin{array}{l}\text { Page 9-179, 9.2.4.2.11.E, 6th Para., ADD "Processes } \\
\text { associated with } \mathrm{HC}-4 \text { are currently inactive" to end } \\
\text { of paragraph. }\end{array}$ & & $\begin{array}{l}\text { Sentence added to end of paragraph as } \\
\text { suggested. }\end{array}$ & \\
\hline 34 & $\begin{array}{l}\text { Page 9-182, 9.2.4.2.11.J, Ist Sentence: CHANGE to } \\
\text { "Processes associated with glovebox HC-7 are } \\
\text { currently inactive". }\end{array}$ & & Change made. & \\
\hline 35 & $\begin{array}{l}\text { Page 9-208, 9.2.4.6.3.1.U, 2nd Sentence: DELETE. } \\
\text { HC-1A does not exist, was an error from Rev. } 0 \text {. We } \\
\text { will be reactivating HA-22B. Existing 3rd Sentence: } \\
\text { CHANGE to "Conveyors HA-28, HC-4, and Glovebox HA- } \\
22 \mathrm{~B} \text { are normally empty." }\end{array}$ & & $\begin{array}{l}\text { Deleted both references to } \mathrm{HC}-1 \mathrm{~A} \text {. Revised } \\
\text { 3rd sentence as suggested. }\end{array}$ & \\
\hline 36 & $\begin{array}{l}\text { Page } 9-226,9.2 .4 .6 .3 .2 . C . d: \text { ADD after equation: } \\
\text { "Room } 27 \text { maintenance glovebox and she?f storage have } \\
\text { been declared inactive since the above analys is was } \\
\text { originally performed. The release estimate is } \\
\text { retained for conservatism, pending a future update } \\
\text { to the entire seismic accident analysis." }\end{array}$ & & Change made. & \\
\hline 37 & $\begin{array}{l}\text { Page 9-255, 9.2.6.2, 2nd Para.: DELETE 3rd Sentence } \\
\text { regarding scuppers and french drains. Their are no } \\
\text { french drains in the tunnels. 3rd Para., 2nd } \\
\text { Sentence: DELETE "both" and "and in the PRF control } \\
\text { room". }\end{array}$ & & Corrected per comment. & \\
\hline 38 & $\begin{array}{l}\text { Page } 9-347,9.3 .5 .4 \text {, } 5 \text { th Para.: REPLACE WHC-CM-4-46 } \\
\text { reference with current HNF-PRO procedure. }\end{array}$ & & Reference to WHC deleted. & \\
\hline 39 & $\begin{array}{l}\text { Page } 9-351,9.1 \text { lst Sentence: REPLACE WHC-CM-4-46 } \\
\text { reference with current HNF-PRO or insert (superseded } \\
\text { by HNF-PRO-) }\end{array}$ & & Intro paragraph deleted. & \\
\hline 40 & $\begin{array}{l}\text { Page } 9-355,9.4 .2 .1: \text { REPLACE WHC-CM-4-46 references } \\
\text { with current HNF-PRO procedure. }\end{array}$ & & Reference to WHC deleted. & \\
\hline
\end{tabular}




\begin{tabular}{|c|l|l|l|}
\hline \multirow{2}{*}{ REVIEW COMMENT RECORD (RCR) } & $\begin{array}{l}\text { 1. Date } \\
12 / 22 / 98\end{array}$ & $\begin{array}{c}\text { Review No. } \\
j p k . c h 9\end{array}$ \\
\cline { 2 - 3 } & $\begin{array}{c}3 . \text { Project No. } \\
\text { PFPFSAR }\end{array}$ & $\begin{array}{c}4 . \quad \text { Page } \\
7 \text { of } 9 .\end{array}$ \\
\hline
\end{tabular}

\begin{tabular}{|c|c|c|c|c|}
\hline $\begin{array}{l}12 . \\
\text { Item }\end{array}$ & $\begin{array}{l}\text { 13. Comment( }(s) / D \text { iscrepancy(s) (Provide technical justification for the } \\
\text { comment and detai led recommendation of the action required to correct/ } \\
\text { resolve the discrepancy/problem indicated.) }\end{array}$ & $\begin{array}{l}14 . \\
\text { Hold } \\
\text { Point } \\
\end{array}$ & 15. Disposition (Provide justification if NOT accepted.) & $\begin{array}{l}16 . \\
\text { status }\end{array}$ \\
\hline 41 & $\begin{array}{l}\text { Page T9-29, Tables } 9-25 \text { and 9-26: CHANGE Tables 9- } \\
25 \text { and }-26 \text { Tistings and values back to as they } \\
\text { appear in Rev. } 0 \text {, Table } 9.2 .4-1 \text {, with the exception } \\
\text { of deletion of Glovebox HC-1A, Room } 235-B \text {, which } \\
\text { does not physically exist. ANNOTATE that the table } \\
\text { reflects those values used in the original } 1994 \\
\text { seismic accident analysis. This table can not be } \\
\text { updated until the entire seismic analysis, including } \\
\text { OSR LCO and AC, is redore. Reason for this is that } \\
\text { it is the existing Table } 9.2 .4-1 \text {, as it was } \\
\text { incorporated from WHC-SD-CP-SAD-002, is the BASES } \\
\text { for OSR LCO } 3.3 .1 \text {. LCO } 3.3 .1 \text { BASES states: } \\
\text { "The plutonium quantities which make up the mass } \\
\text { limits for the physical areas of the facility are } \\
\text { derived from the values used in WHC-SD-CP-SAD-002 } \\
\text { "Safety Assessment for PFP Inventory Sensitivity of } \\
\text { the Seismic Event" as the inventory potentially } \\
\text { present in each glovebox. The values in individual } \\
\text { gloveboxes in each area were summed to get the } \\
\text { totals shown in the LCO. In addition, AC } 5.22 \text {, } \\
\text { Plutonium Inventory, provides an administrative } \\
\text { program which ensures the inventory of every } \\
\text { glovebox analyzed in wHC-SD-CP-SAD-002 is maintained } \\
\text { less than or equal to the value assumed in the } \\
\text { analysis." }\end{array}$ & & $\begin{array}{l}\text { A paragraph was placed at the beginning of } \\
\text { Section } 9.2 .4 \text { stating that the basis of LCO } \\
3.3 .1 \text { and AC } 5.22 \text { waS SAD-002 as } \\
\text { incorporated in SAR-021, Rev. } 0 \text {. It further } \\
\text { states that the results of SAD-002 was an } \\
\text { onsite dose of } 20 \text { rem. The paragraph then } \\
\text { goes on to say that the analysis below is } \\
\text { based on present CPS limits and glovebox } \\
\text { activation status. Since a number of } \\
\text { gloveboxes have been inactivated, the onsite } \\
\text { dose is only 8-9 rem. A new Table (Table } 9- \\
61) \text { was added showing the CPS limits for all } \\
\text { of the gloveboxes per SAD-002. }\end{array}$ & \\
\hline
\end{tabular}




\begin{tabular}{|l|l|l|l|}
\hline \multirow{2}{*}{ REVIEW COMMENT RECORD (RCR) } & $\begin{array}{l}\text { 1. Date } \\
12 / 22 / 98\end{array}$ \\
\cline { 2 - 3 } & $\begin{array}{c}\text { 3. Project No. Review No. } \\
\text { PFPFSAR }\end{array}$ & $\begin{array}{l}\text { jpk. ch9 Page } \\
8 \text { of 9 }\end{array}$ \\
\hline
\end{tabular}

\begin{tabular}{|c|c|c|c|c|}
\hline $\begin{array}{l}12 . \\
\text { item }\end{array}$ & $\begin{array}{l}\text { 13. Comment(s)/oiscrepancy(s) (Provide technicat justification for the } \\
\text { comment and detailed recommendation of the action required to correct/ } \\
\text { resolve the discrepancy/problem indicated.) }\end{array}$ & $\begin{array}{l}14 . \\
\text { Hoid } \\
\text { Point }\end{array}$ & 15. Disposition (Provide justification if Not accepted.) & $\begin{array}{l}\text { 16. } \\
\text { Status }\end{array}$ \\
\hline & 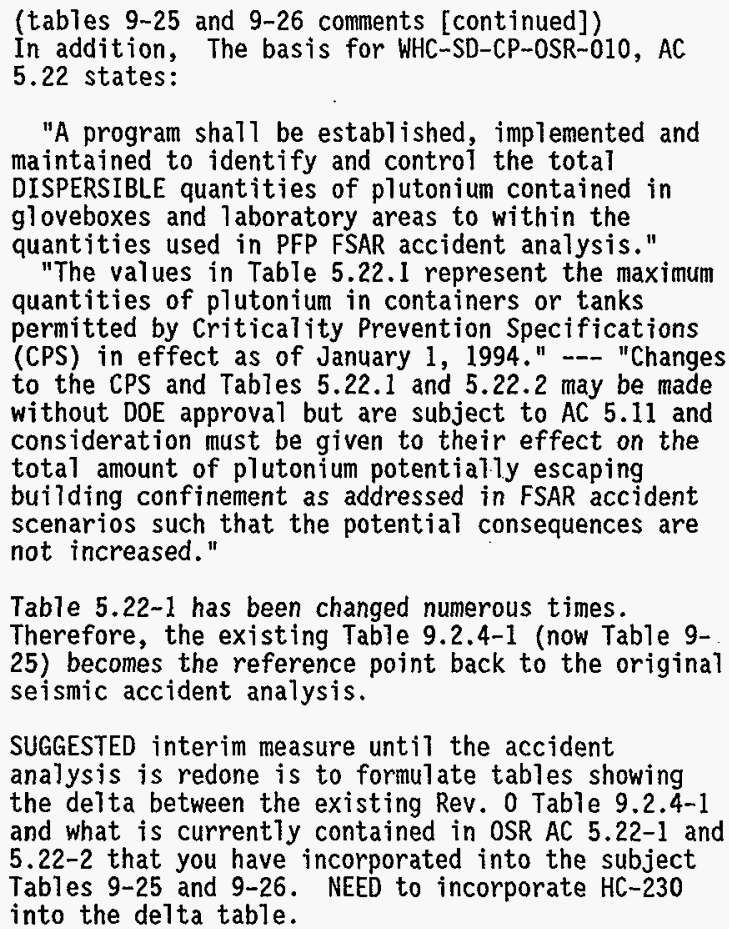 & & & \\
\hline
\end{tabular}




\begin{tabular}{|l|l|l|}
\hline \multirow{2}{*}{ REVIEW COMMENT RECORD (RCR) } & $\begin{array}{l}\text { 1. Date } \\
12 / 22 / 98\end{array}$ & $\begin{array}{l}\text { Review No. } \\
\text { jpk. ch9 }\end{array}$ \\
\cline { 2 - 3 } & $\begin{array}{l}\text { 3. Project No. } \\
\text { PFPFSAR }\end{array}$ \\
\hline
\end{tabular}

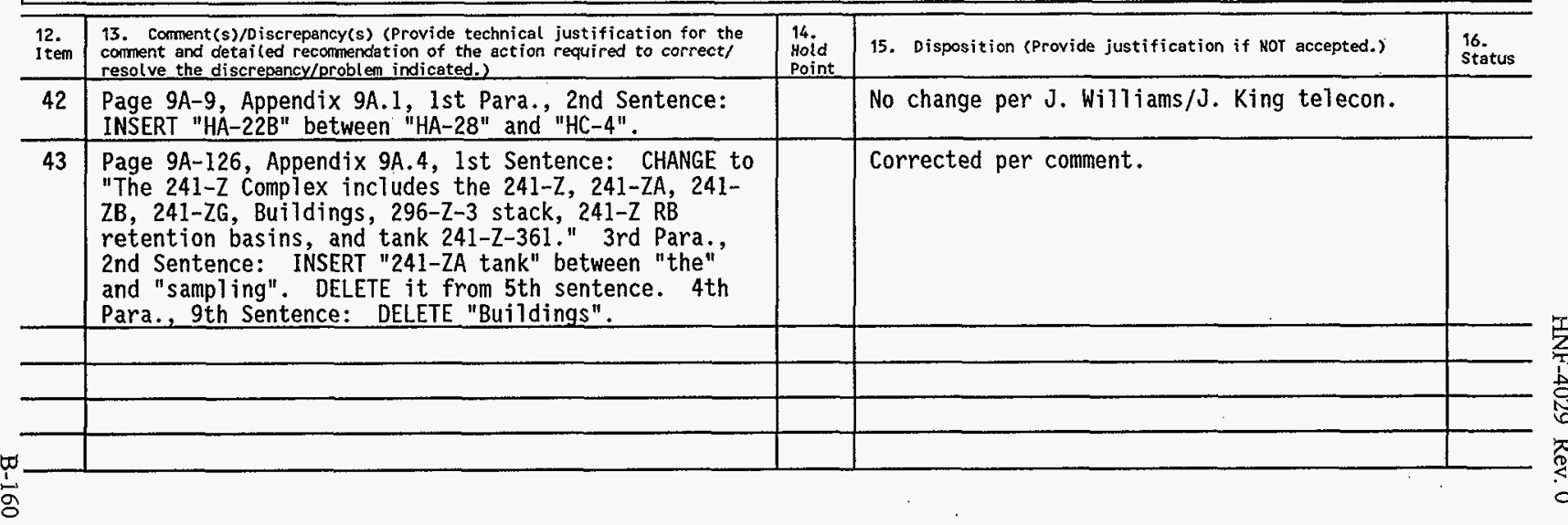


HNF-4029 Rev. 0

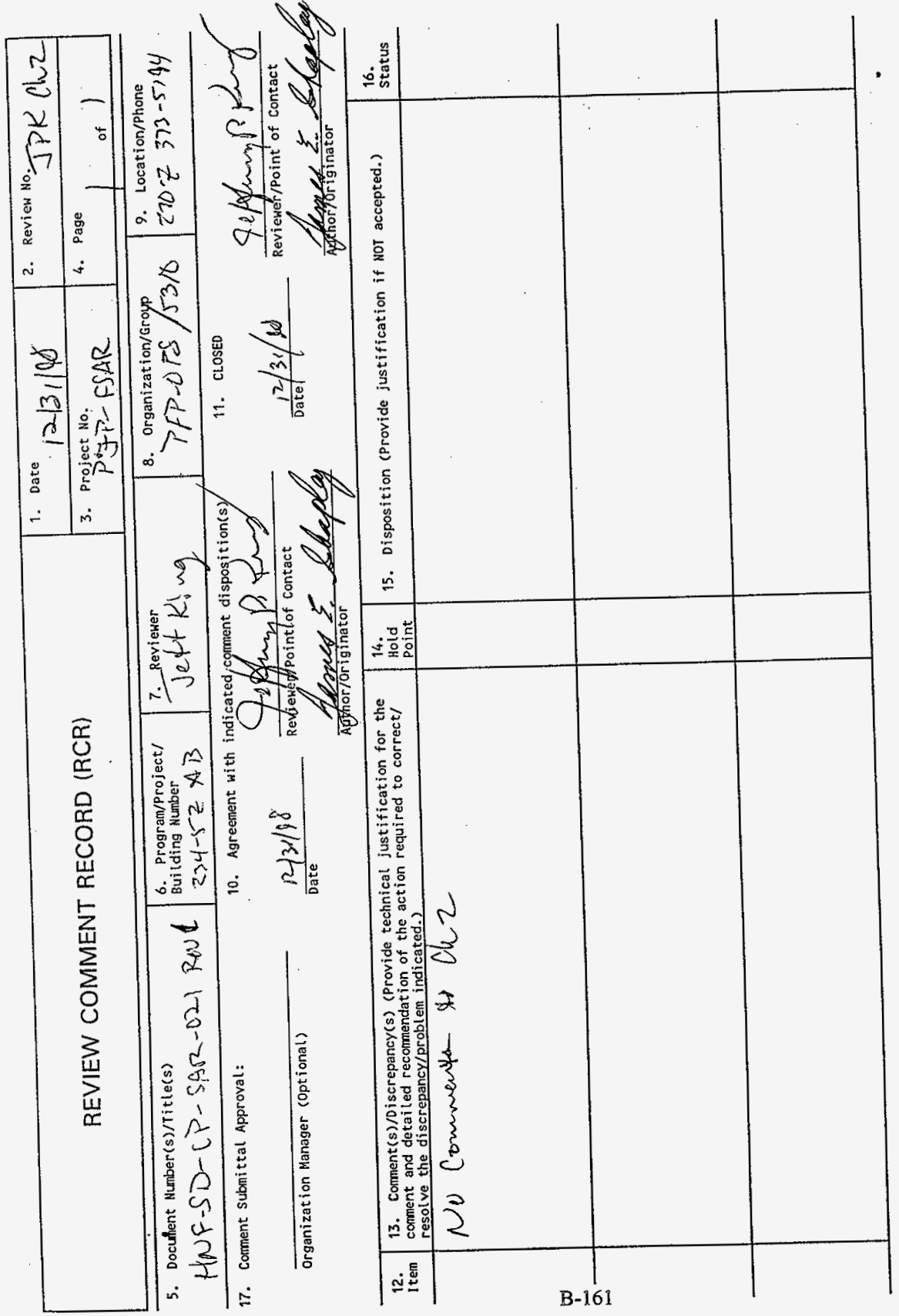

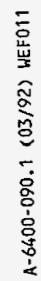




\section{REVIEW COMMENT RECORD (RCR)}

\begin{tabular}{|l|l|}
\hline 1. Date & 2. Review No. \\
\hline 3. Project No. & 4. Page 1 of 1 \\
\hline
\end{tabular}

5. Document Number(s)/Title(s)
HNF-SD-CP-SAR-021, Chapter 9

17. Comment Subnittal Approval:

Organization Manager (optional)

6. Program/Project/
8uilding Number
PFP SAR

7. Reviewer

H. R. Risenmay

10. Agreement with indicated comment disposition(s)

Date

Reviewer/Point of contact

Author/Originator

\section{Organization/Group \\ PFP Process \\ Engineering}

11. CLOSED

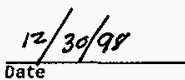

9. Location/Phone

$2702 / 20 / 200 \mathrm{~W}$

373-3503

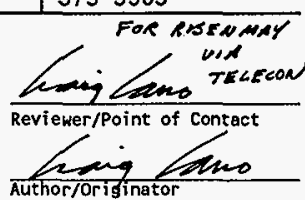

Author/Orisinator

\begin{tabular}{|c|c|c|c|c|}
\hline $\begin{array}{l}12 . \\
\text { Iten }\end{array}$ & $\begin{array}{l}\text { 13. Comment(s)/Discrepancy(s) (Provide technical justification for the } \\
\text { comment and detai led recommendation of the action required to correct/ } \\
\text { resolve the discrepancy/problem indicated.) }\end{array}$ & $\begin{array}{l}14 . \\
\text { Hoid } \\
\text { Point }\end{array}$ & 15. Disposition (Provide justification if NOT accepted.) & $\begin{array}{l}16 . \\
\text { Status }\end{array}$ \\
\hline 1. & Minor editorial comments. & & Corrected per comments. & \\
\hline & & & & \\
\hline & & & & \\
\hline & & & & \\
\hline & & & & \\
\hline & & & & \\
\hline & & & & \\
\hline & & & & \\
\hline & & & & \\
\hline & & & & \\
\hline & & & & \\
\hline & & & & \\
\hline & & & & \\
\hline & & & & 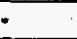 \\
\hline & & & & \\
\hline & 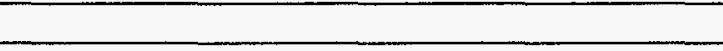 & & - & \\
\hline
\end{tabular}




\section{REVIEW COMMENT RECORD (RCR)}

\begin{tabular}{|c|l|}
\hline $\begin{array}{l}\text { 1. Date } \\
12 / 22 / 98\end{array}$ & 2. Review Ho. \\
\hline $\begin{array}{c}\text { 3. Project No. } \\
\text { PFP SAR }\end{array}$ & 4. Page 1 of 2 \\
\hline
\end{tabular}

5. Document Number(s)/Title(s)

HNF-SD-CP-SAR-021, Chapter 9
6. Program/Project/ Building Number PFP SAR

10. Agreement with indicated coment disposition(s)

17. Comment Submittal Approval:

Organization Manager (Optional)

Date
7. Reviewer

D. R. Groth

8. organization/Group
PFP Quality
Assurance

Reviewer/Point of Contact
11. CLOSED

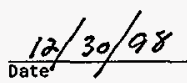

Author/originator

9. Location/Phone

Mo $017 / / 200 \mathrm{~W}$

373-5029

FOR DON GROTH

TELFCON

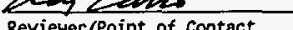

Reviewer/Point of contac

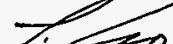

Authorforiginator

\begin{tabular}{|c|c|c|c|c|}
\hline \multirow[b]{2}{*}{$\begin{array}{l}\text { 12. } \\
\text { Item }\end{array}$} & \multicolumn{2}{|c|}{ Author/originator } & \multicolumn{2}{|c|}{ Authofforiginator } \\
\hline & $\begin{array}{l}\text { 13. Comment( } s \text { )/Discrepancy(s) (Provide technical justification for the } \\
\text { comment and detailed recomendation of the action required to correct/ } \\
\text { resolve the discrepancy/problem indicated.) }\end{array}$ & $\begin{array}{l}14 . \\
\text { Hold } \\
\text { Point }\end{array}$ & 15. Disposition (Provide justification if NOT accepted.) & $\begin{array}{l}16 . \\
\text { status }\end{array}$ \\
\hline 1. & $\begin{array}{l}\text { Page 9-6, 4th para: Some of the information in } \\
\text { parentheses in the sentence beginning "Operations } \\
\text { supporting..." is outdated or misleading. Canning } \\
\text { is no longer done in HC-21A, and although a TGA has } \\
\text { not yet been installed in } 18 \mathrm{M} \text {, LOIs are now done } \\
\text { elsewhere. I'll suggest htat this information be } \\
\text { simplified and replaced with "( } 1 . e ., \text { delivery of Pu } \\
\text { nitrate solutions and the LOI testing and canning of } \\
\text { the calcinated product)". }\end{array}$ & & Corrected per comment. & \\
\hline 2. & $\begin{array}{l}\text { Page 9-171, 9.2.4.2.1Y: Typo..." contguous" should be } \\
\text { "contiguous." }\end{array}$ & & Corrected per comment. & \\
\hline
\end{tabular}




\begin{tabular}{|c|c|c|}
\hline \multirow{2}{*}{ REVIEW COMMENT RECORD (RCR) } & $\begin{array}{l}\text { 1. Date } \\
12 / 22 / 98\end{array}$ & 2. Review No. \\
\hline & $\begin{array}{l}\text { 3. Project No. } \\
\text { PFP SAR }\end{array}$ & 4. Page \\
\hline
\end{tabular}

\begin{tabular}{|c|c|c|c|c|}
\hline $\begin{array}{l}12 . \\
\text { It tem }\end{array}$ & $\begin{array}{l}\text { 13. Comment(s)/Discrepancy(s) (Provide technical justification for the } \\
\text { comment and detai led recommendation of the action required to correct/ } \\
\text { resolve the discrepancy/problem indicated.) }\end{array}$ & $\begin{array}{l}14 . \\
\text { Hoid } \\
\text { point }\end{array}$ & 15. Disposition (Provide justification if NOT accepted.) & $\begin{array}{l}\text { 16. } \\
\text { Status }\end{array}$ \\
\hline 3. & $\begin{array}{l}\text { Page 9-274, Bin E, first sentence regarding } \\
\text { HC-230-2: I looked to OSR-010's Table } 5.22 \text { and } \\
\text { noticed no entry for HC-230-2 or its } 27 \mathrm{~kg} \text { of } \mathrm{Pu} \\
\text { material. I discussed with Jeff King who added that } \\
\text { OSR-010's Table } 5.22 \text { has been replicated in } \\
\text { Chapter } 9 \text { as Table } 9.25 \text {. I have two } \\
\text { recommendations... } \\
\text { r- Revise this first sentence to read "Criticality } \\
\text { risks for Glovebox HC-230-2 has been analyzed } \\
\text { assuming storage of a maximum of approximately } 27 \mathrm{~kg} \\
\text { of Pu material.". } \\
\text {-- I agree with Jeff that Table } 5.22 \text { not be } \\
\text { replicated in the FSAR. Aside from the fact that } \\
\text { the HC-230-2 entry is aTluded to but does not exist } \\
\text { and the possibility of transcription errors, OSR-010 } \\
\text { and the FSAR would have to be revised simultaneously } \\
\text { to be consistent. }\end{array}$ & & $\begin{array}{l}\text { Corrected per comment. } \\
\text { Comment is understood but must retain Tables } \\
9-25 \text { and } 9-26 \text { as they are the basis for the } \\
\text { source term assumptions. }\end{array}$ & \\
\hline 4. & $\begin{array}{l}\text { Page R9-16: } \\
\text {-- Format. HNF-PRO-062. Fluor Daniel... should not } \\
\text { be in italics. } \\
\text {-- Safety Analysis Manual: The document ID, "FSP- } \\
\text { PFP" is missing a numbered suffix. Al so, "Babcock } \\
\text { and Wilcox..." should be "B\&W Hanford Company". }\end{array}$ & & $\begin{array}{l}\text { Corrected per comment. } \\
\text { Corrected per comment. }\end{array}$ & \\
\hline & & & & \\
\hline & & & & \\
\hline & & & & \\
\hline & & & & \\
\hline & & & & \\
\hline & & & & \\
\hline & & & & \\
\hline
\end{tabular}




\section{REVIEW COMMENT RECORD (RCR)}

\begin{tabular}{|l|l|}
\hline $\begin{array}{l}\text { 1. Date } 12 / 29 / 98 \\
\text { 3. Project No. }\end{array}$ & 2. Review No. \\
\hline & 4. Page 1 of 1 \\
\hline
\end{tabular}

\section{Document Number(s)/Title(s) \\ HNF-SD-CP-SAR-021, Chapter $2 \& 9$}

6. Progran/Project/ Building Number

PFP SAR

7. Reviewer
C. D. Woll am

10. Agreement with indicated comment disposition(s)

Organization Manager (Optional)

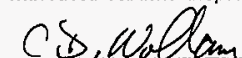

Reviewer/Point of Contact

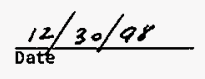

Author/Griginator

8. Organization/Group

Technical Integration

11. CLOSED

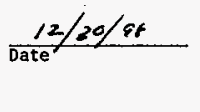

9. Location/Phone

2753E/B104/200E $373-1587$

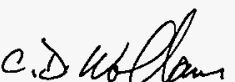

Reviewer/Point of Contact

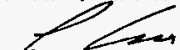

Author/Origingtor

\begin{tabular}{|c|c|c|c|c|}
\hline $\begin{array}{ll}2 . \\
\text { Item }\end{array}$ & 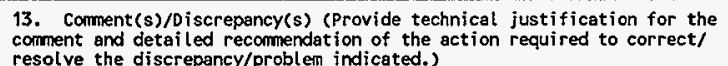 & 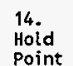 & 15. Disposition (Provide justification if NOT accepted.) & 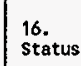 \\
\hline 1. & Comments submitted as chapter mark-up. & & Comments incorporated as appropriate. & \\
\hline & & & & \\
\hline & & & & \\
\hline & & & & \\
\hline & & & & \\
\hline & & & & \\
\hline & & & & \\
\hline & & & & \\
\hline & & & & \\
\hline & & & & \\
\hline & & & & \\
\hline & & & & \\
\hline & & & & \\
\hline & & & & \\
\hline
\end{tabular}




\section{REVIEW COMMENT RECORD (RCR)}

\begin{tabular}{|l|l|}
\hline 1. Date & 2. Review No. \\
\hline 3. Project No. & 4. Page \\
\hline
\end{tabular}

\begin{tabular}{l|l|l|l}
\hline 5. Document Number(s)/Title(s) & $\begin{array}{l}\text { 6. Program/Project/ } \\
\text { Building Number } \\
\text { PFP }\end{array}$ & 7. Reviewer & 8. Organization/Group \\
HNF-SD-CP-SAR-021, Rev.1 & HM BUCCI & $\begin{array}{l}\text { FDH - Location/Phone } \\
\text { SAFETY \& FIRE } \\
\text { PROTECTION }\end{array}$ \\
\hline
\end{tabular}

17. Comment Submittal Approval:

Organization Manager (Optional)

$\stackrel{\square}{\stackrel{1}{a}}$

g
10. Agreement with indicated comment disposition(s)

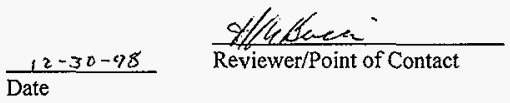

Author/Originator
11. CLOSED

$12-30-48$

Date

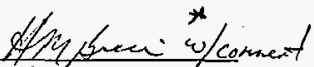
Reviewer/Point of Contact

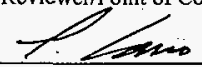

Author/Originator

\section{(15. Disposition (Provide justification if NOT accepted)}

Ite 13. Comment(s)/Discrepancy(s) (Provide technical justification for the

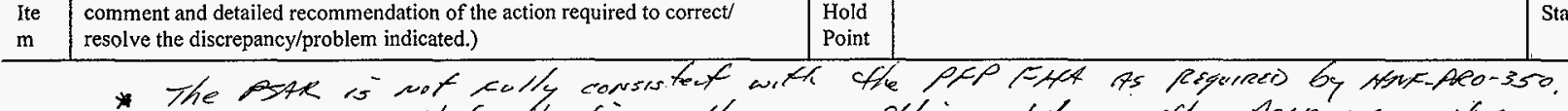

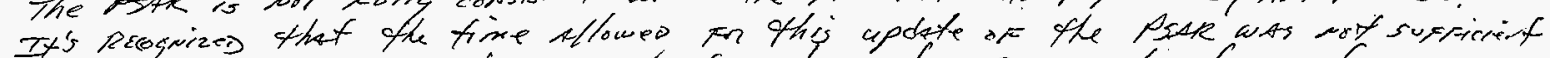

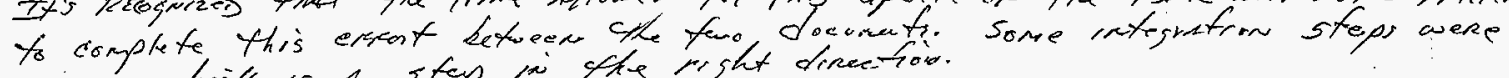
miate whreit is at stop in ctite right divention. 


\begin{tabular}{|l|l|}
\hline 1. Date & 2. Review No. \\
\hline 3. Project No. & 4. Page \\
\hline
\end{tabular}

1. $\quad$ Due to time restraints this review was limited to sections of chapter 9 only.

The FSAR should simply reference the FHA scenarios for it's fire analyses and calculate dose consequences based on those scenario's where a breach of confinement is expected. (It's not appropriate to have two separate documents addressing the same analyses with different conclusions, e.g. The events should be agreed upon so one document is not discrediting the other by concluding events are "incredible").
The FHA and FSAR are logically consistent, but not identical. Concur with commentor's statement that there should not be two separate documents addressing the same analyses with different conclusions. However, they are not the SAME analyses. The MPFL analyses presented in the FHA are unmitigated (with the exception of the fire barriers). The PFP FSAR does not present unmitigated analyses. The MCFL in the FHA takes credit for activation of the sprinkler system. In the case of the RMC Line fire, the sprinkler system is assumed to fail and credit is taken for response of the HFD. Although design features are preferable to administrative controls, it is the facility's prerogative to select controls based on consideration of effectiveness and ease of implementation. Note that disregarding the sprinkler system altogether (i.e., dropping its failure frequency out of the probability calculation) does not alter the risk acceptability argument. As stated in the FSAR, the RMC Line fire consequences are acceptable for all probability categories.

Based on the reviewer's comment, the FHA was re-read. It is believed that the two documents do not discredit each other, but are mutually supportive. In regards to the reviewer's example of the FSAR finding the RMC Line "incredible," this does not discredit the FHA analysis as the FHA does not quantify MPFL and MCFL scenario probabilities. FSAR text will revised to state that a fire in the RMC Line is credible (this can currently be inferred from Item C-1 in Section 9.2.2.A.2, Probability, which has an annual probability of $2.5 \mathrm{E}-2$ ), but that a fire that grows and spreads to all of the gloveboxes in Rooms $228 \mathrm{~A}, \mathrm{~B}$, and C is not credible based on the combination of required failures.

To avoid the perception of conflicting scenarios, the FSAR text has also been revised to state that the unmitigated MPFL spreads to all of RMC and RMA lines, but that crediting the HFD the FSAR limits the spread to Rooms $228 \mathrm{~A}, \mathrm{~B}$, and C. Further, the FSAR text has been revised to state that the FHA concludes that the RMC/RMA line does not result in a direct release out of the facility. 


\begin{tabular}{|l|l|l|}
\hline REVIEW COMMENT RECORD (RCR) & 1. Date & \\
\cline { 2 - 3 } & 3. Project No. & 4. Page \\
\hline
\end{tabular}

\begin{tabular}{|c|c|c|}
\hline 2. & $\begin{array}{l}\text { Pg.9-131, Sect.9.2.2: The second paragraph indicates that the FHA fire } \\
\text { scenario of the analytical laboratory was not analyzed in the FSAR because the } \\
\text { consequences were qualitatively evaluated and bounded by the worst case } \\
\text { glovebox area fire. It would be more appropriate to base the reason for not } \\
\text { analyzing the scenario further because the FHA demonstrated that a breach of } \\
\text { confinement from this event would not occur (although the E-3 filters may } \\
\text { plug resulting in reduced negative pressure and contamination spread within } \\
\text { the building). Add this additional text (reasoning) to this section. }\end{array}$ & $\begin{array}{l}\text { Additional text added per comment. } \\
\text {. }\end{array}$ \\
\hline 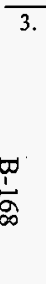 & $\begin{array}{l}\text { Pg.9-134, Sect.9.2.2A.1: This scenario should reference the FHA glovebox } \\
\text { scenario rather then producing a separate methodology. The FHA did not } \\
\text { postulate breach of confinement as a result of the glovebox scenario, however } \\
\text { the FSAR includes a probability review for the scenario and it's unclear as to } \\
\text { why this is necessary since a radiological release was not postulated (?). If } \\
\text { credit is being taken for the fire suppression systems to mitigate an otherwise } \\
\text { unacceptable event, then these systems would need to be safety class or safety } \\
\text { significant. If an unacceptable release has not been postulated, then it would } \\
\text { seem the probability review is unnecessary. }\end{array}$ & $\begin{array}{l}\text { This section does reference the FHA as the comment says it should } \\
\text { but credits response by the HFD to control the fire versus } \\
\text { activation of the sprinkler system. Given a delayed response by } \\
\text { the HFD, it is assumed that a breach of confinement (i.e., the } \\
\text { gloveboxes) does occur. Refer to response \#1 regarding taking } \\
\text { credit for HFD versus the sprinkler system and corresponding } \\
\text { impact to the probability and risk acceptance arguments. } \\
\text { Text has been revised to state FHA conclusion that an RMC line } \\
\text { fire does not result in a direct release from the facility. }\end{array}$ \\
\hline 4. & $\begin{array}{l}\text { A. Pg.9-141, Sect.9.2.2B.1: The FFA postulated a breach of confinement as } \\
\text { a result of the hydraulic oil fire and the FSAR takes credit for the sprinkler } \\
\text { system (section 9.2.2B.2) and the dike provided to contain the spill. } \\
\text { However, the FSAR only identifies the dike as a safety class SSC. It } \\
\text { would seem that the sprinkler system must also be a safety class SSC. } \\
\text { B. Sect.9.2.2B.5: change the last sentence to read, ".....thus limiting the } \\
\text { number of structural steel members exposed to the fire". }\end{array}$ & $\begin{array}{l}\text { A. The analysis states that the diked area and sprinklers both } \\
\text { provide mitigation. Section } 9.2 .2 \mathrm{~B} .3 \text { and } .4 \text { specifically stated that } \\
\text { it is the diked area that is credited with preventing collapse of the } \\
\text { roof. Text has been revised to state that: "Although not } \\
\text { specifically credited with preventing collapse of the roof, the wet } \\
\text { pipe sprinkler system also provides mitigation in the event of a } \\
\text { hydraulic oil fire. } \\
\text { B. Last sentence revised per comment }\end{array}$ \\
\hline
\end{tabular}




\section{REVIEW COMMENT RECORD (RCR)}

\begin{tabular}{|l|l|}
\hline 1. Date & 2. Review No. \\
\hline 3. Project No. & 4. Page \\
\hline
\end{tabular}

\begin{tabular}{|c|c|c|}
\hline 5. & $\begin{array}{l}\text { Pg.T9-1, Table 9-1: Identifying the scenarios in sections } 9.2 .2 \mathrm{~A} \text { and } 9.2 .2 \mathrm{~B} \text { as } \\
\text { "incredible" is inappropriate in view of the FHA of these scenarios. If a dose } \\
\text { consequence was not calculated for the hydraulic oil fire, it's unclear how the } \\
\text { dike being used to confine the spill was determined to be a safety class SSC? } \\
\text { This apparent discrepancy needs to be addressed. }\end{array}$ & $\begin{array}{l}\text { The FHA does not address the probability of MPFL or MCFL } \\
\text { scenarios. As stated above, an RMC Line fire is not incredible, but } \\
\text { one that involves all of the gloveboxes in Rooms } 228 \mathrm{~A}, \mathrm{~B} \text {, and C } \\
\text { is based on the required failures. Similarly, a hydraulic oil fire in } \\
\text { Room } 321 \text { is not incredible, but, taking credit for the diked area, a } \\
\text { fire that results in collapse of the roof is. As stated in the FSAR, } \\
\text { the diked berm was designated safety class as it protects the } \\
\text { facility structure that is safety class. Text has been revised to } \\
\text { address the spray leak issue. }\end{array}$ \\
\hline 6. & $\begin{array}{l}\text { A. Pg.9-231: This section should reference the FHA for the dynamics of the } \\
\text { RMC line fire to preclude multiple (and at times conflicting) scenarios. } \\
\text { B. The second bullet refers to lexan as being fire resistant. A more } \\
\text { appropriate (accurate) term would be fire retardant. }\end{array}$ & $\begin{array}{l}\text { A. Based on the reviewer's comment, the FHA was re-read. } \\
\text { Although there are differences between the MPFL and MCFL } \\
\text { analyses in the FHA and the analysis in the FSAR, the analyses are } \\
\text { not in conflict as they are not identical analyses performed for the } \\
\text { same purpose. } \\
\text { B. Text revised per comment. }\end{array}$ \\
\hline 7 & $\begin{array}{l}\text { Pg.9-237, Sect.9.2.4.6.3.1.E: Safety controls must be in place to prevent the } \\
\text { potential for asphyxiation due to an argon release (reference recent INEEL } \\
\text { fatality). It wasn't clear where this was discussed in the FSAR. }\end{array}$ & $\begin{array}{l}\text { A re-evaluation of the asphyxiation hazard of argon was not part of } \\
\text { the scope of this revision as defined by the criteria document. The } \\
\text { next FSAR revision must specifically address this hazard and the } \\
\text { associated controls. }\end{array}$ \\
\hline & & \\
\hline & & \\
\hline & & \\
\hline
\end{tabular}




\begin{tabular}{|l|l|l|}
\hline \multirow{2}{*}{ REVIEW COMMENT RECORD (RCR) } & i. Date Review No. & \multicolumn{1}{|c|}{$12 / 21 / 98$} \\
\cline { 2 - 3 } & 3. Project No. & 4. Page \\
\end{tabular}

\begin{tabular}{|c|l|l|l|l|l|l|}
\hline 5. Document Number(s)/Title(s) & $\begin{array}{l}\text { 6. Program/Project/ } \\
\text { Building Number } \\
\text { PFP SAR }\end{array}$ & $\begin{array}{l}\text { 7. Reviewer } \\
\text { A. M. Horner }\end{array}$ & 8. Organization/Group \\
\hline
\end{tabular}

17. Comment Submittal Aporoval:

Organization Manager (Optional)

10. Agreement with indicated comment disposition(s)
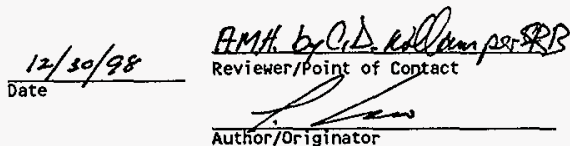

11. CLOSED

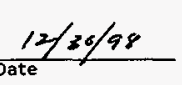

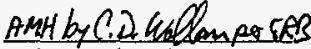

Reviewer/Point of Contact

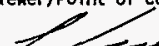

Aut

\begin{tabular}{|c|c|c|c|c|}
\hline $\begin{array}{l}12 . \\
\text { Item }\end{array}$ & $\begin{array}{l}\text { 13. Comment(s)/Discrepancy(s) (Provide technical justification for the } \\
\text { comment and detailed recomnendation of the action required to correct/ } \\
\text { resolve the discrepancy/problem indicated.) }\end{array}$ & $\begin{array}{l}14 . \\
\text { Hold } \\
\text { Point }\end{array}$ & 15. Disposition (Provide justification if NOT accepted.) & $\begin{array}{l}16 . \\
\text { Status }\end{array}$ \\
\hline 1 & $\begin{array}{l}\text { The probabilistic analysis in } 9.2 .2 A .2 \text { has not } \\
\text { incorporated SRB comments at this point and is not } \\
\text { of acceptable qual ity with out revision. }\end{array}$ & & $\begin{array}{l}\text { The probability analysis has been revised } \\
\text { per SRB and other reviewer comments. The } \\
\text { new annual probability is (rounding up) } \\
3.2 \mathrm{E}-7 \text { based on: } \\
\qquad \begin{array}{l}(2.5 \mathrm{E}-2)(2.1 \mathrm{E}-1)(3 \mathrm{E}-1) \\
(1 \mathrm{E}-1)(2 \mathrm{E}-3)=3.15 \mathrm{E}-7\end{array}\end{array}$ & . \\
\hline 2 & $\begin{array}{l}9.2 .4 .2 .1 \mathrm{~V}, \text { 2nd paragraph concludes that no release } \\
\text { is postulated because it is unlikely that material } \\
\text { is in the system during the seismic event. An } \\
\text { acceptable criteria for dismissing the release would } \\
\text { be the release being incredible or insignificant } \\
\text { compared with other releases during the seismic } \\
\text { event. }\end{array}$ & & $\begin{array}{l}\text { The seismic analysis assumes that gloveboxes } \\
\text { are loaded to their CPS limits and that the } \\
\text { conveyor gloveboxes are empty. The conveyor } \\
\text { gloveboxes are normally empty as they are } \\
\text { only used for interglovebox material } \\
\text { transfers. You cannot logically assume that } \\
\text { the gloveboxes are at their CPS limits and } \\
\text { that there is material in a conveyor because } \\
\text { the material would have to have came from } \\
\text { some glovebox (such that that glovebox would } \\
\text { no longer be at its CPS limit) and it would } \\
\text { have to be going to some glovebox (which } \\
\text { would have to be below its cPS } 1 \text { imit to } \\
\text { accept the transfer). This argument has } \\
\text { been added to Section } 9.2 .4 .2 \text {. }\end{array}$ & \\
\hline
\end{tabular}




\begin{tabular}{|l|l|l|}
\hline \multirow{2}{*}{ REVIEW COMMENT RECORD (RCR) } & 1. Date $12 / 23 / 98$ & Review No. \\
\cline { 2 - 4 } & 3. Project No. & 4. Page \\
\hline
\end{tabular}

\begin{tabular}{|c|c|c|c|c|}
\hline $\begin{aligned} \text { 5. Document Number(s)/Title(s) } \\
\text { HNF-SD-CP-SAR-021 }\end{aligned}$ & $\begin{array}{l}\text { 6. Program/Project/ } \\
\text { Buil lding Number } \\
\text { PFP SAR }\end{array}$ & $\begin{array}{l}\text { 7. Reviewer } \\
\text { P. R. Prevo }\end{array}$ & 8. Organization/Group & 9. Location/Phone \\
\hline
\end{tabular}

17. Comment Submittal Approval:

Organization Manager (Optional)
10. Agreement with indicated coment disposition(s)

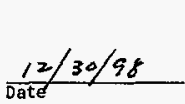

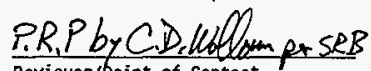

Reviewer/Point of Contect

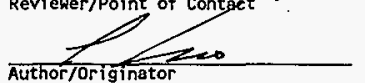

11. CLOSED

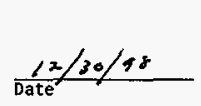

ERPR RCDUblomparSRB Reviewer/Point of Contact

\begin{tabular}{|c|c|c|c|c|}
\hline & & & & \\
\hline $\begin{array}{l}12 . \\
1 \text { tem }\end{array}$ & $\begin{array}{l}\text { 13. Comment(s)/Discrepancy(s) (Provide technical justification for the } \\
\text { comment and detailed recomenciation of the action required to correct/ } \\
\text { resolve the discrepancy/problem indicated.) }\end{array}$ & $\begin{array}{l}14 . \\
\text { Hold } \\
\text { Point }\end{array}$ & 15. Disposition (Provide justification if Nor accepted.) & $\begin{array}{l}16 . \\
\text { Status }\end{array}$ \\
\hline 1. & 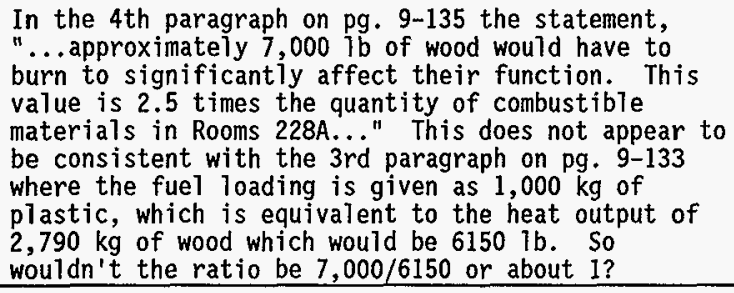 & & $\begin{array}{l}\text { Corrected per comment. The conclusion is } \\
\text { still reached that the filters would not be } \\
\text { significantly affected. You are still } \\
\text { approx. } 900 \text { pounds short }(7040 / 6250) \text { and } \\
\text { that is if all of the smoke goes the E-4 } \\
\text { route. It is believed that in fact the } \\
\text { majority of the smoke would be released into } \\
\text { the room as the large plastic panels burned. }\end{array}$ & \\
\hline 2. & $\begin{array}{l}\text { Section } 9.2 .2 A .2 \text {. Some of the probabilities given } \\
\text { in the bullets are not consistent with those used in } \\
\text { the following text, } \mathrm{e.9}, \mathrm{g}^{-3} \text { inition of significant } \\
\text { fuel is given as } 2.5 \times 10^{-3} \text { in the first bullet and } \\
\text { as } 2.5 \mathrm{c} \text { in the text. }\end{array}$ & & Corrected per comment. & \\
\hline 3. & $\begin{array}{l}\text { Section } 9.2 .2 A .2, \text { D-1 Fire Not Noticed. The } \\
\text { discussion does not seem to support the stated } \\
\text { probability of } 1 E-2 \text { per demand. }\end{array}$ & & $\begin{array}{l}\text { Text simplified to state that the estimate } \\
\text { is based on the fact that fires have } \\
\text { occurred despite a fire watch. Note that } 2 \text { - } \\
2 \text { has } 1 \text { ittle influence on the overall event } \\
\text { probability as } 0-2 \text { is an order of magnitude } \\
\text { larger. }\end{array}$ & . \\
\hline
\end{tabular}




\begin{tabular}{|l|l|l|}
\hline \multirow{2}{*}{ REVIEW COMMENT RECORD (RCR) } & 1. Date & \multicolumn{2}{|c|}{ Review No. } \\
\cline { 2 - 3 } & 3. Project No. & 4. Page \\
\hline
\end{tabular}

\begin{tabular}{|c|c|c|c|c|}
\hline Item & $\begin{array}{l}\text { 13. Comment(s)/Discrepancy(s) (Provide technical justification for the } \\
\text { comment and detailed recommendation of the action required to correct/ } \\
\text { resolve the discrepancy/problem indicated.) }\end{array}$ & $\begin{array}{l}14 . \\
\text { Hold } \\
\text { Point } \\
\end{array}$ & 15. Disposition (Provide justification if NOT accepted.) & $\begin{array}{l}16 . \\
\text { Status }\end{array}$ \\
\hline 4. & $\begin{array}{l}\text { Section 9.2.2.A.2, C-3, end of paragraph, last } \\
\text { sentence. Believe the sentence should read, "with } \\
\text { all these considerations, a probability of failure } \\
\text { to extinguish..." }\end{array}$ & & Corrected per comment. & \\
\hline 5. & $\begin{array}{l}\text { Section 9.2.2.A.3. Should state why consequences are } \\
\text { calculated since the accident is not credible. }\end{array}$ & & $\begin{array}{l}\text { Revised frequency is approximately credible } \\
\text { (i.e., } 3.2 \mathrm{E}-7 \text { ). }\end{array}$ & \\
\hline 6. & $\begin{array}{l}\text { Section } 9.2 .2 A .2 \text {. I get } 7.5 \mathrm{E}-10 \text { for the probability } \\
\text { instead of the stated } 1.6 \mathrm{E}-9 \text {. }\end{array}$ & & $\begin{array}{l}\text { New probability is } 3.2 \mathrm{E}-7 \text { based on: } \\
(2.5 \mathrm{E}-2)(2.1 \mathrm{E}-1)(3 \mathrm{E}-1)(1 \mathrm{E}-1)(2 \mathrm{E}-3)=3.15 \mathrm{E}-7\end{array}$ & \\
\hline
\end{tabular}

$\dot{1}$
부 


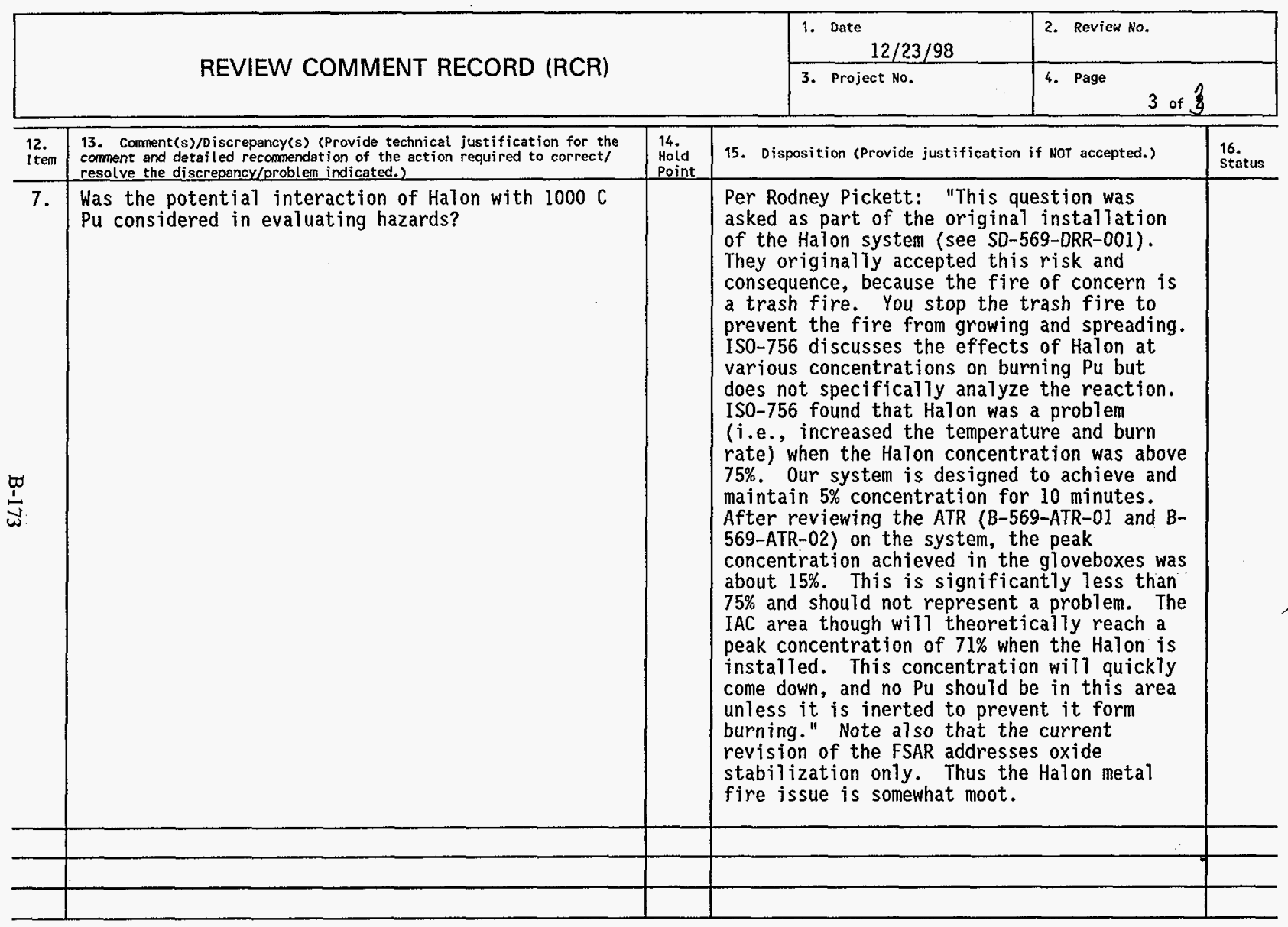




\section{Rief, Gloria J}

From:

Sent:

To:

Cc:

Subject:
Prevo, Paul R

Wednesday, December 30, 1998 4:56 PM

Rief, Gloria J; Horner, Alan M; Wollam, C D (Chris)

Prevo, Paul R

RE: RCRs attached in WP5.1

\section{Chris,}

Responses to my comments are acceptable to me.

\section{Paul}

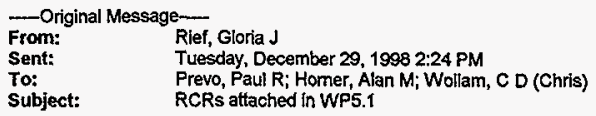

Gloria for Craig Carro

《 File: PFP-RCR.AMH $\gg>$ File: PFP-RCR.PRP $\gg$ 


\section{REVIEW COMMENT RECORD (RCR)}

\begin{tabular}{|l|l|}
\hline 1. Date & 2. Review No. \\
\hline 3. Project No. & 4. Page \\
\hline
\end{tabular}

\begin{tabular}{l|l|l|l|l|l|}
\hline 5. Document Number(s)/Title(s) & $\begin{array}{l}\text { 6. Program/Project/ } \\
\text { Building Number } \\
\text { PFP SAR }\end{array}$ & $\begin{array}{l}\text { 7. Reviewer } \\
\text { R. D. Pickett }\end{array}$ & $\begin{array}{l}\text { 8. Organization/Group } \\
\text { PFP Facility Systems } \\
\text { Engineer }\end{array}$ & \begin{tabular}{l} 
M0 016/372-1072 \\
\hline
\end{tabular}
\end{tabular}

17. Comment Submittal Approval:

$\overline{\text { Organization Manager (optional) }}$
10. Agreement with indicated comment disposition(s).

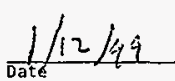

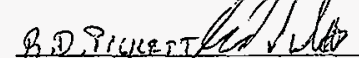

Reviewer/Point of Contact

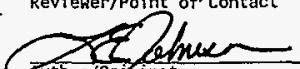

Author/orfinator

11. CLOSED
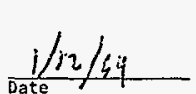

Reviewer/Point of Contact

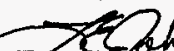

Atror/orjginator

\begin{tabular}{|c|c|c|c|c|}
\hline $\begin{array}{l}12 . \\
\text { Item }\end{array}$ & $\begin{array}{l}\text { 13. Comment(s)/Discrepancy(s) (Provide technical justification for the } \\
\text { comment and detailed recormendation of the action required to correct/ } \\
\text { resolve the discrepancy/problem indicated.) }\end{array}$ & $\begin{array}{l}14 . \\
\text { Hold } \\
\text { Point }\end{array}$ & 15. Disposition (Provide justification if NOT accepted.) & $\begin{array}{l}16 . \\
\text { Status }\end{array}$ \\
\hline 1. & $\begin{array}{l}\text { Section } 5.4 .11 .3 .8 \text { - The MPFL } \$ \text { amount should be } \\
\$ 2,227,000 \text { instead of } \$ 2,270,000 \text {. }\end{array}$ & & Accept. Text revised as recommended. & \\
\hline 2. & $\begin{array}{l}\text { Section } 5.4,11.2 .3 \text { - The backup power to the fire } \\
\text { protection system is batteries normally. Some fire } \\
\text { control panels do also get power from panels } \\
\text { supported by the diesels, but not as a hard and } \\
\text { rule. }\end{array}$ & & Accept. Text revised appropriately. & . \\
\hline 3. & $\begin{array}{l}\text { Sections } 5.4 .11 .2 .6 \text { and } 9.2 .2 \mathrm{~A} .1 \text { - The Halon } \\
\text { concentration according to the Halon ATP is } 5 \% \\
\text { instead of } 6 \% \text {. }\end{array}$ & & Accept. Text revised as recommended. & \\
\hline 4. & $\begin{array}{l}\text { Section } 9.2 .2 A .2 \text { - The probability for } C-1 \text { does not } \\
\text { agree between the paragraph } C-1 \text { and the first } \\
\text { paragraph in the section. }\end{array}$ & & The correct value for $c-1$ is $2.5 \mathrm{E}-2$. & \\
\hline
\end{tabular}




\section{REVIEW COMMENT RECORD (RCR)}

\begin{tabular}{|l|l|}
\hline \multicolumn{1}{|l|}{$12 / 21 / 98$} & 2. Revien No. \\
\hline 3. Project No. & 4. Page \\
& 1 of 3 \\
\hline
\end{tabular}

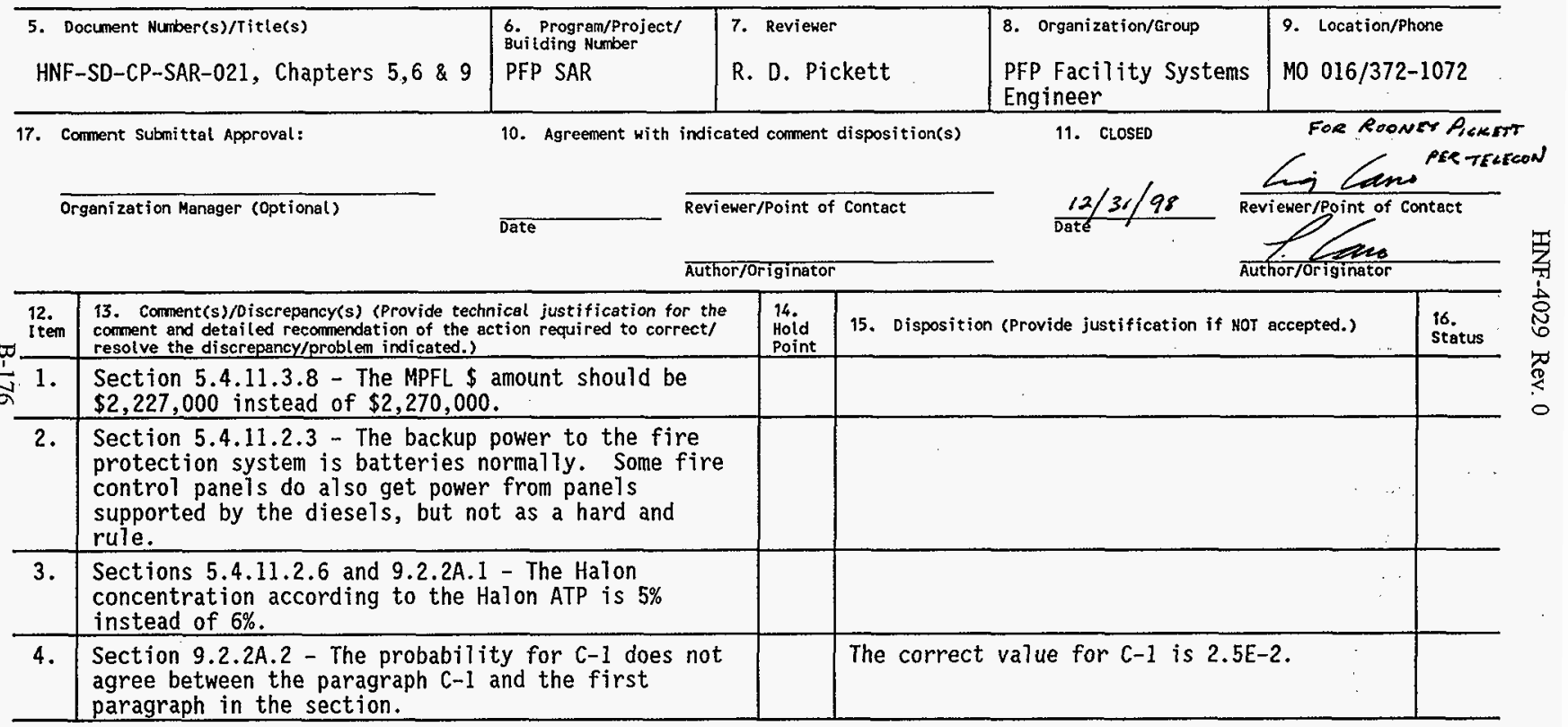




\begin{tabular}{|l|l|l|}
\hline \multirow{2}{*}{ REVIEW COMMENT RECORD (RCR) } & 1. Date $12 / 21 / 98$ & 2. Reviex No. \\
\cline { 2 - 4 } & 3. Project No. & 4. Page \\
\hline
\end{tabular}

\begin{tabular}{|c|c|c|c|c|}
\hline $\begin{array}{ll}12 . \\
\text { I tem } \\
\end{array}$ & $\begin{array}{l}\text { 13. Comment(s)/piscrepancy(s) (Provide technical justification for the } \\
\text { comment and detai ied recormendation of the action required to correct/ } \\
\text { resolve the discrepancy/problem indicated.) }\end{array}$ & $\begin{array}{l}14 . \\
\text { Hoid } \\
\text { Point }\end{array}$ & 15. Disposition (Provide justification if Nor accepted.) & $\begin{array}{l}16 . \\
\text { Status }\end{array}$ \\
\hline 5. & $\begin{array}{l}\text { Section } 9.2 .2 A .2 \text { - The probability for } D-1 \text { is } \\
\text { missing from the first paragraph. }\end{array}$ & & $\begin{array}{l}\text { Text revised to state "People fail to take } \\
\text { proper action following ignition - 2.1E- } \\
1 \text { /demand (fire not noticed or corrected).". } \\
\text { Note that D-1 and D-2 are under an "or" gate } \\
\text { and thus the values are added }(.2+.01= \\
2.1 \mathrm{E}-1)\end{array}$ & \\
\hline 6. & $\begin{array}{l}\text { Section 9.2.2A.2, paragraph C-6 - The fire alarms } \\
\text { are not connected to the MICON. They currently } \\
\text { alarm at the Flex } 500 A \text { panel and are transmitted to } \\
\text { the fire department. Only the } 2736-Z B \text { fire alarm is } \\
\text { connected to the MICON. }\end{array}$ & & $\begin{array}{l}\text { Text revised to state "Building 234-5Z fire } \\
\text { alarms alarm at the Flex 500A panel...." }\end{array}$ & \\
\hline 7. & $\begin{array}{l}\text { Section } 9.2 .2 \mathrm{~B} .2 \text { - Where did the volume of } 340 \\
\text { gallons for the dike come from? The only number I } \\
\text { have seen was } 170 \text { gallons. }\end{array}$ & & $\begin{array}{l}\text { The berm is reported to be } 13 \mathrm{ft} \text { by } 7 \mathrm{ft} \text { by. } \\
6 \text { inches. The associated volume is } 340 \text {. I } \\
\text { am not positive, but most berms are suppose } \\
\text { to hold twice the volume potentially } \\
\text { spilled. The } 340 \text { number makes sense as the } \\
\text { FHA assumes a spill of } 150 \text { gallons. }\end{array}$ & \\
\hline 8. & $\begin{array}{l}\text { Section } 9.2 .2 \mathrm{~B} .2 \text { - While the sprinklers do mitigate } \\
\text { a } 7 \text { ittle, could we add a phrase which states we do } \\
\text { not take credit for the sprinklers in the accident } \\
\text { analysis. This would eliminate any questions } \\
\text { whether the sprinklers are safety significant or } \\
\text { general service. The sprinklers are currently } \\
\text { general service and I would like to keep it that } \\
\text { way. }\end{array}$ & & $\begin{array}{l}\text { Text changed to state: Although not } \\
\text { specifically credited with preventing } \\
\text { collapse of the roof, the hot pipe. sprinkler } \\
\text { system also provides mitigation in the event } \\
\text { of a hydraulic oil fire. }\end{array}$ & \\
\hline 9. & $\begin{array}{l}\text { Section } 6.4 .1 .4 .4 \text {, paragraph Industrial Safety - } \\
\text { Gloveboxes have heat detectors only, no combustion } \\
\text { detectors. }\end{array}$ & & & \\
\hline
\end{tabular}




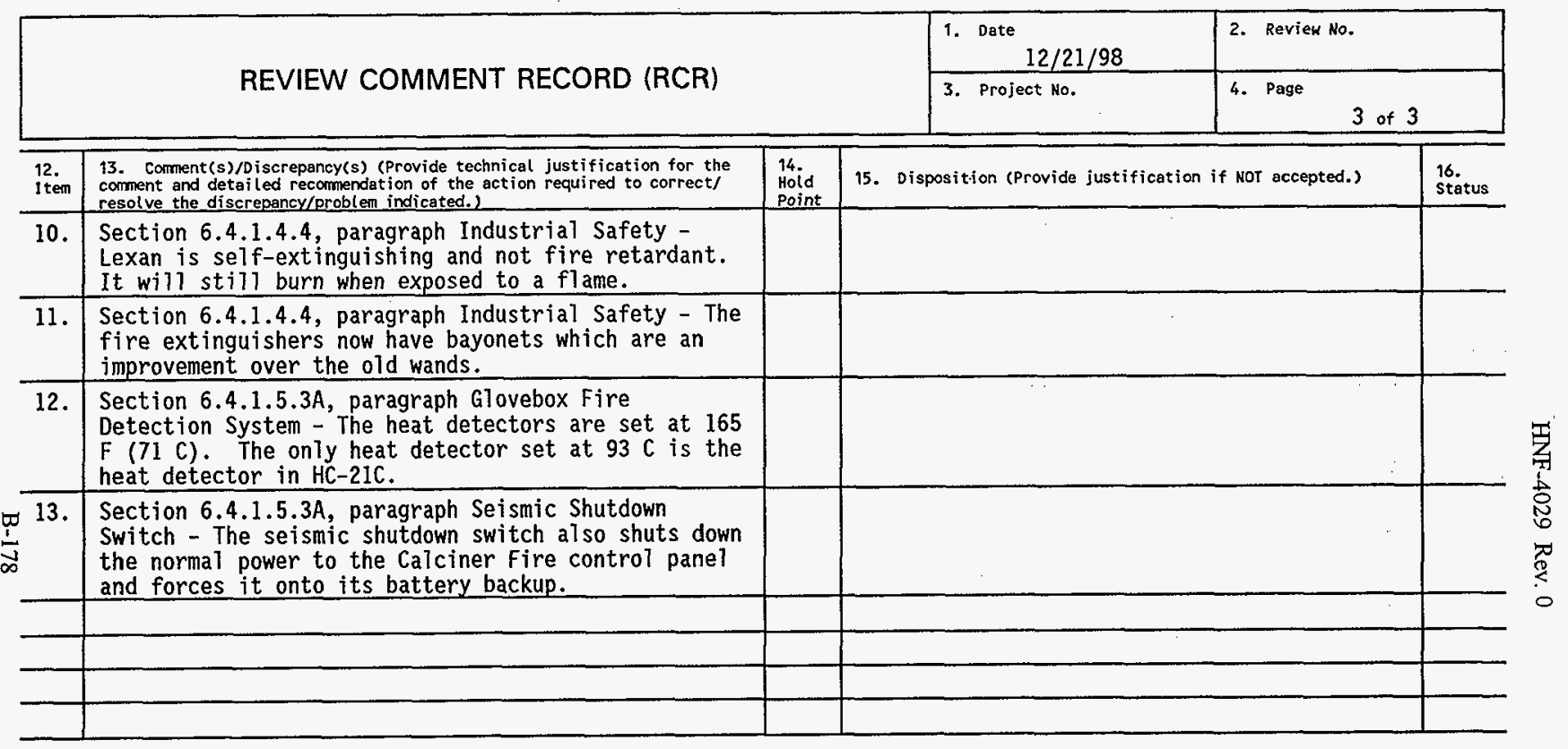


Rief, Gloria J

From:

Sent:

To:

Pickett, Rodney D

Wednesday, December 30, 1998 12:09 PM

Subject:

Rief, Gloria J

RE: RCR in WP5.1

Gloria,

Pass to Craig, the disposition looks fine.

Thanks,

Rodney Pickett

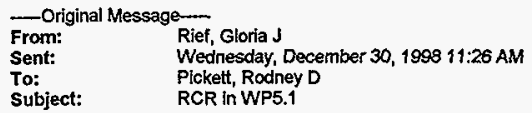

< File: PFP-RCR.RDP $\gg$ from Craig Carro 
REVIEW COMMENT RECORD (RCR)

\begin{tabular}{|l|l|}
\hline 1. Date & 2. Review No. \\
\hline 3. Project No. & 4. Page 2 of 11 \\
\hline
\end{tabular}

\begin{tabular}{|c|c|c|c|c|}
\hline $\begin{array}{c}12 . \\
\text { Item }\end{array}$ & $\begin{array}{l}\text { Comment(s)/Discrepancy(s) (Provide technical justification for the comment and detailed } \\
\text { recommendation of the action requircd to correct resolve the discrepancy/problem indicated.) }\end{array}$ & $\begin{array}{l}14 \\
\text { Hold } \\
\text { Point }\end{array}$ & Disposition (Provide justificaticn if NOT accepted.) & $\begin{array}{c}16 . \\
\text { Status }\end{array}$ \\
\hline$\overline{S I}$ & 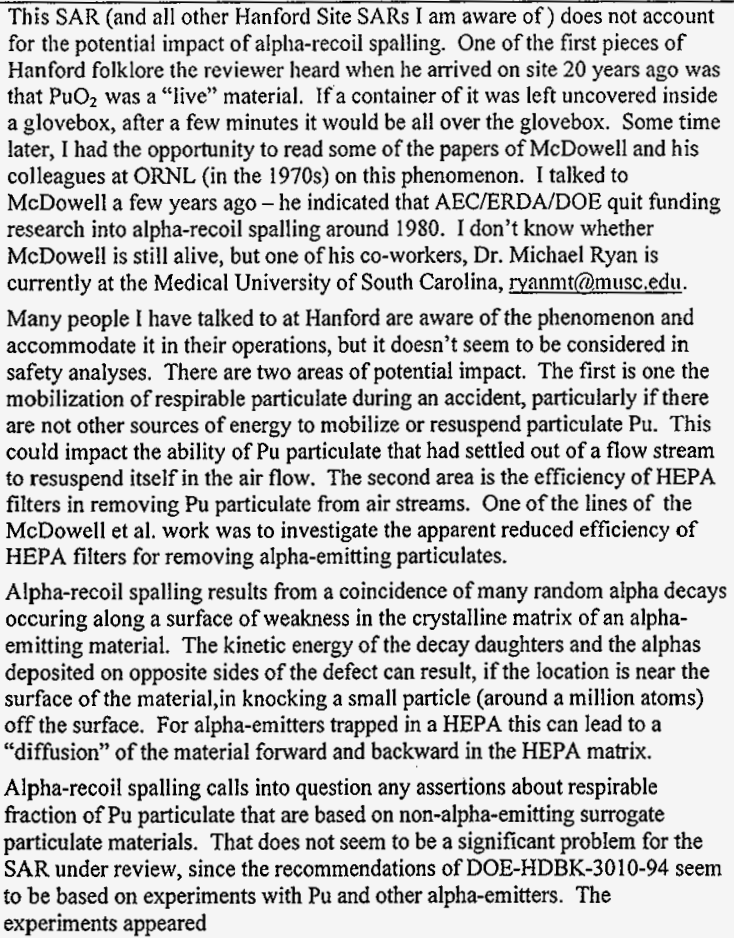 & & $\begin{array}{l}\text { The DOE handbook DOE-HDBK-3010-94 or its predecessors are } \\
\text { used to estimate airborne release fractions (ARFs) and respirable } \\
\text { fractions (RFS) in the PFP FSAR. Many of the ARFs and RFs used } \\
\text { are based on experiments performed specifically on Pu (such as } \\
\text { those used in the various fire scenarios). For release scenarios } \\
\text { where specific Pu ARFs are not available (e.g., resuspension } \\
\text { releases), very conservative ARFs and RFs from surrogates are } \\
\text { selected. The experiments on which the surrogate ARFs and RFs } \\
\text { were determined typically involved the use of ball milled powders } \\
\text { or other carefully prepared powders that were highly respirable and } \\
\text { often much lighter than Pu. Thus, the releases with Pu would be } \\
\text { expected to be much lower in actual accident scenarios than the } \\
\text { values suggested in the Handbook (ignoring, for now, the alpha } \\
\text { recoil issue). Typically, worst-case release fractions are combined } \\
\text { with worst-case respirable fractions in the Handbook. Hence, the } \\
\text { Handbook recommendations are considered to give highly } \\
\text { conservative resuits which should accommodate nominal airborne } \\
\text { Pu associated with alpha recoil. The DOE Handbook is the current } \\
\text { standard upon which the entire DOE complex estimates airborne } \\
\text { releases. We are aware of no documentation that suggests that the } \\
\text { ARFs recommended in the handbook are non conservative for Pu } \\
\text { because of the alpha recoil issue. Plant experience indicates that } \\
\text { alpha recoil is a mechanism for causing spread of contamination } \\
\text { within a plant, not a mechanism for causing gross airborne releases } \\
\text { that are comparable to the release estimates recommended in the } \\
\text { DOE handbook or other standards. We are also aware of no } \\
\text { references that indicate that the penetrations factors (PF) assumed } \\
\text { for HEPA filters based on aerosol testing are not appropriate for Pu } \\
\text { facilities. It is our position that the ARFs, RFs, and HEPA filter } \\
\text { PF=s used in the FSAR do not need to be revised to account for Pu } \\
\text { alpha recoil. }\end{array}$ & \\
\hline
\end{tabular}




\begin{tabular}{|l|l|l|l|l|}
\hline \multirow{2}{*}{ REVIEW COMMENT RECORD (RCR) } & 2. Rate & \\
\cline { 2 - 4 } & 3. Project No. & 4. Page \\
\hline
\end{tabular}

\begin{tabular}{|c|c|c|c|c|}
\hline $\begin{array}{l}12 . \\
\text { Item }\end{array}$ & $\begin{array}{l}\text { Comment(s)/Discrepancy(s) (Provide technical justification for the comment and detailed } \\
\text { recommendation of the action required to correct/resolve the discrepancy/problem indicated.) }\end{array}$ & $\begin{array}{c}14 . \\
\text { Hold } \\
\text { Point }\end{array}$ & $\begin{array}{l}15 . \\
\text { Disposition (Provide justification if NOT accepted.) }\end{array}$ & $\begin{array}{c}16 . \\
\text { Status }\end{array}$ \\
\hline $\begin{array}{c}\text { S1 } \\
\text { Cont }\end{array}$ & $\begin{array}{l}\text { to be based on experiments with alpha-emitting materials. The experiments } \\
\text { appear to be difficult and the results vary significantly from one experimenter } \\
\text { to another. Since the alpha-spalled particles are so small, some of the } \\
\text { experiments may not have been well designed to detect them. } \\
\text { Recommendation: review the literature on both aspects of this phenomenon to } \\
\text { establish whether the safety analyses need to be revised. }\end{array}$ & & . & \\
\hline S2. & $\begin{array}{l}\text { The TWRS Waste Storage SAR, currently under review by DOE-RL uses an } \\
\text { evaluation basis earthquake with peak horizontal ground acceleration of } 0.19 \mathrm{~g} \\
\text { and a return frequency of } 10^{-3} / y e a r \text {. It cites WHC-SD-W236A-TI-002 (Ch. } \\
1.0 \text {, Table } 1-32 \text { ) and DOE-STD-1020-94 as the basis for that choice. The PFP } \\
\text { SAR Rev } 1 \text { used a design basis earthquake of peak ground surface acceleration } \\
\text { of } 0.20 \mathrm{~g} \text { and a return frequency of } 10^{-4} / y e a r \text {. It cites Hanford Plant Standard } \\
\text { SDC } 4.1 \text { (WHC 1991). The choice of a return period of } 10,000 \text { years rather } \\
\text { than } 1,000 \text { years potentially affects the acceptability of some of the seismic } \\
\text { accident scenarios/sequences. } \\
\text { Recommendation: The PFP SAR analysts should review the situation to assure } \\
\text { that they are using the most recent Hanford Site seismic evaluation and should } \\
\text { assess the desirability of using assumptions consistent with those being used } \\
\text { for other SARs currently under production and review. }\end{array}$ & & $\begin{array}{l}\text { he Criteria Document for the } 1998 \text { update to the PFP FSAR, HNF- } \\
606 \text {, states that the update will employ the same format, } \\
\text { ethodology, and guidance used in preparing the original (Rev. 0-J) } \\
\text { SAR. Per the Criteria Document, the same risk evaluation criteria } \\
\text { sed in the original FSAR and cited in the PFP SER are to be used. } \\
\text { he magnitude and return frequency of the DBE are considered to be } \\
\text { uidance/criteria not to be deviated from in the } 1998 \text { update. No } \\
\text { hanges were therefore made to the text. }\end{array}$ & \\
\hline
\end{tabular}




\begin{tabular}{|l|l|l|l|l|l|l|}
\hline RI. Date & & \\
\hline 3. Project No. & & 4. Page \\
\hline
\end{tabular}

\begin{tabular}{|c|c|c|c|c|}
\hline $\begin{array}{ll}12 . \\
\text { Itern }\end{array}$ & $\begin{array}{l}13 . \\
\text { Comment(s)/Discrepancy(s) (Provide teclmical justification for the comment and detailed } \\
\text { recommendation of the action required to correct resolve the discrepancy/problem indicated.) }\end{array}$ & $\begin{array}{c}14 . \\
\text { Hold } \\
\text { Point }\end{array}$ & $\begin{array}{c}15 . \\
\text { Disposition (Provide justification if Norr accepted.) }\end{array}$ & $\begin{array}{ll}16 . \\
\text { Status }\end{array}$ \\
\hline S3. & $\begin{array}{l}\text { In what I reviewed I did not find a justification for the elimination of the roof } \\
\text { fire from the draft revision of the SAR. Table } 5-3 \text { describes the } 234-Z \\
\text { building roof as being "built-up" over a metal deck. I believe it is built-up } \\
\text { from combustible materials. } \\
\text { What has been considered is a hydraulic fluid fire resulting from leakage from } \\
\text { the hydraulic system used to operate the elevator. The postulated hydraulic } \\
\text { fluid fire can involve enough building columns to cause a roof collapse, and, } \\
\text { presumably, subsequent involvement of the roof materials in the fire. The } \\
\text { proposed mitigation, which apparently has already been implemented, is to } \\
\text { build a berm around the base of the elevator shaft in order to limit the size of } \\
\text { the pool of burning hydraulic fluid and thereby limit the number of building } \\
\text { structural columns involved in the fire } \\
\text { Since the hydraulic system, of necessity, is a pressurized system, the analysis } \\
\text { of a hydraulic fluid fire needs to consider the possibility of a spray leak from } \\
\text { the system that creates a pool outside the bermed area, with a resulting fire } \\
\text { whose pool area is not limited by the berm. } \\
\text { Recommendation: Evaluate the possibility of a hydraulic spray leak bypassing } \\
\text { the berm, with a resulting fire that threatens the structural integrity of the } \\
\text { building. Include an analysis of the roof fire or establish rigorously that it } \\
\text { cannot ("i.e., extremely unlikely) occur. }\end{array}$ & & $\begin{array}{l}\text { In response to the reviewer's comment, the plant will enclose the } \\
\text { approximate } 2 \mathrm{ft} \text { pipe run vulnerable to a spray release. }\end{array}$ & \\
\hline
\end{tabular}




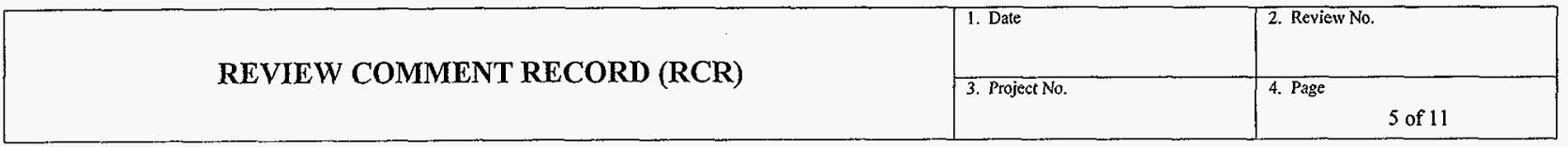

\begin{tabular}{|c|c|c|c|c|}
\hline $\begin{array}{c}12 . \\
\text { Iten }\end{array}$ & $\begin{array}{l}13 \text {. } \\
\text { Comment(s)/Discrepancy(s) (Provite teclinical justification for the comment and detailed } \\
\text { recommendation of the action required to correct/ resolve the discrepancy/problem indicated.) }\end{array}$ & $\begin{array}{c}14 . \\
\text { Ifold } \\
\text { Point }\end{array}$ & $\begin{array}{l}15 . \\
\text { Disposition (Provide justification if NOT accepted.) }\end{array}$ & $\begin{array}{c}16 . \\
\text { Status }\end{array}$ \\
\hline S4. & 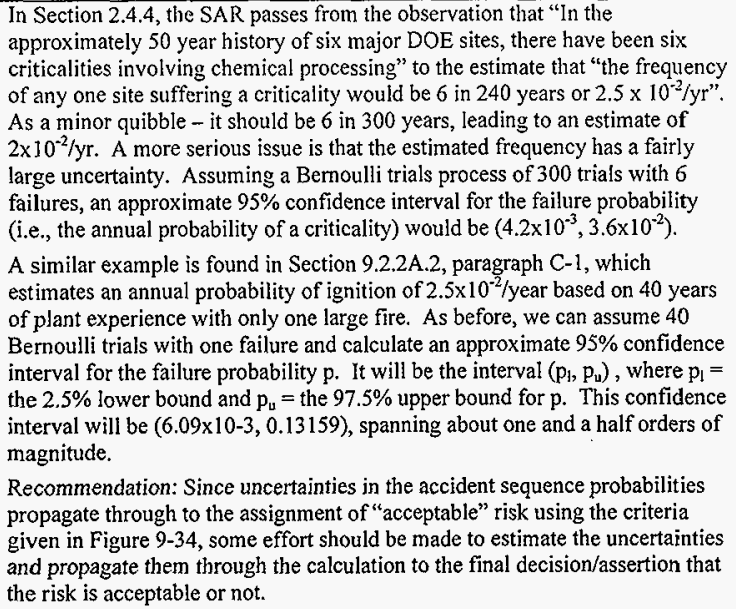 & & $\begin{array}{l}\text { Concur with reviewer's comment that uncertainties in the accident } \\
\text { sequence probabilities propagate through to the assignment of } \\
\text { acceptable risk. However, the current methodology is to assign } \\
\text { point estimates that are believed to be conservative. } \\
\text { Approximately } 10 \text { years ago a concerted effort was made to } \\
\text { prepare event trees and fault trees for all accident analyses and, to } \\
\text { the extent data was available, to assign and propagate the } \\
\text { uncertainties. There was considerable dispute as to the adequacy } \\
\text { and/or applicability of equipment failure rate and human error } \\
\text { probability data bases as well as to assumptions related to } \\
\text { distributions and calculational methodology. Such disputes were } \\
\text { nof limited to the Hanford Site (e.g., at Rocky Flats there was } \\
\text { disagreement among experts regarding the issues as DOE struggled } \\
\text { to authorize restart of thee Building } 559 \text { ). By inspection, it was } \\
\text { concluded that, although assumptions can be made and numbers } \\
\text { calculated, a more practical and appropriate approach for the } \\
\text { bounding accident scenarios analyzed in nuclear facility SARs is to } \\
\text { conservatively assign point estimates. }\end{array}$ & \\
\hline S5. & $\begin{array}{l}\text { It is not clear to the reviewer why bone surface has been used as the } \\
\text { controlling organ for Pu inhalation dose. Although bone surface appears to be } \\
\text { where radium ends up, my impression was that Pu ended up in the interior of } \\
\text { the bone, where bone red marrow would be a more appropriate controlling } \\
\text { organ. Since bone marrow makes a significantly larger contribution to whole } \\
\text { body EDE in the recent ICRP formulations than bone surface, the use of bone } \\
\text { marrow as controlling organ might have a significant impact on the } \\
\text { acceptability of some of the accident consequences. } \\
\text { Recommendation: Verify with appropriate health physics experts whether } \\
\text { bone surface or bone marrow is the correct controlling organ for Pu and Am } \\
\text { exposure. }\end{array}$ & & $\begin{array}{l}\text { Our resident Certified Health Physicist confirmed that the limiting } \\
\text { organ for } \mathrm{Pu} \text { and Am radionuclides of interest is the bone surface. } \\
\text { This is also shown to be the case in the document used for dose } \\
\text { conversion factors, EPA-520, Federal Guidence No. } 11 \text {. }\end{array}$ & \\
\hline
\end{tabular}




\begin{tabular}{|l|l|l|l|}
\hline REVIEW COMMENT RECORD (RCR) & 1. Date Review No. \\
\cline { 2 - 3 } & 3. Project No. \\
\hline
\end{tabular}

\begin{tabular}{|c|c|c|c|c|}
\hline $\begin{array}{c}12 . \\
\text { Item }\end{array}$ & $\begin{array}{l}13 . \\
\text { Comment(s)/Discrepancy)(s) (Provide techmical justification for the comment and detailed } \\
\text { recommendation of the action required to correct resolve the discrepancy/problem indicated.) }\end{array}$ & $\begin{array}{l}14 . \\
\text { Ilold } \\
\text { Point }\end{array}$ & $\begin{array}{c}15 . \\
\text { Disposition (Provide justification if NOT accepted.) }\end{array}$ & $\begin{array}{c}16 . \\
\text { Status }\end{array}$ \\
\hline 56. & 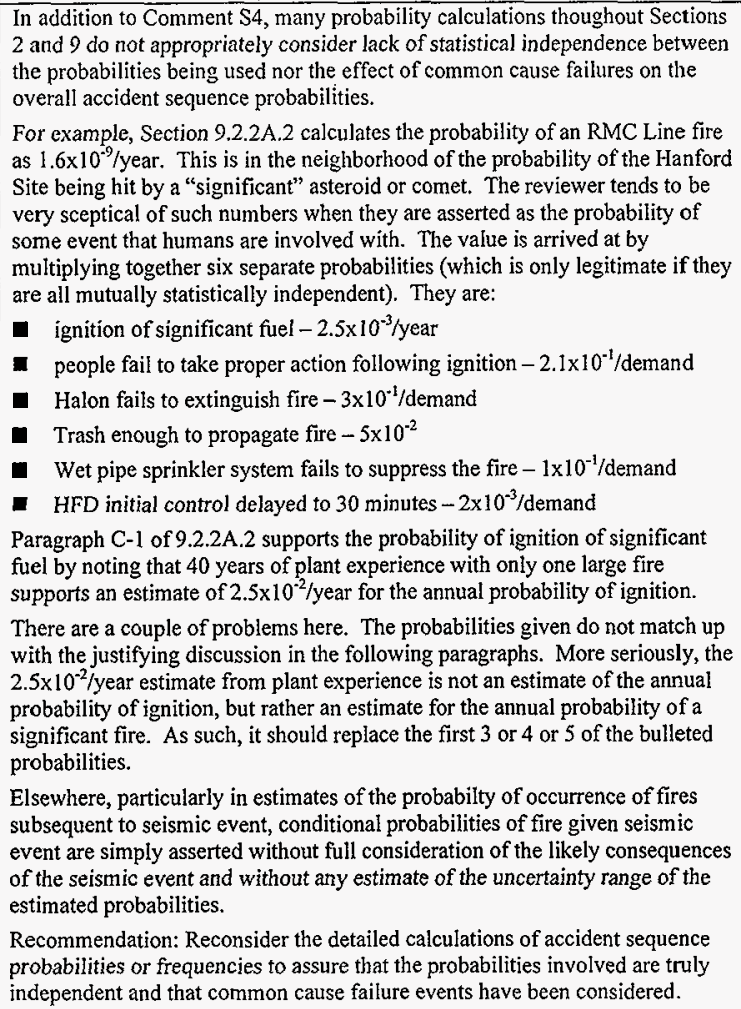 & & $\begin{array}{l}\text { In light of the reviewer's comment Re independent events, analysts } \\
\text { have re-examined their respective probability arguments to ensure } \\
\text { independent events. The RMC Line fire probability estimate was } \\
\text { revised to combine events C-1 (ignition of significant fuel) and C-4 } \\
\text { (trash enough to propagate fire). The value for C-1 has been } \\
\text { conservatively applied. }\end{array}$ & \\
\hline
\end{tabular}




\begin{tabular}{|l|l|l|}
\hline \multirow{2}{*}{ REVIEW COMMENT RECORD (RCR) } & 1. Date & 2. Review No. \\
\cline { 2 - 3 } & 3. Project No. & 4. Page \\
\hline
\end{tabular}

\begin{tabular}{|c|c|c|c|c|c|}
\hline & $\begin{array}{c}12 . \\
\mathrm{Itcm}\end{array}$ & 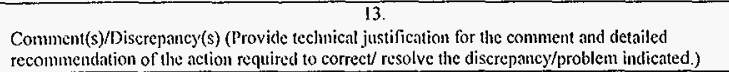 & $\begin{array}{l}14 . \\
\text { Hold } \\
\text { Hoint }\end{array}$ & $\begin{array}{l}15 . \\
\text { Disposition (Providc justification if NOT accepted.) }\end{array}$ & $\begin{array}{cl}16 . \\
\text { Status } \\
\end{array}$ \\
\hline & S7 & $\begin{array}{l}\text { The analysis in Section } 9.2 .9 .3 .4 \text { of the consequences of a compressed gas } \\
\text { bottle becoming a missle ought to consider the possibility of a tortuous path } \\
\text { (gas cylinders and kids balloons are notorious for the unpredictability of their } \\
\text { trajectories) that results in the cylinder bypassing the } 8 \text { " walls surrounding } \\
\text { Rooms } 228 \text { and } 230 \text { by going up through the ceiling and back down into } 228 \\
\text { or } 230 \text { or down through the floor and back up through the floor into } 228 \text { or } \\
230 \text {. }\end{array}$ & & $\begin{array}{l}\text { The cylinder could not penetrate through the floor and come up } \\
\text { inside the RMC line area because there is no tunnel or rooms } \\
\text { beneath the RMC line area and the cylinder conldn=t penetrate } \\
\text { through the basemat of the facility. However, there is a potential } \\
\text { for the cylinder to break through into the duct level and cause } \\
\text { damage not acknowledged in the current writeup. The vertical } \\
\text { denitration calcination process is not authorized for use by this } \\
\text { FSAR update. Although Section 9.2.9.3.4 was not changed and is } \\
\text { outside the scope of review for this undate, text will be added to } \\
\text { the writeup to acknowledge potential damage in the duct level and } \\
\text { to commit to further examination of that damage potential in a } \\
\text { future update to the SAR that authorizes use of the VDC. }\end{array}$ & \\
\hline & $\overline{\$} 8$ & $\begin{array}{l}\text { The risk acceptance criteria used in this revision of the SAR is described in } \\
\text { Section } 9.4 .2 \text { and Figure } 9-34 \text {. The TWRS Waste Storage SAR, currently } \\
\text { under review by DOE/RL uses a step function version of these criteria rather } \\
\text { than the piecewise linear curves given in Figure 9-34. Several of the PFP } \\
\text { SAR accidents would fall on or just above the risk acceptance criteria being } \\
\text { used by the TWRS contractor. I haven't had a chance to compare the } \\
\text { justification that each organization offers for its choice of acceptance criteria. }\end{array}$ & & $\begin{array}{l}\text { The Criteria Document for the } 1998 \text { FSAR update, HNF-3606, } \\
\text { pecifically requires that the risk evaluation guidelines from the } \\
\text { riginal Rev. O-J of the FSAR be used in the } 1998 \text { update. }\end{array}$ & \\
\hline
\end{tabular}




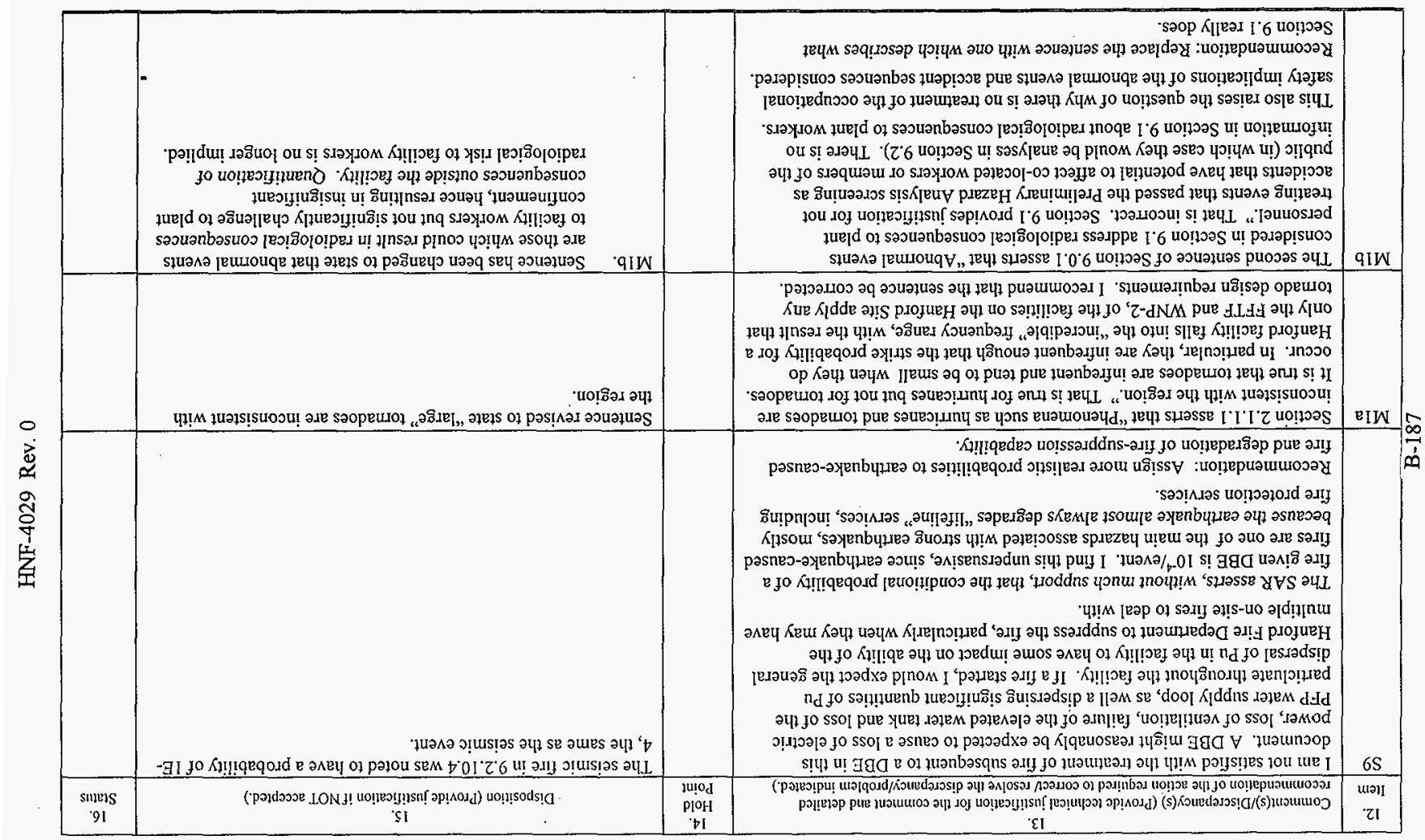

\begin{tabular}{|c|c|c|}
\hline [I J0 8 & ON ToOFod $\varepsilon$ & (YרY) \\
\hline ON Mว!nวу $\tau$ & गुएव 'I & \\
\hline
\end{tabular}




\begin{tabular}{|l|l|l|l|}
\hline REVIEW COMMENT RECORD (RCR) & 1. Date & \\
\cline { 1 - 2 } & 3. Project No, & 4. Page \\
\hline
\end{tabular}

\begin{tabular}{|c|c|c|c|c|}
\hline $\begin{array}{c}12 . \\
\text { Item }\end{array}$ & $\begin{array}{l}13 \text {. } \\
\text { Comment(s)/Discrepancy(s) (Provide technical justification for the comment and detailed } \\
\text { recommendation of the action required to correct/ resolve the discrepancy/problem indicated.) }\end{array}$ & $\begin{array}{l}14 . \\
\text { Hold } \\
\text { Point } \\
\end{array}$ & $\frac{15}{\text { Disposition (Provide justification if NOT accepted.) }}$ & $\begin{array}{c}16 . \\
\text { Status }\end{array}$ \\
\hline $\mathrm{M} 2$ & $\begin{array}{l}\text { The discussion of the RMC Line Fire and its impact on the HEPA filters in } \\
\text { Sections } 9.2 .2 \mathrm{~A} \text { and } 9.2 .2 \mathrm{~A} .1 \text { needs to be corrected. The fuel loading is } \\
\text { asserted to be } 1000 \mathrm{~kg} \text { of plastic, equivalent to } 2790 \mathrm{~kg} \text { of wood ( } 6160 \mathrm{lb} \text { of } \\
\text { wood). The PFP FHA is quoted as saying that burning of } 55 \mathrm{lb} \text { of wood can } \\
\text { potentially clog (reduce airflow by } 50 \% \text { ) a } 24 \text { " } \times 24 \text { " HEPA filter. Therefore } \\
\text { it would require approximately } 7000 \mathrm{lb} \text { of wood to clog all } 128 \text { of the E-4 } \\
\text { filter room HEPAs. Finally, the SAR asserts that } 7000 \mathrm{lb} \text { of wood is } 2.5 \text { times } \\
\text { the quantity of combustible in Room } 228 \text { and concludes "Accordingly, ... the } \\
\text { E-4 filters would not be affected by smoke." The } 7000 \mathrm{lb} \text { of wood is more } \\
\text { like } 1.15 \text { times the combustible in Room } 228 \text {. } \\
\text { So, the value " } 2.5 \text { " needs to be corrected to } 1.15 \text { and some consideration } \\
\text { should be given to the implications of "almost" clogging all of the E-4 HEPA } \\
\text { filters. In particular, at what point does that hot smoke and combustion gases } \\
\text { and entrained particulate start looking for an easier way to get out of the } \\
\text { building, such as reverse flow through the supply duct and out through the } \\
\text { roughing filters (not HEPAs) at the supply inlet. Another consideration is the } \\
\text { effect of clogging of the non-testable HEPAs directly outside the gloveboxes } \\
\text { in the ductwork leading to the E-4 HEPA fitters. What happens to the smoke, } \\
\text { etc. and the pathway to E-4 if those filters clog? } \\
\text { Recommendation: Correct the typo and consider the potential for reverse flow } \\
\text { during an RMC Line fire and the implications of that reverse flow for Pu } \\
\text { releases to the environment. }\end{array}$ & & $\begin{array}{l}\text { Corrections made per comment. Reverse flow is currently } \\
\text { evaluated (i.e., exhaust via the E-3 system). }\end{array}$ & \\
\hline
\end{tabular}




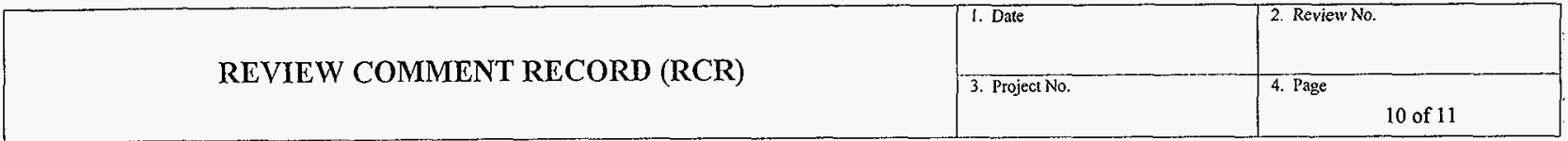

\begin{tabular}{|c|c|c|c|c|}
\hline $\begin{array}{l}12 . \\
\text { Item }\end{array}$ & $\begin{array}{l}\text { Comment(s)/Discrepancy(s) (Provide teclunical justification for the comment and detailed } \\
\text { recommendation of the action required to correct resolve the discrepancy/problem indicated.) }\end{array}$ & $\begin{array}{l}14 . \\
\text { Hold } \\
\text { Point }\end{array}$ & Disposition (Provide justification if NOT accepted.) & $\begin{array}{c}16 . \\
\text { Statis }\end{array}$ \\
\hline$\overline{M 3}$ & $\begin{array}{l}\text { a. Section } 9.2 .4 .0 \text { contains the asscrtions: "The probability of the aggregate } \\
\text { of these selected, specific, simultaneous failures in combination with the } \\
\text { earthquake is extremely low. However, this cannot be proven." This ought to } \\
\text { be reworded so that it is not baldly asserting something that cannot be proven. } \\
\text { Perhaps "We believe that the probability ...". } \\
\text { b. Similarly, on page } 9-163 \text {, it is asserted that "The damage will be described } \\
\text { on a room-by-room basis with the description centering on those events that } \\
\text { can result in the dispersal of plutonium of toxic materials (including inert } \\
\text { gases). This is not the only damage that could occur in an earthquake, but it is } \\
\text { the only damage of interest for the FSAR." I would argue that damage that } \\
\text { can initiate a fire or create the conditions for propagation of a fire or make it } \\
\text { more difficult to suppress a fire is of considerable interest, even if it occurs } \\
\text { somewhere where there is not any immediate release of Pu or toxic materials. } \\
\text { c. Finally, toward the bottom of page 9-164, appears the phrase "The } \\
\text { qualitative arguments are meant to show the obvious and are therefore } \\
\text { unsupported." Section } 9 \text { has too many unsupported qualitative and } \\
\text { quantitative arguments that did not seem obvious to this reviewer. }\end{array}$ & & $\begin{array}{l}\text { a. Reworded paragrapli so that it no longer asserts things that } \\
\text { can't be proven. } \\
\text { b. Added sentence on } \mathrm{Pg} 9-163 \text { that states that seismic induced } \\
\text { fires in gloveboxes are considered later. } \\
\text { c. Sentence in question has been deleted. }\end{array}$ & \\
\hline M4 & $\begin{array}{l}\text { On page 9-195, in the course of an argument that an RMC Line fire would not } \\
\text { involve the whole line appears the assertion "There is a large quantity of metal } \\
\text { within the boxes which would help absorb heat." Although metals have high } \\
\text { heat conductivity, their heat capacity is generally low by comparison with } \\
\text { water and carbonaceous materials. As a result, they will heat up quickly, NOT } \\
\text { absorbing much heat, and may reach a high enough temperature to provide an } \\
\text { ignition source for further spread of the fire. } \\
\text { Recommendation: I suggest deleting the sentence. }\end{array}$ & & Sentence deleted as suggested. & \\
\hline M5 & $\begin{array}{l}\text { Regarding the arguments in Section } 9.2 .7, \text { I would note the near collision of a } \\
\text { light plane and a commuter aircraft over what appeared from news accounts to } \\
\text { be the western part of the Hanford Site probably on federal airway V } 204 \text {. } \\
\text { Section } 9.2 .7 .1 .1 \text { promises that Section } 9.2 .7 .1 .5 \text { will give the distances to all } \\
\text { airports, but } 9.2 .7 .1 .5 \text { doesn't deliver. No resolution required. }\end{array}$ & & $\begin{array}{l}\text { No resolution required. Will consider adding distances to airports } \\
\text { in future revision to the FSAR. }\end{array}$ & \\
\hline
\end{tabular}




\begin{tabular}{|c|l|l|l|l|}
\hline REVIEW COMMENT RECORD (RCR) & & 1. Date & \\
\cline { 2 - 4 } & 3. Project No. & 4. Page \\
\hline
\end{tabular}

\begin{tabular}{|c|c|c|c|c|}
\hline $\begin{array}{c}12 . \\
\text { Item }\end{array}$ & $\begin{array}{l}13 . \\
\text { Commenu(s)/Discrepancy(s) (Provide tecinical justification for the comment and detailed } \\
\text { recommendation of the action required to correct/ resolve the discrepancy/problem indicatedi.) }\end{array}$ & $\begin{array}{c}14 . \\
\text { Hold } \\
\text { Point }\end{array}$ & Disposition (Provide justification if Nor accepted) & $\begin{array}{l}16 . \\
\text { Status }\end{array}$ \\
\hline $\mathrm{Tl}$ & 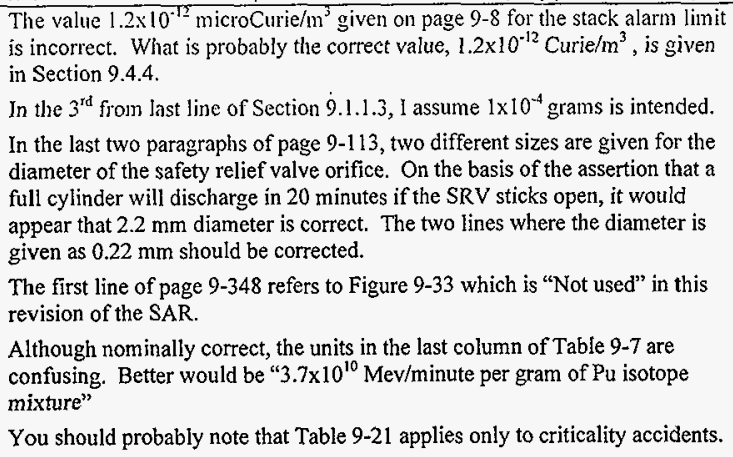 & & $\begin{array}{l}\text { Suggested changes have been incorporated. Figure } 9-3 \overline{3} \text { has been } \\
\text { added back into the document. }\end{array}$ & \\
\hline
\end{tabular}




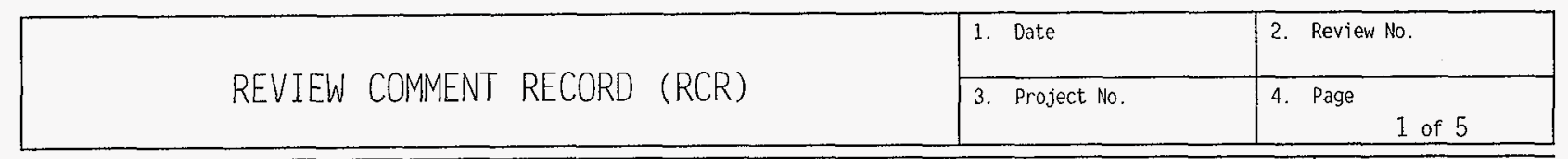

5. Document Number(s)/Title(s)

HNF -SD-CP-SAR-021

6. Program/Project/ Building Number PFP SAR

\section{Reviewer JSPuk elows $\mathrm{R}(\mathrm{R})$}

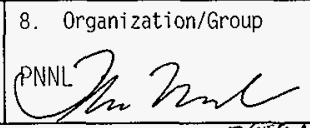

9. Location/Phone

EESB $1234 / 372-$ 4074

\begin{tabular}{|c|c|c|c|c|}
\hline $\begin{array}{l}12 . \\
\text { Ite } \\
\text { m }\end{array}$ & $\begin{array}{l}\text { 13. Comment(s)/Discrepancy(s) (Provide technical justification } \\
\text { for the comment and detailed recommendation of the action required } \\
\text { to correct/ resolve the discrepancy/problem indicated.) }\end{array}$ & $\begin{array}{l}14 \text { id } \\
\text { Hold } \\
\text { Point }\end{array}$ & $\begin{array}{l}\text { 15. Disposition (Provide justification if NOT } \\
\text { accepted.) }\end{array}$ & $\begin{array}{l}16 . \\
\text { Statu } \\
\end{array}$ \\
\hline 0 & 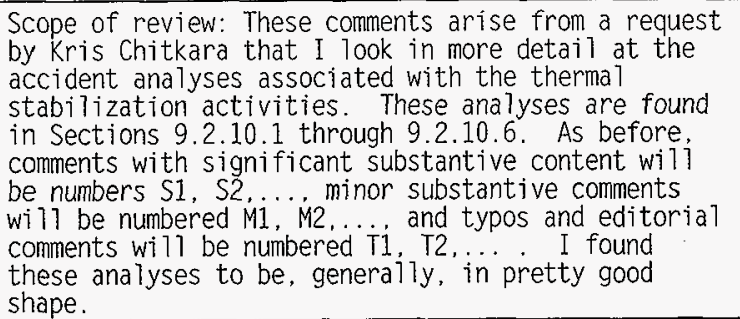 & & & \\
\hline
\end{tabular}




\begin{tabular}{|l|l|l|l|}
\hline \multirow{2}{*}{ REVIEW COMMENT RECORD (RCR) } & 1. Date & Review No. \\
\cline { 2 - 3 } & 3. Project No. & 4. Page \\
\hline
\end{tabular}

12. 13. Comment(s)/Discrepancy(s) (Provide technical justification

Ite for the comment and detailed recommendation of the action required $\mathrm{m}$ to correct/ resolve the discrepancy/problem indicated.)

S1 I $^{\text {st }}$ text paragraph of page 9-323: I am uncomfortable with the extrapolation from data for time to ignition of polycarbonate for heat fluxes at $40 \mathrm{~kW} / \mathrm{m}^{2}$ and $70 \mathrm{~kW} / \mathrm{m}^{2}$ to a time for ignition at a heat flux of $168 \mathrm{~kW} / \mathrm{m}^{2}$. The extrapolation is linear in a $\log -70 \mathrm{~g}$ representation of the known data, which implies a power law for the relationship between heat flux applied and time to ignition. Since the relevant chemical kinetics probably have a rate that is an exponential function of the reaction temperature, it is not clear to me that a power law relationship between these variables is appropriate. of power law extrapolation in this context.

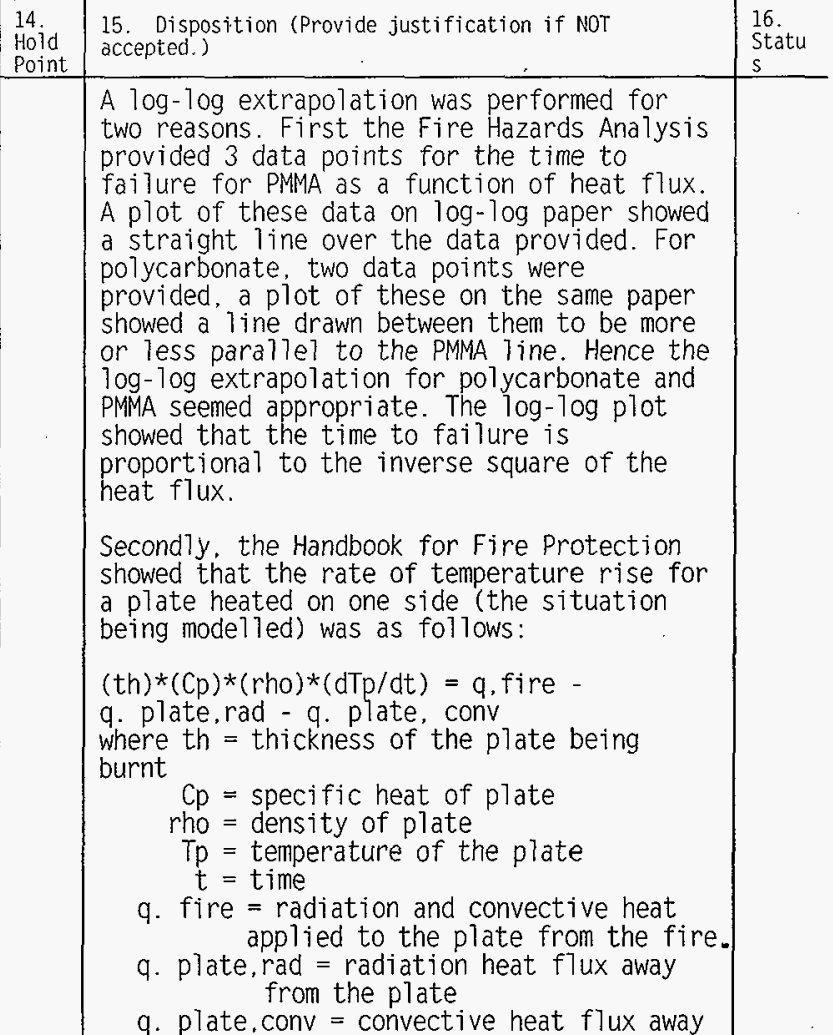




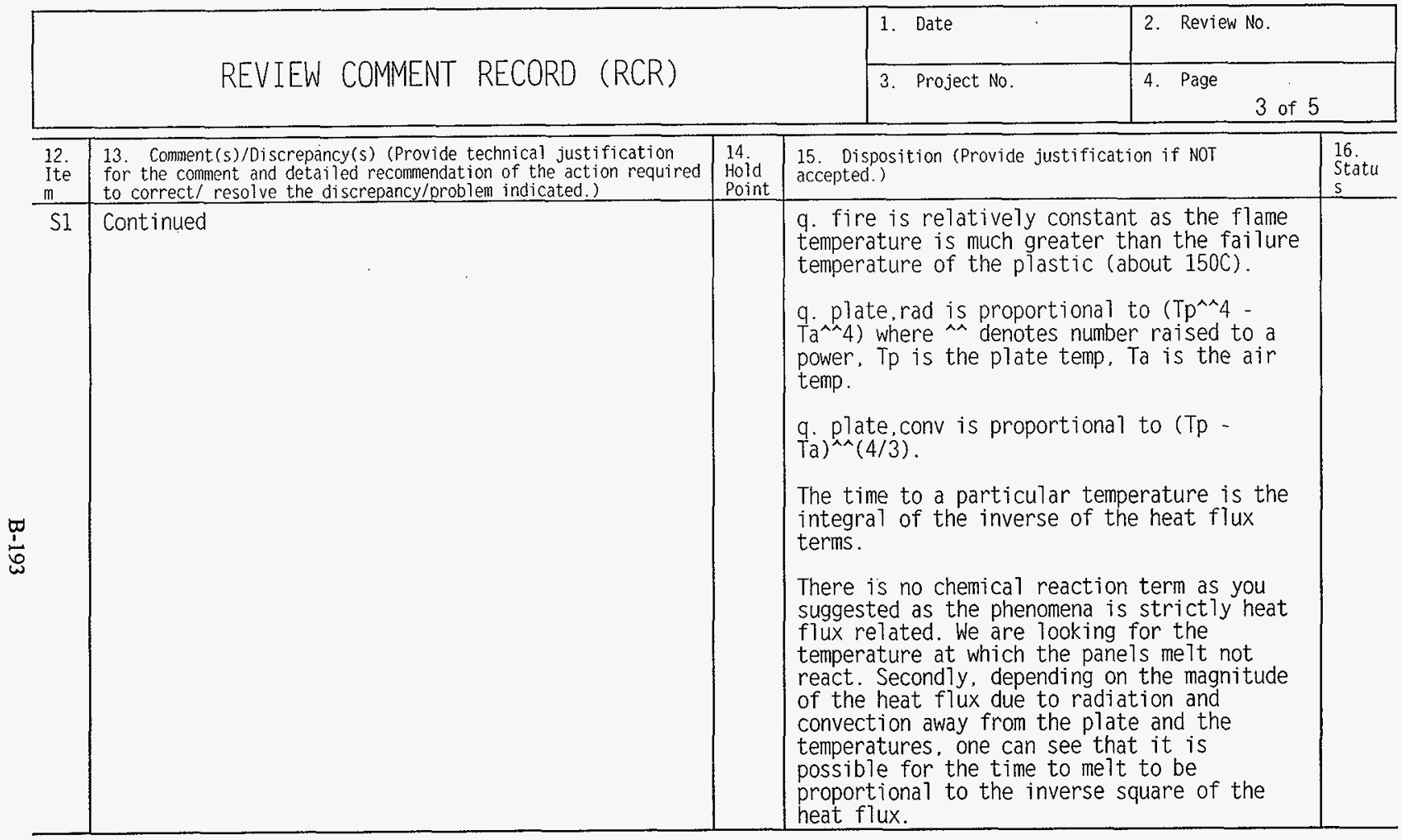




\begin{tabular}{|l|l|l|l|}
\hline & 1. Date & Review No. \\
\cline { 2 - 3 } & REVIEW COMMENT RECORD (RCR) & Project No. \\
\hline
\end{tabular}

\begin{tabular}{|c|c|c|c|c|}
\hline $\begin{array}{l}12 . \\
\text { lte } \\
\text { m }\end{array}$ & $\begin{array}{l}\text { 13. Comment(s)/Discrepancy(s) (Provide technical justification } \\
\text { for the comment and detailed recommendation of the action required } \\
\text { to correct/ resolve the discrepancy/problem indicated.) }\end{array}$ & $\begin{array}{l}14 . \\
\text { Hoid } \\
\text { Point }\end{array}$ & $\begin{array}{l}\text { 15. Disposition (Provide justification if nOT } \\
\text { accepted.) }\end{array}$ & $\begin{array}{l}16 . \\
\text { Statu } \\
\text { S }\end{array}$ \\
\hline 52 & $\begin{array}{l}\text { Section } 9.2 .10 .4 .2 \text { argues that there is no dose } \\
\text { resulting from a seismic-induced fire in glovebox } \\
\text { HC-21C in the no-ventilation case, because there is } \\
\text { "no air flow path from room } 230 \mathrm{~A} \text { in a seismic } \\
\text { event". My memory of the layout of room } 230 \mathrm{~A} \text { is } \\
\text { that the air supply grills are high on the walls and } \\
\text { the exhaust grills are near the floor. In the event } \\
\text { of a fire with stagnant conditions. I would expect } \\
\text { to see, at least locally, hot combustion gases } \\
\text { exiting } 230 \mathrm{~A} \text { to the supply side ductwork above and } \\
\text { cool replacement air entering near the floor through } \\
\text { the (normal) exhaust ductwork. I recognize that } \\
\text { there is a lot of space on the ductwork floor for } \\
\text { the hot gas and smoke to wander around and get lost } \\
\text { without exiting the building, but I am not convinced } \\
\text { by the assertion that there is "no air flow path" to } \\
\text { the outside. }\end{array}$ & & $\begin{array}{l}\text { The reason that there is no air flow through } \\
\text { Room } 230 \text { A for the "No vent" case is that the } \\
\text { room is surrounded by a seismically } \\
\text { qualified concrete wall that extends up into } \\
\text { the duct level to the floor of the 3rd } \\
\text { level. Since the walls are qualified, it was } \\
\text { argued that the doors in the walls would } \\
\text { remain shut during and after a seismic } \\
\text { event. The "No vent" case assumed that the } \\
\text { ventilation flow failed and that aerosol } \\
\text { transport through the building was from } \\
\text { outside air flowing through the open doors } \\
\text { within the building and on the exterior. } \\
\text { Since there are no doors open in the area of } \\
\text { Room } 230 \text { a. there is no flow in this case. } \\
\text { While there might be flow from the room into } \\
\text { the duct level. the duct leve? walls being } \\
\text { qualified precludes flow out into the rest } \\
\text { of the duct level. }\end{array}$ & \\
\hline & & & & \\
\hline & & & & \\
\hline
\end{tabular}




\begin{tabular}{|l|l|l|l|l|}
\hline REVIEW COMMENT RECORD (RCR) & 1. Date & Review No. \\
\cline { 2 - 4 } & 3. Project No. & 4. Page \\
\hline
\end{tabular}

12 13. Comment(s)/Discrepancy(s) (Provide technical justification

Ite for the comnent and detailed recommendation of the action required

$\mathrm{m}$ to correct/ resolve the discrepancy/problem indicated.)

M1 At the top of page 9-296, ice storms, range fires, and grid collapses can be added to the list of causes of loss of electrical power.

In the paragraphs on Range Fires, you might add as the major mechanism by which range fires can cause electrical outages the fact that electrically. conductive smoke and combustion gases can cause power lines to short to ground as the range fire burns through underneath the power lines. The shorting to ground of major transmission lines can cause cascading outages as protective devices trip various generators and transmission line segments $\varpi \quad$ off line to protect them from the effects of the 范 $\quad \begin{aligned} & \text { cause the two great U.S. Western Power Grid outages } \\ & \text { in } 1996 \text {. }\end{aligned}$

M2 In the paragraph on Uncontrolled Fire in Glovebox in the middle of page $0-299$, plexiglass and Lexan panels can be added to the list glovebox combustibles.

M3 In the $3^{\text {rd }}$ line of Section 9.2.10.2.2 and the last line of the $1^{\text {st }}$ paragraph: I con't like to see the words "assure", "ensure", "prevent", guarantee", etc. associated with procedural and administrative controls. Properly designed and implemented they may reduce accident sequence probabilities significantly, but there wi11 always be occasional failures of such controls. If you write and say "assure", etc. too often, people may start believing it.

T1 The equation in the middle of page 9-313: the units on $V$ should be $\mathrm{ft}^{3}$. as they are on the next line.

\begin{tabular}{|c|c|c|}
\hline $\begin{array}{l}14 . \\
\text { Hoid } \\
\text { Point }\end{array}$ & $\begin{array}{l}\text { 15. Disposition (Provide justification if NOT } \\
\text { accepted.) }\end{array}$ & $\begin{array}{l}16 . \\
\text { Statu } \\
\text { s }\end{array}$ \\
\hline & $\begin{array}{l}\text { Added additional causes for loss of power to } \\
\text { the paragraph. } \\
\text { Shorting to ground added as potential } \\
\text { mechanism for power loss in range fire } \\
\text { discussion. }\end{array}$ & \\
\hline & $\begin{array}{l}\text { Modified sentence in middle of paragraph to } \\
\text { clarify that Lexan and Lucite viewing panels } \\
\text { add significant quantity of combustibles. }\end{array}$ & \\
\hline & $\begin{array}{l}\text { Your suggestion that the word "ensure" be } \\
\text { removed was considered, but I took no } \\
\text { action. In my view, proper air flow does } \\
\text { ensure combustion. A change was made } \\
\text { regarding the second part of the comment. } \\
\text { The word "assure" was changed to "checked" } \\
\text { as that is what the operator does. }\end{array}$ & \\
\hline & change made, thanks. & \\
\hline
\end{tabular}




\section{REVIEW COMMENT RECORD (RCR)}

1. Date $1 / 13199$ PFP FSAR
2. Review No.

4. Page 1

1 of 2

5. Document Number(s)/Title(s)

HNF-SD-CP-SAR-021

17. Comment Submittal Approval:

Organization Manager (Optional)

6. Program/Project/ Bui lding Number

PFP SAR

7. Reviewer
Dick. Johnny D

8. Organization/Group

BWHC/PFP Facilities Systems Engineering
9. Location/Phone

$\mathrm{M} 0032 / 200 \mathrm{~W} / 373$ 4180

10. Agreement with indicated comment disposition(s) 11. CLOSED Date 199 buotifoll tor gohn Dik Buthor/originator
Date
Dut thall for gohm Dich Reviewer/Point of Contact Sort fted Author/originator

\begin{tabular}{|c|c|c|c|c|}
\hline $\begin{array}{l}12 . \\
\text { Ite } \\
m\end{array}$ & $\begin{array}{l}\text { 13. Comment(s)/Discrepancy(s) (Provide technical justification } \\
\text { for the comment and detailed recommendation of the action required } \\
\text { to correct/ resolve the discrepancy/probjem indicated.) }\end{array}$ & $\begin{array}{l}14 \\
\text { Hoid } \\
\text { Point } \\
\end{array}$ & $\begin{array}{l}\text { 15. Disposition (Provide justification if NOT } \\
\text { accepted.) }\end{array}$ & $\begin{array}{l}16 \\
\text { Statu } \\
\text { s }\end{array}$ \\
\hline 1. & $\begin{array}{l}\text { Page 9-81, Section 9.1.7E.1.4. Statement is not } \\
\text { true. There are five gauges available to measure } \\
\text { exhaust vault DP with respect to the bui lding (DPI- } \\
\text { D4-241Z, DPI-D5-241Z, DPI-D6-2412, and DPI-D8-241Z). } \\
\text { In addition these gauge are part of the plant's } \\
\text { routine surveillance program. }\end{array}$ & & $\begin{array}{l}\text { Accepted. Section } 9.1 .7 E .1 .4 \text { has been } \\
\text { rewritten to identify the five DP gauges. }\end{array}$ & \\
\hline & & & & \\
\hline & & & & \\
\hline & & & & \\
\hline & & & & \\
\hline & & & & \\
\hline & & & & \\
\hline & & & & \\
\hline & & & & \\
\hline & & & $\bullet$ & \\
\hline & & & & \\
\hline & & & & \\
\hline
\end{tabular}


HNF-4029 Rev. 0

\section{Hall, Brett W}

From:

Sent:

To:

Subject:
Dick, Johnny D

Thursday, January 14, 1999 7:52 AM

Hall, Brett W

RE: RCR Comment

Brett $_{1}$

I have reviewed the attached RCR and agree with the disposition.

Thanks

John

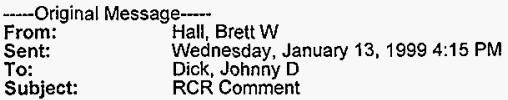

John,

We're trying to finish up Rev. 1 of the PFP FSAR. We noticed today that we have one comment from you that we haven't closed out yet. Your comment was originally transmitted via email. You wanted us to acknowledge five DP gauges that can detect ventilation upsets in the vaults. We have changed the text in the FSAR to reflect your suggested change. I transferred your comment onto an RCR form and added our disposition. The RCR is attached in WP5.1 format.

1 would appreciate it if you would respond with an email that says you agree to the comment disposition indicated in the RCR at your earliest convenience. I can use the email concurrence to close out the RCR. If you need to see that actual change made to the final document, $I$ can fax you a copy of the redlined page. Please call me at $376-3093$ if you have any questions or concerns.

<< File: HALL.RCR >

Thanks,

Brett 


\begin{tabular}{|l|l|l|}
\hline \multirow{2}{*}{ REVIEW COMMENT RECORD (RCR) } & $\begin{array}{l}\text { 1. Date } \\
1 / 8 / 99\end{array}$ & $\begin{array}{c}\text { Review No, } \\
1\end{array}$ \\
\cline { 2 - 4 } & $\begin{array}{c}\text { 3. Project No. } \\
\text { PFP FSAR }\end{array}$ & 4. Page \\
1 of 1
\end{tabular}

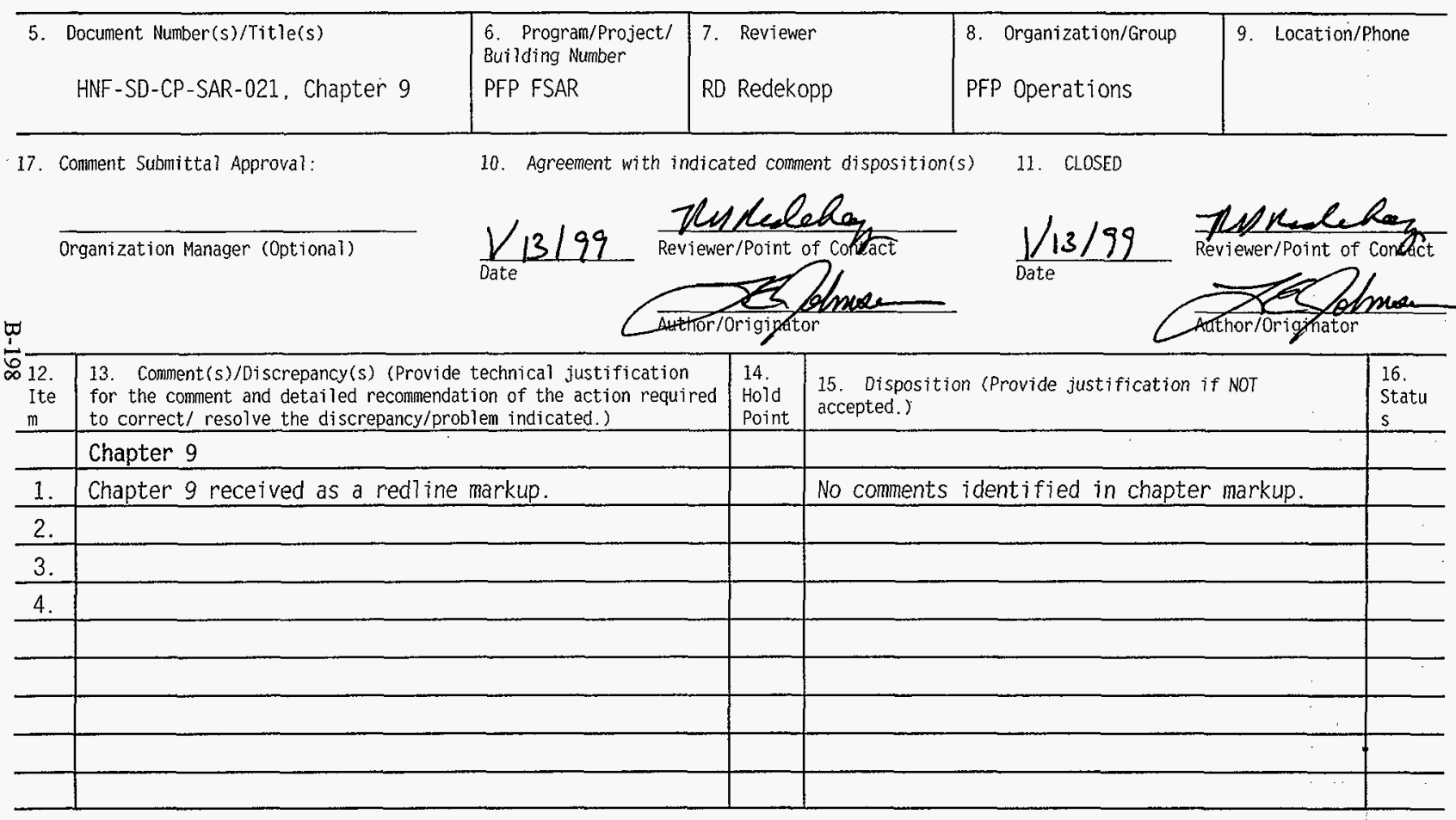




\section{REVIEW COMMENT RECORD (RCR)}

\begin{tabular}{|l|l|}
\hline $\begin{array}{l}\text { 1. Date } \\
12 / 22 / 98\end{array}$ & 2. Review Ho. \\
\hline $\begin{array}{c}\text { Project No. FSPR } \\
\text { PFP FSAR }\end{array}$ & 4. Page 1 of 1 \\
\hline
\end{tabular}

5. Document Number(s)/Title(s)

HNF-SD-CP-SAR-021, Chapter 10

17. Comment Subritital Approval:

Organization Manager (Optional)
6. Program/Project/ Building Number

PFP SAR

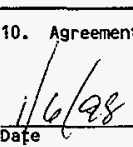

7. Reviewer

T. A. Brown

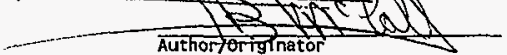

8. Organization/Group
PFP Transition
Operations

234-5Z/119/200W

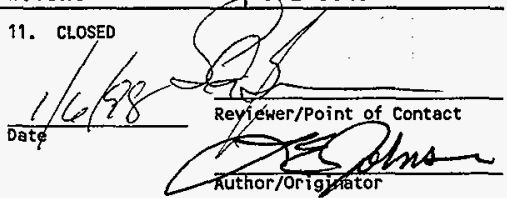

kuthor/Origjutor

\begin{tabular}{|c|c|c|c|c|}
\hline 12. & $\begin{array}{l}\text { 13. Comment(s)/Discrepancy(s) (Provide technical justification for the } \\
\text { comment and detailed recormendation of the action required to correct/ } \\
\text { resolve the discrepancy/problem indicated.) }\end{array}$ & $\begin{array}{l}\text { 14. } \\
\text { Mold } \\
\text { Point }\end{array}$ & 15. Disposition (Provide justification if NOr accepted.) & $\begin{array}{l}16 . \\
\text { status }\end{array}$ \\
\hline 1 & $\begin{array}{l}\text { Page } 10-11 \text {, Section 10.1.1.7.3: B\&W Protec is on its } \\
\text { way out. }\end{array}$ & & $\begin{array}{l}\text { REJECT FOR NOW. WE DON'T MAVE ANP } \\
\text { DOCWMENTATION YET WITH BSWP STANSE }\end{array}$ & \\
\hline & & & & \\
\hline & & & & \\
\hline & & & & \\
\hline & & & & \\
\hline & & & & \\
\hline & & & & \\
\hline & & & & \\
\hline & & & & \\
\hline & & & & \\
\hline & & & & \\
\hline & & & & \\
\hline & & & & \\
\hline & & & . & \\
\hline & & & & \\
\hline
\end{tabular}




\begin{tabular}{|l|l|l|}
\hline \multirow{2}{*}{ REVIEW COMMENT RECORD (RCR) } & 1. Date & 2. Review No. \\
\cline { 2 - 3 } & 3. Project No. & 4. Page 1 \\
\hline
\end{tabular}

\begin{tabular}{l|l|l|l|l}
\hline 5. Document Number(s)/Title(s) & $\begin{array}{l}\text { 6. Program/Project/ } \\
\text { Building Number } \\
\text { PFP }\end{array}$ & S. Reviewer Faulk & 8. Organization/Group \\
$\begin{array}{l}\text { PFP Safety Analysis Report Chapter } \\
10\end{array}$ & 9. Location/Phone \\
\hline
\end{tabular}

17. Comment Submittal Approval:

Organization Manager (Optional)

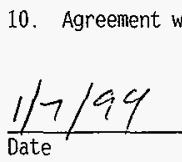

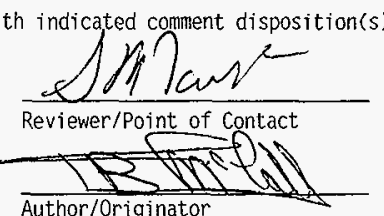

Author/Originator

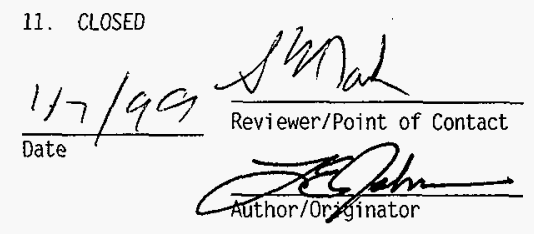

\begin{tabular}{|c|c|c|c|c|}
\hline $\begin{array}{l}12 . \\
\text { Ite } \\
\end{array}$ & $\begin{array}{l}\text { 13. Comment(s)/Discrepancy(s) (Provide technical justification } \\
\text { for the comment and detailed recommendation of the action required } \\
\text { to correct/ resolve the discrepancy/problem indicated.) }\end{array}$ & $\begin{array}{l}14 . \\
\text { Hoid } \\
\text { Point }\end{array}$ & $\begin{array}{l}\text { 15. Disposition (Provide justification if NOT } \\
\text { accepted.) }\end{array}$ & $\begin{array}{l}16 . \\
\text { Statu } \\
\text { s }\end{array}$ \\
\hline 10. & $\begin{array}{l}\text { PFP uses ZCRs now rather thath emergency response } \\
\text { guides. }\end{array}$ & & $A=A \cos P T$ & \\
\hline $\begin{array}{l}10 . \\
5.2 \\
\text { Par } \\
1\end{array}$ & $\begin{array}{l}\text { Delete "or descalation" in third sentence of first } \\
\text { paragraph. Emergencies cannot be be de-escalated. } \\
\text { only escalated or terminated. }\end{array}$ & & $A$ & \\
\hline $\begin{array}{l}10 . \\
5.2 \\
\text { Par } \\
2\end{array}$ & HNF PRO 424 is titled Emergency Preparedness Program & & $A$ & \\
\hline
\end{tabular}




\begin{tabular}{|l|l|l|l|}
\hline \multirow{2}{*}{ REVIEW COMMENT RECORD (RCR) } & $\begin{array}{l}\text { 1. Date Review No. } \\
12 / 11 / 98\end{array}$ \\
\cline { 2 - 4 } & 3. Project No. & 4. Page \\
\hline
\end{tabular}

\begin{tabular}{|c|c|c|c|c|}
\hline $\begin{array}{l}12 . \\
\text { Ite } \\
\text { m }\end{array}$ & $\begin{array}{l}\text { 13. Comment(s)/Discrepancy(s) (Provide technical justification } \\
\text { for the comment and detailed recommendation of the action required } \\
\text { to correct/ resolve the discrepancy/problem indicated.) }\end{array}$ & $\begin{array}{l}14 . \\
\text { Hoid } \\
\text { Point }\end{array}$ & $\begin{array}{l}\text { 15. Disposition (Provide justification if NOT } \\
\text { accepted.) }\end{array}$ & $\begin{array}{l}16 . \\
\text { Statu } \\
\text { S }\end{array}$ \\
\hline $\begin{array}{c}10 . \\
5.3 \\
\text { Par } \\
2\end{array}$ & $\begin{array}{l}\text { Delete reference to ECC. There has been no ECCS for } \\
\text { several years }\end{array}$ & & A & \\
\hline $\begin{array}{c}10 . \\
6 \\
\text { Par } \\
3\end{array}$ & PFP uses ZCRs, not emergency response guides & & $A$ & \\
\hline $\begin{array}{c}10 . \\
6 \\
\text { Par } \\
4\end{array}$ & $\begin{array}{l}\text { BED provides notification to POC AND ONC on } 911 . \\
\text { The ONC notifies DOE Headquarters....... } \\
\text { Delete "recommends appropriate emergency action } \\
\text { level and" } \\
\text { add "ONC" after POC. Change DOE-RL to ONC provides } \\
\text { offsite, notifications....." }\end{array}$ & & $\begin{array}{l}A \\
A\end{array}$ & \\
\hline $\begin{array}{c}10 . \\
6 \\
\text { Par } \\
4\end{array}$ & De ete paragraph 5 . There is no ECC. & & A & \\
\hline $\begin{array}{l}10 . \\
6.1\end{array}$ & $\begin{array}{l}\text { This section is extremely out of date and provides } \\
\text { descriptions of centers and functions that do not } \\
\text { exist, doesn't describe contractor funtion in RL EOC } \\
\text { and does not describe incident response via ICS. } \\
\text { Recommend total rewrite of this section from 10.6.1 } \\
\text { to } 10.6 .1 .3 \text { using DOE RL } 94-02 \text { Section 2.2. }\end{array}$ & & $\begin{array}{l}\text { AOCEPT. WILL BE REVISED TO } \\
\text { NCLUDE SECTIONS FROM } 2.2 \mathrm{~N} \\
\text { DOE-RL- } 94-02 \text { AS AGREED IN } \\
\text { TELECON ON } 1 / 6 / 99\end{array}$ & . \\
\hline
\end{tabular}




\begin{tabular}{|l|l|l|l|}
\hline REVIEW COMMENT RECORD (RCR) & $\begin{array}{l}\text { Date Review No. } \\
12 / 11 / 98\end{array}$ \\
\cline { 2 - 3 } & 3. Project No. & 4. Page \\
\hline
\end{tabular}

\begin{tabular}{|c|c|c|c|c|}
\hline $\begin{array}{l}12 . \\
\text { Ite } \\
\text { m }\end{array}$ & $\begin{array}{l}\text { 13. Comment(s)/Discrepancy(s) (Provide technical justification } \\
\text { for the comment and detailed recommendation of the action required } \\
\text { to correct/ resolve the discrepancy/problem indicated.) }\end{array}$ & $\begin{array}{l}\text { Hold } \\
\text { Hoint }\end{array}$ & $\begin{array}{l}\text { 15. Disposition (Provide justification if NOT } \\
\text { accepted.) }\end{array}$ & $\begin{array}{l}16 . \\
\text { Statu } \\
\text { s }\end{array}$ \\
\hline $\begin{array}{l}10 . \\
6.2\end{array}$ & Delete second sentence. There is no ECC & & A & \\
\hline $\begin{array}{l}10 \\
6.4 \\
.2\end{array}$ & $\begin{array}{l}\text { Is the portable whole body counter still in } 200 \text { East } \\
\text { Area? Need to check. }\end{array}$ & & $\begin{array}{l}\text { A The WEC IS AT THE } 747 \mathrm{~A} \\
\text { BUILDINS IN RISH2AND AS } \\
\text { =TATEN IN } 10.6 .4 .10 \%\end{array}$ & \\
\hline $\begin{array}{l}10 . \\
6.4 \\
.3 . \\
2 \\
\end{array}$ & Delete. There is no ECC & & $A$ & \\
\hline $\begin{array}{c}10 . \\
6.4 \\
.3 . \\
3\end{array}$ & $\begin{array}{l}\text { Second Bullet should read"A conferencing bridge to } \\
\text { provide communications between the incident command } \\
\text { post and the RL-EOC." }\end{array}$ & & $A$ & \\
\hline $\begin{array}{l}10 \\
6.5 \\
\operatorname{Par} \\
3\end{array}$ & Delete. Incorrect and redundant & & $\begin{array}{l}\text { Accept. Parngraph beginning "IF an } \\
\text { EVENT..." will be deletad }\end{array}$ & \\
\hline $\begin{array}{l}10 \\
6.6 \\
.1\end{array}$ & Delete reference to ECC & & A & \\
\hline
\end{tabular}




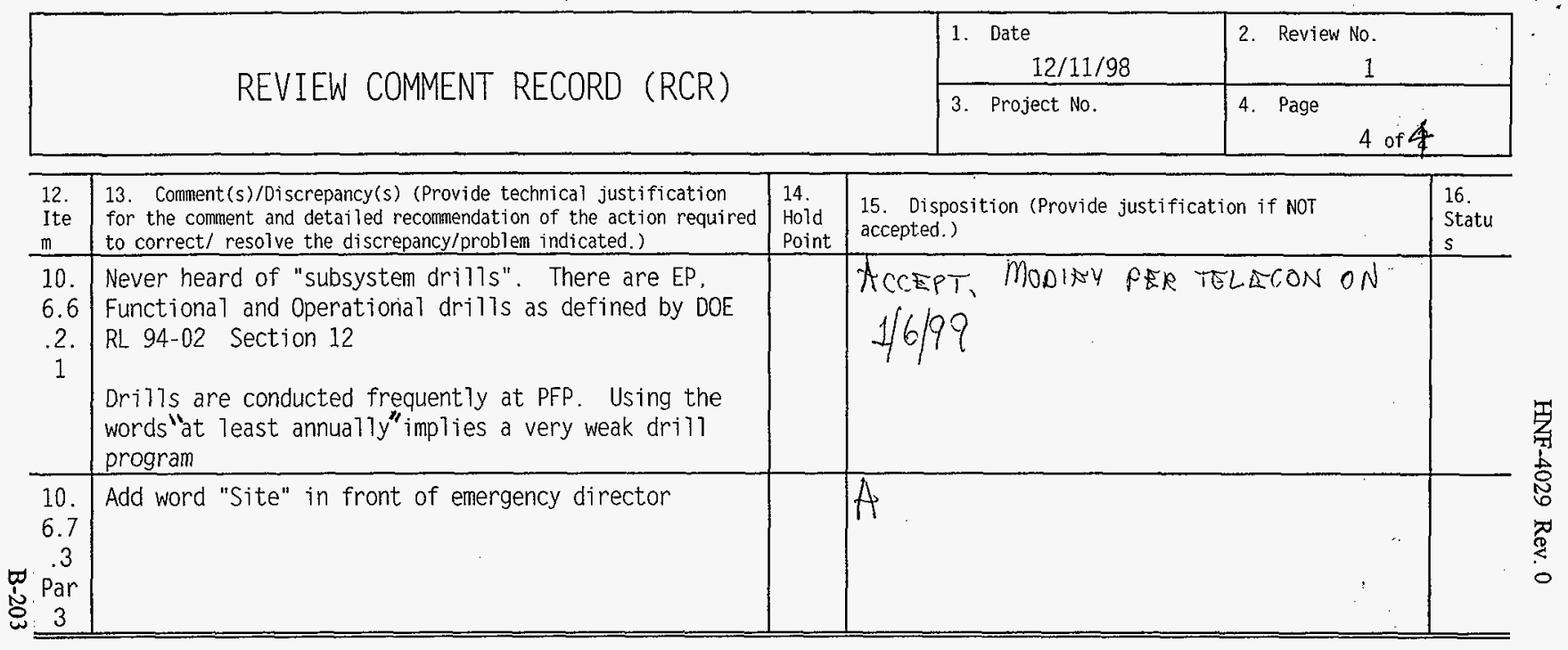


REVIEW COMMENT RECORD (RCR)

\begin{tabular}{|l|l|}
\hline $\begin{array}{l}\text { 1. Date } \\
12 / 17 / 98\end{array}$ & 2. Review No. \\
\hline $\begin{array}{c}\text { 3. Project No. } \\
\text { PFP SAR }\end{array}$ & 4. Page \\
\hline
\end{tabular}

5. Document Number(s)/Title(s)

HNF-SD-CP-SAR-021, Chapter 10
6. Program/Project/ Building Number PFP SAR
7. Reviewer
D. R. Groth

8. Organization/Group
PFP. Quality
Assurance

11. CLOSED

10. Agreenent with indicgted compent disposition(s)

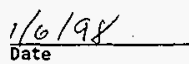
Revierfor point oul contact ijugted

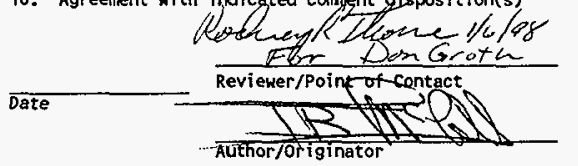

Date Aüchor/originator
Date
9. Location/Phone

MO 017//200W 373-5029
17. Comnent Submittal Approval:

Organization Manager (Optional)
15. Disposition (Provide justification if NOT accepted.) Hold 13. Comment(s)/Discrepancy(s) (Provide technical justification for the corment and detai led recommendation of the
resolve the discrepancy/problem indicated.)

1.

Replace "Babcock \& Wilcox Hanford Company" with "B\&W Hanford Company" in Section 10.1.1, page RIO-1 (nine references) and perhaps other places (suggest a word search). I had just recently forwarded a note from Diana Grando on that.

2. Replace "Enterprize" with Enterprise" in Sections 10.1.1.7, 10.1.7.3 and perhaps other places.

3. Page R10-2 lists $\mathrm{HHC}-\mathrm{CM}-4-14$. This was canceled long ago and I can't find it Tisted in the text, though it is in Table T10-1. ESP-PEP-5-8 appears many places (as WHC-CM-5-8), but is not listed in Table T10-1.

4. Table 10-1: You are aTready aware that the list includes numerous references to WHC-CM-5-8 and other documents which have changed to the FSP-PFP-prefix. No need for me to identify them all.

\begin{tabular}{|l|ll|l|l}
\hline $\begin{array}{l}14 . \\
\text { Hoid } \\
\text { Point }\end{array}$ & 15. Disposition (Provide justification if Nor accepted.) & $\begin{array}{l}16 . \\
\text { Status }\end{array}$ \\
\hline & Accept. & $\vdots$ & \\
\hline & Accept. & & \\
\hline & Accept. & & \\
\hline & Accept. & & \\
\hline
\end{tabular}




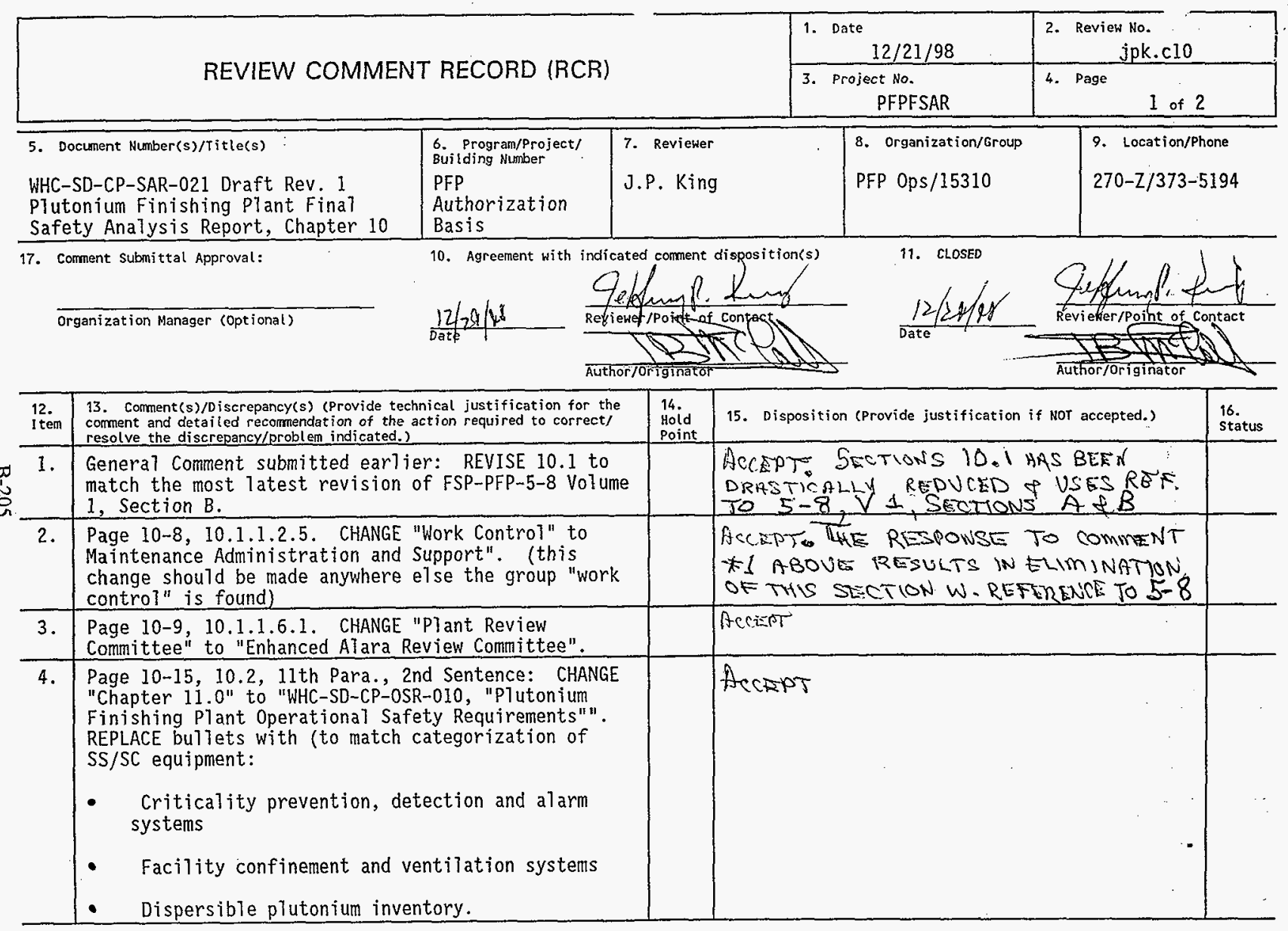




\begin{tabular}{|c|c|c|}
\hline & $\begin{array}{l}\text { 1. Date } \\
12 / 21 / 98\end{array}$ & $\begin{array}{l}\text { 2. Revien No. } \\
\text { jpk.clo }\end{array}$ \\
\hline REVIEVV LORIVIEN I RELUKD (RCR) & $\begin{array}{l}\text { 3. Project No. } \\
\text { PFPFSAR }\end{array}$ & 4. Page \\
\hline
\end{tabular}

\begin{tabular}{|c|c|c|c|c|}
\hline $\begin{array}{l}12 . \\
\text { Item }\end{array}$ & $\begin{array}{l}\text { 13. Comment(s)/Discrepancy(s) (Provide technical justification for the } \\
\text { corment and detai ied recommendation of the action required to correct/ } \\
\text { resolve the diserepancy/problem indicated, }\end{array}$ & $\begin{array}{l}14 . \\
\text { Hoid } \\
\text { Point }\end{array}$ & 15. Disposition (Provide justification if Nor accepted.) & $\begin{array}{l}\text { 16. } \\
\text { status }\end{array}$ \\
\hline 5. & Page $10-19,10.4 .3:$ See comment $\# 2$ above. & & Acosin & \\
\hline 6. & $\begin{array}{l}\text { Pages T10-6 through T10-18: CHANGE al1 WHC-CM-5-8 } \\
\text { references to FSP-PFP-5-8. CHANGE all WHC-IP-082I- } \\
\text { PU0 references to HNF-IP-0821 }\end{array}$ & & $\begin{array}{l}\text { Accepr. ThBls's will be reploced by } \\
\text { referencing }\end{array}$ & \\
\hline & & & & \\
\hline & & & & \\
\hline & & & & \\
\hline & . & & & \\
\hline
\end{tabular}

ஸ્. 


\section{REVIEW COMMENT RECORD (RCR)}

\begin{tabular}{|l|l|}
\hline $\begin{array}{l}\text { 1. Date } 12 / 21 / 98 \\
\text { 2. Review No. }\end{array}$ \\
\hline $\begin{array}{l}\text { Project No. } \\
\text { PFP FSPR }\end{array}$ & 4. Page \\
\hline
\end{tabular}

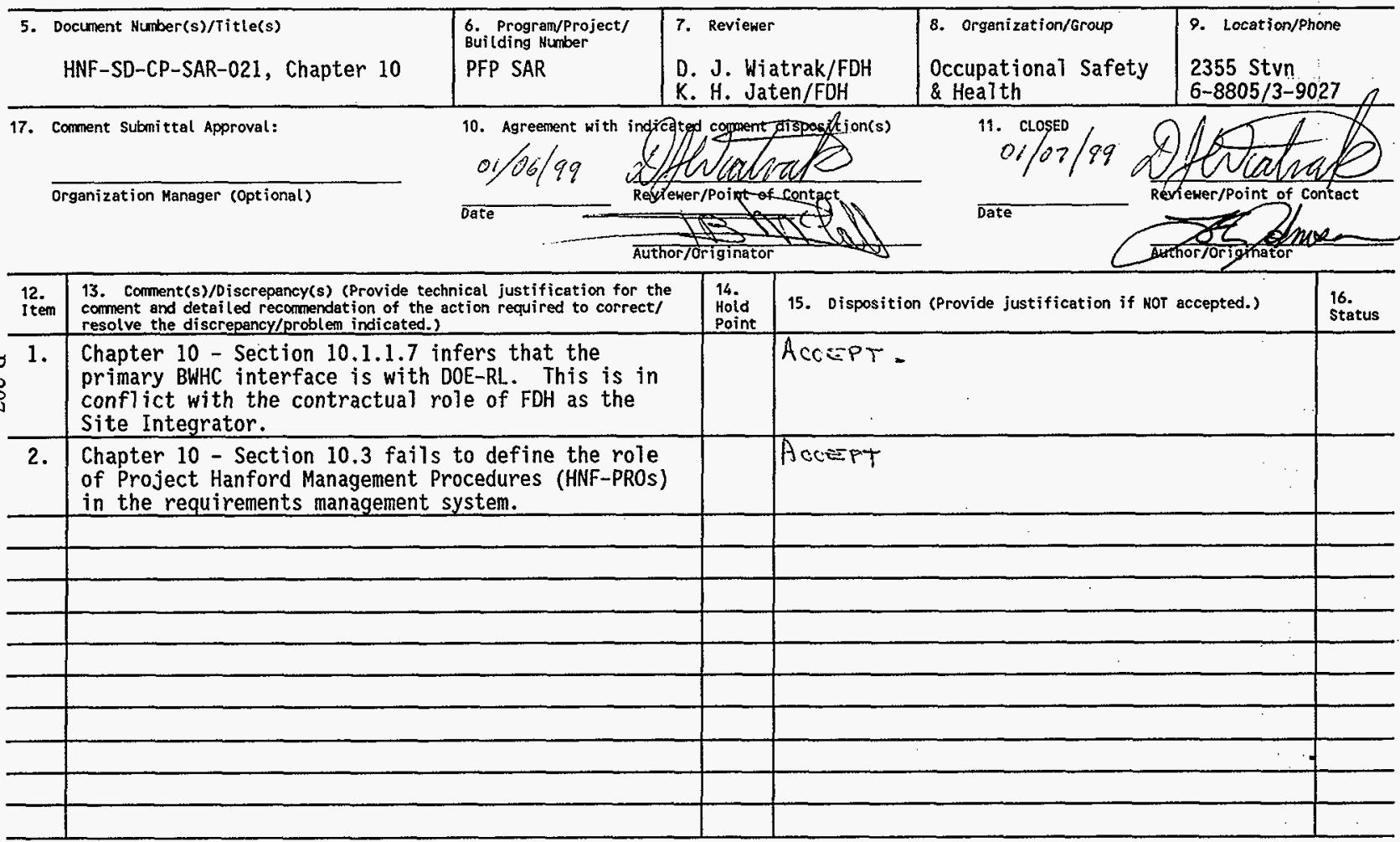




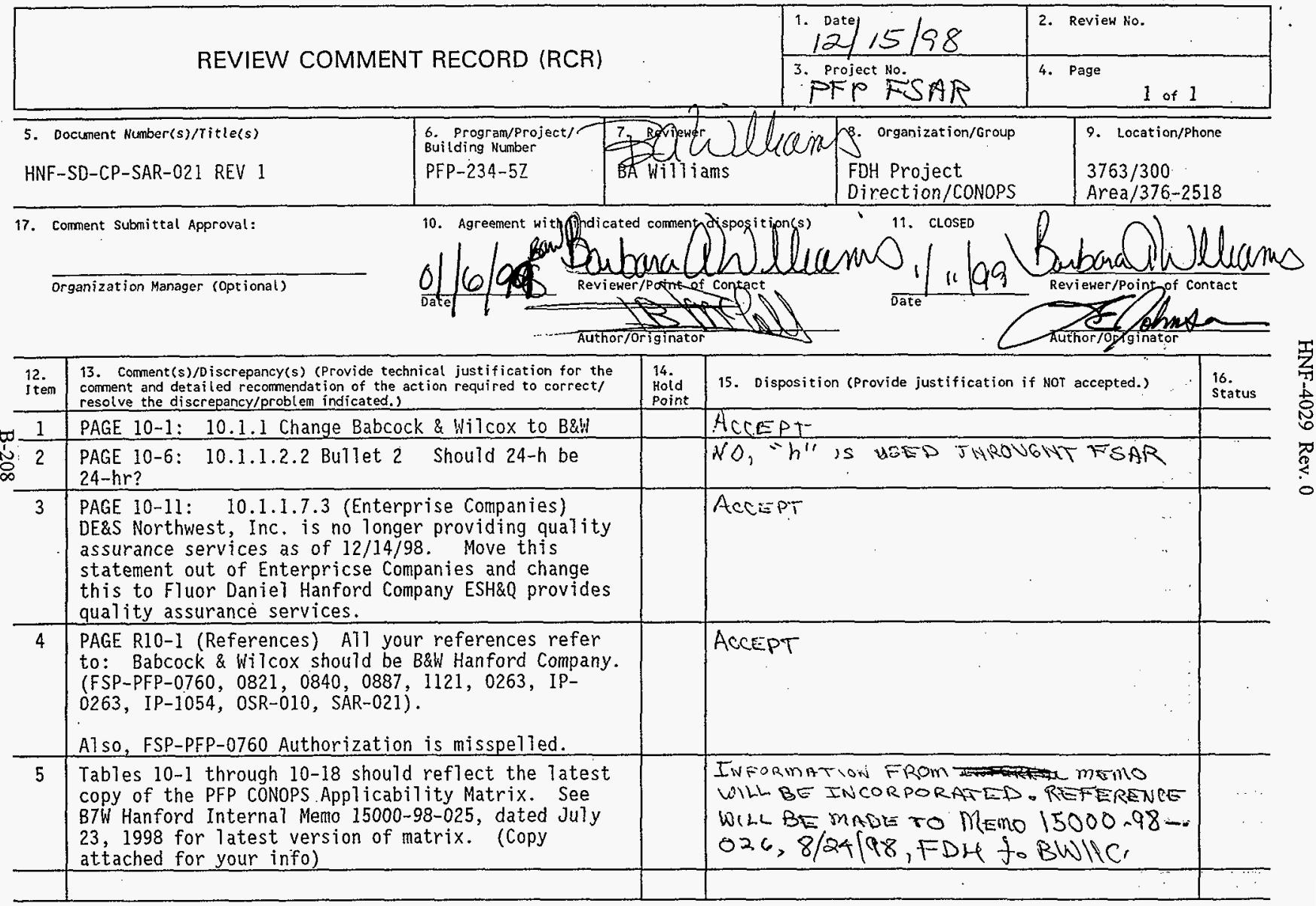




\section{REVIEW COMMENT RECORD (RCR)}

\begin{tabular}{|l|l|}
\hline 1. Date $12 / 18 / 98$ & 2. Review No. \\
\hline $\begin{array}{l}\text { 3. Project No. } \\
\text { PFP KSAR }\end{array}$ & 4. Page 1 of 1 \\
\hline
\end{tabular}

5. Document Number(s)/ritle(s)

HNF-SD-CP-SAR-021, Chapter 10

17. Comment Submittal Approval:

Organization Manager (Optional)

6. Program/Project/ Building Number PFP SAR

10. Agreenent with indicated coment disposition(s)

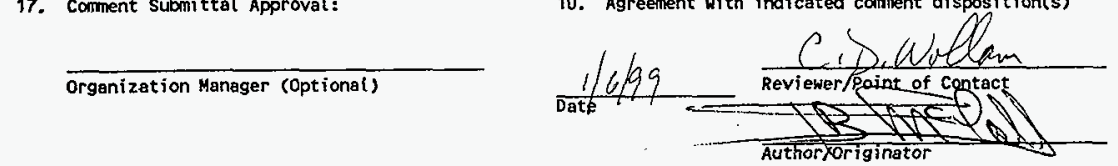

8. Organization/Group

Technical Integration
9. Location/Phone

2753E/B104/200E $373-1587$

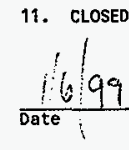

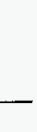

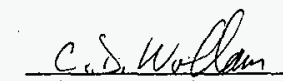

Reviewer/Point of contact

\begin{tabular}{|c|c|}
\hline $\begin{array}{l}12 . \\
\text { Item }\end{array}$ & $\begin{array}{l}\text { 13. Comment(s)/Discrepancy(s) (Provide technical justification for } t \\
\text { comment and detailed recormendation of the action required to correct } \\
\text { resolve the discrepancy/problem indicated.) }\end{array}$ \\
\hline 1 & $\begin{array}{l}\text { KEY ITEM: } 10.1 .1 .7 .3 \text { "QA by DESNW", Their contrac } \\
\text { runs out in } 12 \text { days, FDH will absorb those } \\
\text { functions. }\end{array}$ \\
\hline 2. & $\begin{array}{l}\text { Table } 10.1 \text { Are you still using WHC implementing } \\
\text { procedures? }\end{array}$ \\
\hline
\end{tabular}

\begin{tabular}{|l|l|l|l}
\hline $\begin{array}{l}14 . \\
\text { Hold } \\
\text { Point }\end{array}$ \\
\hline
\end{tabular}

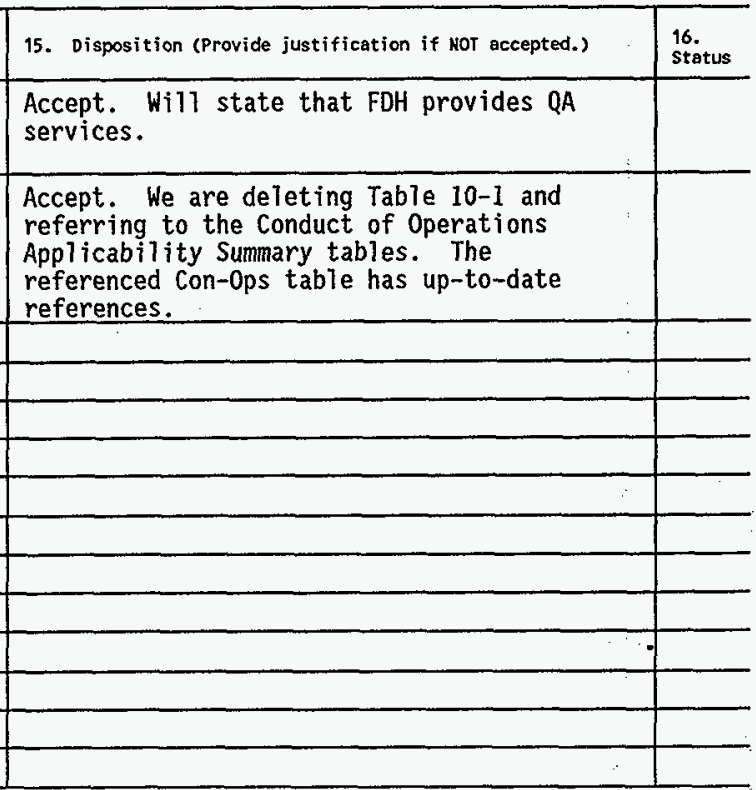




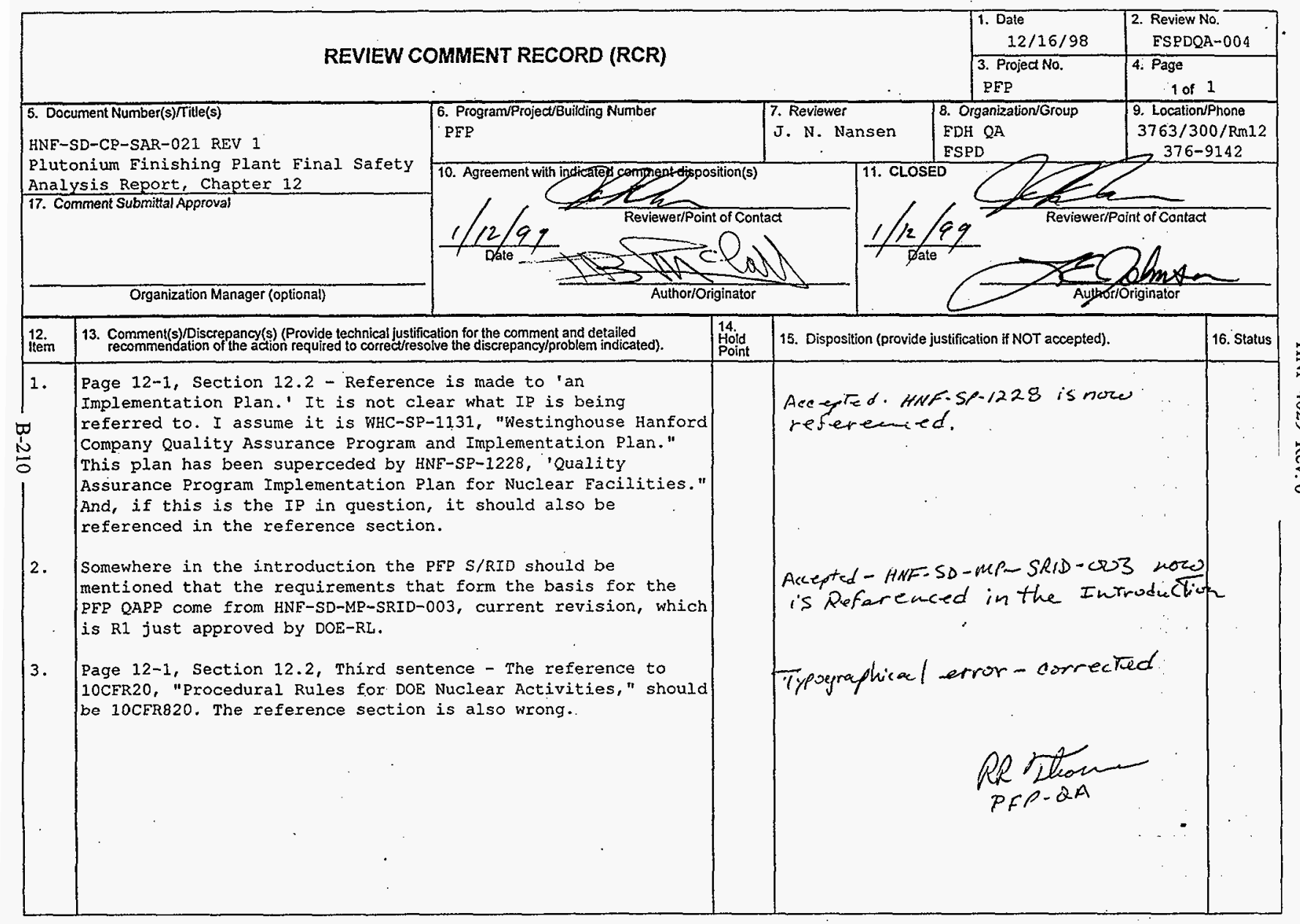




\section{REVIEW COMMENT RECORD (RCR)}

\begin{tabular}{l} 
1. Date $12 / 21 / 98 \mathrm{P}$ \\
\hline
\end{tabular}

3. Project No. PFP FSAR
5. Document Number(s)/Title(s)

HNF-SD-CP-SAR-021, Chapter 12
6. Program/Project/ Building Number PFP SAR

\section{Reviewer}

R. D. Redekopp
8. Organization/Group

PFP Operations
2. Review Ho.

4. Page

1 of 1

9. Location/Phone

234-5Z/117/200W 373-3539

10. Agreement with indicated comment disposition(s)

17. Comment Submittal Approval:

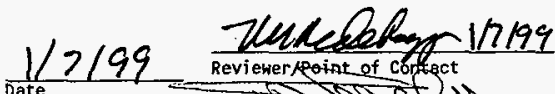
Organization Manager (Optional)

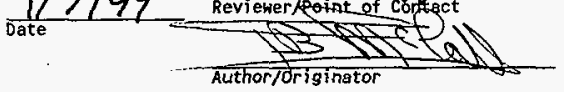

\section{$1 / 12 / 99$}

Mntedebor Reviewer/Point of Cont $6 t$ 21 Author/orignator

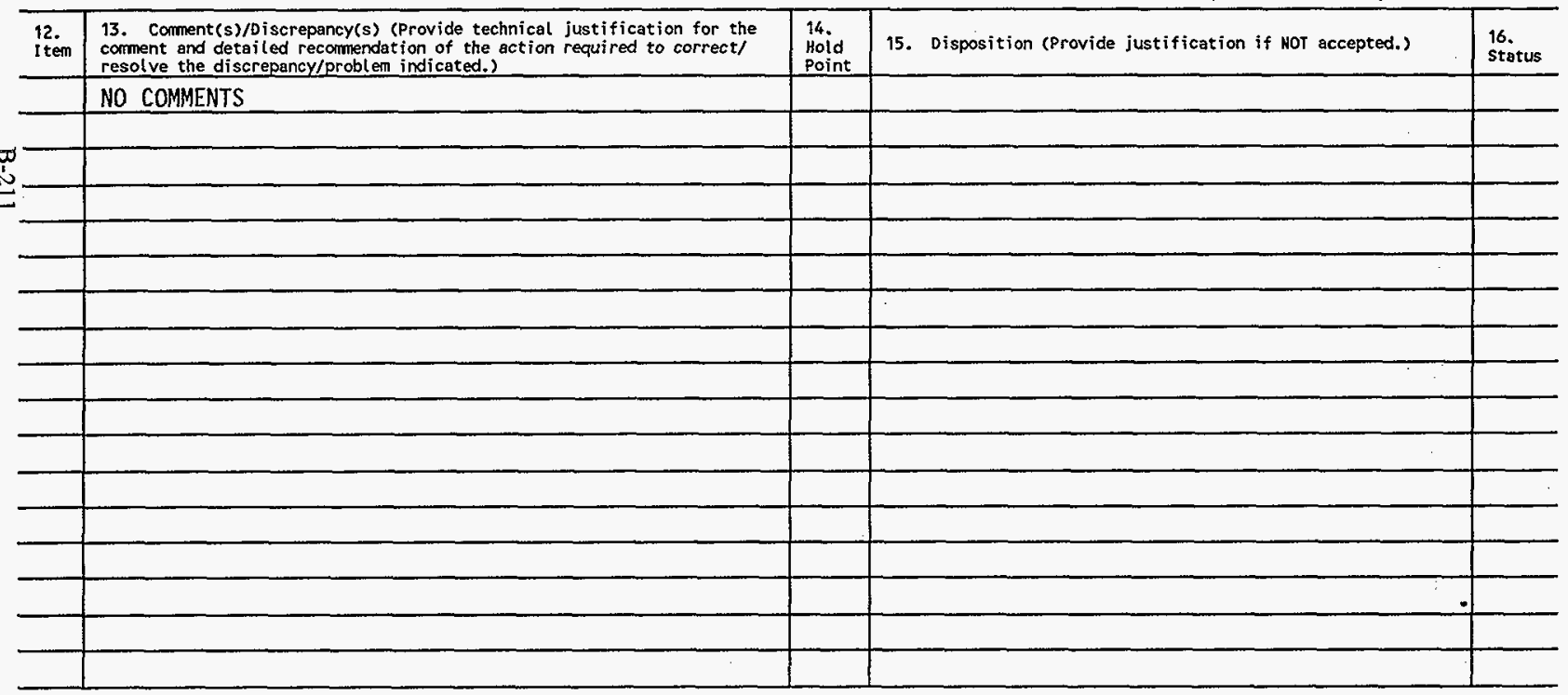




\section{REVIEW COMMENT RECORD (RCR)}

\begin{tabular}{|c|l|}
\hline $\begin{array}{l}\text { 1. Date } \\
12 / 22 / 98\end{array}$ & 2. Review No. \\
\hline $\begin{array}{c}\text { 3. Project No. } \\
\text { PFP FSAR }\end{array}$ & 4. Page \\
\hline
\end{tabular}

5. Document Number(s)/Title(s)

HNF-SD-CP-SAR-021, Chapter 12

\begin{tabular}{l|l}
$\begin{array}{l}\text { 6. Program/Project/ } \\
\text { Building Number } \\
\text { PFP SAR }\end{array}$ & 7. Reviewer \\
C. D. Woll am
\end{tabular}

10. Agreenent with indicated comment disposition(s)

17. Coment Submittal Approval:

Organization Manager (optional)
8. Organization/Group

Technical

Integration
9. Location/Phone

$2753 \mathrm{E} / \mathrm{B} 104 / 200 \mathrm{E}$ 373-1587

11. CLOSED

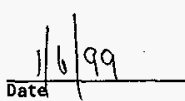

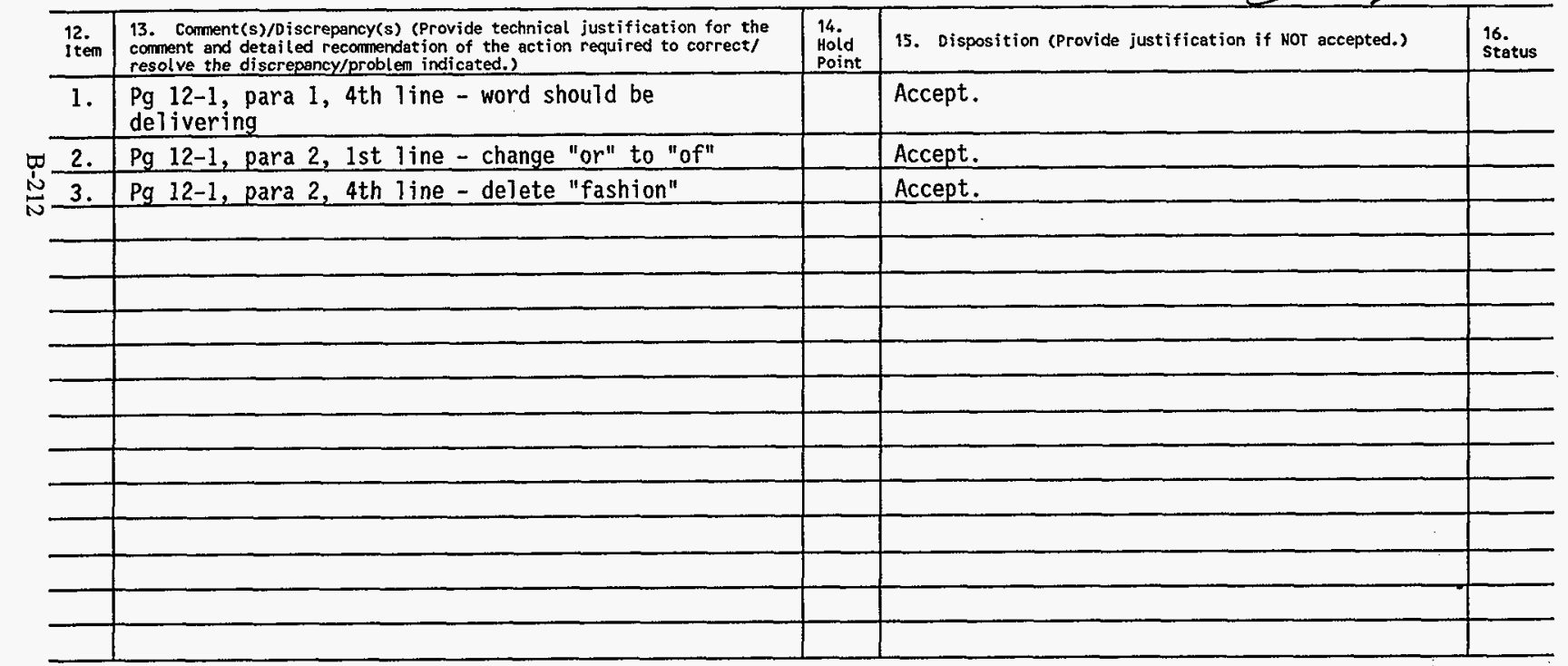


HNF-4029 Rev. 0

Appendix C

PFP FSAR Review Schedule

C-1 
HNF-4029 Rev. 0

This page intentionally left blank. 
PFP FSAR REVIEW SCHEDULE

\begin{tabular}{|c|l|c|c|c|c|}
\hline Chapter \# & \multicolumn{1}{|c|}{ Chapter Title } & $\begin{array}{c}\text { Release Date for } \\
\text { Functional Review }\end{array}$ & $\begin{array}{c}\text { Package \# } \\
\text { Review } \\
\text { Comment Due } \\
\text { Date }\end{array}$ & $\begin{array}{c}\text { Review Period } \\
\text { (Calendar } \\
\text { days) }\end{array}$ \\
\hline 1 & Introduction and General Plant Description & $12 / 16$ & 4 & $12 / 21$ \\
\hline 2 & Summary Safety Assessment & $12 / 18$ & 5 & $12 / 21$ \\
\hline 3 & Site Characteristics & $12 / 9$ & 1 & $12 / 21$ \\
\hline 4 & Principle Design Criteria & $12 / 11$ & 2 & $12 / 21$ \\
\hline 5 & Plant Description & $12 / 14^{(2)}$ & 3 & $12 / 21$ & 10 \\
\hline 6 & Process Systems & $12 / 16^{(3)}$ & $5 \mathrm{a}$ & $12 / 21$ & 5 \\
\hline 7 & Waste Confinement and Management & $12 / 14$ & 3 & $12 / 21$ \\
\hline 8 & Radiation Protection & $12 / 14$ & 3 & $12 / 21$ \\
\hline 9 & Accident Safety Analysis & $12 / 18^{(1)}$ & $4 \& 5$ & $12 / 21$ \\
\hline 10 & Conduct of Operations & $12 / 11$ & 2 & $12 / 21$ \\
\hline 12 & Quality Assurance & $12 / 9$ & 1 & $12 / 21$ \\
\hline
\end{tabular}

(1) Completed pieces of the new analysis were provided on $12 / 17$ for SRB review. The assembled chapter was provided on $12 / 18$.

(2) Delivery for functional review was delayed until $12 / 17$

(3) Delivery for functional review was delayed until $12 / 19$ 
HNF-4029 Rev. 0

This page intentionally left blank. 


\section{DISTRIBUTION SHEET}

To

Distribution

Plutonium Finishing Plant Final Safety Analysis Report Functional, Safety Review Board, and Fluor Daniel Hanford Review Report

\begin{tabular}{|c|c|c|c|c|c|}
\hline Name & MSIN & $\begin{array}{c}\text { Text } \\
\text { With All } \\
\text { Attach. }\end{array}$ & Text Only & $\begin{array}{l}\text { Attach I } \\
\text { Appendix } \\
\text { Only }\end{array}$ & $\begin{array}{c}\text { EDT/ECN } \\
\text { Only }\end{array}$ \\
\hline s. C. Adams & L5-65 & $\mathrm{x}$ & & & \\
\hline E. G. Backlund & T5-54 & $\mathrm{x}$ & & & \\
\hline B. I. BaumanN & H6-34 & $\mathrm{x}$ & & & \\
\hline J. E. Bramson & T5-54 & $\mathrm{x}$ & & & \\
\hline T. A. Brown & T5-15 & $\mathrm{x}$ & & & \\
\hline H. M. Bucci & $\mathrm{H} 6-32$ & $\mathrm{x}$ & & & \\
\hline K. K. Chitkara & L5-65 & $\mathrm{x}$ & & & \\
\hline D. A. Conners IV & T5-11 & $\mathrm{x}$ & & & \\
\hline E. W. Curfman & T5-05 & $x$ & & & \\
\hline J. D. Dick & $\mathrm{T} 4-20$ & $\mathrm{x}$ & & & \\
\hline J. S. Dukelow Jr. & $\mathrm{K} 8-37$ & $\mathrm{x}$ & & & \\
\hline S. M. Faulk & $\mathrm{L} 4-14$ & $\mathrm{x}$ & & & \\
\hline D. R. Groth & $\mathrm{T} 4-15$ & $\mathrm{x}$ & & & \\
\hline A. M. Horner & L6-57 & & & & $x$ \\
\hline K. H. Jaten & H6-32 & $x$ & & & \\
\hline L. E. Johnson & $B 4-46$ & & & & $\mathrm{X}$ \\
\hline R. D. Keck & $\mathrm{T} 4-20$ & $\mathrm{x}$ & & & \\
\hline J. P. King & T5-5I & $\mathrm{x}$ & & & \\
\hline D. S. Leach & $\mathrm{B} 4-45$ & & & & $x$ \\
\hline J. N. Nansen & L5-65 & $\mathrm{x}$ & & & \\
\hline S. E. Nunn & T5-11 & $\mathrm{x}$ & & & \\
\hline K. A. Peterson & $\mathrm{H} 6-23$ & & & & $\mathrm{x}$ \\
\hline R. D. Pickett & $\mathrm{T} 4-20$ & $\mathrm{x}$ & & & \\
\hline P. R. Prevo & N2-57 & & & & $\mathrm{x}$ \\
\hline A. L. Ramble & T5-54 & $\mathrm{x}$ & & & \\
\hline R. D. Redekopp & T5-15 & $x$ & & & \\
\hline D. G. Ranade & H6-23 & & & & $\mathrm{x}$ \\
\hline G. Rippy & T5-50 & & & & $x$ \\
\hline H. R. Risenmay & $\mathrm{T} 5-55$ & $\mathrm{x}$ & & & \\
\hline P. E. Roege & T5-50 & $x$ & & & \\
\hline F. A. Ruck & H6-23 & & & & $\mathrm{x}$ \\
\hline J. E. Shapley & B4-46 & & & & $\mathrm{x}$ \\
\hline
\end{tabular}

From

A. L. Ramble

A. I. Ramble

\section{Project Title Work Order}

Safety Review Board, and 


\section{DISTRIBUTION SHEET}

To

Distribution

Project Title/Work Order

Plutonium Finishing Plant Final Safety Analysis Report Functional, Safety Review Board, and Fluor Daniel Hanford Review Report

\section{Name}

\section{D. Talbot}

W. F. White

D. J. Wiatrak

B. A. Williams

C. D. Wollam

s. Zeller
From

A. L. Ramble
Page 2 of 2
Date $2 / 17 / 99$

EDT No. 619973

ECN No. N/A

\begin{tabular}{|l|l|c|c|}
\hline $\begin{array}{c}\text { Text } \\
\text { With All } \\
\text { Attach. }\end{array}$ & Text Only & $\begin{array}{c}\text { Attach.l } \\
\text { Appendix } \\
\text { Only }\end{array}$ & $\begin{array}{c}\text { EDT/ECN } \\
\text { Only }\end{array}$ \\
\hline
\end{tabular}

